\title{
WATER-POWER RESOURCES OF THE UMPQUA RIVER AND ITS TRIBUTARIES, OREGON
}

\author{
By Benjamin E. Jones and Harold T. Stearns
}

\section{PREFACE}

The following observations were made by the Secretary of the Interior in his report to the President for the fiscal year ended June 30, 1928:

The new business policy for administering the national domain began to take shape about 20 years ago, but its evolution continues. Its keynote has been to put to the best possible use whatever remains in public ownershipwise utilization of land, whether agricultural or mineral, grazing or irrigable, forest or power site. Such a policy predicates scientific land classification. * * * The laws providing for leasing lands that are chiefly valuable for the mining of coal, oil, gas, phosphate, or potash or the generating of water power likewise recognize scientific classification of the Nation's lands as an integral part of public-land administration. At its start, half a century ago, the land classification was necessarily of the nature of a general and qualitative survey of the national domain, but the Interior Department engineers have been putting their investigations on a more and more detailed and exact basis, until now they seek to afford a quantitative determination of every natural resource that gives value to the publicly owned lands. Only with the facts at hand as to the relative worth and possible use of these lands is it possible to administer properly. the land laws of to-day and to propose more advanced laws for to-morrow.

Foremost among the present-day activities of the Government in planning for the future is its handling of the resources that represent the energy supply. A national inventory of tons of coal, barrels of oil, and second-feet of water is a measure of the potential aid that will be ready for American workers of the future. With the present realization that the limit to be placed on industrial progress is likely to be fixed by the amount of power available for doing man's work, it is a plain duty to safeguard the future with a business-like policy in developing these stores of oil and coal and in utilizing these power sites.

An indication of the extent to which use is now being made of the water power and mineral resources under permit or lease from the Government is furnished by the following statements:

Out of a total of more than $13,000,000$ horsepower of water power now developed in the United States, more than 4,500,000 horsepower is developed on public lands or navigable streams and is being oper- 
ated under authorization of the Federal Government. From the passage of the mineral leasing law in 1920 until June 30, 1928, $197,000,000$ barrels of oil have been produced from public lands under Government lease or permit, of which more than $23,000,000$ barrels were produced during the fiscal year ending June 30, 1928. During the same period nearly $13,000,000$ tons of coal were mined from leased public lands, of which about $3,000,000$ tons were produced in the fiscal year ended June 30, 1928.

One of the chief uses of water is for the generation of power, and this use involves the lands adjacent to the stream. Public lands that would be used in the development of the water-power resources are therefore classified as power-site lands. Lands classified in this way are either retained wholly in Federal ownership, if early development seems probable, or they may be opened to entry under the homestead and other settlement laws and the surface title disposed of, the right being reserved to the Federal Government or its permittees or licensees to use the land for development of power upon payment for damages to improvements.

The power-site value of each individual tract of public land depends upon the use that would be made of that tract if the river system were developed as a whole in an efficient and economical manner. Scientific classification of any tract of land with respect to power therefore requires a study of the river as a whole, including the tributaries, and the formulation of a comprehensive plan of development.

Such studies are regularly made by the United States Geological Survey in its task of making an inventory of the water resources of the public lands, but much basic work must be done before such studies can be made intelligently and adequate plans of development can be formulated. Gaging stations to measure the stream flow must be established and maintained for a period of years and river surveys and maps must be made.

In the light of information so obtained an outline of a comprehensive plan of development for the whole stream is prepared, and later the suggested plan can be perfected by detailed field work, such as the selection, engineering, and geologic examination and survey of dam sites, reservoirs, and other critical features.

A plan for development, which may include one or more alternative schemes is then formally outlined in a report that is essentially a compilation and study of all the data previously collected. On the basis of such reports the public lands are classified as to their probable use for power, whether for conduits, reservoirs, dams, power houses, or other possible uses, all practicable alternative schemes of development being taken into consideration. Though any 
plan of development proposed must be regarded as tentative in detail and subject to modification in the light of further and more intensive studies made as a preliminary to construction, such a tentative plan can be used with assurance as a basis for estimating the potential power of the river, for locating the principal concentrations of potential power, and for guiding further studies undertaken for the purposes of actual development.

In connection with the classification of the public lands a number of reports have been prepared by the Geological Survey, outlining schemes of development for certain rivers, and though intended primarily for official use, it has seemed advisable to make many of them available for general public use.

In general, these reports contain information on geography, geology, physiography, water supply, river control, water-power sites, and market for power.

In these reports the conditions in the whole river basin are considered under geography, geology, and physiography. The same subjects are treated more in detail in the description of the individual power sites. Under water supply the records of run-off for the river and tributaries are summarized and analyzed. Under river control reservoir sites are described, capacity curves are drawn, and the effect of storage on stream flow is estimated. A summary is prepared, showing the additional horsepower that can be developed through storage and the benefits to irrigation, navigation, and flood protection. Developed water-power sites are described only briefly. In manuscript reports undeveloped sites are described in detail if they are of sufficient importance to justify it, and in published reports this information is summarized. The water supply with and without storage for 50 and 90 per cent of the time is stated, and pondage is discussed.

A feasible method of development is outlined, the head available is estimated, and the horsepower available 50 and 90 per cent of the time is computed by using the formula $\mathrm{HP}=0.08 \mathrm{QH}$, in which $\mathrm{Q}$ is the discharge in second-feet and $\mathbf{H}$ is the static head in feet. This formula is based on an average over-all efficiency of 70 per cent. The market for electric power is discussed very briefly. The distances to the nearest large cities are usually given, and some reference is made to the companies supplying the market at the time of the preparation of the report. A detailed study of rates, competition, and probable earning capacity is not attempted. The reports may also contain recommendations, which usually refer to the best.use of the government lands involved and to questions of interference between power and other uses of the water. Tables and curves used in analyzing the water supply and computations are given in the appendix to 
manuscript reports but usually are not published. Funds are available for the publication of only a small number of reports yearly. For this reason the policy of the Geological Survey is to publish only a few general reports and brief summaries of smaller reports. The results of reconnaissance river surveys are not published, but white prints of the maps are included in the power reports on the area surveyed and can be supplied at cost to anyone interested.

At present about 17,000 miles of river courses have been surveyed by the Geological Survey, and maps of many dam sites and reservoir sites are on file in the office at Washington. Most of these surveys are listed in Water-Supply Paper 558, "Preliminary index to river surveys." In addition to the river surveys the standard topographic maps are of great value in studying reservoir possibilities, drainage areas, possible diversions from one drainage basin to another, and other features relating to power. From 1895 to 1928, roughly, 32,000 station-years of stream-flow records were obtained. The Geological Survey has published 44 reports on water power and river surveys and its files contain several hundred manuscript reports, of which about 40 are open to public inspection.

This report on the water-power resources of the Umpqua River, Oreg., is representative of the reports prepared in connection with the classification of the public lands. The plan of development outlined is believed to be feasible, and it shows the potential power of the stream. Probably in the actual development of the power resources there will be considerable departures from the plan here presented, but this plan and the estimates based on it may be used as a basis to determine how much power, if any, is sacrificed by any alternative plan which may be proposed as financially preferable.

Topographic maps of the main river, with detailed maps of proposed dam sites, have been made by C. W. H. Nessler, C. P. McKinley, and R. B. Kilgore, of the topographic branch, and R. O. Helland, of the conservation branch. Geologic examinations were made at many sites by H. T. Stearns, who spent about one month in the field during the summer of 1926. Gaging stations to determine the discharge of the rivers have been maintained by the waterresources branch under F. F. Henshaw and G. H. Canfield, district engineers, at a number of stations listed elsewhere in this report. Many miscellaneous stream-flow measurements have been obtained, and several temporary gaging stations were maintained during the low-water period of 1924. A field examination of the river basin, with more detailed examinations of the different sites, was made by B. E. Jones and R. O. Helland during a period of about five months in 1924 and 1926. All the data gathered in these ways have been combined and studied to determine a feasible method of developing 
the power resources of the basin, and the results are given in this report.

The California-Oregon Power Co. has cooperated by paying the cost of maintaining certain gaging stations and by making available the logs of drill cores obtained at Rock Creek and Boundary dam sites. Previous reports on the water power of the Umpqua River by E. C. LaRue, formerly hydraulic engineer of the United States Geological Survey, and Leonard Lundgren, district engineer of the United States Forest Service, and the recommendations of F. F. Henshaw, formerly district engineer of the United States Geological Survey, have been drawn upon in the preparation of this report.

The following maps, published and for sale by the United States Geological Survey, show the topography of most of the areas covered by this report and will be valuable in any detailed study of the power projects outlined. They are priced at 10 cents a sheet.

Plan and profile of Umpqua River above Scottsburg, North Umpqua River and tributaries, in 5 plan sheets (see key map on pl. 15) and 4 profile sheets.

Miscellaneous reservoir and dam sites, Umpqua River above Scottsburg, North Umpqua River and tributaries, in 7 sheets.

Diamond Lake, Riddle, and Roseburg topographic maps, each one sheet.

\section{SUMMARY}

The Umpqua, North Umpqua, and Clearwater Rivers are valuable power streams with large fall and well-sustained flow, and the Umpqua and North Umpqua have possibilities for storage. Mill Creek, a tributary of the Umpqua River, has possibilities for storage and a concentrated fall, so that it also is valuable for power. The South Umpqua River and Steamboat Creek, a tributary of the North Umpqua, have some potential power value, but it is questionable whether the sites on these streams can ever be economically utilized. Rock Creek and the Little River, both tributary to the North Umpqua River; Cow Creek, a tributary of the South Umpqua River; and Elk Creek, a tributary of the Umpqua River, have little value for power.

There is but one developed site in the Umpqua River Basin, a plant of 1,900 horsepower on the North Umpqua River at Winchester, near Roseburg. Proposed sites at Rock Creek, Boundary, Toketee Falls, and Lemolo Falls on the North Umpqua River and on the lower Clearwater River are being investigated by the California-Oregon Power Co. under a permit from the Federal Power Commission.

The scheme of utilization proposed in this report contemplates the storage of 30,000 acre-feet of water in Diamond Lake and the storage of 422,000 acrefeet of water in the Coles Valley Reservoir, on the Umpqua River below the junction of the North and South Umpqua. Some additional power could also be obtained by drawing down the head at dam sites on the Umpqua and North Umpqua Rivers.

Twenty-two power sites are proposed for the Umpqua and North Umpqua Rivers. (See pl. 15.) The total potential power at these sites without storage is 214,000 horsepower for 90 per cent of the time and 473,000 horsepower for 50 per cent of the time, With storage, the sum of the estimated potential 


\section{CONTRIBUTIONS TO HYDROLOGY OF UNITED STATES, 1929}

power at the individual sites is 302,000 horsepower for 90 per cent of the time and 446,000 horsepower for 50 per cent of the time. But if all plants were operated as one system a minimum output of about 350,000 horsepower could be obtained in an ordinary year. In 1926, under the assumed conditions of operation, a minimum output of 283,000 horsepower could have been obtained. These estimates of potential power with storage assume that the Perdue and Days Creek reservoirs on the South Umpqua River would also be built.

The reservoir sites on the North Umpqua River at Toketee Falls and Poole Creek, if found to be feasible, might add as much as 100,000 horsepower to the potential power of the basin for 90 per cent of the time. Power from water stored at these sites has not been included in the estimates in this report.

Fifteen power sites are proposed on the South Umpqua River and Fish Lake Creek, including the two proposed reservoirs at Perdue and Days Creek. The total potential power at these sites without storage amounts to 8,300 horsepower for 90 per cent of the time and 61,000 horsepower for 50 per cent of the time. With storage in the Fish Lake, Perdue, and Days Creek reservoirs, the potential power is 20,000 horsepower for 90 per cent of the time and 62,000 horsepower for 50 per cent of the time.

Eleven power sites are proposed on tributaries of the Umpqua and North. Umpqua Rivers. The potential power without storage at these sites amounts to 21,000 horsepower for 90 per cent of the time and 39,000 horsepower for 50 per cent of the time. With storage, the potential power is 32,000 horsepower for 90 per cent of the time and 41,000 horsepower for 50 per cent of the time.

The total potential power of the Umpqua River Basin without storage is $\mathbf{2 4 3 , 0 0 0}$ horsepower for 90 per cent of the time and 573,000 horsepower for 50 per cent of the time. With storage the total potential power can be increased to 354,000 horsepower for 90 per cent of the time and 549,000 horsepower for 50 per cent of the time. With unified operation the power available 90 per cent of the time could be increased in an average year to more than 400,000 horsepower, of which 350,000 horsepower would be on the Umpqua and North Umpqua Rivers, 15,000 horsepower on the Clearwater River, and 9,000 horsepower on Mill Creek.

Table 1 summarizes the data for the developed site at Winchester and the undeveloped power sites in the Umpqua River Basin. 
TABLE 1.-Power sites in Umpqua River Basin

[Estimates of power based on static head and over-all efficiency of 70 per cent]

Developed power site

\begin{tabular}{|c|c|c|c|c|c|c|c|c|c|c|c|c|}
\hline \multirow{3}{*}{ [ Index No. } & \multirow{3}{*}{ Name } & \multirow{3}{*}{ Stream } & \multicolumn{5}{|c|}{ With existing flow } & \multicolumn{5}{|c|}{ With regulated flow a } \\
\hline & & & \multirow{2}{*}{$\begin{array}{l}\text { Gross } \\
\text { head } \\
(\mathrm{H}) \\
\text { (feet) }\end{array}$} & \multicolumn{2}{|c|}{$\begin{array}{l}\text { Flow (second- } \\
\text { feet) }\end{array}$} & \multicolumn{2}{|c|}{ Horsepower } & \multirow{2}{*}{$\begin{array}{c}\text { Installed } \\
\text { horsepower }\end{array}$} & \multicolumn{2}{|c|}{$\begin{array}{c}\text { Flow (second- } \\
\text { feet) }\end{array}$} & \multicolumn{2}{|c|}{ Horsepower. } \\
\hline & & & & $\begin{array}{l}90 \text { per } \\
\text { cent of } \\
\text { time } \\
\text { (Q90) }\end{array}$ & $\begin{array}{l}50 \text { per } \\
\text { cent of } \\
\text { time } \\
\text { (Q50) }\end{array}$ & 0.08HQ90 & $0.08 \mathrm{HQ} 50$ & & $\begin{array}{c}90 \text { per } \\
\text { cent of } \\
\text { time }\end{array}$ & $\begin{array}{l}50 \text { per } \\
\text { cent of } \\
\text { time }\end{array}$ & $0.08 \mathrm{HQ90}$ & $0.08 \mathrm{HQ} 50$ \\
\hline 12 RB $17 \ldots$ & Winchester..... & North Umpqua River..... & 12 & 960 & 2,420 & 922 & 2,320 & 1,900 & 1,520 & 2,570 & 1,460 & 2,470 \\
\hline
\end{tabular}

Undeveloped power sites on North Umpqua and Umpqua Rivers

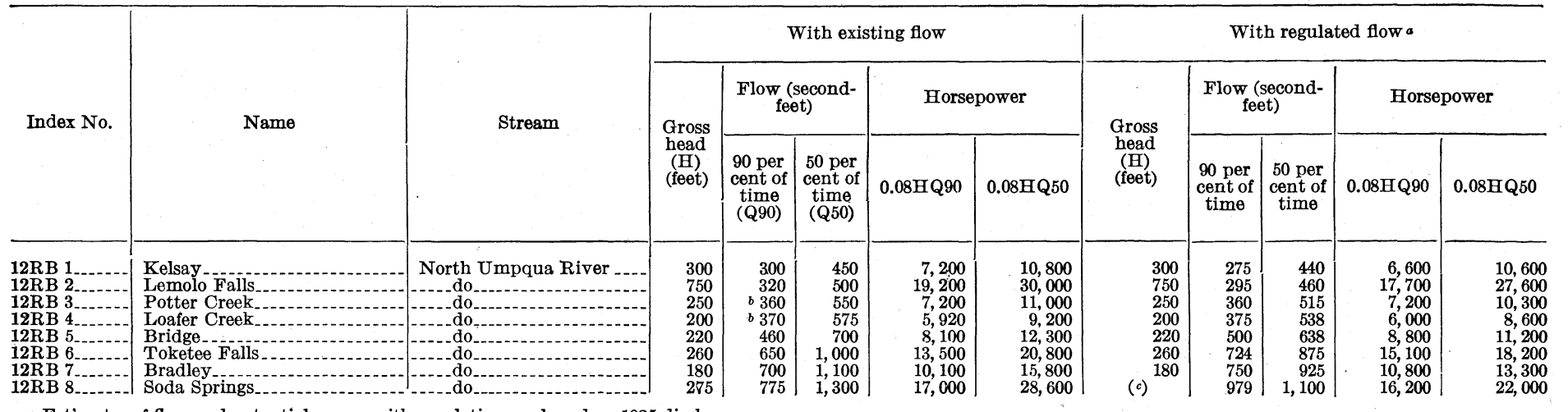

a Estimates of flow and potential power with regulation are based on 1925 discharge.

b Estimated from measurements above Lake Creek below Lemolo Falls and at Toketee Falls. 
TABLE 1.-Power sites in Umpqua River Basin-Continued

Undeveloped power sites on North Umpqua and Umpqua Rivers-Continued

\begin{tabular}{|c|c|c|c|c|c|c|c|c|c|c|c|c|}
\hline \multirow{3}{*}{ Index No. } & \multirow{3}{*}{ Name } & \multirow{3}{*}{ Stream } & \multicolumn{5}{|c|}{ With existing flow } & \multicolumn{5}{|c|}{ With regulated flow } \\
\hline & & & \multirow{2}{*}{$\begin{array}{c}\text { Gross } \\
\text { head } \\
(\mathrm{H}) \\
\text { (feet) }\end{array}$} & \multicolumn{2}{|c|}{$\begin{array}{c}\text { Flow (second- } \\
\text { feet) }\end{array}$} & \multicolumn{2}{|c|}{ Horsepower } & \multirow{2}{*}{$\begin{array}{c}\text { Gross } \\
\text { head } \\
(\mathrm{H}) \\
\text { (feet) }\end{array}$} & \multicolumn{2}{|c|}{$\begin{array}{c}\text { Flow (second- } \\
\text { feet) }\end{array}$} & \multicolumn{2}{|c|}{ Horsepower } \\
\hline & & & & $\begin{array}{c}90 \text { per } \\
\text { cent of } \\
\text { time } \\
(\mathrm{Q} 90)\end{array}$ & $\begin{array}{c}50 \text { per } \\
\text { cent of } \\
\text { time } \\
(\mathrm{Q} 50)\end{array}$ & 0.08HQ90 & $0.08 \mathrm{HQ} 50$ & & $\begin{array}{c}90 \text { per } \\
\text { cent of } \\
\text { time. }\end{array}$ & $\begin{array}{c}50 \text { per } \\
\text { cent of } \\
\text { time }\end{array}$ & $0.08 \mathrm{HQ90}$ & $0.08 \mathrm{HQ50}$ \\
\hline 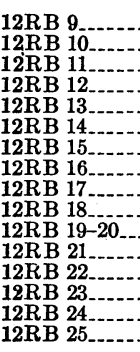 & $\begin{array}{l}\text { Copeland } \\
\text { Steamboat } \\
\text { Boundary } \\
\text { Clark Ranch } \\
\text { Rock Creek } \\
\text { Glide } \\
\text { Horseshoe Bend } \\
\text { Oak Creek } \\
\text { Winchester } \\
\text { Pacific Highway } \\
\text { Wolf Creek or Coles Valley } \\
\text { Kellogg } \\
\text { Smith Ferry } \\
\text { Kelley's Smith Ferry } \\
\text { Sawyer Rapids } \\
\text { Scottsburg }\end{array}$ & 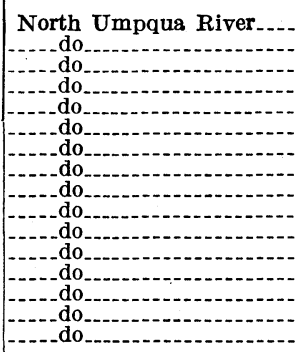 & $\begin{array}{r}290 \\
190 \\
225 \\
110 \\
120 \\
60 \\
90 \\
70 \\
80 \\
20 \\
145 \\
70 \\
94 \\
85 \\
59 \\
100\end{array}$ & $\begin{array}{r}825 \\
850 \\
890 \\
900 \\
900 \\
950 \\
950 \\
955 \\
960 \\
960 \\
1,150 \\
1,150 \\
1,150 \\
1,150 \\
1,160 \\
1,160\end{array}$ & $\begin{array}{l}1,400 \\
1,500 \\
1,800 \\
1,950 \\
2,000 \\
2,400 \\
2,400 \\
2,410 \\
2,420 \\
2,420 \\
4,620 \\
4,620 \\
4,620 \\
4,620 \\
4,750 \\
4,800\end{array}$ & $\begin{array}{r}19,100 \\
12,900 \\
16,000 \\
7,900 \\
8,640 \\
4,560 \\
6,830 \\
5,350 \\
6,140 \\
1,540 \\
13,400 \\
6,440 \\
8,640 \\
7,820 \\
5,480 \\
9,270\end{array}$ & $\begin{array}{r}32,400 \\
22,800 \\
32,400 \\
17,200 \\
19,200 \\
11,500 \\
17,300 \\
13,500 \\
15,500 \\
3,870 \\
53,600 \\
25,900 \\
34,700 \\
31,400 \\
22,400 \\
38,400\end{array}$ & 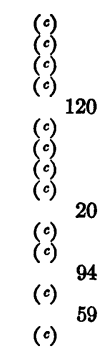 & $\begin{array}{l}1,020 \\
1,050 \\
1,450 \\
1,460 \\
1,460 \\
1,520 \\
1,520 \\
1,530 \\
1,520 \\
1,520 \\
3,500 \\
3,500 \\
3,500 \\
3,500 \\
3,500 \\
3,530\end{array}$ & $\begin{array}{l}1,280 \\
1,320 \\
1,950 \\
1,980 \\
1,980 \\
2,300 \\
2,400 \\
2,470 \\
2,570 \\
2,570 \\
5,150 \\
4,910 \\
4,910 \\
5,950 \\
5,950 \\
6,360\end{array}$ & $\begin{array}{r}18,900 \\
11,900 \\
18,200 \\
11,000 \\
14,000 \\
7,200 \\
10,900 \\
8,570 \\
9,700 \\
2,420 \\
33,500 \\
19,600 \\
26,300 \\
23,800 \\
16,500 \\
23,700\end{array}$ & $\begin{array}{r}32,400 \\
20,100 \\
32,400 \\
17,200 \\
19,000 \\
10,700 \\
16,200 \\
12,800 \\
14,900 \\
4,120 \\
45,000 \\
25,800 \\
36,900 \\
30,900 \\
28,100 \\
43,000\end{array}$ \\
\hline . & $\begin{array}{l}\text { Total (excluding sites } 22 \\
\text { and 24). }\end{array}$ & |-_- & 4,090 & ........ & -........ & 214,110 & 473,470 & & $\ldots$ & .......... & 301,790 & 446,320 \\
\hline
\end{tabular}


Undeveloped power sites on tributaries of North Umpqua and Umpqua Rivers

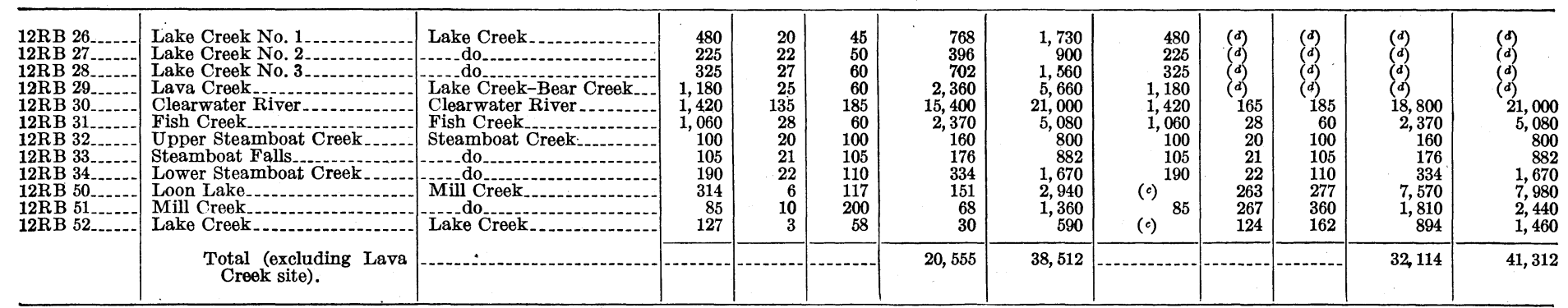

Undeveloped power sites on South Umpqua River

\begin{tabular}{|c|c|c|c|c|c|c|c|c|c|c|c|c|}
\hline 12RB 35 & Fish Lake & Fish Lake Creek. & 1,264 & 1.5 & 10 & 152 & 1,010 & 1,264 & 15 & 15 & 1,520 & 1,520 \\
\hline $12 \mathrm{RB} 36$ & Black Rock & South Umpqua River...-. & 67 & $10^{\circ}$ & 51 & 54 & 273 & 67 & 23 & 56 & 123 & $\begin{aligned} 1,020 \\
300\end{aligned}$ \\
\hline $12 \mathrm{RB} 37$ & South Umpqua Falls & do & 347 & 20 & 104 & 556 & 2,890 & 347 & 33 & 109 & 917 & 3,020 \\
\hline $12 \mathrm{RB} 38 \ldots$ & Boulder Creek & do & 195 & 25 & 146 & 390 & 2,280 & 195 & 35 & 150 & 546 & 2,320 \\
\hline $12 \mathrm{RB} 39$ & Dumont & do & 65 & 38 & 250 & 198 & 1,300 & 65 & 48 & 250 & 250 & 1,300 \\
\hline $12 \mathrm{RB} 40$ & Deadman Creek & - & 175 & 45 & 300 & 630 & 4,200 & 175 & 55 & 300 & 770 & 4,200 \\
\hline $12 \mathrm{RB} 41$ & Tiller & do & 160 & 75 & 600 & 960 & 7,680 & 160 & 85 & 600 & 1,090 & 7,680 \\
\hline $12 \mathrm{RB} 42$ & Coffee Creek & . do & 80 & 80 & 650 & 512 & 4,160 & 80 & 90 & 650 & 576 & 4,160 \\
\hline 12RB $43 \ldots$ & Perdue .......... & ..._do & 100 & 85 & 700 & 680 & 5,600 & & 250 & 700 & .800 & 5,600 \\
\hline $12 \mathrm{RB} 44$ & Days Creek & - do & 100 & 90 & 750 & 720 & 6,000 & (c) & 425 & 750 & - 1,360 & 6,000 \\
\hline 12RB 45 & Riddle.......... & do & 125 & 100 & 775 & 1,000 & 7,750 & 125 & 430 & 775 & 4,300 & 7,750 \\
\hline 12R B 46 & Myrtle Creek & do & 70 & 125 & 925 & 700 & 5,180 & 70 & 435 & 925 & 2,430 & 5,180 \\
\hline 12RB 47.. & Ruckles_-.-.... & . & 50 & 130 & 940 & 520 & 3,760 & 50 & 440 & 940 & 1,760 & 3,760 \\
\hline \multirow{3}{*}{$12 \mathrm{RB} 49$} & Dillard & do & 60 & 141 & 1,000 & 677 & 4,800 & 60 & 450 & 1.000 & 2,160 & 4.800 \\
\hline & Roseburg & do & 50 & 141 & 1,000 & 564 & 4,000 & 50 & 450 & 1,000 & 1,700 & 4,000 \\
\hline & Total_. & & & & & 8,313 & 60,883 & & & & 20,296 & 61,590 \\
\hline
\end{tabular}

- Variable.

Total flow at Diamond Lake stored during 7 months. Result would be increased power during low months July to November.

- Estimated. 


\section{INTRODUCTION}

The Umpqua River, one of the coast streams of southwestern Oregon, flows from the Cascade Range to the Pacific Ocean. Roseburg, the principal city in the basin, is 199 miles by highway south of Portland, the nearest large market for power. Power can also be transmitted to northern California, the State boundary being, roughly, 100 miles to the south. The Umpqua River Basin lies between the Rogue River on the south and the Willamette and Siuslaw Rivers on the north. The upper part of the basin is mountainous and covered with timber. In the middle part, around Roseburg considerable agricultural land is found, and then as the river approaches the coast it again flows through a rough, hilly country. Plate 15 shows the relative location of the basin and is an index to the location of the power sites.

\section{GEOGRAPHY}

The Umpqua River is formed by the junction of the North and South Umpqua, 6 miles northwest of Roseburg. The North Umpqua, with a drainage area of 1,300 square miles, supplies over 90 per cent of the low-water flow. It rises in Maidu Lake, near the summit of the Cascade Range, but it is no more than a small creek until it reaches the mouth of the Spring River, where a giant spring pours out a continuous flow of nearly 200 second-feet. The Clearwater River supplies another 200 second-feet during the dry summer, and these two sources account for two-thirds of the low water flow at the mouth of the Clearwater. The basin of the North Umpqua River is mostly covered with timber, and the upper portion is all in the Umpqua National Forest. The South Umpqua River has a drainage area of 1,990 square miles, but owing to the geologic character of the basin there is little ground storage, and during the months of low precipitation the stream flow is so low that the power that can be made continuously available without storage is only a small fraction of that which can be obtained on the North Umpqua. The cost of storage on the South Umpqua would be high, so it will probably be many years before any considerable amount of power is developed on that stream.

The principal tributaries of the North Umpqua River are Lake Creek, at the head of which is Diamond Lake; the Clearwater River; Fish, Steamboat, Rock, and Cow Creeks; and the Little River. Lake Creek has a fall of 1,082 feet in 13 miles, but the discharge is low during the summer. The Clearwater River is fed by springs and has a large, continuous flow and the fall is 1,500 feet in 10 miles, 
making it the most valuable power stream among the tributaries. Fish Creek, Steamboat Creek, Rock Creek, and th. Little River have periods of low flow that prevent any large possibilities of developing power without very expensive storage.

The tributaries of the South Umpqua River have characteristics similar to the main stream, the long period of low flow precluding any considerable use for power.

There are some small lakes at the head of the South Umpqua River, but they are not large enough to be of any great value as reservoir sites.

The principal tributaries of the main Umpqua River are Mill Creek and Elk Creek. For several months in summer the discharge of Elk Creek is low and its power value is small.

Mill Creek, the outlet of Loon Lake, is a stream about $81 / 2$ miles in length, tributary to the Umpqua River at a point about 20 miles above its mouth. Loon Lake, which covers an area of 269 acres at low-water line, is fed by Lake Creek, a stream roughly 25 miles in length, which has its source in the Coast Range. Loon Lake lies at the lower end of a natural reservoir, the flooding of which would inundate a considerable area of valuable agricultural lands. Lake Creek, which is really the head of Mill Creek, follows a narrow mountain valley that widens into a natural basin around Loon Lake. The course of the combined streams throughout is on bedrock, except for a short distance above Loon Lake. Loon Lake is said by geologists to be the result of a great mountain slide that dammed the stream course. Above this lake the stream has little fall, but below the lake, where it continues as Mill Creek, it drops 300 feet in a distance of about 3 miles. Below this swift stretch the stream is rather sluggish, dropping only 100 feet in the remaining $51 / 2$ miles of its course. The entire basin is heavily timbered except for a few acres of marsh in the upper reservoir and except for the small area adjacent to Loon Lake, which is open and under intensive agricultural development. The ordinary mean annual run-off above Loon Lake could be stored in a reservoir that could be created at the lake, rendering this a valuable power stream. Diamond Lake, at the head of Lake Creek is an ideal reservoir site, but the water supply is deficient.

'At Coles Valley, below Roseburg, the topography is favorable for a large reservoir, and the water supply is sufficient, but much valuable land would be overflowed. Probably when a market for power is available the Coles Valley Reservoir will be financially feasible. 


\section{GEOLOGY ${ }^{1}$}

A description of the geology of numerous reservoir and dam sites examined during the investigation of sites in the Umpqua River Basin involves mention of so many structural features, formations, and types of rocks that a brief summary of the important events in the geologic history of western Oregon and a description of the areal distribution of the chief formations are given.

The known facts of the geologic history of western Oregon before Cretaceous time are meager, for the sediments then laid down have since been completely metamorphosed and now occur as schist, slate, and serpentine. These rocks are exposed along the lower part of the Rogue River in Jackson, Josephine, and Curry Counties. Dam sites in these rocks involve no problem of leakage, and all of them are satisfactory for foundations.

The Cretaceous period was ushered in with great intrusions of granodiorite and other igneous rocks and extensive movements of the crust. During Cretaceous time the northern and central parts of western Oregon lay below sea level, and on this area were deposited sediments that upon consolidation became conglomerate, shale, and sandstone. These sediments were then subjected to considerable folding, which has altered their original character and tilted the beds at steep angles. Outcrops of these sediments are seen along the Illinois and Rogue Rivers in Josephine and Curry Counties. Many of the rugged canyons and consequently the sites of large dams and reservoirs are located in the intrusive rocks of this period. In general these intrusive rocks form excellent sites from the point of view of both the geologist and the engineer, and they are as a whole better than the sites in any of the later formations. The granodiorite, diabase, and other intrusive rocks of this period cooled under the weight of overlying sediments and consequently do not have the porous texture and leaky contacts and joints that characterize so many of the later extrusive rocks. Moreover, in crushing strength the intrusive rocks are usually equal to granite and are all sufficiently strong to support large structures.

The chief event during the Tertiary period was the building of the Cascade Range by uplift and volcanic action. The Eocene, or early part of the Tertiary, was a time of deposition and marine invasion, during which extensive beds of sandstone and conglomerate were deposited. Many of the dam sites on the lower Umpqua River are in the sandstone beds of this epoch. Thick dikes and sills of ba-

1 This summary of the geology is based largely upon the numerous publications of $\mathrm{J}$. S. Diller, which appear as bulletins and geologic folios of the United States Geological Survey. 
saltic lava were intruded into the sediments, and in the outcrops of these intrusive rocks are found many of the finest sites on the Rogue River. 'The sites in the sedimentary rocks of this epoch are generally good, although there may be slight leakage along bedding planes.

During the later half of the Tertiary period, marine deposition continued over the northwestern part of the State, interrupted by occasional periods of uplift. None of the sites described in this report are located in the sedimentary rocks of this time. However, this epoch together with the Pleistocene was one of the most noteworthy periods of volcanic activity. Numerous volcanoes along the Cascade Mountains poured forth thick flows of lava and emitted showers of pumice. Many of these lava flows coursed down river valleys and partly filled them. Since that time the rivers have excavated portions of these lava fills and formed narrow canyons with vertical walls of lava. Most of this rock is fractured and fissured and commonly covers ancient gravel beds through which impounded water might escape rapidly. In places this combination gives excellent dam sites, so far as purely physical form is considered, but such places are treacherous for storing water because of leakage. The pumice deposits of this epoch cover wide areas, especially in the vicinity of Crater Lake, and they form a thick pumice flow in the Rogue River Valley. The misplaced drainage and concealed river channels caused by this epoch of volcanism make reservoir sites in these volcanic deposits hazardous.

In the Pleistocene epoch the high peaks of the Cascades were covered with glaciers, which moved down the valleys of most of the larger streams. During the existence of these glaciers the master streams were overloaded with débris and aggraded their valleys. Later erosion excavated valleys in the glacial gravel, leaving the remnants of the fill as terraces. Some of the dam sites are in this material and are consequently poor, because of the amount of excavation necessary to reach bedrock. Diamond Lake, at the head of Lake Creek, is an ideal reservoir site, but the water supply is deficient.

\section{CLIMATE}

The climate of the lower and central Umpqua River Basin is mild, the temperature seldom dropping below freezing. Even at Diamond Lake, the highest point at which there would be any works, the winters are not severe, although there is considerable snow.

The amount of annual rainfall differs greatly in different parts of the basin. Along the coast it is about 80 inches, but in the Coast Range, a few miles inland, it is believed to reach 100 inches. Farther upstream, at Roseburg, it drops to 33 inches, and in the Cow Creek Basin, south of Roseburg, it is 27 inches or less. At the higher alti- 
tudes, on the North and South Umpqua, the rainfall gradually increases to 50 to 75 inches.

In this area, as in all of western Oregon, there is heavy precipitation during the winter and spring, but very little in the summer and early fall. The result is a period of low run-off on streams such as the South Umpqua, which has little ground storage. On the North Umpqua the flow is sustained through the dry summer months by the discharge of large springs, which show little decrease in flow even in very dry years.

Tables 2 and 3 summarize the records of temperature and precipitation at points in or adjacent to the Umpqua River Basin.

TABLE 2.-Mean monthly and yearly temperature $\left({ }^{\circ} F.\right)$ in or near the Umpqua River Basin

\begin{tabular}{|c|c|c|c|}
\hline Month & Port Orford $a$ & Roseburg & Prospect $b$ \\
\hline $\begin{array}{l}\text { January } \\
\text { February } \\
\text { March } \\
\text { April } \\
\text { May } \\
\text { June } \\
\text { July } \\
\text { August } \\
\text { September } \\
\text { October } \\
\text { November } \\
\text { December }\end{array}$ & $\begin{array}{l}45.8 \\
46.4 \\
47.4 \\
49.2 \\
51.4 \\
55.0 \\
58.3 \\
58.9 \\
57.5 \\
54.4 \\
49.4 \\
47.2\end{array}$ & $\begin{array}{l}41.2 \\
43.4 \\
47.1 \\
51.0 \\
56.0 \\
62.5 \\
67.4 \\
68.0 \\
62.9 \\
53.9 \\
45.9 \\
41.9\end{array}$ & $\begin{array}{l}35.0 \\
38.4 \\
42.2 \\
47.0 \\
52.4 \\
58.1 \\
65.9 \\
64.8 \\
57.8 \\
49.8 \\
41.9 \\
35.5\end{array}$ \\
\hline $\begin{array}{l}\text { Yearly mean. } \\
\text { Minimum temperature in } 1925 \\
\text { Altitude. }\end{array}$ & $\begin{array}{l}51.7 \\
32 \\
71\end{array}$ & $\begin{array}{l}53.5 \\
31 \\
510\end{array}$ & 2,800 \\
\hline
\end{tabular}

a Not in the Umpqua River Basin but indicates temperature along the seacoast.

$b$ In the Rogue River Basin and indicates the temperature in the mountains at head of the Umpqua River.

TABLE 3.-Mean monthly precipitation, in inches, in or near the Umpqua River Basin

\begin{tabular}{|c|c|c|c|c|c|c|}
\hline Month & Gardiner & Umpqua & Roseburg & Riddle & Musick & $\begin{array}{l}\text { Crater } \\
\text { Lake }^{a}\end{array}$ \\
\hline $\begin{array}{l}\text { January } \\
\text { February } \\
\text { March } \\
\text { April } \\
\text { May } \\
\text { June } \\
\text { July } \\
\text { August } \\
\text { September } \\
\text { October } \\
\text { November. } \\
\text { Decomber }\end{array}$ & $\begin{array}{r}12.22 \\
10.40 \\
9.96 \\
6.25 \\
4.84 \\
2.70 \\
.61 \\
.82 \\
2.76 \\
5.34 \\
11.28 \\
12.13\end{array}$ & $\begin{array}{r}\text { 6. } 53 \\
6.32 \\
6.24 \\
3.94 \\
2.68 \\
.98 \\
.26 \\
1.11 \\
4.42 \\
7.87 \\
8.97 \\
8.18\end{array}$ & $\begin{array}{r}\text { 5. } 43 \\
4.42 \\
\text { 3. } 45 \\
2.29 \\
1.91 \\
1.13 \\
.36 \\
.30 \\
1.22 \\
2.52 \\
4.63 \\
5.44\end{array}$ & $\begin{array}{r}5.19 \\
3.40 \\
2.55 \\
1.86 \\
1.30 \\
.79 \\
.48 \\
.34 \\
.91 \\
1.92 \\
4.41 \\
3.63\end{array}$ & $\begin{array}{r}15.00 \\
7.82 \\
7.80 \\
7.29 \\
6.25 \\
5.42 \\
1.06 \\
1.08 \\
5.72 \\
5.11 \\
12.55 \\
9.59\end{array}$ & $\begin{array}{r}6.69 \\
6.03 \\
4.99 \\
3.09 \\
1.89 \\
1.56 \\
.68 \\
1.08 \\
1.81 \\
4.66 \\
5.28 \\
13.53\end{array}$ \\
\hline Yearly mean. & $\begin{array}{r}79.31 \\
72\end{array}$ & $\begin{array}{r}60.50 \\
110\end{array}$ & $\begin{array}{r}33.10 \\
510\end{array}$ & $\begin{array}{r}26.78 \\
703\end{array}$ & $\begin{array}{l}84.69 \\
5,530\end{array}$ & $\begin{array}{l}51.29 \\
6,016\end{array}$ \\
\hline
\end{tabular}

a 1922-1924.

b 1922-1925.

FACTORS AFFECTING HYDRAULIC STRUCTURES

The small amount of ice that forms on the streams in the Umpqua River Basin would not cause much trouble in the operation of power 
plants. The upper sections of both the South Umpqua and North Umpqua Rivers are too steep to be used for logging, and any floating débris could easily be removed at the dams. The rivers carry practically no silt except during floods.

Irrigation does not affect the North Umpqua River, except for some small diversions on tributaries. The tributaries of the South Umpqua below Tiller are used for irrigation, but their flow is small. The summer discharge of Calapooya Creek is also used for irrigation. The total diversions for irrigation, however, are but a small percentage of the summer flow of the Umpqua and North Umpqua Rivers. On the South Umpqua River no exact figures are available, but the extreme low flow at Brockway might be doubled if there were no irrigation, although this is only a guess. Future requirements for diversion will not be great, because there is little land that can be irrigated economically from the North Umpqua and Umpqua Rivers, and the water supply is not very great on the South Umpqua.

Tidewater extends up the Umpqua River as far as Scottsburg, at the head of navigation. The first power site is just above Scottsburg, where the depth of the water at low stages is only about 1 foot. The operation of the power plants would have little effect on navigation below Scottsburg, and this effect would undoubtedly be favorable.

There is not much valuable agricultural land on the Umpqua River below Coles Valley, and the cost of relocating roads and paying for land flooded by proposed reservoirs would be only a small percentage of the total cost of the projects. Coles Valley and the valley of Calapooya Creek constitute a rich agricultural area, and the cost of storage at the Wolf Creek and Coles Valley sites will be high and may prevent the use of the sites. On both the North Umpqua and the South Umpqua the dams proposed would not cause excessive damage by flooding lands or buildings.

A number of summer homes and a hotel and resort on Diamond Lake have acquired certain rights to the use of the lake for recreation, but this use would not be precluded by the use of the lake as a reservoir site. Possibly it would be necessary to move some of the cottages back a short distance if the lake were raised 5 feet, but that would be the only expense, and it would be slight.

\section{VARIATION IN STREAM FLOW}

Records of stream flow have been obtained on the Umpqua River at Elkton since October, 1905. Records at other points cover much shorter periods, but the comparative run-off at Elkton for these periods gives some idea whether the flow recorded at each station was higher or lower than normal. Likewise the record at Elkton 
has been compared with the longer records on the Columbia River at The Dalles and the Willamette River at Albany and with the rainfall records. (See fig. 12.) The longest record is that for the

RUN-OFF IN INCHES

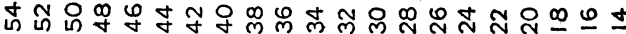

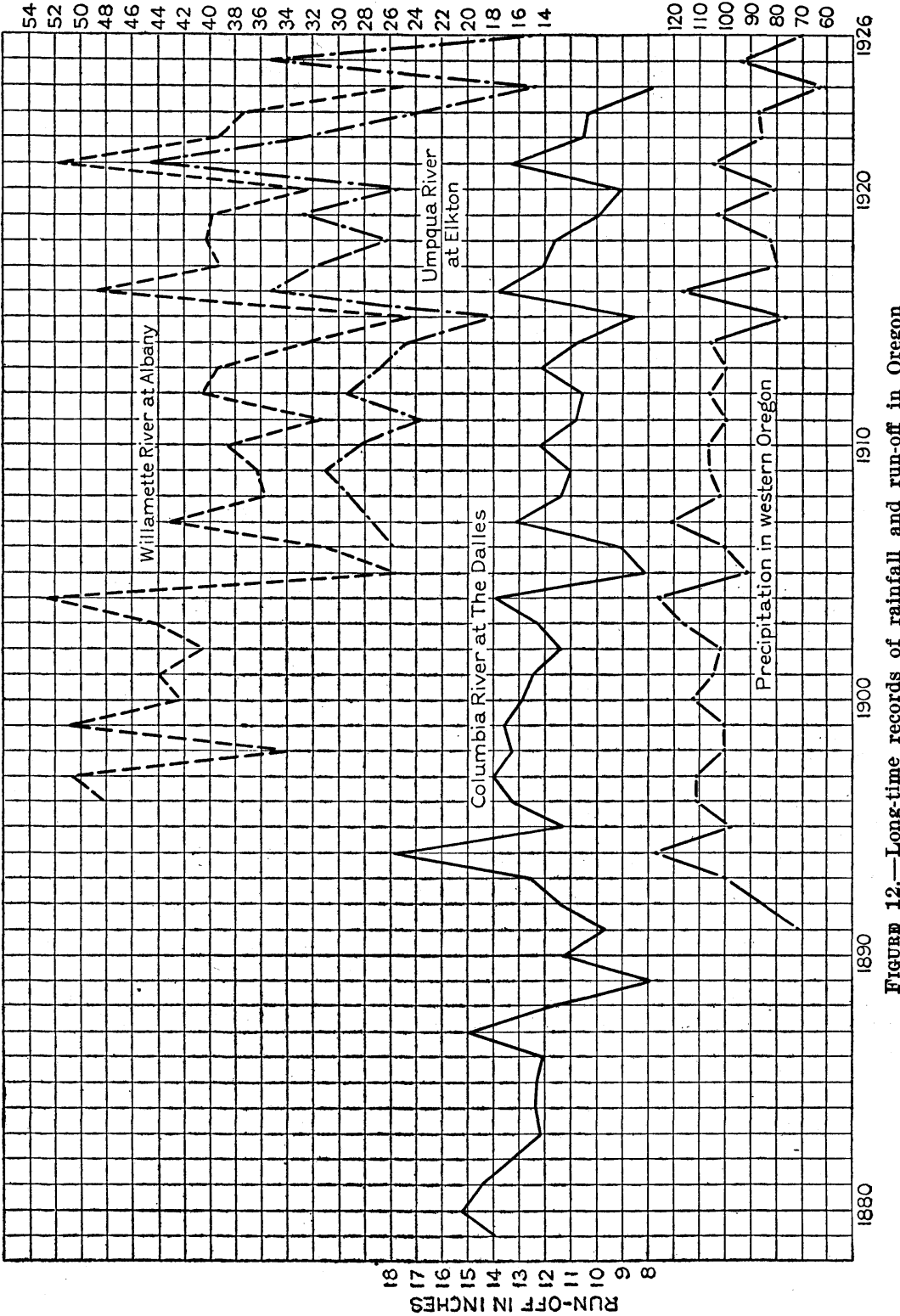

PER CENT OF MEAN

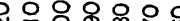

政

Columbia River at The Dalles, which began in 1879. This record shows three dry periods prior to 1924. The first was in 1889. For that year few data except the record of the flow of the Columbia 
River at The Dalles are available on which to base an estimate of the dryness. But Weather Bureau reports for 1889 state that the year was very dry in eastern Oregon and in the lower Willamette Valley, so it is inferred that this was not an extremely dry year in southwestern Oregon, where the Umpqua River is situated, and the records of rainfall bear out this inference. In 1891 the precipitation in western Oregon was 71 per cent of the mean, and in 1924 it was 61 per cent of the mean. These rather meager facts seem to indicate that the flow of the Umpqua River was lower in 1924 than in either 1889 or 1891. The third dry period came in 1905, and for this more information is available. The precipitation was 91 per cent of the mean. The run-off of the Willamette River at Albany was nearly 2 inches greater than in 1924. The Link River at Klamath Falls had a mean annual discharge of 2,140 second-feet in 1905, as compared with 2,230 second-feet in 1906 , which was probably about the normal, as in 1906 the mean annual discharge at Elkton was nearly normal. In 1924 so much water was diverted from the Link River above this point that no comparison is possible for that year. It seems probable however, that the run-off of the Umpqua River at Elkton was greater in 1905 than in 1924. Beginning with 1906, records are available for the Umpqua River at Elkton.

Records on the Columbia River since 1879 and the records of precipitation for western Oregon beginning with 1891 show that a very dry year comes on the average once in eight years. In the period of years beginning with 1879 the dry years were 1889, 1891, $1905,1915,1924$, and 1926. The dryest year was probably 1924 . The record of precipitation for western Oregon also shows a continued dry period from 1915 to 1926 and an extremely dry period from 1922 to 1926 . (See fig. 12.)

The records available for the Umpqua River cover the dry period from 1915 to 1926, and the estimates of power available are based on the record for this period. The estimates are therefore conservative and probably are somewhat low. From the records available it can be assumed that a year approaching 1924 in dryness will occur once in 8 or 10 years, and that a drier year may occur only once in a long period, possibly as long as 100 years, but that it probably will not greatly exceed 1924 in dryness.

The records obtained on the Umpqua River near Elkton are summarized in Tables 4 and 5. The Q90 flow is shown to be remarkably consistent, ranging from 1,020 to 1,240 second-feet, except in 1924, when it fell to 790 second-feet, and in 1926, when it was 735 second-feet. The Q50 flow ranged from 3,120 to 10,700 second-feet, except in 1924, when it fell to 2,040 second-feet, and in 1926, when it 
was 1,590 second-feet. The greatest recorded discharge of the Umpqua River at Elkton was 172,000 second-feet, but the mean flow for the day on which that stage occurred was 157,000 second-feet. The minimum recorded daily discharge at Elkton was 670 second-feet in 1926. Prior to 1924, when it was 680 second-feet, the minimum recorded mean daily discharge was 930 second-feet.

The mean annual discharge of the South Umpqua River at Brockway is roughly 1.4 second-feet to the square mile, whereas the mean annual discharge of the North Umpqua at Winchester is roughly 2.9 second-feet to the square mile. The flow of the South Umpqua also is more variable, the Q90 flow being 141 second-feet for the periods 1907-1911 and 1924-1925 and the Q50 flow being 1,000 second-feet, or seven times as great. On the North Umpqua River at Winchester for the period 1909-1913 the Q90 flow was about 1,000 second-feet and the Q50 flow 2,850 second-feet, or 2.85 times the Q90 flow. The sustained discharge and the fact that the low-water flow enters the river mostly above an altitude of 2,400 feet explain the great potential power of the North Umpqua River.

Figure 13 shows duration curves for several gaging stations in the Umpqua River Basin.

TABLE 4.-General summary of stream-flow data of Umpqua River near Etkton, Oreg., 1906-1926

\begin{tabular}{|c|c|c|c|c|c|c|c|}
\hline \multirow{2}{*}{ Year } & \multicolumn{5}{|c|}{ Discharge in second-feet } & \multirow{2}{*}{$\begin{array}{l}\text { Index of } \\
\text { run-off } a\end{array}$} & \multirow{2}{*}{$\begin{array}{l}\text { Index of } \\
\text { precipi- } \\
\text { tation } a\end{array}$} \\
\hline & Q90 & Q50 & Minimum & Maximum & Mean & & \\
\hline $\begin{array}{l}1905-6 \\
1906-7 \\
1907-8 \\
1908-9 \\
1909-10 \\
1910-11 \\
1911-12 \\
1912-13 \\
1913-14 \\
1914-15 \\
1915-16 \\
1916-17 \\
1917-18 \\
1918-19 \\
1919-20 \\
1920-21 \\
1921-22 \\
1922-23 \\
1923-24 \\
1924-25 \\
1925-26\end{array}$ & 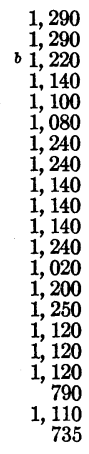 & $\begin{array}{r}4,960 \\
\text { b } 4,950 \\
6,060 \\
4,900 \\
4,310 \\
4,710 \\
5,380 \\
5,780 \\
3,950 \\
3,600 \\
6,600 \\
7,910 \\
3,120 \\
4,060 \\
3,620 \\
10,700 \\
7,480 \\
4,710 \\
2,040 \\
5,420 \\
1,590\end{array}$ & $\begin{array}{r}1,150 \\
1,290 \\
1,290 \\
990 \\
960 \\
960 \\
1,060 \\
1,150 \\
1,040 \\
950 \\
950 \\
1,140 \\
930 \\
960 \\
1,160 \\
1,120 \\
1,040 \\
1,040 \\
680 \\
830 \\
670\end{array}$ & \begin{tabular}{r}
61,400 \\
\hdashline 84,600 \\
93,000 \\
138,000 \\
66,200 \\
86,800 \\
46,300 \\
57,100 \\
29,100 \\
111,000 \\
38,700 \\
58,000 \\
76,000 \\
45,100 \\
69,200 \\
64,800 \\
93,500 \\
37,100 \\
96,500 \\
60,200
\end{tabular} & $\begin{array}{r}b 7,860 \\
\text { s, 390 } \\
7,680 \\
6,320 \\
7,960 \\
7,200 \\
6,690 \\
4,790 \\
9,520 \\
8,550 \\
7,050 \\
8,870 \\
6,780 \\
12,100 \\
8,910 \\
6,440 \\
3,950 \\
9,600 \\
4,040\end{array}$ & $\begin{array}{r}b 1.04 \\
1.11 \\
1.02 \\
.84 \\
1.06 \\
.96 \\
.89 \\
.64 \\
1.26 \\
1.14 \\
.94 \\
1.18 \\
.90 \\
1.61 \\
1.18 \\
.86 \\
.52 \\
1.27 \\
.54\end{array}$ & $\begin{array}{l}1.00 \\
1.21 \\
1.02 \\
1.05 \\
1.06 \\
1.00 \\
1.05 \\
1.00 \\
1.05 \\
.76 \\
1.16 \\
.78 \\
.82 \\
.93 \\
.79 \\
1.05 \\
.86 \\
.87 \\
.61 \\
.94 \\
.70\end{array}$ \\
\hline $\begin{array}{l}\text { Maximum } \\
\text { Miiimum } \\
\text { Median }\end{array}$ & $\begin{array}{r}1,290 \\
735 \\
1,140\end{array}$ & $\begin{array}{r}10,700 \\
1,590 \\
4,900\end{array}$ & $\begin{array}{r}1,290 \\
670 \\
1,040\end{array}$ & $\begin{array}{r}138,000 \\
29,100 \\
36,200\end{array}$ & $\begin{array}{r}12,100 \\
3,950 \\
7,680\end{array}$ & $\begin{array}{r}1.61 \\
.52 \\
.98\end{array}$ & $\begin{array}{l}1.21 \\
.61 \\
1.00\end{array}$ \\
\hline
\end{tabular}

a Obtained by taking the mean for the 21-year period as 1 .

$\checkmark$ Estimated. 
TABLE 5.-Summary of monthly mean discharge, in second-feet, of Umpqua River near Elkton, Oreg., 1906-1926

\begin{tabular}{|c|c|c|c|c|c|c|c|c|c|c|c|c|c|}
\hline Year & Oct. & Nov. & Dec. & Jan. & Feb. & Mar. & Apr. & May & June & July & Aug. & Sept. & Year \\
\hline & $\begin{array}{r}a 1,630 \\
1,460\end{array}$ & $\begin{array}{l}1,580 \\
6,270\end{array}$ & $\begin{array}{r}5,800 \\
10,400\end{array}$ & & 16,000 & 10,200 & 8,310 & $\begin{array}{r}9,080 \\
a \quad 6,000\end{array}$ & $\begin{array}{l}8,420 \\
3,400\end{array}$ & $\begin{array}{l}2,040 \\
1,690\end{array}$ & $\begin{array}{l}1,360 \\
1,370\end{array}$ & $\begin{array}{l}1,470 \\
1,390\end{array}$ & 6,940 \\
\hline & i, 350 & 4,190 & 21,500 & & 12,200 & 12,600 & 7,970 & 7,170 & $\begin{array}{l}3,400 \\
4,990\end{array}$ & 2,100 & 1,400 & & 7,860 \\
\hline & a 4,880 & 6,500 & & & & 10,800 & 6,830 & 5,150 & 3,630 & 1,760 & 1,210 & 1,170 & 8,390 \\
\hline & 1,540 & 19,300 & & & & & 5,470 & 3,730 & 1,690 & 1,290 & 1,130 & 1,100 & 7,68 \\
\hline & & 9,410 & 12, & & & 7,930 & 6,960 & 6,430 & 2,830 & 1,490 & 1,050 & 1,340 & 6,320 \\
\hline & & 7,720 & & & & 10,5 & 5,980 & 11,800 & $6,660]$ & 2,490 & 1,360 & 1,580 & 7,9 \\
\hline & & 7,660 & 9,830 & & & 9,5 & 12,800 & 6,110 & 5,590 & 4,970 & 1,490 & 1,300 & 7,2 \\
\hline & 2,200 & 5,520 & 6,080 & & & 10,7 & 8,060 & 4,530 & 3,4 & 1,560 & 1,120 & 1,440 & 6,6 \\
\hline & 180 & 2,670 & 5,0 & 10 & & 6, & & 6,420 & 3,470 & 1,410 & 1,120 & 998 & 4,790 \\
\hline & 980 & 8,750 & 15,5 & & & & 10,500 & 8,050 & 3,490 & 4,820 & 1,610 & 1,220 & 9,52 \\
\hline & 1,140 & 3,610 & 9,660 & 10, & & 16,8 & & 13,700 & 9,180 & 3,780 & 1,390 & 1,250 & 8,55 \\
\hline & & 1,770 & 12,2 & & & & & & 1,9 & 1,200 & 1,050 & 972 & 7,0 \\
\hline & 1,190 & 3,560 & 5,68 & 19, & 23,0 & 22, & & 8,790 & 3,1 & 1,370 & 1,230 & 1,400 & 8,870 \\
\hline & 1,510 & 9,060 & 17,80 & 8,3 & & 7,8 & & 6,810 & 2,640 & 1,500 & 1,260 & 3,480 & 6,780 \\
\hline & 58 & & & 20 & 22, & & & 15,800 & 6,230 & 1,680 & 1,150 & 1,360 & 12,100 \\
\hline 192 & & 11,6 & 15,3 & 12 , & 14, & 15,100 & 14,700 & 11,500 & 6,100 & $\overrightarrow{1}, 650$ & 1,210 & 1,100 & 8,9 \\
\hline & 1,330 & 1,900 & & & & & & 5,280 & 4,410 & 1,810 & 1,150 & 1,070 & 6,440 \\
\hline & 780 & 2,050 & 9,58 & & 10,700 & 4,730 & 5,580 & 2,270 & 1,160 & 898 & 793 & 795 & 3,950 \\
\hline 192 & 10 & 22,800 & 13,500 & $21,600 \mid$ & & 5,820 & $11,200 \mid$ & 5,570 & 3,940 & 1,500 & 1,190 & 1,220 & 9,600 \\
\hline & 1,130 & 1,700 & 5,130 & $|5,790|$ & 23,100 & 5,210 & 2,430 & 1,970 & 1,050 & 742 & & & 4,040 \\
\hline Maximum.. & & 22,800 & 25,600 & 31,400 & 26,800 & 22,800 & $19,900 \mid$ & 15,800 & 9,180 & 4,970 & 1,610 & 3,480 & 12,100 \\
\hline & & & & & & & & 1,970 & 1,0 & 742 & 756 & 795 & 3, \\
\hline & 010 & 7,340 & & & & & 9,680 & 7,200 & 4,160 & 1,990 & 1,210 & 1,330 & \\
\hline & & 6,270 & & & & 10,600 & $|8,180|$ & 6,420 & 3,490 & 1,650 & 1,210 & 1,240 & \\
\hline
\end{tabular}

a Estimated.

\section{ANNUAL YIELD AND MINIMUM FLOW}

The estimates of power available at different sites are based on the flow of the stream for 50 per cent and 90 per cent of the time. On the Umpqua River the records at Elkton have been used, and it has been assumed that there will be little change in the Q50 and Q90 flows between the junction of the North Umpqua with the South Umpqua and the lowest power site at Scottsburg. On the North Umpqua the records at Winchester and Oak Creek and below Glide have been used to estimate the water available at sites between Glide and the mouth of the North Umpqua. For power sites on the North Umpqua above Rock Creek the records at the station above Rock Creek and at Toketee Falls have been used and compared with the results of miscellaneous measurements for sites above Toketee Falls. On the principal tributaries of the North Umpqua River-Steamboat Creek, Fish Creek, and the Clearwater River-some short summer records in 1924 give an idea of extreme low-water flow. On the South Umpqua River the estimates of water available are based on the records at Brockway, one year's record above Tiller, and miscellaneous measurements made in 1924 .

The minimum daily discharge of the Umpqua River at Elkton occurred in 1926, when it was 670 second-feet. In 1924 it was 680 second-feet, and in 1905 to 1920 it was 950 second-feet. In the 21 years of record the lowest mean yearly discharges were 3,950 secondfeet in 1924; 4,040 second-feet in 1926, and 4,790 second-feet in 1915 . The gaging stations on the North Umpqua River at Winchester and 
Oak Creek and below Glide measure the discharge for nearly the same run-off area, being only a few miles apart, with no large tributaries entering the North Umpqua between them. The minimum daily discharges at Winchester were 616 second-feet in 1926 and 688 second-

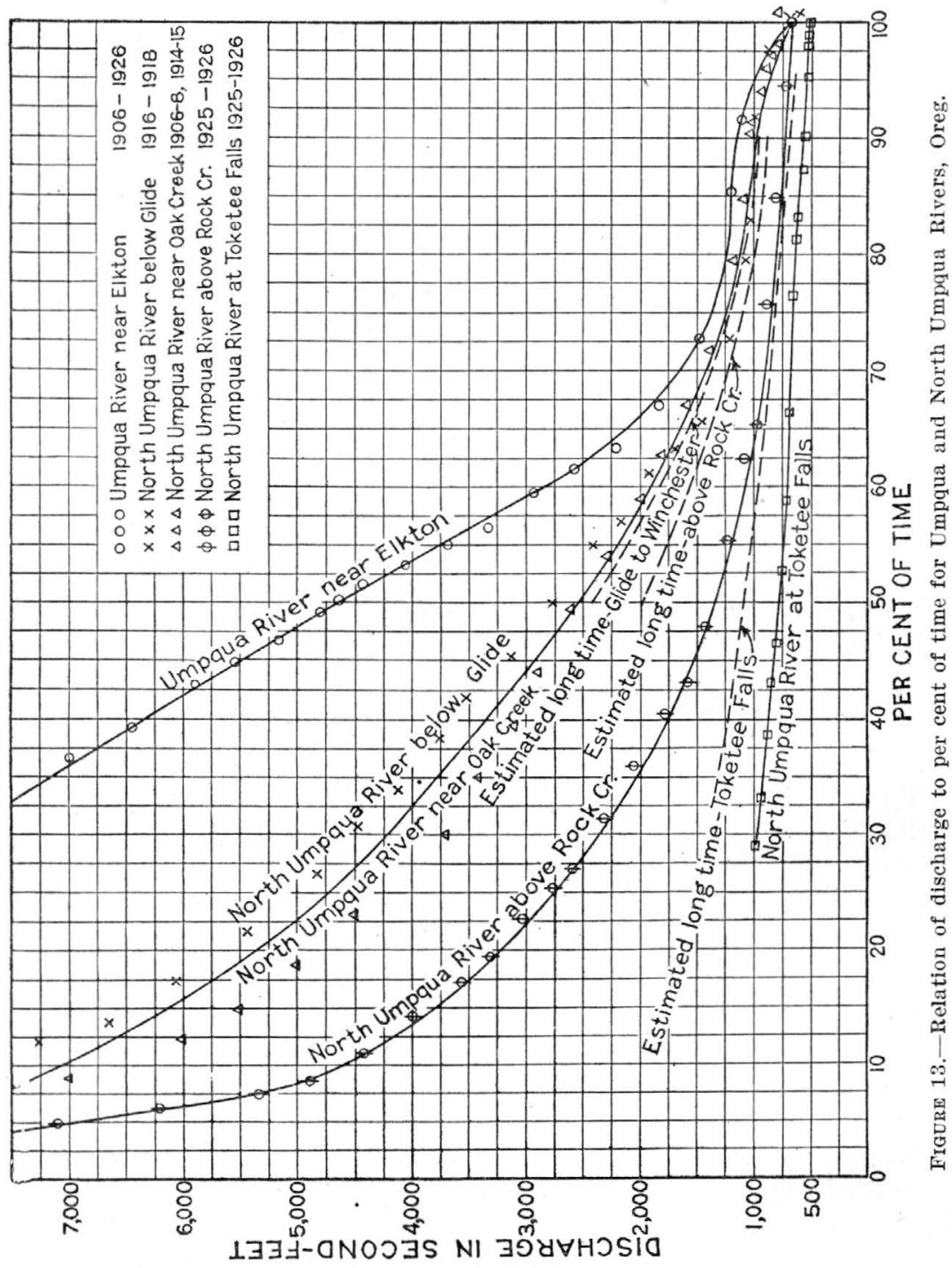

feet in 1924. The minimum recorded mean annual flow for the North Umpqua River was 2,000 second-feet at Winchester, in 1926. In 1924 the mean annual flow at Winchester was 2,160 second-feet. Only short records are available at Toketee Falls and above Rock Creek, but they include the low-water periods of 1924 and 1926. At the 
station above Rock Creek the minimum recorded daily discharge was 674 second-feet, in 1926, and the mean annual discharge at this station for the same year was 1,570 second-feet. At Toketee Falls the minimum recorded daily discharges were 516 second-feet in 1926 and 530 second-feet in 1924; the mean annual discharge in 1926 was 754 second-feet; in 1924 records are available for the summer only. On the South Umpqua River at Brockway the minimum recorded daily discharge was 36 second-feet, in 1926, and the minimum in 1924 was 49 second-feet; the minimum mean annual discharge was 1,050 second-feet, in 1924, and the mean in 1926 was 1,240 secondfeet. On Mill Creek below Loon Lake the minimum recorded discharge was 1.5 second-feet in 1910 and 1911. The potential power of this creek probably would not be utilized without storage, so the minimum flow is not so significant. The minimum recorded mean yearly discharge of Mill Creek was 266 second-feet in 1911; no records are available for 1924 and 1926. The minimum recorded flow of Lake Creek at the outlet of Diamond Lake was 12 secondfeet in 1924; in 1926 the minimum discharge was 16 second-feet. No records for a complete year are available at this station. An idea of the minimum flow of other streams can be obtained from the miscellaneous measurements listed in Table 8.

TABLE 6.-Gaging stations in Umpqua River Basin

\begin{tabular}{|c|c|c|}
\hline Stream & Location & Period of record \\
\hline $\begin{array}{l}\text { South Umpqua River } \\
\text { Do } \\
\text { Umpqua River } \\
\text { North Umpqua River } \\
\text {.Do } \\
\text { Do } \\
\text { Do Do } \\
\text { Do } \\
\text { Lake Creek } \\
\text { Clearwater River } \\
\text { Mill Creek }\end{array}$ & $\begin{array}{l}\text { At Tiller } \\
\text { Near Brockway. } \\
\text { Elkton } \\
\text { At Toketee Falls } \\
\text { Near Hoaglin, in sec. 18, T. } 26 \mathrm{~S} . \text {, } \\
\text { R. } 1 \text { W. } \\
\text { Above Rock Creek } \\
\text { Below Glide } \\
\text { Near Oak Creek, in sec. } 25, \mathrm{~T} .26 \\
\text { S., R. 5 W. } \\
\text { At Winchester } \\
\text { At Diamond Lake. } \\
\text { At Trap Creek } \\
\text { At outlet of Loon Lake,near Ash }\end{array}$ & $\begin{array}{l}\text { 1910-11. } \\
1905-1912 \text {, and 1924-1929. } \\
1905-1929 . \\
1914-1917,1924-1929 \text { (fragmentary). } \\
1911 \text { and } 1912 \text { (fragmentary). } \\
\text { 1924-1929. } \\
1915-1922 . \\
1905-1908,1913-1915 . \\
1908-1913,1924-1929 . \\
1922-1929 \text { (fragmentary) } \\
1928-29 . \\
1907-1912,1914-1917 .\end{array}$ \\
\hline
\end{tabular}

TABLE 7.-Records at temporary gaging stations in North Umpqua River Basin

Steamboat Creek above mouth of Canton Creek

\begin{tabular}{|c|c|c|c|c|c|c|c|c|}
\hline & Date & $\begin{array}{c}\text { Dis- } \\
\text { charge }\end{array}$ & Date & $\begin{array}{c}\text { Dis- } \\
\text { charge }\end{array}$ & Date & $\begin{array}{c}\text { Dis- } \\
\text { charge }\end{array}$ & Date & $\begin{array}{c}\text { Dis- } \\
\text { charge }\end{array}$ \\
\hline $\begin{array}{l}\text { June } \\
\text { July }\end{array}$ & $\begin{array}{r}1924 \\
17 \\
20 \\
6 \\
11 \\
12 \\
15 \\
18\end{array}$ & $\begin{array}{c}a 34 \\
a 62 \\
28 \\
26 \\
a 25.8 \\
26 \\
24\end{array}$ & $\begin{array}{ll} & 1924 \\
\text { July } & 23 \\
26 & \\
& 30 \\
\text { Aug. } & 2 \\
6 & \\
9 & 9 \\
12 & \end{array}$ & $\begin{array}{l}23 \\
22 \\
21 \\
21 \\
21 \\
20 \\
20\end{array}$ & $\begin{array}{l}1924 \\
\text { Aug. } 15 . \\
16-18 \\
18 \\
23- \\
26 \\
30 \\
\text { Sept. } 2\end{array}$ & $\begin{array}{c}a 20.0 \\
19 \\
52 \\
22 \\
20 \\
19 \\
19\end{array}$ & Sept. $\begin{array}{r}1924 \\
59 \\
13 \\
16 \\
19 \\
22 \\
27\end{array}$ & $\begin{array}{l}19 \\
18 \\
18 \\
70 \\
85 \\
85 \\
84\end{array}$ \\
\hline
\end{tabular}

a Measured. 
TABLE 7.-Records at temporary gaging stations in North Umpqua River BasinContinued

Clearwater River at mouth

\begin{tabular}{|c|c|c|c|c|c|c|c|}
\hline Date & $\begin{array}{l}\text { Dis- } \\
\text { charge }\end{array}$ & Date & $\begin{array}{l}\text { Dis- } \\
\text { charge }\end{array}$ & Date & $\begin{array}{l}\text { Dfs- } \\
\text { charge }\end{array}$ & Date & $\begin{array}{l}\text { Dis- } \\
\text { charge }\end{array}$ \\
\hline $\begin{array}{l}\text { June } 1924 \\
\text { July } 16-\ldots . .\end{array}$ & $\begin{array}{l}\text { a } 216 \\
\text { a } 185\end{array}$ & July $\begin{array}{l}1924 \\
231 \\
31\end{array}$ & $\begin{array}{l}190 \\
180\end{array}$ & Aug. $\begin{array}{l}1924 \\
26 \\
26\end{array}$ & $\begin{array}{l}184 \\
176\end{array}$ & $\begin{array}{l}1924 \\
\text { Avg. } 31 \\
\text { Oct. } 14 \\
\end{array}$ & $\begin{array}{l}170 \\
208\end{array}$ \\
\hline
\end{tabular}

Fish Creek at North Umpqua Trail crossing

\begin{tabular}{|c|c|c|c|c|c|c|c|c|}
\hline $\begin{array}{l}\text { June } \\
\text { July }\end{array}$ & $\begin{array}{l}1924 \\
18 \\
15 \\
18 \\
23 \ldots \ldots \\
24 \ldots \ldots \\
31\end{array}$ & $\begin{array}{c}a 113 \\
a 42.7 \\
42 \\
42 \\
42 \\
35\end{array}$ & 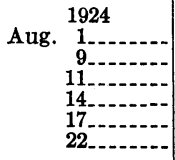 & $\begin{array}{r}35 \\
35 \\
42 \\
\times \quad 32 \\
34 \\
39\end{array}$ & $\begin{aligned} & 1924 \\
& \text { Aug. } 26 \\
& 31 \\
& \text { Sept. } 18 \\
& 21 \\
& 25 \\
& 26\end{aligned}$ & $\begin{array}{l}34 \\
31 \\
25 \\
42 \\
57 \\
35\end{array}$ & $\begin{array}{l}1924 \\
\text { Oct. } 6 \\
9 \\
92 \\
14\end{array}$ & $\begin{array}{l}35 \\
34 \\
35 \\
34\end{array}$ \\
\hline
\end{tabular}

a Measured.

TABLE 8.-Miscellaneous discharge measurements in Umpqua River drainage basin

\begin{tabular}{|c|c|c|c|c|}
\hline Date & Stream & Tributary to- & Loc & $\begin{array}{l}\text { Dis- } \\
\text { charge }\end{array}$ \\
\hline $\begin{array}{l}\text { Apr. } 15,1915 \\
\text { Sept. } 21,1915 \\
\text { Aug. } 15,1915 \\
\text { Sept. } 21,1915 \\
\text { Aug. } 8,1924 \\
\text { Sept. } 12,1924 \\
\text { May } 21,1926 \\
\text { July } 17,1926 \\
\text { Sept. 13,1924 } \\
\text { May 20,1926 }\end{array}$ & 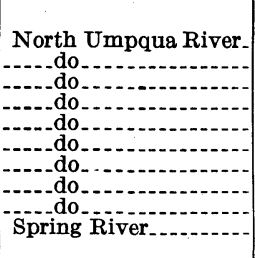 & $\begin{array}{c}\text { Umpqua River } \\
\text { do do } \\
\text { North Ümpqua River }\end{array}$ & $\begin{array}{l}\text { Below Bradley Creek. } \\
\text { Above Lake Creek do do do do } \\
\text { Below Lemolo Falls. do } \\
\text { Near southeast corner sec. 18, } \\
\text { T. } 26 \text { S., R. } 6 \text { E. }\end{array}$ & $\begin{array}{c}\text { Sec. ft. } \\
40 \\
31 \\
269 \\
270 \\
262 \\
251 \\
284 \\
248 \\
306 \\
177\end{array}$ \\
\hline $\begin{array}{l}\text { July } 17,1926 \\
\text { Aug. } 15,1915 \\
\text { Sept. 22,1915 } \\
\text { Aug. 27,1917 } \\
\text { Aug. 14,1915 } \\
\text { Sept. 20,1915 } \\
\text { Aug. 10,1924 } \\
\text { Aug. 15,1915 } \\
\text { Aug. 27, 1917 } \\
\text { Aug. 28, 1915 } \\
\text { Aug. 18,1924 } \\
\text { Oct. 18, 1924 }\end{array}$ & $\begin{array}{l}\text { Lake Creek } \\
\text { do do } \\
\text { Thielsen Creek } \\
\text { Clearwater Riv } \\
\text { do do Creek } \\
\text { do do }\end{array}$ & $\begin{array}{l}\text { do do do } \\
\text { Diamond Lake... } \\
\text { Lake Creek } \\
\text { North Umpqua Ri } \\
\text { do }\end{array}$ & $\begin{array}{l}\text { Outlet of Diamond Lake } \\
\text { Mouth mile above mouth } \\
\text { Trail Crossing, altitude } 4,700 \text { feet } \\
\text { Altitude } 3,700 \text { feet.do } \\
\text { Above Trap Creek, sec. } 1, \mathrm{~T} .27 \\
\text { S., R. 4 E. }\end{array}$ & $\begin{array}{l}174 \\
19.7 \\
21.8 \\
31.8 \\
28.1 \\
23 \\
18 \\
21.5 \\
4.5 \\
172 \\
113 \\
112\end{array}$ \\
\hline $\begin{array}{ll}\text { Aug. } & 14,1925 \\
\text { Oct. } & 10,1925 \\
\text { May } & 20,1926 \\
\text { July } & 18,1926 \\
\text { Aug. } 29,1915 \\
\text { Aug. } 29,1917 \\
\text { June } 19,1924 \\
\text { July } & 16,1924 \\
\text { Aug. } 12,1924\end{array}$ & 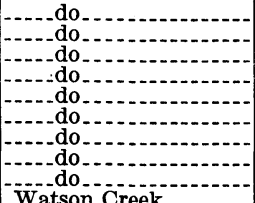 & 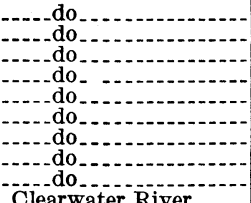 & Mouth & $\begin{array}{l}154 \\
134 \\
151 \\
128 \\
175 \\
174 \\
216 \\
185 \\
184\end{array}$ \\
\hline $\begin{array}{l}\text { Aug. } 28,1917 \\
\text { June } 18,1924 \\
\text { July } 15,1924\end{array}$ & $\begin{array}{l}\text { Watson } \\
\text { Fish Cr }\end{array}$ & $\begin{array}{l}\text { Clearwater River } \\
\text { North Umpqua River- }\end{array}$ & $\begin{array}{l}\text { Trail Crossing, altitude } 3,400 \text { feet } \\
\text { Below Camas Creek }\end{array}$ & $\begin{array}{c}5.9 \\
113\end{array}$ \\
\hline $\begin{array}{l}\text { Aug. } 14,192 \\
\text { July } 13,192\end{array}$ & Steamboat Creek & do & Below Little $\mathrm{R}$ & 32 \\
\hline July 12,1924 & $-d_{0}$ & 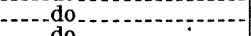 & Sec. 8, T. 25 S., R. 1 E & 22.2 \\
\hline $\begin{array}{l}\text { June } 17,1924 \\
\text { June } 20,1924\end{array}$ & & & $\begin{array}{l}\text { Above Canton Creek } \\
\text { do }\end{array}$ & $\begin{array}{l}33.8 \\
62.5\end{array}$ \\
\hline July 12,192 & & $\cdots 0$ & & 25.8 \\
\hline $\begin{array}{l}\text { Aug. } 15,1924 \\
\text { June } 17,1924\end{array}$ & Canton-- & stean & & \\
\hline Sept. 5,1924 & Rock Creek & North Umpqua Rive & & \\
\hline $\begin{array}{l}\text { Nov. } 4,1910 \\
\text { Aug. } 15,1911\end{array}$ & Little River.......... & - do & & 11 \\
\hline Sept. 6,191 & & & & \\
\hline
\end{tabular}


TABLE 8.-Miscellaneous discharge measurements in Umpqua River drainage basin-Continued

\begin{tabular}{|c|c|c|c|c|}
\hline Date & Stream & Tributary to- & [Locality & $\begin{array}{c}\text { Dis- } \\
\text { charge }\end{array}$ \\
\hline $\begin{array}{lr}\text { Sept. } & 5,1924 \\
\text { Feb. } & 8,1916 \\
\text { July } & 25,1924 \\
\text { July } & 24,1924 \\
\text { Sept. } & 9,1910\end{array}$ & $\begin{array}{l}\text { Little River } \\
\text { Oak Creek } \\
\text { South Umpqua River. }\end{array}$ & $\begin{array}{l}\text { North Umpqua Rfver } \\
\text { Umpqua River. }\end{array}$ & $\begin{array}{l}\text { Mouth } \\
\text { Former Oak Creek post office. } \\
\text { Above Black Rock Creek } \\
\text { Below Quartz Creek. } \\
\text { Above South Fork of South }\end{array}$ & $\begin{array}{c}\text { Sec. }-f t . \\
17.2 \\
101 \\
9 \\
19.5 \\
14.6\end{array}$ \\
\hline $\begin{array}{lr}\text { Nov. } & 10,1910 \\
\text { Aug. } & 10,1911 \\
\text { July } & 12,1924 \\
\text { July } & 26,1924 \\
\text { July } & 28,1924 \\
\text { Aug. } & 9,1915 \\
\text { July } & 24,1924 \\
\text { July } & 25,1924 \\
\text { July } & 26,1924\end{array}$ & $\begin{array}{l}\text { do do do do } \\
\begin{array}{l}\text { Fish Lake Creek } \\
\text { Black Rock Creek } \\
\text { South Fork of South } \\
\text { Umpqua River. }\end{array}\end{array}$ & 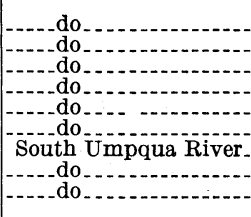 & $\begin{array}{l}\text { Umpqua River, } \\
\text { Above Elk Creek do } \\
\text { Second bridge sourh of Roseburg- } \\
\text { Roseburg } \\
\text { Outlet of Fish Lake } \\
\text { Mouth, in T. } 28 \text { S., R. } 2 \text { E } \\
\text { Mouth. }\end{array}$ & $\begin{array}{r}141 \\
34.8 \\
110 \\
34 \\
54 \\
115 \\
1.5 \\
3.8 \\
14.5\end{array}$ \\
\hline $\begin{array}{l}\text { Aug. } 10,1911 \\
\text { July } 21,1924 \\
\text { July } 7,1924\end{array}$ & $\begin{array}{l}\text { Cow Creek } \\
\text { Elk Creek. }\end{array}$ & $\begin{array}{l}\text { Umpqua River } \\
\text { South Umpqua River- } \\
\text { North Umpqua River- }\end{array}$ & Sec. 21 , T. $32 \mathrm{~S} ., \mathrm{R} .5 \mathrm{~W}$ & $\begin{array}{r}22.2 \\
3.9 \\
4.9\end{array}$ \\
\hline $\begin{array}{lr}\text { Dec. } & 28,1915 \\
\text { Jan. } & 1,1916 \\
\text { Jan. } & 4,1916\end{array}$ & Camp Creek & Mill Creek & $\begin{array}{l}\text { Bridge } 5 \text { miles above mouth } \\
\text { dodo }\end{array}$ & $\begin{array}{r}184 \\
131 \\
87\end{array}$ \\
\hline
\end{tabular}

\section{MAGNITUDE, DURATION, AND FREQUENCY OF FLOODS}

It will be necessary to provide large spillway capacity at all dams in the Umpqua River Basin, as floods are frequent, and the flow on the main branches reaches a great volume. The largest recorded floods at gaging stations are as follows:

TABLE 9.-Maximum recorded discharges in Umpqua River Basin

\begin{tabular}{|c|c|c|c|c|c|}
\hline Stream & Gaging station & Period of record & $\begin{array}{l}\text { Peak dis- } \\
\text { charge }\end{array}$ & $\begin{array}{c}\text { Mean daily } \\
\text { discharge }\end{array}$ & Date \\
\hline Umpqua River........ & Elkton & 1907 to Feb., 1927 & $\begin{array}{l}\text { Sec.-feet } \\
163,000 \\
116,000\end{array}$ & $\begin{array}{l}\text { Sec.-feet } \\
138,000 \\
83,000\end{array}$ & $\begin{array}{l}\text { Nov. } 23,1909 \\
\text { Dec. } 30,1924\end{array}$ \\
\hline $\begin{array}{l}\text { North Umpqua River } \\
\text { Do }\end{array}$ & $\begin{array}{l}\text { Winchester } \\
\text { Oak Creek }-.-\end{array}$ & $\begin{array}{l}1908-1913,1924-1926 \\
1906-1908,1914\end{array}$ & $\begin{array}{r}172,000 \\
92,000 \\
67,900\end{array}$ & $\begin{array}{r}159,000 \\
72,000 \\
58,600\end{array}$ & $\begin{array}{l}\text { Fed. } 21,1927 \\
\text { Nov. 23, } 1909 \\
\text { Feb. } 4,1907\end{array}$ \\
\hline Do & $\begin{array}{l}\text { Rock Creek } \\
\text { Toketee Falls. }\end{array}$ & $\begin{array}{l}\text { Fragmentary records, } \\
\text { 1914-1917, 1925-26. }\end{array}$ & $\begin{array}{l}90,000 \\
37,900\end{array}$ & $\begin{array}{r}70,000 \\
27,400 \\
4,000\end{array}$ & $\begin{array}{l}\text { Dec. } 30,1924 \\
\text { Do. }\end{array}$ \\
\hline South Umpqua River - & Brockway & $1905-1912,1923-1925$ & & $\begin{array}{l}71,000 \\
38,600\end{array}$ & $\begin{array}{l}\text { Nov. } 23,1909 \\
\text { Dec. } 30,1924\end{array}$ \\
\hline
\end{tabular}

astimated.

The peak flow at Elkton in November, 1909, was 25,000 secondfeet greater than the mean for the day, or 6.8 second-feet to the square mile; in February, 1927, the peak flow was 15,000 second-feet greater than the daily mean. At the gaging station above Rock Creek the peak flow in December, 1924, was 10,500 second-feet greater than the mean for the day, or 11.9 second-feet to the square mile.

The distance by river from the gaging station near Elkton to Glide is 88 miles and to the Rock Creek dam site 96 miles. Floods 
on the Colorado River travel downstream at a rate of 12 to 15 miles an hour and possibly at times exceed 20 miles an hour. At 12 miles an hour the floods would travel from Rock Creek to the gaging station near Elkton in eight hours. As the fall per mile averages higher on the North Umpqua River than on the Colorado River below Lees Ferry, Ariz., it seems safe to assume that floods would travel downstream at a rate as great as ordinary floods on the Colorado River. The records at the gaging stations confirm these conclusions, as high water seems to occur on the same day near Glide on the North Umpqua River, on the South Umpqua River near Brockway, and on the Umpqua River near Elkton. A flood at Elkton would probably mean a flood at Glide on the same day, and owing to the small size of the basin a high flood probably would not occur at Elkton, except through general flood conditions over the basin. In November, 1909, when the mean daily discharge near Elkton amounted to 138,000 second-feet, 71,000 second-feet came from the South Umpqua River and about 72,000 second-feet from the North Umpqua River above Winchester. The total estimated discharge of the North Umpqua and South Umpqua Rivers therefore exceeded the estimated mean daily flow at Elkton by 5,000 secondfeet, but this is a negligible error, which may be due to a lack of continuous gage-height records at the three stations. The peak flow at Winchester during the flood of November 23, 1909, amounted to 71 second-feet to the square mile.

On the South Umpqua River at Brockway records are available for eight years, but they include what was probably the greatest flow in a 20-year period.

Between Rock Creek and Toketee Falls safe estimates of flood discharge can be obtained on the basis of comparative drainage areas, but this method will probably give results that are too high, especially above the mouth of Steamboat Creek. At and above Toketee Falls comparatively low diversion dams are proposed in this report and no trouble should be experienced from floods. On the South Umpqua River comparisons based on drainage areas will probably give figures for flood flows that will be slightly low.

\section{PRIOR WATER RIGHTS}

The State uses Diamond Lake in connection with a fish hatchery near the outlet-the only prior right to the water of the North Umpqua River above Glide. There are no known diversions for irrigation from the North Umpqua River or the Umpqua River, but there are small diversions from the tributaries. Calapooya Creek, tributary to the Umpqua River, is practically all diverted for irrigation during the summer. A power plant of the California- 
Oregon Power Co. at Winchester uses the entire low-water flow of the North Umpqua River and therefore has established rights in this water.

On the South Umpqua River some water is diverted from the main river by pumping. Cow Creek is almost entirely used for irrigation, and there are undoubtedly diversions from the other tributaries below Tiller. Above Tiller there are no known diversions or established rights.

\section{RIVER CONTROL}

The Umpqua and North Umpqua Rivers have a well-sustained low-water discharge, but there is a long period of comparatively low flow, when auxiliary power or storage will be required to carry the load that can ordinarily be carried by natural flow during eight or nine months of the year. During periods when the natural flow would not supply the power plants any water obtained from storage could be used to generate power at no additional cost except that for storing it, and of course the more plants this stored water can pass through the greater its value. For this reason water stored in Diamond Lake would have greater power value than water stored at sites lower down, as it could be used at all plants on the North Umpqua and Umpqua Rivers. The water supply for Diamond Lake is not great, but storage will be inexpensive.

There are no other large reservoir sites except Coles Valley. This site is discussed in detail on page 250 , but it lies at a low altitude, and the lands that would be flooded are valuable for agriculture, so that the cost per horsepower-year would be high. Some regulation can be provided at the proposed dams above Coles Valley, but not nearly enough storage is available to equalize the annual flow, even in a low year. At all proposed reservoirs on the North Umpqua and Umpqua Rivers there would be a loss of head due to drawdown. As the flow for 90 per cent of the time amounts to 775 second-feet at Soda Springs and is even greater at all other sites lower down, it is apparent that if the period of drawdown exceeds four months this loss of power will be very considerable. In fact, in most places the loss of power due to loss of head will exceed the power obtained from the stored water if the sites are considered individually, and it is only by assuming that the stored water will be used at a number of sites that drawdown for over two months ean be justified. At some sites, notably at Soda Springs, it is proposed to develop the power by high dams rather than by conduits because of the storage that can be obtained by drawing down the head. Detailed studies at the time of development will be necessary to determine whether the additional 
power obtained from the stored water will justify the added cost of a high dam over development by conduit.

At Coles Valley if it were not for the storage feature the head would be developed by a series of low dams rather than by the one high dam; so this is primarily a reservoir site. At this site the storage capacity is so great that the loss of power due to loss of head is small compared with the power obtained from the stored water, and the period of drawdown can be extended over a period of six months without serious loss of power due to loss of head.

On the South Umpqua very little power is available without storage. Two fair reservoir sites are available below Tiller, but the land is valuable, a rather long dam would be required in each place, and the flow of the South Umpqua is not so great or so well sustained as the flow of the North Umpqua. The valley of the South Umpqua River is agricultural, but it usually receives enough rainfall to supply the prune orchards, and there is not much demand for water for irrigation, so that reservoirs for irrigation are not justified under present conditions.

\section{STORAGE SITES}

\section{DEVELOPED SITES}

There are no developed storage sites in the Umpqua River Basin, except possibly very small reservoirs for irrigation.

\section{UNDEVELOPED SITES}

Some of the proposed storage in the Umpqua River Basin will be obtained at power dams by drawing down the head. In general it has been assumed that the head at sites on the upper tributaries will be drawn down first. Also the storage was assumed to be manipulated in 1925 and in 1926 so as to give a fairly uniform output of power for the whole system of plants on the Umpqua and North Umpqua Rivers. In Table 10 the value of the reservoirs is given in millions of kilowatt-hours on the basis of no loss of head except at the sites considered. This amount represents the maximum powei obtainable from the stored water. The net gain in power on the basis of a uniform power output for the system in 1926 is also given an. represents the minimum value of the site. The latter amount represents a fair value for the storage in a power system largely supplied with water power. In a large system, with considerable power obtained from auxiliary steam, it would be possible to operate the plants so as to come somewhere between the two estimates, probably approaching the larger one. 


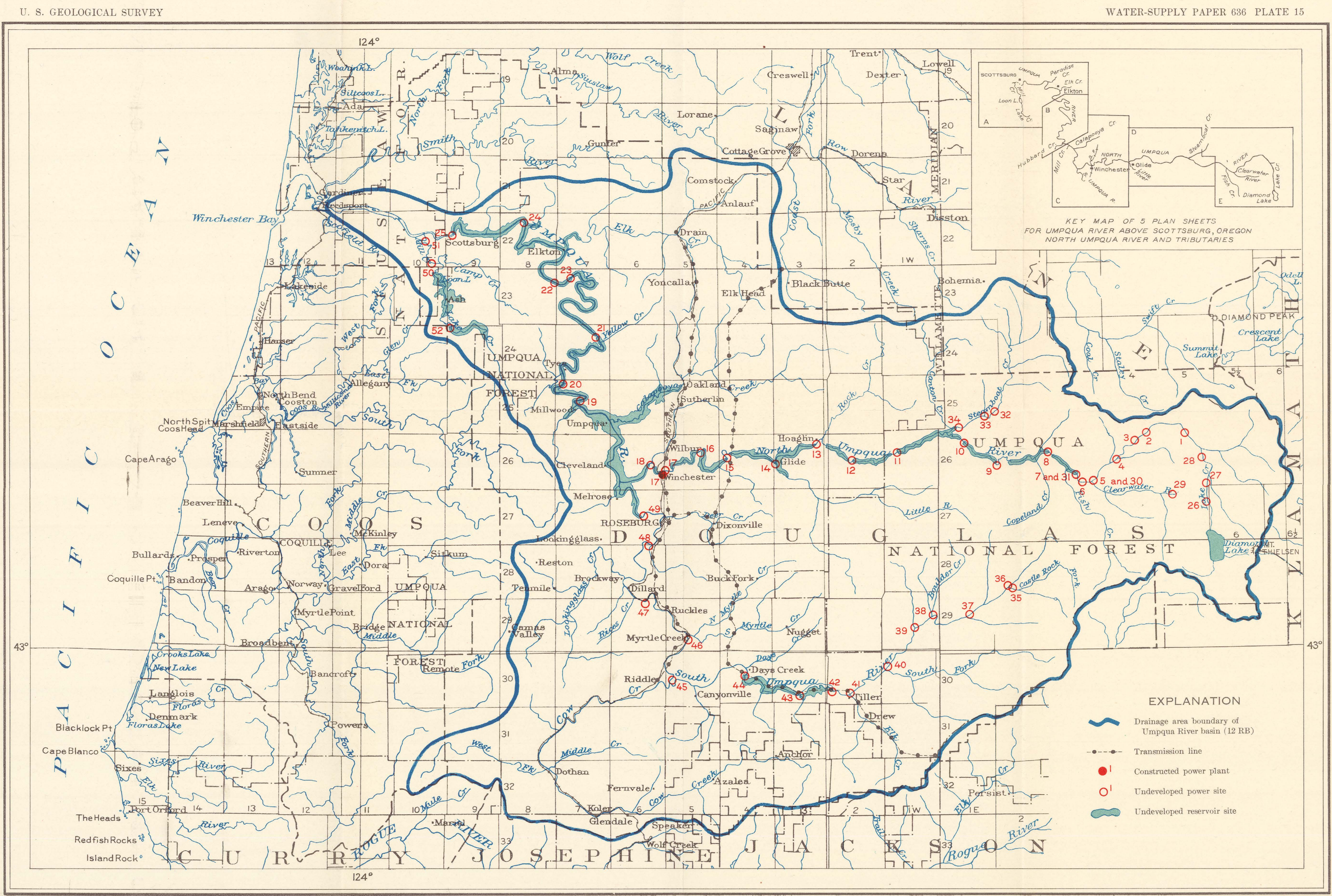

MAP OF SOUTHWESTERN OREGON SHOWING PROPOSED POWER SITES IN UMPQUA RIVER BASIN 


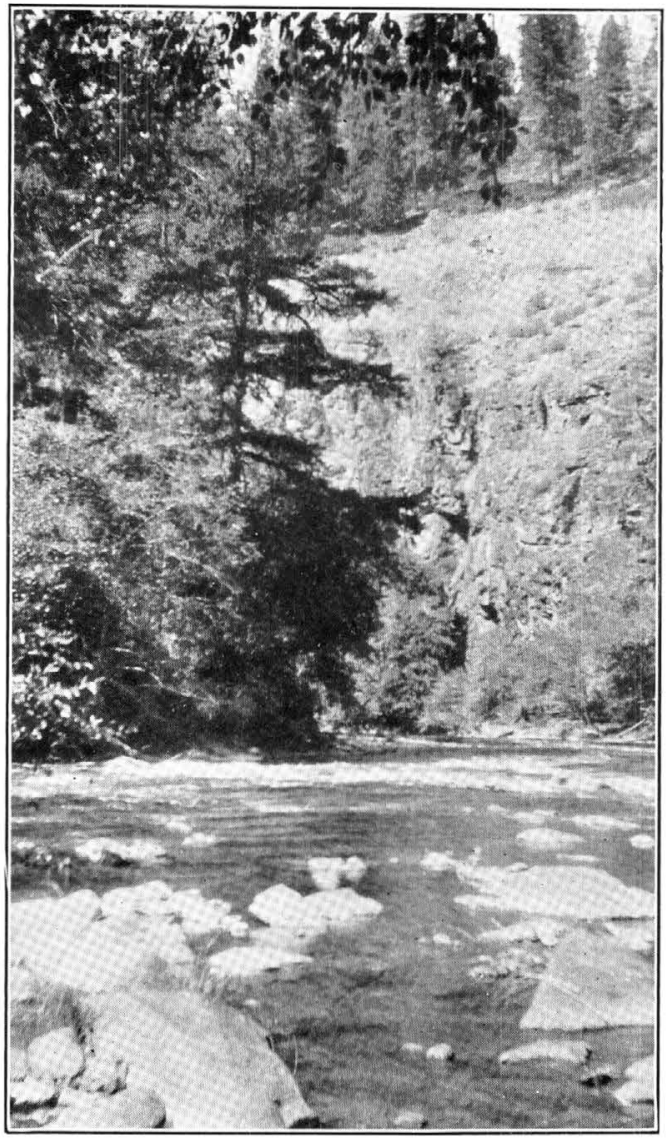

A. RIGHT BANK AT COPELAND CREEK DAM SITE, UMPQUA RIVER BASIN

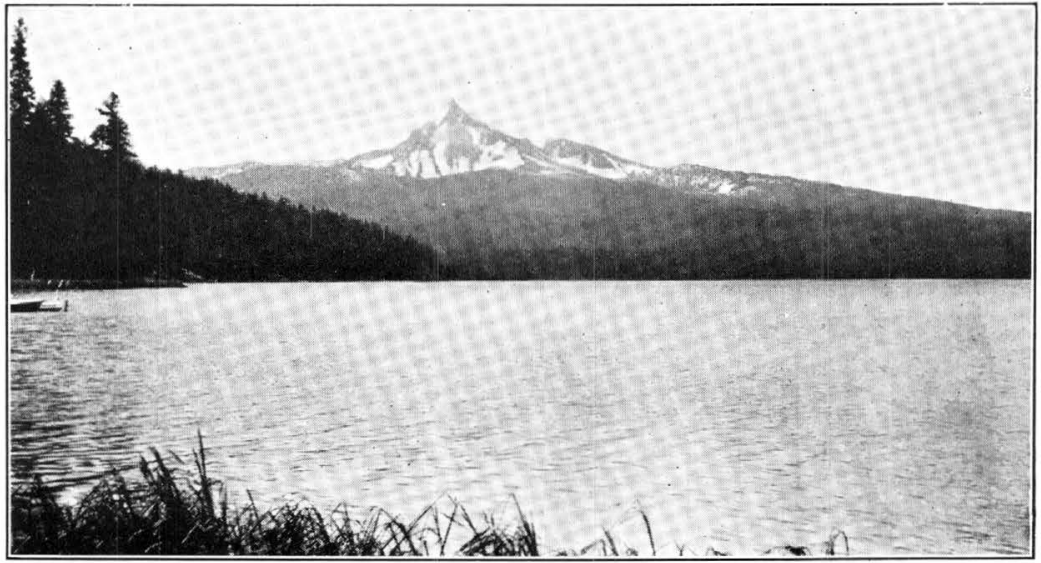

B. DIAMOND LAKE AND MOUNT THIELSEN, UMPQUA RIVER BASIN 


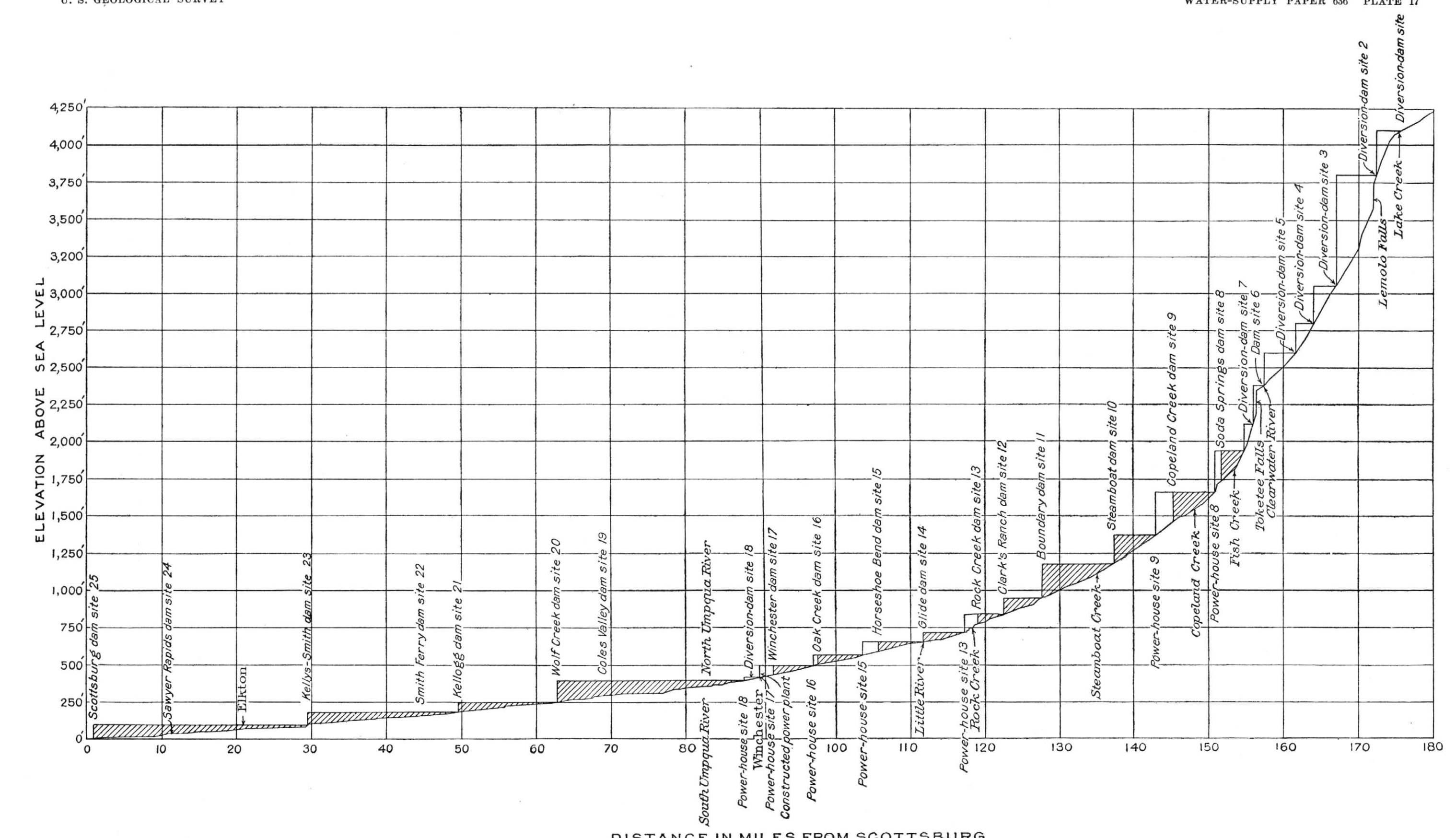

DISTANCE IN MILES FROM SCOTTSBURG

PROFILE OF UMPQUA AND NORTH UMPQUA RIVERS, SHOWING LOCATION OF DAM SITES 

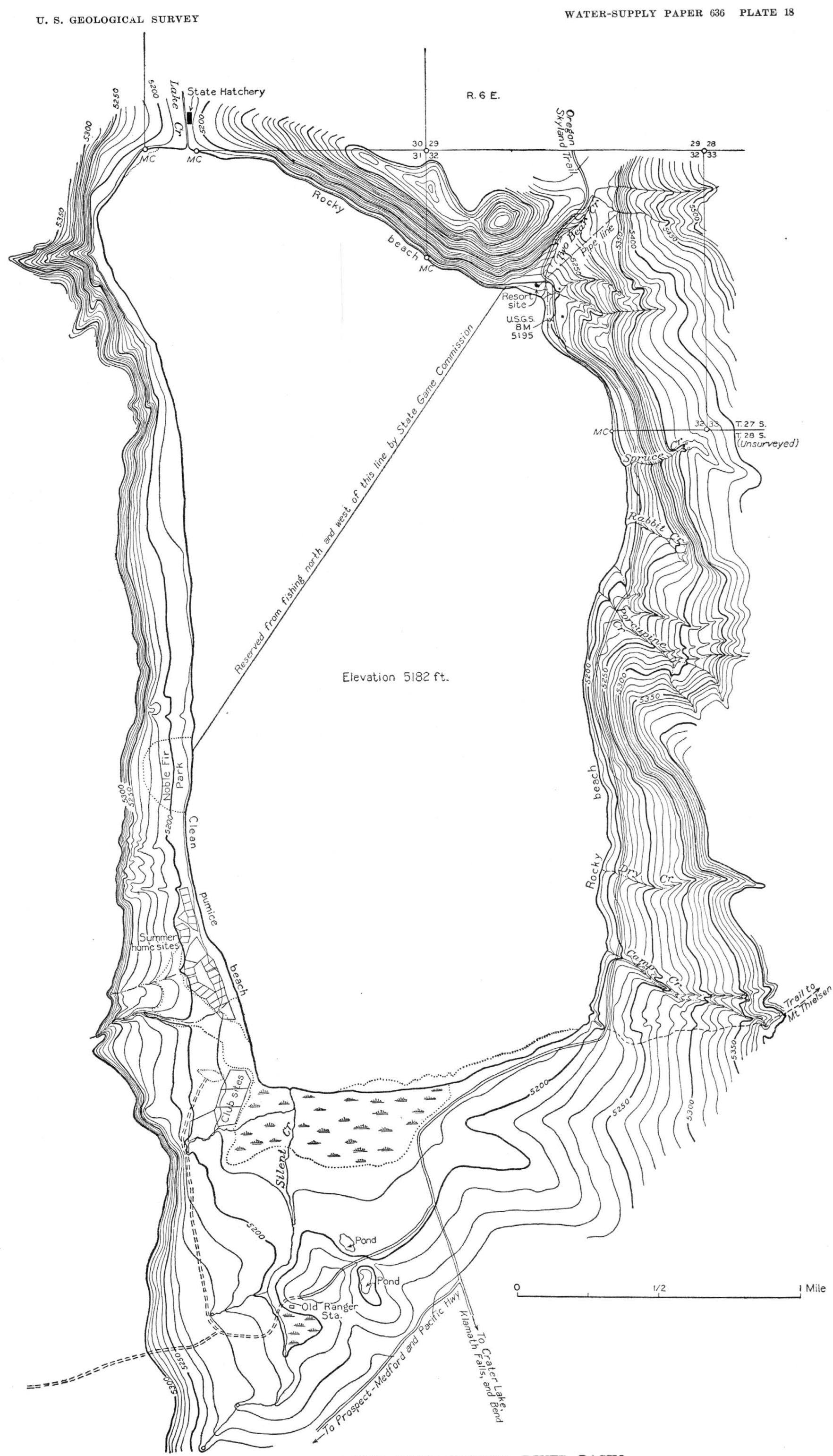

PLAN OF DIAMOND LAKE, UMPQUA RIVER BASIN

From map prepared by U. S. Forest Service. 
Table 10 presents a summary of the principal features of proposed reservoir sites in the Umpqua River Basin and of the storage which can be obtained by drawing down the head above dams built primarily for power. The first six sites will be operated primarily as storage sites; the others will be used for power with storage as a secondary feature. The first six sites are therefore discussed under undeveloped reservoir sites, and the power that can be obtained by drawing down the head at other sites has been discussed in connection with the power. 
TABLE 10.-Proposed reservoir sites in Umpqua River Basin

Sites used primarily for storage

\begin{tabular}{|c|c|c|c|c|c|c|c|c|}
\hline Index No. & Name & Stream & Full head & $\begin{array}{l}\text { Draw- } \\
\text { down }\end{array}$ & $\begin{array}{c}\text { Storage made } \\
\text { available }\end{array}$ & $\begin{array}{c}\text { Gross } \\
\text { head at } \\
\text { plants } \\
\text { below } \\
\text { reservoir }\end{array}$ & $\begin{array}{c}\text { Gross gain in } \\
\text { power at all } \\
\text { sites }\end{array}$ & $\begin{array}{l}\text { Net gain in } \\
\text { power at all } \\
\text { sites }\end{array}$ \\
\hline $\begin{array}{l}\text { 12RB } 26 \\
\text { 12RB } 19,20 \\
\text { 12RB } 35 \\
\text { 12RB } 43 \\
\text { 12RB } 50 \\
\text { 12RB } 52\end{array}$ & $\begin{array}{l}\text { Diamond Lake } \\
\text { Wolf Creek or Coles Valley } \\
\text { Fish Lake } \\
\text { Perdue } \\
\text { Days Creek } \\
\text { Loon Lake } \\
\text { Lake Creek. }\end{array}$ & $\begin{array}{l}\text { Lake Creek } \\
\text { Umpqua River } \\
\text { Fish Lake Creek } \\
\text { South Umpqua River. } \\
\text { Mild Creek. } \\
\text { Lake Creek }\end{array}$ & $\begin{array}{c}\text { Feet } \\
10.3 \\
145 \\
1.264 \\
100 \\
100 \\
385 \\
127\end{array}$ & $\begin{array}{l}\text { Feet } \\
10.3 \\
80 \\
40 \\
80 \\
80 \\
71 \\
75\end{array}$ & $\begin{array}{r}\text { Acre-feet } \\
30,000 \\
422,000 \\
4,500 \\
37,600 \\
60,000 \\
\quad 100,000 \\
45,000\end{array}$ & $\begin{array}{r}\text { Feet } \\
5,120 \\
374 \\
3,308 \\
920 \\
820 \\
445 \\
494\end{array}$ & \begin{tabular}{|c|}
\multicolumn{2}{|c|}{ Millions of } \\
kilowatt-hours \\
111 \\
114 \\
11 \\
25 \\
35 \\
28 \\
b 16
\end{tabular} & $\begin{array}{c}\text { Millions of } \\
\text { kilowatt-hours } \\
107 \\
113 \\
10 . \\
23 . \\
34 \\
28 \\
\text { b } 16\end{array}$ \\
\hline
\end{tabular}

Sites used primarliy for power

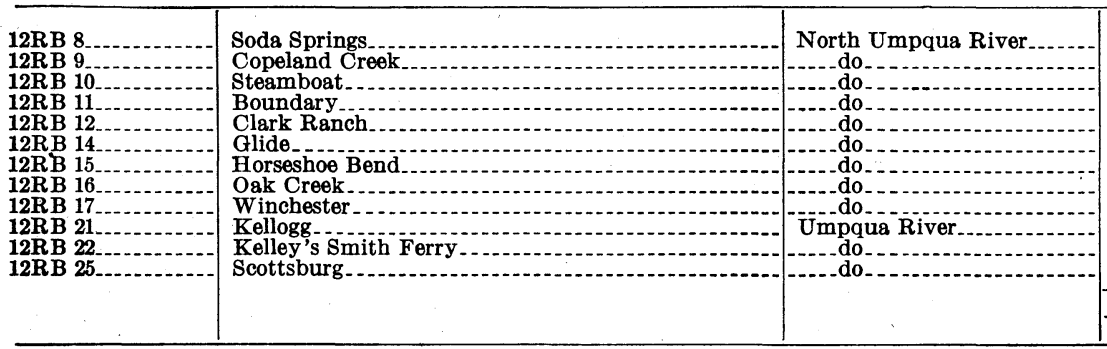

a In low year 85,000 acre-feet available for storage.

\begin{tabular}{r|r|r|r|r|r}
275 & 80 & 14,700 & 1,895 & 20 & 12.5 \\
290 & 85 & 24,800 & 1,618 & 28 & 19 \\
190 & 75 & 19,000 & 1,330 & 18 & 11 \\
225 & 100 & 62,000 & 1,132 & 51 & 36 \\
110 & 35 & 16,000 & 935 & 11 & 7 \\
60 & 20 & 14,000 & 713 & 7 & 3.5 \\
90 & 21 & 16,000 & 651 & 7.5 & 4 \\
70 & 20 & 14,000 & 561 & 5.5 & 3 \\
80 & 25 & 12,000 & 489 & 4 & 2 \\
70 & 25 & 21,000 & 244 & 3.5 & 2 \\
85 & 45 & 58,000 & 165 & 7.5 & 4 \\
100 & 40 & 120,000 & 84 & 7.0 & 4 \\
\hline & & $1,090,600$ & -1 & 494 & 424 \\
\hline
\end{tabular}

b Not included in total. 


\section{DIAMOND LAKE RESERVOIR ETTE (12RB 26)}

Diamond Lake, at the head of Lake Creek, has an area of about 2,910 acres. (See pls. 16, B, and 18.) There is good fishing in the lake, the water is warm enough to permit swimming, and there are several excellent camp sites along its shores. Diamond Lake should therefore be used for recreation.

The United States Forest Service is developing the lands around the lake as a summer resort, having reserved sites for cottages, tourist camps, and a hotel. Few buildings have been constructed, however, and if they are kept at a height of at least 8 feet above the low-water level of the lake they should not interfere with the use of the lake for storage of water. On the other hand, if the lake is maintained within a foot or two of the ordinary level during July and August, its use for storage should not interfere with its use for recreation. Crater Lake National Park does not open usually until July, because of the snow, and there are not many campers at this altitude after September 1.

No records of the run-off of Diamond Lake for the winter are available, but from fragmentary records it seems probable that the ordinary yearly run-
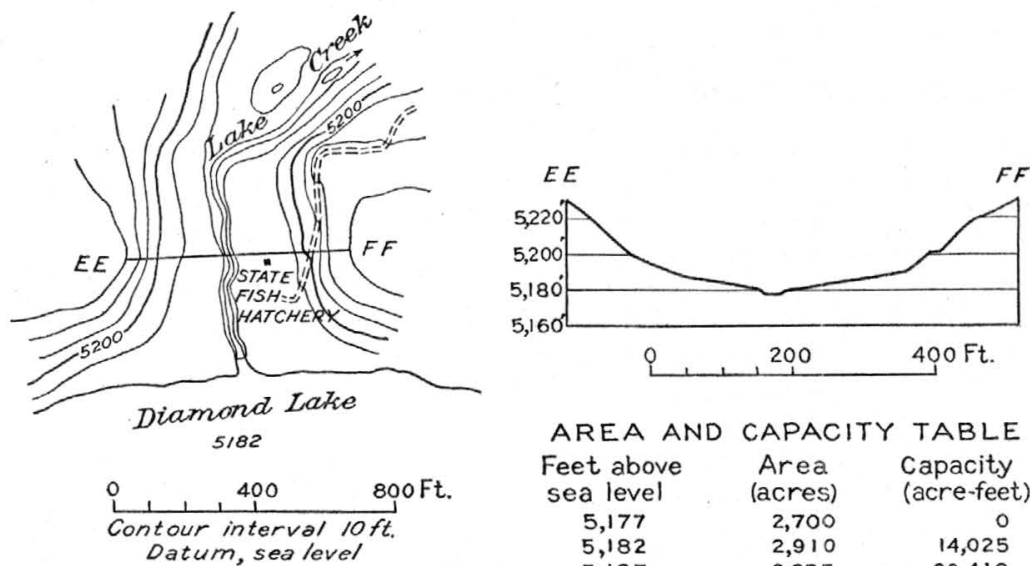

$\begin{array}{ccc}\text { AREA AND } & \text { CAPACITY TABLE } \\ \text { Feet above } & \text { Area } & \text { Capacity } \\ \text { sea level } & \text { (acres) } & \text { (acre-feet) } \\ 5,177 & 2,700 & 0 \\ 5,182 & 2,910 & 14,025 \\ 5,187 & 3,235 & 29,412 \\ 5,190 & 3,431 & 39,411\end{array}$

Figure 14.- Plan and cross section of Diamond Lake dam site, Umpgua River Basin

off amounts to 50,000 acre-feet, and in a dry year this is reduced to about 30,000 acre-feet. If necessary, part of the flow of Thielsen Creek could be diverted to Diamond Lake by building 2 miles of canal.

A variation of 10.3 feet in the altitude of the water surface of the lake would permit the storage of the entire flow in a low year. This could be done partly by raising and partly by lowering the normal altitude of the lake. Raising the lake 5.3 feet would interfere very little with its use for recreation, as most of this water could be used before the middle of July. Then during September and October it could be dropped 5 feet. In this way 30,000 acre-feet of water would be available for use for power, and yet the lake surface would be at normal stage during July and August, the months of greatest use for recreation. The cost of the work necessary to regulate the lake within these limits would be negligible, the damage would be slight, and yet when all the sites on the North Umpqua and Umpqua Rivers are developed this water would generate $84,000,000$ kilowatt-hours at almost no extra cost, if there were no drawdown at lower sites, or $80,000,000$ kilowatt-hours after allowance is made for this drawdown. If sites on Lake Creek are included, the total gain would 
be $111,000,000$ kilowatt-hours, and the net gain would be 107,000,000 kilowatthours. The machinery would be available, the operators would be at work, and no extra labor would be required to run this stored water through the wheels.

The value of Diamond Lake for storage of water can be estimated from the figures above given for potential power by assuming a value for 1 kilowatthour. In other words, the people of Oregon and California, where the power is sold, will pay considerably less yearly for power if the lake can be raised 5 feet above normal in the spring and dropped 5 feet below normal in the fall. Of course a greater variation would produce more storage and make the lake more valuable for power. But this increase, would not increase the power available in the same proportion as the first 10 feet, because in some years the water supply would be deficient, and the effect on the recreational use of the lake would be harmful. It is not certain that a variation of 10 feet would prove the most beneficial for generating power and at the same time preserving the recreation value. Records of winter flow and a careful survey of the shore for 10 feet above and below the normal water level will provide a basis for determining the most beneficial plan of procedure.

\section{COLES VALLEY OR WOLF CREEK RESERVOIR SITE (12RB 19 AND 20)}

The Coles Valley or Wolf Creek reservoir site can be developed by a dam at either the Wolf Creek dam site, in sec. 6, T. 25 S., R. 7 W., or the Coles Valley dam site, in sec. 16, T. 25 S., R. 7 W. (See figs. 15 and 16.) The Wolf Creek site is preferable, as the amount of storage per acre overflowed will be greater, and in the study of the power and storage possibilities of the two sites it has been assumed that the Coles Valley Reservoir will be created by a dam at the Wolf Creek site. The geology at these two dam sites is described in connection with the Coles Valley and Wolf Creek power sites.

A dam at the Wolf Creek dam site to raise the water level to the 400 -foot contour would afford a reservoir capacity of 422,000 acre-feet, with a drawdown of 80 feet. A good idea of the value of the reservoir can be obtained from the power that could be generated by the stored water. The average head at the Wolf Creek dam would be $\mathbf{1 1 9}$ feet, and at the four sites below an additional head of 255 feet could be used, or 374 feet in all. The total power available from 422,000 acre-feet of water, used through a head of 374 feet, is $114,000,000$ kilowatt-hours. If it is assumed that the power which would be obtained from the natural flow would pay for the dams, power houses, transmission lines, and any flowage at sites below Coles Valley, then the total annual revenue received from $114,000,000$ kilowatt-hours could be capitalized and used to pay for flowage rights in the Coles Valley Reservoir. The total area that would be overflowed if the area were flooded to an altitude of 400 feet is 12,750 acres.

A dam to flood the area to the 380-foot contour, with a drawdown of 70 feet, would afford 228,000 acre-feet of storage. This water could be used under an average head of 104 feet at the Wolf Creek site and through a total head of 359 feet, yielding $59,000,000$ kilowatt-hours. The area of such a reservoir would be 63 per cent of that of the larger reservoir, and the value of the storage would be 52 per cent of the value of the storage in the larger reservoir.

A dam built to an altitude of 360 feet would overflow 4,600 acres and afford 97,000 acre-feet of storage with a drawdown of 50 feet. This stored water could be used through an average head of 88 feet at the Wolf Creek site and through a total head of 343 feet and would generate 24,000,000 kilowatt-hours. 
The cost of storage at this site will be high, owing to the valuable agricultural land overflowed, the length of dam required, and the comparatively small amount of fall in the river between the dam site and tidewater.
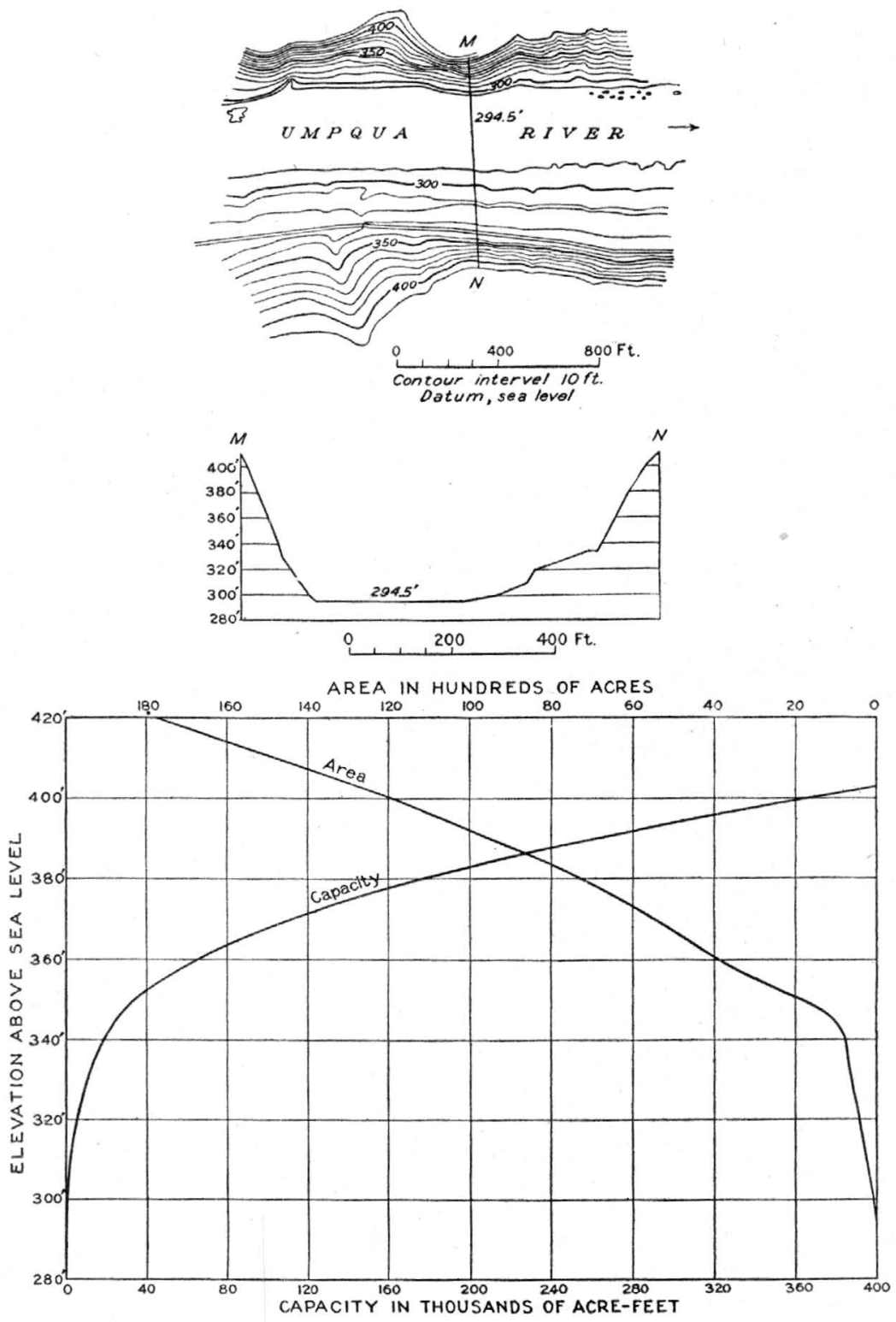

Figure 15.-Plan, cross section of dam site, and area and capacity curves, Coles Valley reservoir site, Umpqua River Basin

FISH LAKE RESERVOIR SITE (12RB 35)

Fish Lake, in secs. 5 and 6, T. 29 S., R. 3 E., has a surface area of about 100 acres. The lake is probably formed by a slide at the outlet, but conditions $47154^{\circ}-30-17$ 
appear good for a rock or earth-fill dam. A dam 40 feet high at the outlet would be about 150 feet long on top and would create a reservoir with a capacity of about 4,500 acre-feet. Very little is known of the run-off, but the precipitation must be fairly high at this altitude, which is about 3,400 feet above sea level. It is roughly estimated that with 4,500 acre-feet of storage capacity the flow could be regulated to provide a continuous discharge of 15 second-feet.

\section{PERDUE RESERVOIR SITE (12RB 43)}

The dam site for the Perdue Reservoir is just below the post office of Perdue, in sec. 34 , T. 30 S., R. 3 W. Bedrock is exposed in the river channel and on
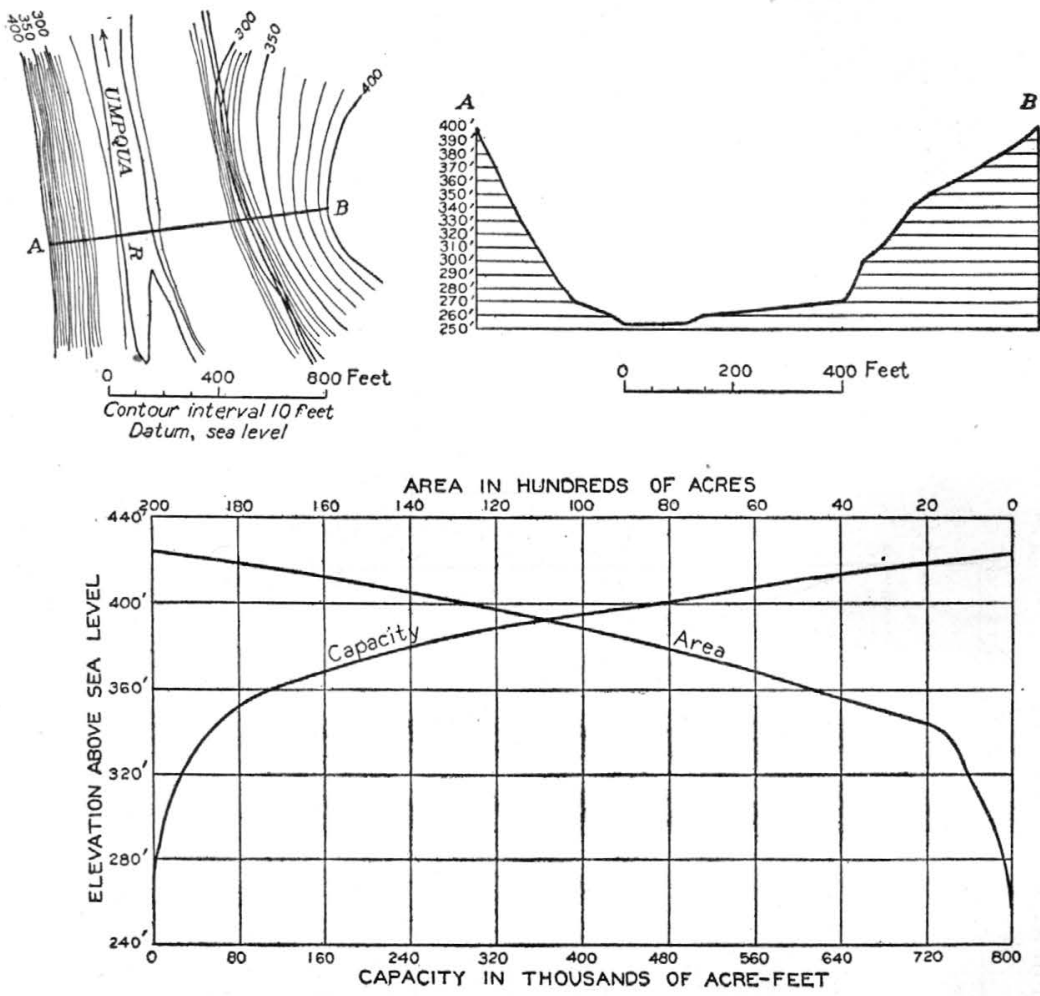

Figure 16.-Plan, cross section of dam site, and area and capacity curves, Wolf Creek reservoir site, Umpqua River Basin

both banks. A dam 100 feet high is proposed which would raise the water surface to an altitude of 1,000 feet above sea level and would flood about 940 acres. No accurate map of the reservoir is available, but on the assumption that the river channel is 20 feet deep and that a dam 100 feet high would cover the reservoir to an average depth of 40 feet, the capacity would be 37,600 acrefeet. This amount of storage would afford a minimum flow of 200 second-feet in an average year, if the flow at the Perdue Reservoir site is taken as onethird of the flow at the gaging station at Brockway, this being the ratio of the drainage areas. The flow at Perdue probably averages 50 second-feet more than one-third of the flow at 3rockway during periods of low water, and the average low-water flow with regulation at this site is estimated at 250 second- 
feet. In 1911, the only year for which stream-flow records at Tiller are available and a year of normal run-off, a minimum flow of 265 second-feet could have been maintained with the storage assumed to be available.

The average head for power at Perdue would be about 65 feet if the reservoir were drawn down 80 feet for the storage. The potential power with 250 secondfeet of water and 65 feet of head is 1,300 horsepower. The average flow without storage during the time the reservoir would have been drawn down in 1911 would have been about 104 second-feet. With 100 feet of head this would yield 830 horsepower. The gain from using the stored water would be 470 horsepower for about 125 days. The real gain from storage would come from sites lower down. On the South Umpqua River a total head of $\mathbf{4 2 0}$ feet could be obtained at sites that are not very attractive under present conditions. But on the Umpqua River a total head of 350 to 400 feet could be obtained at sites where plants will probably be built. The head is uncertain, because the water level will be drawn down at times for the sake of storage. The 37,600 acre-feet of water that could be stored in the Perdue Reservoir, if used at proposed plants on the Umpqua River, would yield 9,000,000 kilowatt-hours. There would be no operating costs in connection with the use of this water, because it is assumed that the plants on the Umpqua River would be built to a capacity greatly exceeding the low-water flow and would be operating whether or not the Perdue Reservoir were built. There would thus be no added cost for running this stored water through the wheels, and as it would take the place of stand-by steam power it might well be worth more than the price of ordinary year-round power.

In addition to the power obtained from the stored water by using it in plants on the Umpqua River there would be an average of 1,300 horsepower available at the dam during the summer and considerably more during the eight months of high run-off ; 1,300 horsepower is equivalent to $8,000,000$ kilowatt-hours a year. Also the Days Creek site on the South Umpqua River is probably financially feasible in connection with other sites, and the water from the Perdue Reservoir would produce 2,500,000 kilowatt-hours at that site. The area of the reservoir is 900 acres, mostly poor agricultural land, and the damage to lands and improvements should not amount to more than $\$ 200$ an acre. This project may therefore be feasible after the construction of the plants on the Umpqua River.

The sites on the South Umpqua, except the reservoir sites at Perdue and above Days Creek, are not attractive and would not be developed unless the low-water flow could be increased by storage at Perdue and Days Creek with none of the cost of this storage charged to the plants on the South Umpqua. The total net head at proposed sites on the South Umpqua River below the Perdue Reservoir is 420 feet. With this head and a low-water flow of 250 second-feet, 8,400 continuous horsepower could be generated. If the reservoirs at Perdue and Days Creek are built the sites lower down on the South Umpqua River will undoubtedly be developed. This power on the South Umpqua River below Days Creek should therefore for statistical purposes be considered a part of that made available by the reservoir, but in estimating the financial feasibility of the reservoirs the proposed plants on the South Umpqua River can be disregarded.

\section{DAYS CREER RESERVOIR SITE (12RB 44)}

The dam site for the Days Creek Reservoir is about $11 / 4$ miles above Days Creek, in sec. 16, T. 30 S., R. 4 W. A dam 100 feet high, which would back water to the Perdue dam site, is proposed. The dam site is not particularly 
good, as the dam would be about 1,000 feet long. The area of the reservoir would be 1,500 acres, and at an average depth of 40 feet the capacity would be about 60,000 acre-feet. This amount of storage would afford a minimum flow of 270 second-feet if the discharge at the reservoir is as estimated from the flow at Brockway on the basis of comparative drainage areas. The actual low-water flow is believed to be about $\mathbf{5 0}$ second-feet more than that indicated by comparison of drainage areas, and so the flow regulated by the Days Creek Reservoir alone would be 320 second-feet. The average head would be about 65 feet, and the power capacity 1,660 horsepower. This capacity would not justify the construction of the reservoir and plant, but the stored water could also be used on the Umpqua River through a head of about 350 feet at plants that will probably be constructed regardless of any storage on the South Umpqua River. With this head 60,000 acre-feet of water would generate $15,000,000$ kilowatt-hours. There would also be 1,660 horsepower available at the dam, which in a year would amount to $11,000,000$ kilowatt-hours. The area overflowed would be 1,500 acres. Some of this area is fruit land, and the average cost might run to $\$ 400$ an acre, or a total of $\$ 600,000$. But most of the power would be available during the low-water season and would take the place of steam stand-by power. Its value might therefore be sufficient to make the project financially feasible. The water stored in this reservoir could also be used at proposed power sites lower down on the South Umpqua River, where a total head of 355 feet would be available. But these sites would be expensive to develop, would not be financially feasible without storage, and yet would not be able to pay the cost of storage. The potential power at these sites, if the flow were regulated by the Days Creek Reservoir, would be 9,070 continuous horsepower.

If the Perdue and Days Creek Reservoirs were both constructed the lowwater flow could be increased to $\mathbf{3 7 5}$ second-feet if, as assumed, flow is one-third that at Brockway. To this amount should be added about 50 second-feet to allow for the fact that the flow at Perdue and Days Creek is somewhat more than that obtained by using the drainage area ratio of 1 to 3 . If the Fish .Lake Reservoir were constructed it would add very little to the regulated flow below Days Creek, and it may be disregarded.

\section{LOON LAKE RESERVOIR SITE (12RB 50) AND LAKE CREER RESERVOIR SITE} (12RB 52)

The alternative sites of the Loon Lake and Lake Creek Reservoirs (see pl. 15) are considered together for purposes of comparison. Both are in the Mill Creek Basin. Two general schemes are possible for the utilization of the water power of Mill Creek, one through the development of the Loon Lake Reservoir and the other through the development of a smaller reservoir near the headwaters of Lake Creek above Loon Lake, where land values are not so high. (See figs. 17-19 and pl. 19, A.)

For the five years for which complete records are available the average an. nual run-off at the gaging station below Loon Lake was 217,000 acre-feet, equivalent to a continuous flow of 300 second-feet. The maximum annual run-off for this period was 239,000 acre-feet; the minimum was 192,000 acre-feet.

Because of the small drainage area floods need not be considered as affecting power schemes. No water is diverted for irrigation or other purposes.

The Loon Lake site was surveyed in 1924 to the 460 -foot contour, and the dam site to the 480-foot contour. The basin of Mill Creek above the Loon Lake dam site has an area of 84 square miles. The following table shows the stor- 
age capacities at the Loon Lake site that would be necessary to control the annual run-off for the periods of the record:

Storage required at Loon Lake to equalize the mean annual flow for years of record

Period

Dec. 1,1907 , to Nov. 30, 1908

Dec. 1, 1908, to Oct. 31,1909

Nov. 1,1909 , to Oct. 31,1910

Nov. 1, 1910 , to Oet. 31,1911

Nov. 1, 1915, to Nov. 30, 1916

\begin{tabular}{|r|r|r}
$\begin{array}{c}\text { Number } \\
\text { of } \\
\text { months }\end{array}$ & $\begin{array}{c}\text { Mean } \\
\text { discharge }\end{array}$ & $\begin{array}{c}\text { Storage } \\
\text { required } \\
\text { to main- } \\
\text { tain mean }\end{array}$ \\
\hline & & \\
& Sec.-ft. & $\begin{array}{r}\text { Acre-feet } \\
86,000 \\
11\end{array}$ \\
12 & 321 & 117,000 \\
12 & 333 & 120,000 \\
13 & 263 & 85,000 \\
& 422 & 162,000 \\
\hline
\end{tabular}
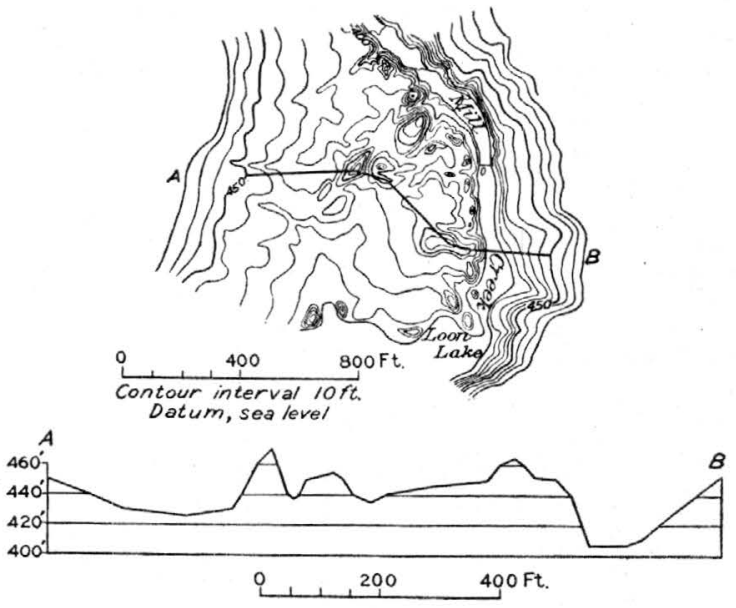

AREA IN HUNDREDS OF ACRES

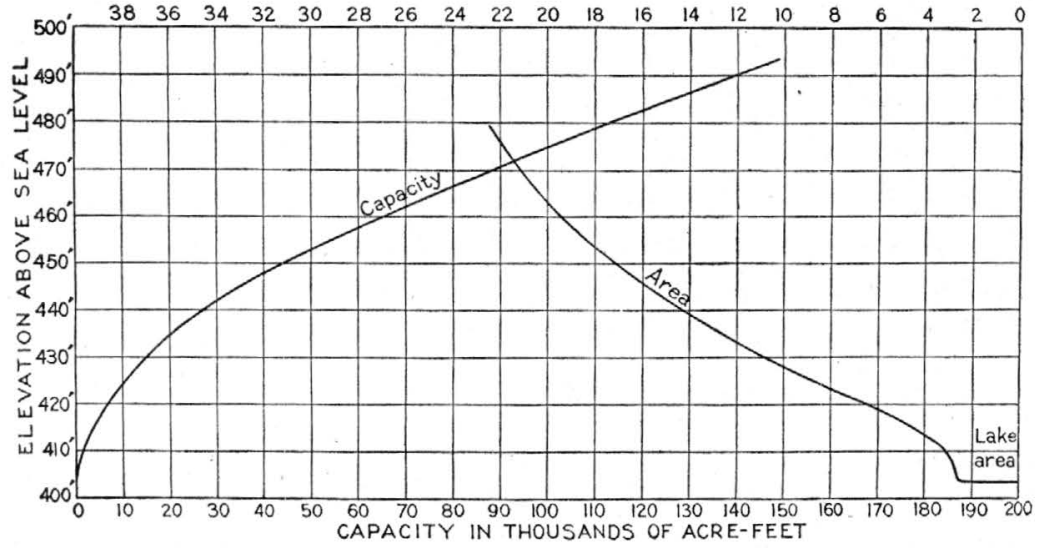

FIgURE 17.-Plan, cross section of dam site, and area and capacity curves, Loon Lake reservoir site, Umpqua River Basin 
Of the two sites the lower, or Loon Lake site, would obviously control the greater amount of run-off, but its great disadvantage is the large area of valuable agricultural land that would be flooded. In view of the damage from
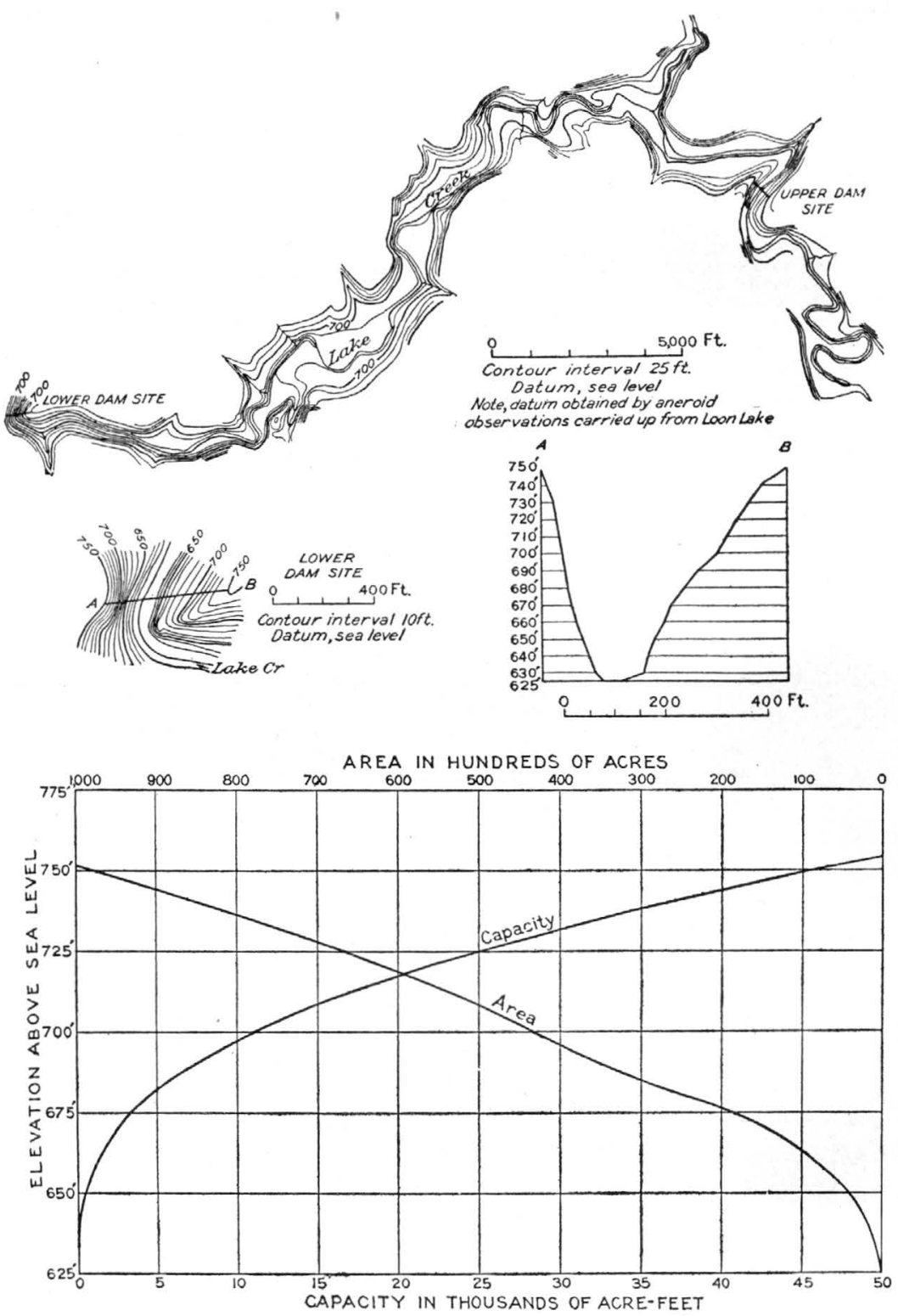

FIgURE 18.-Plan, cross section of lower dam site, and area and capacity curves, Lake Creek reservoir site, Umpqua River Basin

backwater and the increased cost of construction of the dam it would seem inadvisable to develop a reservoir at Loon Lake large enough to control the maximum run-off. A reservoir having a capacity of 100,000 acre-feet would 
have provided a uniform flow throughout four years out of the seven covered by the records. A reservoir of this capacity on the Loon Lake site would have an area of about 2,200 acres. The survey of this reservoir site, made in 1924, was carried only to the 460 -foot contour, at which it would have an area of 1,956 acres, but the mountain slopes at this altitude are steep, and by carrying the dam to the 475-foot contour very little additional area would be flooded. At this altitude the dam would have a length of 1,400 feet. An estimate of 100,000 acre-feet for the reservoir capacity at the 475 -foot contour would not be much in error. Of the total 2,200 acres which would be flooded by this reservoir, approximately 270 acres is included in the natural lake bed at low water. The remainder, or 1,930 acres, comprises land of two grades. The highly cultivated bottom lands, which lie almost wholly within the 440-foot contour, cover about 1,500 acres. The remainder, or 430 acres, would be classed as timbered mountain slopes too steep for agriculture. A fair valuation for the cultivated lands would be $\$ 200$ an acre. The 430 acres of mountain land would be worth perhaps $\$ 50$ an acre. The total valuation of all
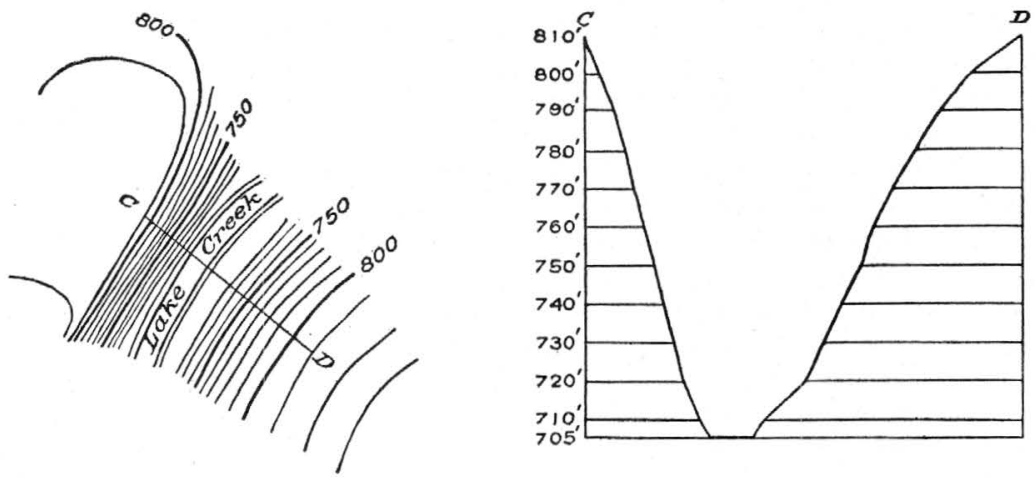

FiguRE 19.--Plan and cross section of upper dam site, Lake Creek reservoir site, Umpqua River Basin

lands that would be flooded by a reservoir of 100,000 acre-feet capacity is roughly $\$ 322,000$. There is no road up the valley of Mill Creek except for about 3 miles at the lower end, and this is impassable owing to landslides. In order to convey material for a dam to the proposed site, 5 or 6 miles of additional road would have to be built.

The alternative storage proposition is the reservoir site near the headwaters of Lake Creek surveyed in 1926 and 1927. Its one outstanding advantage over the Loon Lake site is the comparatively low value of the lands involved, $\$ 50$ an acre being probably a high estimate for this locality. Part of the area is rather marshy and is heavily timbered, except for a small open tract, which is too wet for cultivation unless drained. A dam in sec. 6, T. 24 S., R. 9 W., would collect the run-off from approximately 49 square miles, whereas the Loon Lake site would have a drainage area of 84 square miles. There are two good dam sites on Lake Creek, with sandstone exposed on both banks and in the bed of the stream. (See figs. 18 and 19.) With a dam 125 feet high at the lower of the two sites the storage capacity would be 45,000 acre-feet. Such a dam would be 400 feet long on top, as compared with a dam 1,400 feet long at the mouth of Loon Lake. The foundation conditions at the Lake Creek site are believed to be better than those at Loon Lake, as rock is exposed in both abutments and in the bed of the stream. By adding about 2 feet to the height 
and drawing the head down only within 50 feet of the bottom, 900 continuous horsepower could be generated at this site in a year of low flow; besides partly regulating the flow at Loon Lake and at a proposed site near the mouth of Mill Creek. Daily regulation could easily be provided at Loon Lake by drawing down the lake level, and a combination of the two sites may be the most feasible method of developing the power of the stream. The run-off of the Lake Creek Reservoir site would probably bear the same ratio to the run-off at the Loon Lake site that its drainage basin bears to the basin of the lower site, or 49:84. The maximum annual run-off at the upper site would therefore approximate $239,000 \times \frac{49}{84}$, or 140,000 acre-feet. By regulating the flow at Loon Lake with water stored at the Lake Creek site an equalized flow of 147 to 180 secondfeet could be maintained at Loon Lake. The fall between the Lake Creek site and Loon Lake is not sufficient to justify development of the head between the two sites.

The area of the Lake Creek Reservoir would be about 1,000 acres, and at $\$ 50$ an acre the land would cost $\$ 50,000$, as against $\$ 322,000$ for the Loon Lake site, a difference of $\$ 272,000$, which would possibly be offset by the additional horsepower made available by the Loon Lake site.

There is no road or even a trail up the valley to the Lake Creek Reservoir site, and in order to transport material for the dam a road would have to be built through about 10 miles of dense forest.

A low dam at the outlet of Loon Lake would provide some storage while flooding only a small area beyond that naturally covered at high stages of the lake. Some additional storage could be obtained by tunneling into the lake at an altitude below the present level and drawing the lake down. A reservoir of this kind would be desirable for auxiliary storage in case the Lake Creek Reservoir were built. But the continuous flow from a reservoir of this size as an independent unit would be small, as 6,000 acre-feet would afford an average low-water flow of only 38 second-feet.

The following table gives the minimum flow, by years, at the outlet of Loon Lake which could have been maintained with several storage capacities:

Minimum flow in different years, in second-feet, at outlet of Loon Lake if regulated by storage reservoirs

\begin{tabular}{|c|c|c|c|}
\hline Year & $\begin{array}{l}\text { Loon Lake } \\
\text { Reservoir, } \\
\text { capacity } \\
100,000 \text { acre- } \\
\text { feet }\end{array}$ & $\begin{array}{l}\text { Lake Creek } \\
\text { Reservoir, } \\
\text { capacity } \\
45,000 \text { acre- } \\
\text { feet }\end{array}$ & $\begin{array}{l}\text { Loon Lake } \\
\text { Reservoir } \\
\text { capacity } \\
6,000 \text { acre- } \\
\text { feet }\end{array}$ \\
\hline 1908 & $\begin{array}{l}275 \\
277 \\
283 \\
263 \\
310\end{array}$ & $\begin{array}{l}185 \\
148 \\
147 \\
169 \\
168\end{array}$ & $\begin{array}{l}47 \\
33 \\
36 \\
26 \\
41\end{array}$ \\
\hline Average & 282 & 163 & 38 \\
\hline
\end{tabular}

The advantages of the two methods of development may be summarized as follows :

A reservoir at Loon Lake would produce an increase of about 3,900 horsepower at the Loon Lake site and 800 horsepower at the Mill Creek site, both for 90 per cent of the time, over the power that could be obtained with 45,000 acre-feet of storage in the Lake Creek Reservoir. This increase could be partly offset by about 1,000 horsepower that could be obtained at the Lake Creek Rẹservoir. 
The cost of flowage would be $\$ 272,000$ greater for the Loon Lake site, which would require a dam 1,400 feet long and 80 feet high, as against a dam 400 feet long and 127 feet high at the Lake Creek site. The foundation conditions appear to be much better at the Lake Creek site. The geology at the Loon Lake site is described in connection with the Loon Lake power site (p. 317).

It is possible that the dam at the Lake Creek site could be carried to a height of 150 feet, which would increase the storage capacity by 30,000 -acre-feet, the average low flow by 70 second-feet, and the potential power at low water at Loon Lake by 1,730 horsepower. Such an increase in height would necessitate a dam about 25 feet high and from 1,000 to 1,500 feet long on the ridge that forms the right abutment of the lower Lake Creek site. A dam at the upper Lake Creek site (fig. 19) would create a reservoir with a somewhat larger capacity than one at the lower site for a given height of dam, but the dam would be longer, and the drainage area would be only about twothirds that at the lower site.

\section{KELSAY VALLEY AND TOKETEE FALLS RESERVOIR SITES}

The California-Oregon Power Co. is investigating the possibility of reservoir sites above Toketee Falls and at Kelsay Valley, on the North Umpqua River. At Kelsay Valley a rather long dam will be required, but the water can be used through so much fall at several sites below that the length or cost of the dam will not be the determining factor. There is, however, considerable uncertainty as to the suitability of the foundations for a high dam and also as to the tightness of the reservoir. The whole area of the proposed reservoir is covered with pumice, through which water readily percolates. Beneath the pumice lies a series of lava flows about which little is known except that they fill old stream beds that do not conform to the present drainage system. It is possible that raising the water surface to cover a considerable area of this country would allow the water to find its way through the lava into some of these old courses-for instance, there may be such a channel under Loafer Creek so that any reservoir in this vicinity would be more or less of an experiment, and it is not probable that a high dam would be built without first building a lower structure to test the tightness of the reservoir.

At Toketee Falls the conditions are somewhat different. There seems to be little question of the strength of the foundations at this point to support a dam of any height it is desired to build. Mr. Stearns made an examination of this site on the assumption that a low diversion dam would be built and found that the river at this site has carved a canyon 500 feet deep on basaltic lava. Toketee Falls, about half a mile downstream from the dam site, is formed by the river tumbling over a massive columnar-jointed basalt flow. (See pl. 20, B.)

The basalt at the site and along the proposed canal is permeable, but under the low head of the proposed dam leakage would not be a problem.

A dam at Toketee Falls to raise the water surface 200 feet above the present level, to an altitude of 2,550 feet, would furnish 46,000 acre-feet of storage with 100 feet drawdown. This water could be used through a gross head of 2,540 feet at proposed plants, and at an efficiency of 70 per cent it would furnish 4,720,000 horsepower-days, or $84,000,000$ kilowatt-hours of power. The loss of power due to loss of head would amount to only a small percentage of this total. If spread evenly over a period of five months this water would add about 31,000 horsepower to the power of the system during the period of low water.

A dam below Poole Creek to raise the water surface to an altitude of 4,200 feet would furnish about 65,000 acre-feet of storage, which with complete 
development of the river could be used through a gross head of 4,190 feet. With this head and an efficiency of 70 per cent a total of $11,000,000$ horsepowerdays, or 197,000,000 kilowatt-hours, could be generated. If spread evenly over a period of five months this would add 72,000 horsepower to the potential power during the period of low water.

It is possible that suitable dam sites will be found for these two reservoirs and that the leakage will not be great. If so, they may add as much as $\mathbf{1 0 0 , 0 0 0}$ horsepower to the potential power of the North Umpqua River during low stages. The increased flow will also make all the sites on the river more desirable. On the other hand, the geologic conditions render the feasibility of high dams at these points doubtful, and they have not been included in estimates of the potential power of the Umpqua River Basin.

\section{WATER POWER}

The rainfall over the drainage basin of the North Umpqua River above the mouth of Copeland Creek is 75 to 100 inches annually, insuring a plentiful supply of water in years of average rainfall. This area also has a porous volcanic-ash soil which gives a large ground storage of water and a well-sustained flow from the mouth of Lake Creek, where the altitude is 4,100 feet, to sea level. The North Umpqua and Umpqua Rivers throughout their courses flow in canyons and afford numerous good dam sites. All these conditions combine to make the North Umpqua and Umpqua ideal streams for water power.

The Clearwater River, a tributary of the North Umpqua River, has a well-sustained headwater flow and a very steep gradient, and it also is valuable for power.

Loon Lake, on Mill Creek, a tributary of the Umpqua River, is a natural reservoir site, and although the fall is not great, several thousand horsepower can be obtained on this creek.

The remaining tributaries of the Umpqua River, including the South Umpqua River, have periods of low flow during the summer owing to low rainfall and a lack of ground storage. Some power can be obtained on the South Umpqua by the construction of reservoirs, but it will be expensive, and the time of development is remote.

\section{DEVELOPED POWER}

In 1928 only one hydroelectric plant was in operation in the Umpqua River Basin, but active investigations were being carried on at several proposed sites. A plant of 163 horsepower capacity on the South Umpqua River at Roseburg was dismantled about 1921. A plant of about 66 horsepower at Myrtle Creek was also dismantled about the same time. In both places power from the plants of the California-Oregon Power Co. took the place of the less efficient and less reliable small plants. 
At the town of Winchester, north of Roseburg, in the NE. $1 / 4$ sec. 25, T. 26 S., R. 6 W., on the North Umpqua River, a long wood dam creates a head of about 12 feet. The installation consists of three water wheels, with a rated capacity of 1,900 horsepower, and three generators, rated at 1,250 kilovoltamperes. There is an auxiliary steam engine with a capacity of 350 horsepower. As the potential power of the site with 12 feet head and the fiow available for 50 per cent of the time is only 2,320 horsepower, the capacity of the plant can not be economically increased without raising the height of the dam, which does not appear to be feasible, as the left bank of the river is low at this point. However, this is a cheap development, near the market of Roseburg, and can probably be operated to advantage indefinitely. In considering the potential power of the river this site has been combined with the site about $1 \frac{1}{2}$ miles upstream, for if the upper site is utilized this lower plant will be operated automatically from the upper plant, or the head will have to be developed by a canal, and the dam at this point will then be discarded.

Summary of potential power at developed site 12RB 17

[Head, 12 feet]

\begin{tabular}{|c|c|c|c|c|}
\hline & \multicolumn{2}{|c|}{ Flow in second-feet } & \multicolumn{2}{|c|}{ Horsepower } \\
\hline & $\begin{array}{l}90 \text { per } \\
\text { cent of } \\
\text { time }\end{array}$ & $\begin{array}{l}50 \text { per } \\
\text { cent of } \\
\text { time }\end{array}$ & $\begin{array}{l}90 \text { per } \\
\text { cent of } \\
\text { time }\end{array}$ & $\begin{array}{l}50 \text { per } \\
\text { cent of } \\
\text { time }\end{array}$ \\
\hline $\begin{array}{l}\text { Natural flow } \\
\text { Regulated flow } \\
\text { Regulated flow, } 1926 \text {. }\end{array}$ & $\begin{array}{r}960 \\
1,520 \\
1,250\end{array}$ & $\begin{array}{l}2,420 \\
2,570 \\
1,950\end{array}$ & $\begin{array}{r}922 \\
1,460 \\
1,200\end{array}$ & $\begin{array}{l}2,320 \\
2,470 \\
1,870\end{array}$ \\
\hline
\end{tabular}

\section{UNDEVELOPED POWER}

In outlining power projects and methods of operation in this report the object has been to set forth the maximum amount of power obtainable. In some places the head could be developed more cheaply by a conduit than by a high dam, but the dam would create a certain amount of storage, and although the use of the stored water at the single site inight not justify the added cost, yet, if all the sites below were utilized, the stored water would be worth considerably more than the difference in cost. The net gain in power due to drawing down the head at dams built primarily for power would amount to 108,000,000 kilowatt-hours. (See Table 10.)

As no estimates of stream flow for the upper basin are available for years before 1925, the power that could be obtained with storage was studied on the basis of the flow for the two years 1925 and 1926. The mean flow in 1925 was high, but the discharge for the summer was about normal, and that for the fall and early winter was low. The stream flow in 1926 was as low as any other of record. These two years therefore give a fair idea of what could be accomplished with storage. The estimates of power available with regulated flow 
are based on the discharge for 1925 and are followed by estimates based on the discharge for 1926 to show what can be obtained in a year of very low flow.

On the Umpqua River the discharge at the different dam sites can not be estimated by means of comparing drainage areas, because a large part of the flow comes from springs. Gaging stations have been maintained at Winchester, at Oak Creek, above Rock Creek, and below the Clearwater River, and some miscellaneous measurements have been made above the mouth of Lake Creek. From these sources the Q90 and Q50 flows at the dam sites have been estimated without much reference to comparative drainage areas, by using the roughly estimated inflow at low water from the tributary streams.

In determining the power available on the North Umpqua and Umpqua Rivers for 90 per cent of the time and 50 per cent of the time with storage, it was assumed that all the plants would be operated as one system. The object was to obtain a maximum continuous output from the system, and it was assumed that the upper reservoirs would be drawn down at a uniform rate over a period of four months from August to November. This rate applied to the Diamond Lake, Soda Springs, Copeland, and Steamboat sites. The storage in the Boundary Reservoir would be so large that it was spread over five months, from July to November. At the Clark ranch the stored water was assumed to be used in September, October, and November. At sites below the Clark ranch it was desired to maintain the head as late in the season as the conditions of flow and power output would permit, and at Glide, Horseshoe Bend, Winchester, and Oak Creek the stored water was assumed to be used in October and November. The Coles Valley or Wolf Creek Reservoir would be used to equalize the power output of the system, and the stored water would have been used during the periods from July to November, 1925, and June to November, 1926. Not all the stored water would have been used in 1926, as a heavy rain raised the river on November 12. But as this rise could not be foreseen, it was assumed that the storage would have been used so as to augment the flow if necessary throughout November. It was assumed that the storage belcw Wolf Creek would be used only in case of low water lasting into the late fall or early winter and therefore that the stored water at the Kellogg and Kelley's Smith Ferry sites would have been used in December, 1925, and part of it in November, 1926. The stored water at Scottsburg was assumed to be used in December, 1925 , and none of it in 1926 . In a large system with steam auxiliary it would be possible to use the stored water more efficiently, as no reserve for emergency would be necessary. 


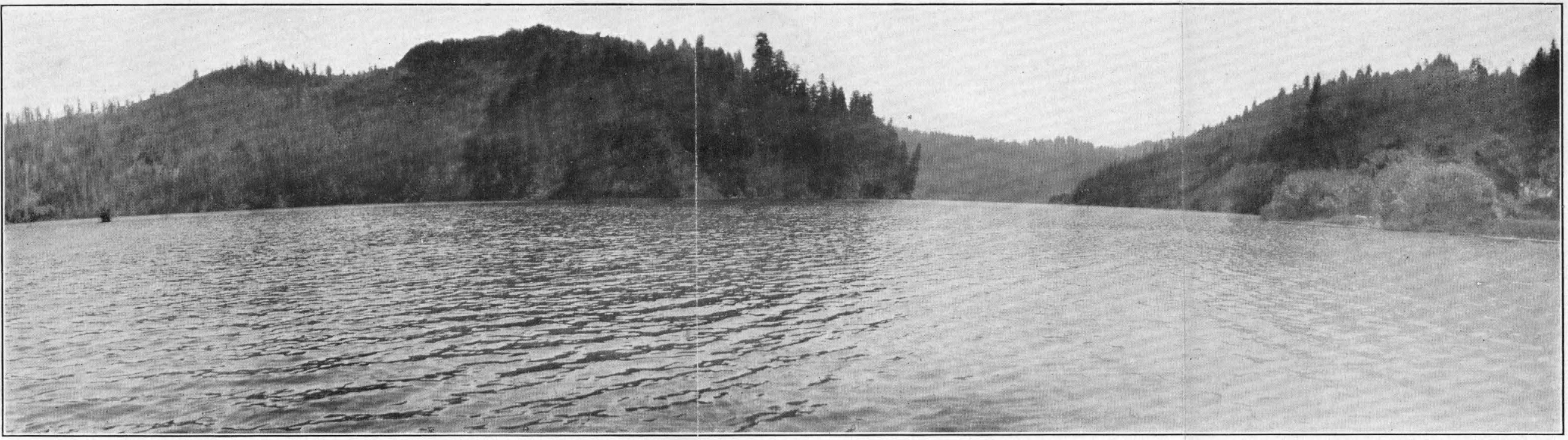

A. LOON LAKE, UMPQUA RIVER BASIN

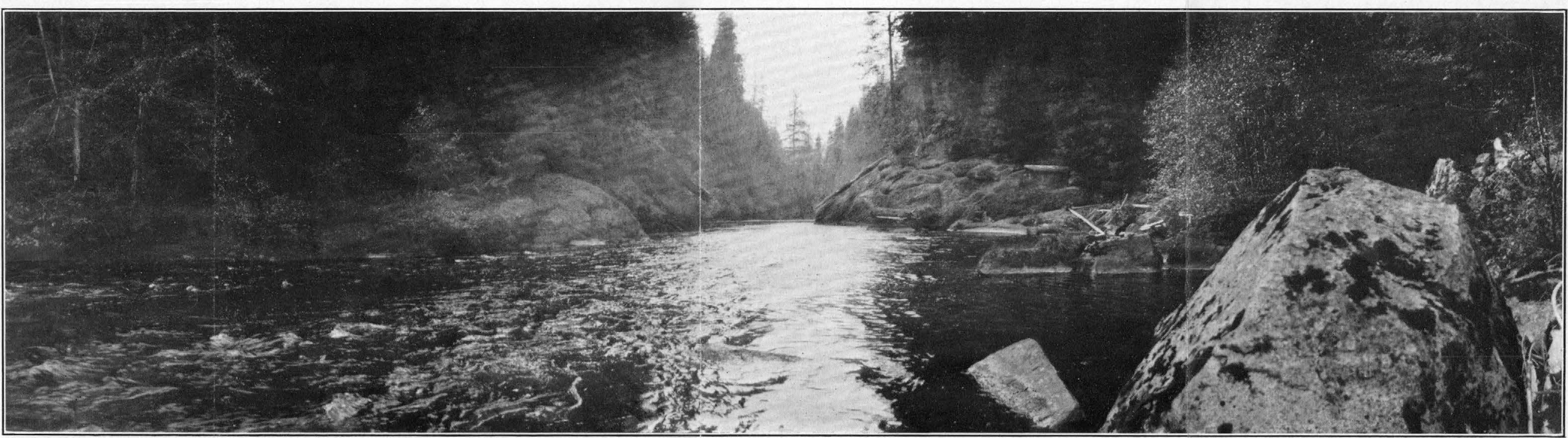

B. SODA SPRINGS DAM SITE, UMPQUA RIVER BASIN

Looking downstream. 


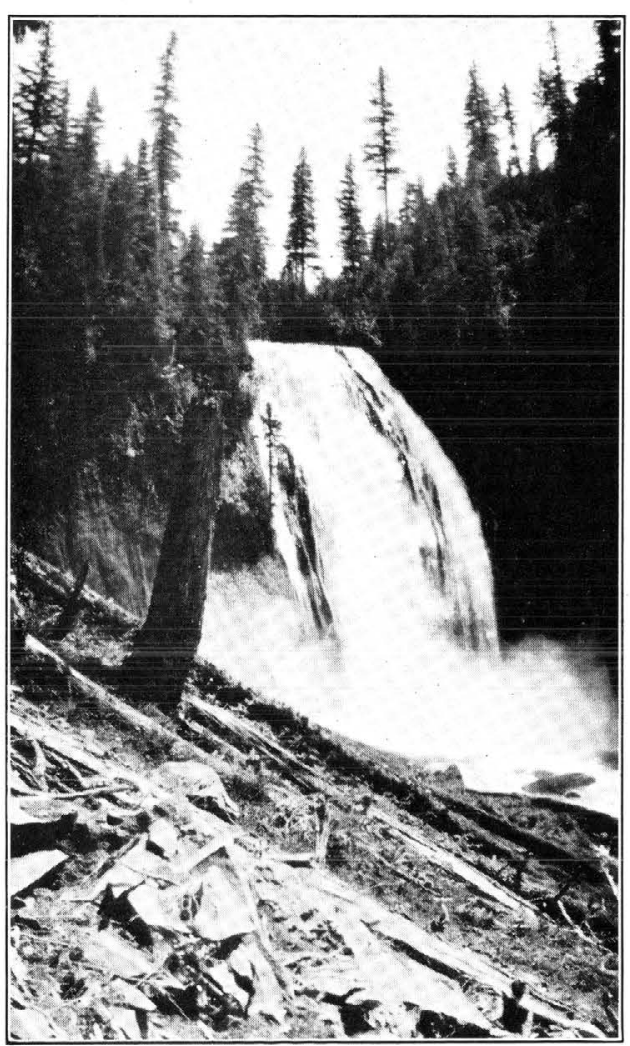

A. LEMOLO FALLS, UMPQUA RIVER BASIN

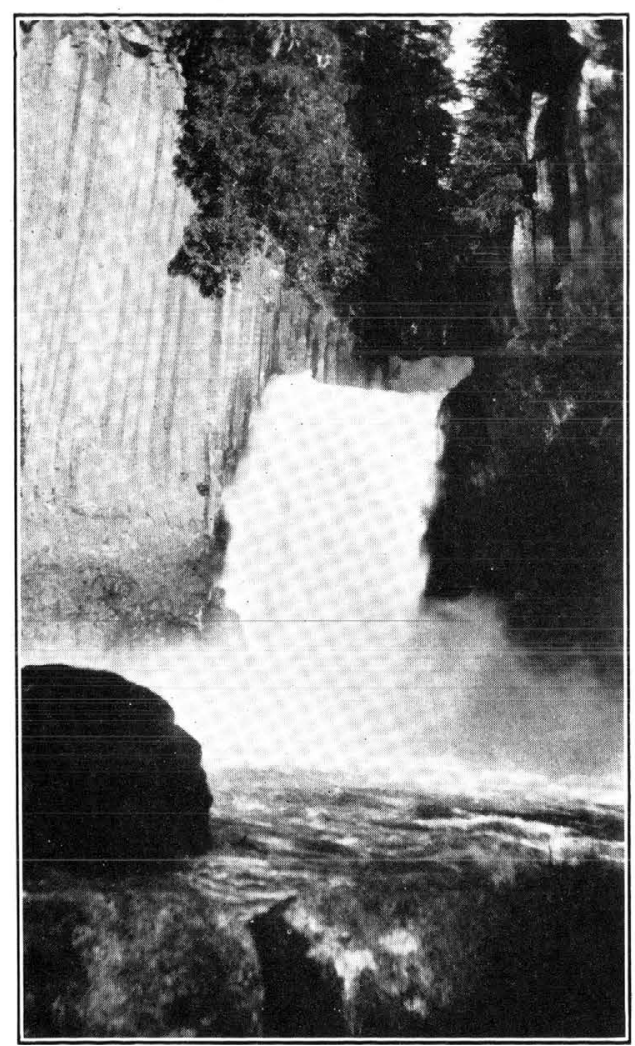

B. TOKETEE FALLS, UMPQUA RIVER BASIN 
In estimating the power available with storage for 90 per cent of the time the amount for the second lowest month was used, and for 50 per cent of the time the amount for the sixth highest month. At many sites the summary tables show a regulated Q50 flow that is larger than the corresponding natural flow, and yet the power available with the natural flow may be as large as the power with regulated flow or even larger. This condition is due to drawing down the head at the dam for storage purposes. At other sites the regulated Q50 flow is less than the corresponding natural flow, and this condition is of course due to storage.

\section{NORTH UMPQUA AND UMPQUA RIVERS}

\section{KELSAY POWER SITE (12RB 1)}

The proposed scheme of development for the Kelsay power site would consist of a low diversion dam just below the mouth of Lake Creek and a conduit 3 miles long to a point half a mile above Lemolo Falls. The total head would amount to 300 feet. The flow could be augmented by water stored in Diamond Lake. The construction of the conduit would not be difficult; but it might have to be lined, as a large part of this country is covered with volcanic ash. A new highway called the Skyline Trail passes near the mouth of Lake Creek, but a logging railroad will probably be built into the basin and would furnish the cheapest transportation. The estimates of power available at this site with storage are based on the assumption that 30,000 acre-feet of water can be stored in Diamond Lake and used to equalize the summer flow at Toketee Falls.

The California-Oregon Power Co. is investigating the possibility of developing this site by means of a high dam below Poole Creek. This project is discussed on page 259. It is also proposed to tunnel through the ridge in the neighborhood of Basket Butte and construct a canal down the south side of the Loafer Creek Basin to intersect the North Umpqua River at Umpqua Warm Springs. Aside from the tunnel through Basket Butte, this project would be very economical, considering the head obtained. Basket Butte is apparently a cinder cone, and the tunnel might encounter cinders, lava, and possibly mud, but there appears to be no good reason why the tunnel can not be built. Such a project would develop the head included in power sites 12RB 1, 2, 3, and 4 in this report.

Potential power at undeveloped site 12RB 1

[Hesd, 300 feet]

\begin{tabular}{|c|c|c|c|c|}
\hline & \multicolumn{2}{|c|}{ Flow in second-feet } & \multicolumn{2}{|c|}{ Horsepower } \\
\hline & $\begin{array}{l}90 \text { per } \\
\text { cent of } \\
\text { time }\end{array}$ & $\begin{array}{l}50 \text { per } \\
\text { cent of } \\
\text { time }\end{array}$ & $\begin{array}{l}90 \text { per } \\
\text { cent of } \\
\text { time }\end{array}$ & $\begin{array}{l}50 \text { per } \\
\text { cent of } \\
\text { time }\end{array}$ \\
\hline $\begin{array}{l}\text { Natural flow } \\
\text { Regulated flow } \\
\text { Regulated flow, } 1926.0\end{array}$ & $\begin{array}{l}300 \\
275 \\
265\end{array}$ & $\begin{array}{l}450 \\
440 \\
350\end{array}$ & $\begin{array}{l}7,200 \\
6,600 \\
6,360\end{array}$ & $\begin{array}{r}10,800 \\
10,600 \\
8,400\end{array}$ \\
\hline
\end{tabular}


IEMOLO FALLS POWER SITE (12RB 2)

A low diversion dam is proposed at a place about half a mile above Lemolo Falls (see pl. 20, $A$ ), with a tunnel 4 miles long to mile 167, below the mouth of Potter Creek. A head of 750 feet would be obtained, or nearly 200 feet to the mile. The tunnel would be in lava rock and probably would require lining. It would be necessary to build about 12 miles of highway to the power-house site, but only about 2 miles would be difficult of construction, as there is a good location from the Skyline Trail down Loafer Oreek to Thorn Prairie. From Thorn Prairie the road would run up the North Umpqua along the side of Dread and Terror Ridge, and this section would be more expensive to grade. Even this section, however, would involve very little rock work. There are many springs along the river between Lake Creek and Lemolo Falls, and the low-water flow would be appreciably greater than at the mouth of Lake Creek. The only regulation considered in estimating the power at this site is that in Diamond Lake, and the estimates of flow and power available with storage at this site are based on the use of that storage to regulate the flow at Toketee Falls.

Potential power at undeveloped site 12RB 2

[Head, 750 feet]

\begin{tabular}{|c|c|c|c|c|}
\hline & \multicolumn{2}{|c|}{ Flow in second-feet } & \multicolumn{2}{|c|}{ Horsepower } \\
\hline & $\begin{array}{l}90 \text { per } \\
\text { cent of } \\
\text { time }\end{array}$ & $\begin{array}{l}50 \text { per } \\
\text { cent. of } \\
\text { time }\end{array}$ & $\begin{array}{l}90 \text { per } \\
\text { cent of } \\
\text { time }\end{array}$ & $\begin{array}{l}50 \text { per } \\
\text { cent of } \\
\text { time }\end{array}$ \\
\hline $\begin{array}{l}\text { Natural flow } \\
\text { Regulated flow, } \\
\text { Regulated flow, } 1926 \text {. }\end{array}$ & $\begin{array}{l}320 \\
295 \\
280\end{array}$ & $\begin{array}{l}500 \\
460 \\
387\end{array}$ & $\begin{array}{l}19,200 \\
17,700 \\
16,800\end{array}$ & $\begin{array}{l}30,000 \\
27,600 \\
23,200\end{array}$ \\
\hline
\end{tabular}

Lemolo Falls possess some scenic beauty, but it would seem poor judgment to neglect to use the power available at this site solely on that account. Scenery is plentiful in this section, with its mountains, forests, and many small streams that are beautiful without waste, whereas more than 17,000 continuous horsepower can be generated at this site and is being wasted.

\section{POTTER CREEK POWER SITE' (12RB 3)}

A low diversion dam is proposed just below the power house at site 12RB 2, below Potter Creek, with a conduit 3 miles long to mile 164, where the Kelsay Valley Trail crosses the river. A head of 250 feet can be obtained in this distance. It would be necessary to build about 10 miles of highway to this site, but there would be little difficult grading, as it would follow the old Bradley or Kelsay Valley Trail. The conduit could be located on either bank, but below Dread and Terror Ridge the left bank is more open. The estimated regulated discharge at this site is based on the estimated discharge in 1925, which is assumed as an average year during the low-water season, and in 1926, a year of minimum flow. It is possible that the regulated discharge in 1926 would have been even lower than is estimated, as no records are available of the run-off at the mouth of Diamond Lake, and this estimate assumes that 30,000 acre-feet of water could have been stored in that lake. 
Potential power at undeveloped site 12RB 3

[Head, 250 feet]

\begin{tabular}{|c|c|c|c|c|}
\hline \multirow{2}{*}{ 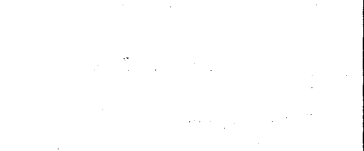 } & \multicolumn{2}{|c|}{ Flow in second-feet } & \multicolumn{2}{|c|}{ Horsepower } \\
\hline & $\begin{array}{l}90 \text { per } \\
\text { cent of } \\
\text { time }\end{array}$ & $\begin{array}{l}50 \text { per } \\
\text { cent of } \\
\text { time }\end{array}$ & $\begin{array}{l}90 \text { per } \\
\text { cent of } \\
\text { time }\end{array}$ & $\begin{array}{l}50 \text { per } \\
\text { cent of } \\
\text { time }\end{array}$ \\
\hline $\begin{array}{l}\text { Natural flow } \\
\text { Regulated flow } \\
\text { Regulated flow, } 1926\end{array}$ & $\begin{array}{l}360 \\
360 \\
340\end{array}$ & $\begin{array}{l}550 \\
515 \\
412\end{array}$ & $\begin{array}{l}7,200 \\
7,200 \\
6,800\end{array}$ & $\begin{array}{r}11,000 \\
10,300 \\
8,240\end{array}$ \\
\hline
\end{tabular}

IOAFER CREEK POWER SITE (12RB 4)

A low diversion dam is proposed at mile 164, just below power-house site 12RB 3, with a conduit to a point below Loafer Creek, a distance of $2 \frac{1}{2}$ miles. The fall in this distance is 200 feet. The conduit would probably follow the right bank, and it could best be reached by building a road along the old Bradley Trail. There would be no difficult construction in this project. The conduit could be either a lined open canal or a pipe line. The estimated regulated flow given in the table below is based on the discharge in 1925, an average year during the low-water season, and in 1926, a year of minimum flow. It was assumed that 30,000 acre-feet of water was stored in Diamond Lake each year and used to equalize the flow at Toketee Falls.

Potential power at undeveloped site 12RB 4

[Head, 200 feet]

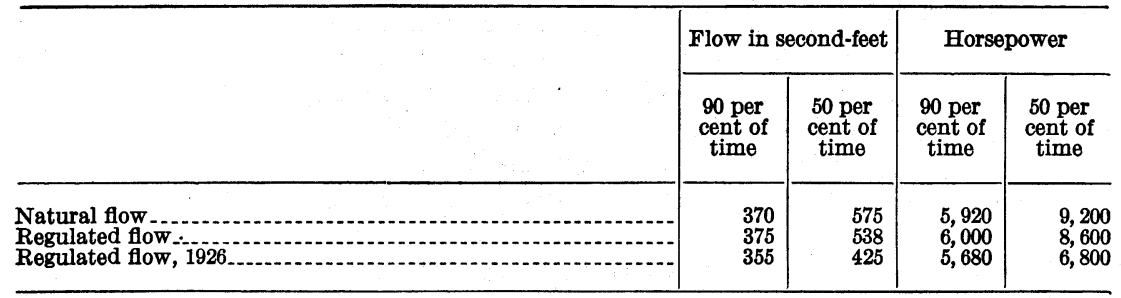

BRIDGE POWER SITE (12RB б)

Water for the proposed Bridge plant would be diverted just below the power house of site 12RB 4, near Umpqua Warm Springs, and carried by conduit to a point near the mouth of the Clearwater River, a distance of $4 \frac{1}{2}$ miles. The total fall in this distance is 220 feet. The conduit would probably follow the right bank and would cross Deer Creek. This site is rather difficult of access, but if a road were built to either the Toketee Falls site below or the Loafer Creek site above, it would be a simple matter to extend the road along this stretch of the river. Here, as at other sites, the estimated flow and power available with storage are based on records for 1925, a year of average discharge during the low-water months, and 1926, a year of minimum flow. The storage in Diamond Lake was assumed to equalize the flow at Toketee Falls for the period August to November. December, 1925, was a month of low flow on the upper river, but there was plenty of water at sites on the lower 
river and probably at other points in the State, so that the power market could have been supplied from other water-power plants. As these plants on the upper river probably would be a part of a large system it is assumed that the storage would be used to best advantage in the four months mentioned.

Potential power at undeveloped site 12RB 5

[Head, 220 feet]

\begin{tabular}{|c|c|c|c|c|}
\hline & \multicolumn{2}{|c|}{ Flow in second-feet } & \multicolumn{2}{|c|}{ Horsepower } \\
\hline & $\begin{array}{l}90 \text { per } \\
\text { cent of } \\
\text { time }\end{array}$ & $\begin{array}{l}50 \text { per } \\
\text { cent of } \\
\text { time }\end{array}$ & $\begin{array}{l}90 \text { per } \\
\text { cent of } \\
\text { time }\end{array}$ & $\begin{array}{l}50 \text { per } \\
\text { cent of } \\
\text { time }\end{array}$ \\
\hline $\begin{array}{l}\text { Natural flow } \\
\text { Regulated flow } \\
\text { Regulated flow, } 1926\end{array}$ & $\begin{array}{l}460 \\
500 \\
450\end{array}$ & $\begin{array}{l}700 \\
638 \\
501\end{array}$ & $\begin{array}{l}8,100 \\
8,800 \\
7,920\end{array}$ & $\begin{array}{r}12,300 \\
11,200 \\
8,820\end{array}$ \\
\hline
\end{tabular}

TOKETEE FAILS POWER SITE (12RB 6)

A diversion dam not more than 25 feet high is proposed for the Toketee Falls site, to be located below the mouth of the Clearwater River. The conduit will probably follow the left bank to a point about half a mile below the falls, a distance of less than a mile. The head would be 260 feet.

The river at this site has carved a canyon 500 feet deep in basaltic lava. Toketee Falls, about half a mile downstream from the dam site, is formed by the river tumbling over a massive columnar-jointed basalt flow. (See pl. 20, B.) The basalt at the site and along the proposed canal line is permeable, but under the low head of the proposed dam the leakage would probably not exceed 5 or 10 second-feet. The canal can be protected from losses by lining it. Storage of 30,000 acre-feet in Diamond Lake has been assumed to be used to equalize the flow at this site. Estimates of regulated flow and potential power are given for an average year and for 1926, a year of minimum flow. The deep canyon renders this site somewhat difficult of access, but there is already a road practically to the edge of the canyon, and materials could be lowered to the river.

Records are available at this site for 1925 and 1926, and the discharge for these two years was 560 second-feet for 90 per cent of the time and 789 secondfeet for 50 per cent of the time. In 1925 the corresponding discharges were 675 and 1,000 second-feet. The natural flow as given in the following table is estimated from these records for 1925 :

Potential pouer at undeveloped site 12RB 6

[Head, 260 feet]

\begin{tabular}{|c|c|c|c|c|}
\hline & \multicolumn{2}{|c|}{ Flow in second-feet } & \multicolumn{2}{|c|}{ Horsepower } \\
\hline . & $\begin{array}{l}90 \text { per } \\
\text { cent of } \\
\text { time }\end{array}$ & $\begin{array}{l}50 \text { per } \\
\text { cent of } \\
\text { time }\end{array}$ & $\begin{array}{l}90 \text { per } \\
\text { cent of } \\
\text { time }\end{array}$ & $\begin{array}{l}50 \text { per } \\
\text { cent of } \\
\text { time }\end{array}$ \\
\hline $\begin{array}{l}\text { Natural flow } \\
\text { Regulated flow } \\
\text { Regulated flow, } 1926.0\end{array}$ & $\begin{array}{l}650 \\
724 \\
639\end{array}$ & $\begin{array}{r}1,000 \\
875 \\
677\end{array}$ & $\begin{array}{l}13,500 \\
15,100 \\
13,300\end{array}$ & $\begin{array}{l}20,800 \\
18,200 \\
14,100\end{array}$ \\
\hline
\end{tabular}


The fall per mile is not great above the mouth of the Clearwater River, the valley is about a quarter of a mile wide, and in some ways this would make an excellent reservoir site with a high dam above Toketee Falls. The dam site, however, is not attractive. The dam would be about 1,000 feet long on top and its abutments would be composed of a series of lava flows, so that the reservoir would undoubtedly leak, but how much it is difficult to say without detailed studies. With a dam 200 feet high 46,000 acre-feet of storage could be obtained in the upper 100 feet. The high dam would take the place of the low diversion dam at Toketee Falls and 4 miles of conduit. The high dam may not be feasible for present development, but the Bridge site above will be one of the last sites developed on the upper river. If all the sites are developed below it may then prove advantageous to develop this stretch of river by rebuilding the dam at Toketee Falls for storage and power. The storage obtained could be used through a total gross head of 2,540 feet and would generate a maximum of $84,000,000$ kilowatt-hours. Such an amount of power during the low-water period certainly warrants a complete investigation of the site before it is rejected.

\section{BRADLEY POWER SITE (12RB 7)}

Water would be diverted for the Bradley power project at a point just below the Toketee Falls power house and carried by conduit downstream to about mile 154.6, a distance of $1 \frac{1}{2}$ miles. The head obtained in this distance amounts to $\mathbf{1 8 0}$ feet. The limits of this project are not definitely fixed, and much depends on the extent to which sites downstream are developed. An additional 100 feet of head could be obtained by extending the conduit another mile downstream. But this head could also be developed by building a high dam at Soda Springs, which would afford considerable storage capacity. By drawing down the water surface above the Soda Springs dam 80 feet, if all proposed sites below were constructed, about $13,000,000$ kilowatt-hours net increase in power could be obtained from stored water, and in addition the cost of a mile of conduit along a steep hillside or a mile of pressure pipe would be saved." On the other side of the ledger is the increased cost of a dam 200 feet high at Soda Springs, as compared with one 100 feet high. If built at the present time, when there is little power development below, the longer conduit at this site would be much better than a high dam at Soda Springs. But it is believed that all the sites on the river are feasible and that most of them will be completed before the Soda Springs site is utilized. Under these circumstances, a high dam at Soda Springs would probably be the most feasible plan because of the storage available, and estimates of power available with storage are based on that assumption. With either height of dam at Soda Springs the power house of the Bradley site would be above Fish Creek. The river in this section flows in a narrow gorge, and construction of a conduit would be difficult. A tunnel a little over a mile long would develop 180 feet of head, as proposed for this unit, and would probably be the cheapest construction. It would be driven through lava flows, where water might be encountered. and would require lining The regulated flow at this site assumes 30,000 acre-feet of storage available in Diamond Lake and its use to equalize the flow at Toketee Falls.

$$
47154^{\circ}-30-18
$$


Potential power at undeveloped site 12RB $\mathrm{Y}$

[Head, 180 feet]

\begin{tabular}{|c|c|c|c|c|}
\hline & \multicolumn{2}{|c|}{ Flow in second-feet } & \multicolumn{2}{|c|}{ Horsepower } \\
\hline & $\begin{array}{l}90 \text { per } \\
\text { cent of } \\
\text { time }\end{array}$ & $\begin{array}{l}50 \text { per } \\
\text { cent of } \\
\text { time }\end{array}$ & $\begin{array}{l}90 \text { per } \\
\text { cent of } \\
\text { time }\end{array}$ & $\begin{array}{l}50 \text { per } \\
\text { cent of } \\
\text { time }\end{array}$ \\
\hline $\begin{array}{l}\text { Natural flow ...... } \\
\text { Regulated flow } \\
\text { Regulated flow, } 1926 \text {. }\end{array}$ & $\begin{array}{l}700 \\
750 \\
655\end{array}$ & $\begin{array}{r}1,100 \\
925 \\
750\end{array}$ & $\begin{array}{r}10,100 \\
10,800 \\
9,430\end{array}$ & $\begin{array}{l}15,800 \\
13,300 \\
10,800\end{array}$ \\
\hline
\end{tabular}
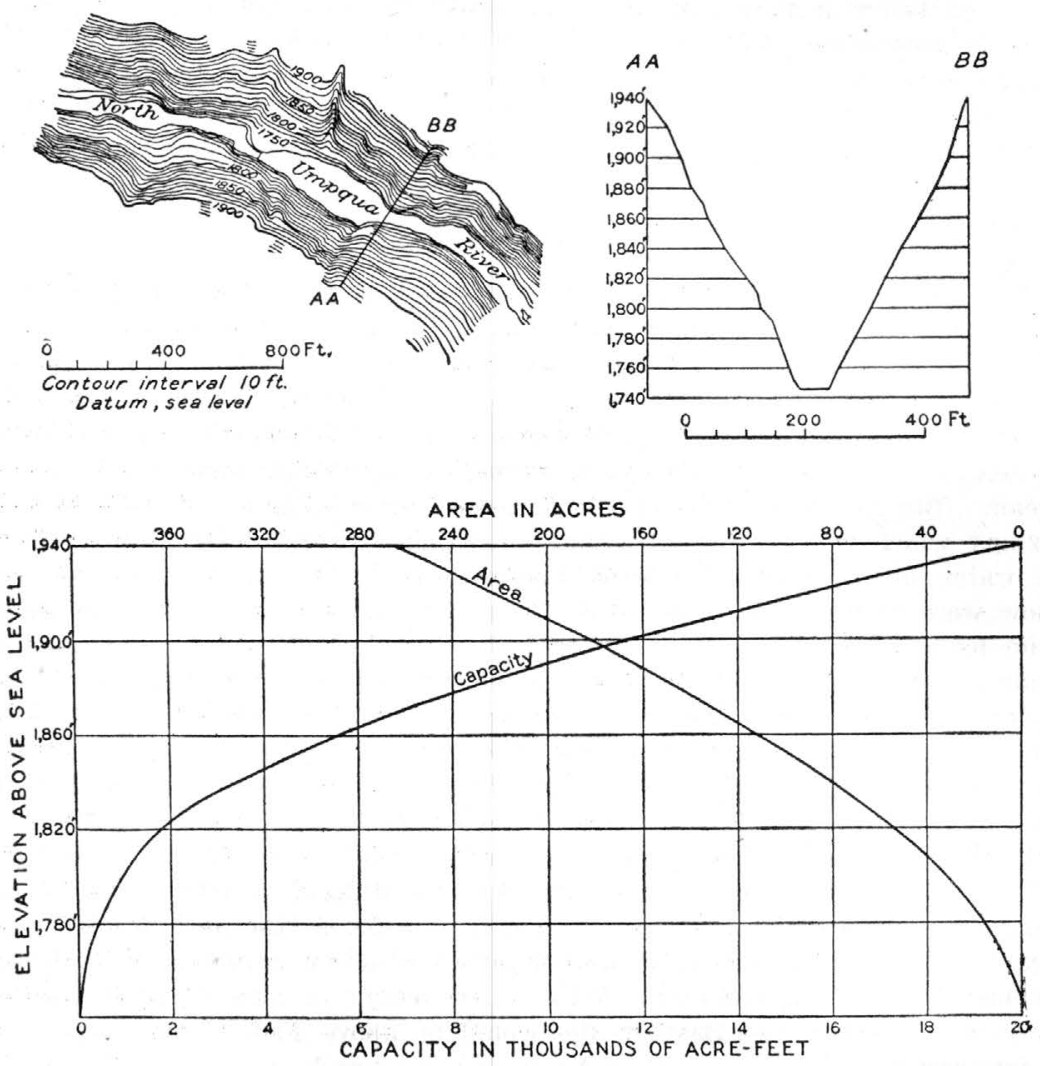

FIGURE 20.-Plan, cross section, and area and capacity curves, Soda Springs dam site, Umpqua River Basin

\section{SODA SPRINGS POWER SITE (12RB 8)}

A dam 200 feet high is tentatively proposed for the Soda Springs site, which is at mile 151.7, half a mile above Soda Springs. Such a dam would raise the water surface to an altitude of 1,940 feet above sea level and would flood 265 acres. (See pl. 19, B, and figs. 20 and 21.) A high dam is preferred because it would provide storage and because under certain conditions it would be financially the best method of development. The upper 100 feet of head could be developed by extending the canal from the Bradley power site, a mile farther 
downstream, and if only a small part of the head below this site was developed the canal would be the best arrangement. But if all the sites below were developed the storage at this site, with a dam 200 feet high and a drawdown of 80 feet, would yield $13,000,000$ kilowatt-hours net gain in power in a normal year. A dam 200 feet high would require 155,000 cubic yards of masonry, whereas a dam 100 feet high would require 35,000 cubic yards, a difference in favor of the lower dam of 120,000 cubic yards. Against this should be balanced the cost of a mile of canal and about $13,000,000$ kilowatt-hours of power available in the low-water months. If this site is considered alone it would not pay to draw down the head for storage, as the loss of head over a period of two months would probably more than offset the power obtained from the stored water. It is only because of the large number of possible sites below that a drawdown for storage would be feasible at this site. Below the dam a tunnel about a mile in length would add 75 feet to the head. The total head at this site would then be 275 feet, and the average head, with 80 feet of drawdown; would be 240 feet.

There is some question as to the value of this dam site with respect to geo logic conditions. If detailed examinations and drillings show the site to be unfavorable the power could be developed by a conduit, and the only loss in power would be that which could be obtained from storage.

The Soda Springs dam site is in a V-shaped canyon. The north wall of the canyon is 2,500 feet high, but the south wall rises abruptly for 1,000 feet to a flat-topped bench, half a mile wide, and thence rises another 500 feet to the south rim of the canyon. The north abutment is composed of massive volcanic agglomerate, consisting of lava fragments cemented in a fine ash and undoubtedly of explosive origin. No fossils were found in it, but it may possibly be of submarine origin, produced by a submarine eruption. It has a thin soil cover, but near the river it is well exposed. Regardless of the origin of the agglomerate it is massive, sparsely jointed, and admirably adapted for the abutment of a dam. On the south bank the same massive green agglomerate crops out for a distance of about 25 feet above the river. Above this the slope is thickly forested, and time was not available during the trip to examine the south abutment because of its inaccessibility. However, the bench on the south side of the river is known to be formed of a series of intracanyon basalt flows, which entered the upper stretches of the North Umpqua and flowed down it for many miles. At this site there is evidence that the lava fill is 1,000 feet thick. After the canyon was filled to this depth by lava flows, volcanic activity ceased at its headwaters, and the river returned to its partly filled canyon. It began cutting with renewed vigor at the lowest place in the new valley floor. In some parts of its canyon this place was at the contact of the lava with the canyon wall. Continued erosion at the contact excavated a canyon partly in the lava and partly in the agglomerate of the canyon wall. At such places the river did not work down into its buried channel but on one side or the other of it. This is what happened at the Soda Springs dam site, for the river is now eroding agglomerate, leaving the buried channel about one-eighth to one-fourth of a mile south of the present one. A geologic cross section. representing the conditions at the site is shown in Figure 21.

On the south bank about 500 feet upstream from the site columnar basalt extends below the water surface of the river. It is the outcrop of a dense basalt flow, at least $\mathbf{7 5}$ feet thick. About the same distance downstream from the site the same basalt again extends below the water surface along the south bank. Because the ancient channel is not exposed at these places it is concluded that the Umpqua River,..where it is cutting close to the axis of its 
former valley, has not yet excavated the present channel to the depth of its ancient one. The present valley therefore lies above the buried one. The difference in their altitudes is only approximately shown in Figure 21, and drilling will be necessary to determine the actual location of the buried channel.

The intracanyon basalt remnants form benches downstream from the site, which are known as Oak Flat, Burnt Flat, Pine Bench, and Illihe. Wherever possible, the outcrops in these benches were examined to determine the structure of the lava beds. In general the intracanyon flows are thin bedded, jointed, and cavernous and are without doubt extremely permeable. Fortunately the lower member of the intracanyon basalt is a bed about 75 feet thick with relatively tight joints.

The value of the Soda Springs dam site is imperiled by the presence of the buried ancient channel of the Umpqua, which has its intake upstream from the site and lies about one-eighth of a mile south of the abutment of the proposed dam, and also by leaky structures existing in the intracanyon flows. The chance of considerable leakage through the intracanyon basalt is greatly re. duced, however, by the presence at the base of the lava flows of a bed of basalt with a thickness nearly equal to the depth of the reservoir that would be formed by the proposed dam. The site is well worth further geologic study, supplemented by drilling to determine the character of the buried channel and

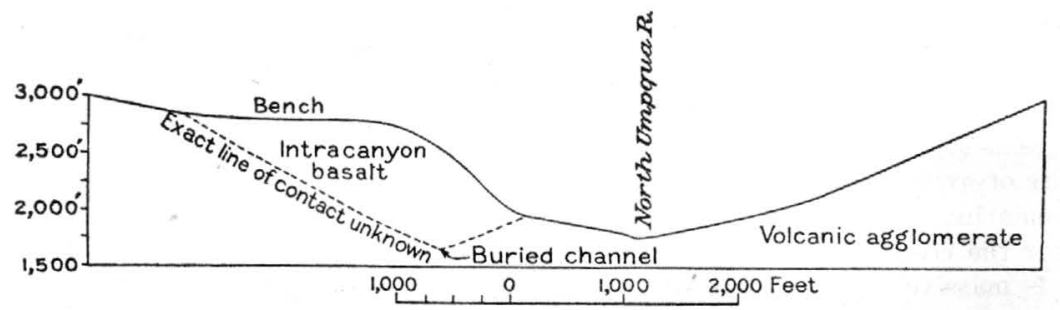

Figure 21.-Geologic section at Soda Springs dam site, Umpqua River Basin

its permeability, as well as of the basalt overlying it. A power dam at this point could stand considerable seepage losses without failure.

The natural flow at this site was estimated from duration curves for gaging stations above Rock Creek and at Toketee Falls. The estimate for regulated flow assumes 30,000 acre-feet of storage available in Diamond Lake and used to regulate the flow at Toketee Falls. The flow at this site is assumed to be again regulated by drawing down the reservoir 80 feet, which would yield 14,700 acre-feet of storage. A drawdown of 40 feet would yield 8,500 acre-feet of stored water. No accurate map of the upper part of the reservoir is available, and possibly this estimate of the capacity is low. The stored water would be used through an average head of 240 feet at this site and through a total head at proposed sites on the Umpqua and North Umpqua Rivers of 1,895 feet. The stored water could be used toward the end of the dry period, so that the loss of head in connection with the use of the natural flow would not cover a very long period. The total power that could be generated with 14,700 acre-feet of storage used through a head of 1,895 feet amounts to $20,000,000$ kilowatt-hours; but the net gain in power would be considerably less than this. In 1926 heavy rains came in November, before all the stored water would have been used, but still the net gain would have amounted to about $12,500,000$ kilowatt-hours, which is considered a fair estimate of the value of the storage at this site when the river is completely developed. As all the land in this site is owned by the Government, damages would amount simply to the rental charges 
and the value of the timber in the reservoir. If all the sites on the river below were completely developed the construction of a high dam at this site for joint power and storage would be justified. If only a small part of the head below were utilized the head at this site could be more economically developed by a conduit. It is assumed in this report that ultimately all the power on the river will be utilized and therefore that a high dam will be built at this site.

Potential power at undeveloped site $12 \mathrm{RB} 8$

[Head without drawdown, 275 feet; assumed drawdown, 80 feet; storage capacity, 14,700 acre-feet]

\begin{tabular}{|c|c|c|c|c|}
\hline & \multicolumn{2}{|c|}{ Flow in second-feet } & \multicolumn{2}{|c|}{ Horsepower } \\
\hline & $\begin{array}{l}90 \text { per } \\
\text { cent of } \\
\text { time }\end{array}$ & $\begin{array}{l}50 \text { per } \\
\text { cent of } \\
\text { time }\end{array}$ & $\begin{array}{l}90 \text { per } \\
\text { cent of } \\
\text { time }\end{array}$ & $\begin{array}{l}50 \text { per } \\
\text { cent of } \\
\text { time }\end{array}$ \\
\hline $\begin{array}{l}\text { Natural flow } \\
\text { Regulated flow } \\
\text { Regulated flow, } 1926 \text {. }\end{array}$ & $\begin{array}{l}775 \\
979 \\
\mathbf{7 4 7}\end{array}$ & $\begin{array}{l}1,300 \\
1,100 \\
915\end{array}$ & $\begin{array}{l}17,000 \\
16,200 \\
15,800\end{array}$ & $\begin{array}{l}28,600 \\
22,000 \\
20,100\end{array}$ \\
\hline
\end{tabular}

COPELAND POWER SITE (12RB 9)

The Copeland site is at mile 145.4, near the Illihe ranger station. A dam 200 feet high is proposed, a high dam being preferred to a conduit because a drawdown of 85 feet would furnish 24,800 acre-feet of storage capacity. (See pl. 16, $A$, and fig. 22.) A pressure tunnel about a mile long would lead from the dam to a point on the left bank, where the river has an altitude of 1,375 feet, giving a head at this site of 290 feet. This place appears to be an excellent site for a masonry dam. The south abutment is formed by a steep slope consisting of gray igneous rock that appears to be andesite, though it was not examined under the microscope. The north abutment is a nearly vertical cliff composed of the same material for 200 feet above the river, with basalt flows above. The exact line of contact was not exposed, but a short distance above it the basalt is cavernous and jointed. At the top of this canyon wall there is a bench half a mile wide known as Illihe. It is one of the remnants of the intracanyon basalt that formerly filled the North Umpqua Valley and is described in the section on the Soda Springs dam site. At this site the intracanyon basalt occurs on the north side of the river, indicating that the river has cut down along the contact of the south side of the lava fill with the former canyon wall. Instead of working down at the contact to its former buried channel the river was controlled by some fissure or other weak place in the andesite soon after it began cutting, so that nearly all of the new canyon is excavated in the andesite. This cutting has left most of the intracanyon basalt still in place, and thus the buried channel lies about a quarter of a mile north of the present one.

The proposed dam will rest entirely on the old andesite. A few small seeps from cracks in the andesite at the dam site indicate that the rock is slightly permeable. It is believed, however, that with ordinary care in construction practically all the seepage under and near the dam will be prevented. The serious problem in connection with this site is the amount of leakage that would take place through the basalt and the buried gravel channel under Illihe. The intake end of the channel lies somewhere under the flow line of the reservoir created by the proposed dam. The amount of this leakage would depend on the permeability of the intake area, and this can not be determined until the dam is completed. However, further study and drilling would throw 
considerable light on this question, especially if the drill holes were tested with water under pressure. As it is not feasible to prevent the leakage at the north abutment by grouting or a cut-off wall, it is desirable to build a dam that will be successful even if it leaks. A safety factor of approximately 20 second-feet of leakage is probably ample, but this is little more than a guess without the additional knowledge to be derived from test holes.
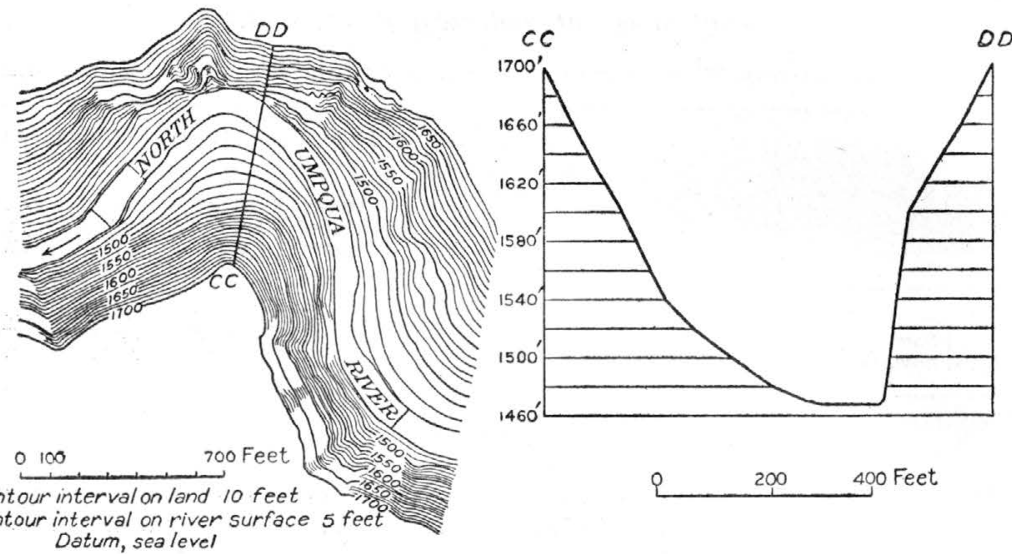

200 400 Feet

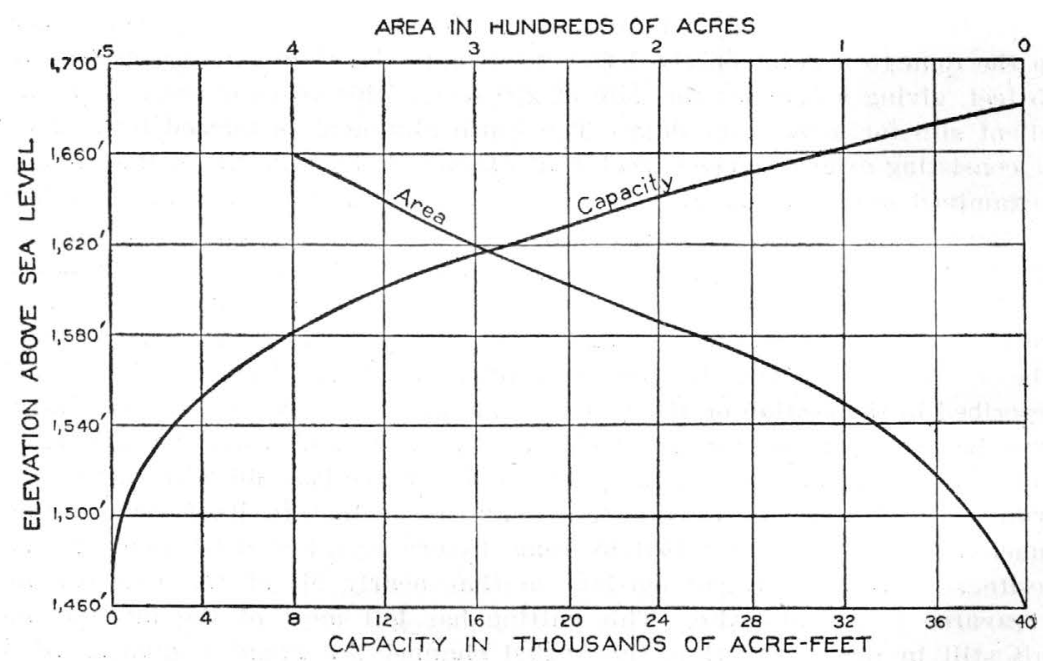

Figure 22.-Plan, cross section, and area and capacity curves, Copeland dam site, Umpqua River Basin

A dam 200 feet high will raise the water to an altitude of 1,665 feet above sea level and flood 400 acres. By drawing down the water level above the dam 85 feet 24,800 acre-feet of stored water would be obtained. This water could be used through an average head of 253 feet at this site, and a total head of 1,618 feet at all proposed plants if the head were not drawn down except at the Copeland site. The stored water would generate 4,500,000 kilowatt-hours of energy at the Copeland site and $28,000,000$ kilowatt-hours at all proposed sites if the total head at those sites could be used. But owing to loss of power due 
to loss of head at Copeland and to the decrease in head at lower sites due to drawing down the level for storage, the net gain from the use of stored water in 1926 would have amounted to $19,000,000$ kilowatt-hours. This estimate is based on the fact that the natural flow greatly increased by the end of November in 1926. If the flow remained low for December the net gain from the storage would be considerably less. But the chances are greatly in favor of a fairly large flow in December on the North Umpqua River below Steamboat Creek, and such a flow is practically certain on the Umpqua River proper. The loss of power due to loss of head at the Copeland site would average about 2,520 horsepower, and in 100 days it would equal the power obtained at the dam from the stored water. So if this site is considered by itself the head could be drawn down for storage to advantage for 61 days in September and October, assuming that the flow would increase in November. This site, however, will not be utilized until other more accessible sites below are developed, and each will add to the value of the storage that can be obtained by drawing down the head at this site.

The following estimates of regulated flow and power available show the result if the storage had been used in 1925 and 1926 to insure a uniform flow during a period of four months. This scheme does not give the best results at this site, but for the river as a whole it works out fairly well, as the power output can be equalized by the operation of the proposed large reservoir at Wolf Creek.

Summary of potential power at site 12RB 9

[Head without drawdown, 290 feet; assumed drawdown, 85 feet; storage capacity, 24,800 acre-feet]

\begin{tabular}{|c|c|c|c|c|}
\hline & \multicolumn{2}{|c|}{ Flow in second-feet } & \multicolumn{2}{|c|}{ Horsepower } \\
\hline & $\begin{array}{l}90 \text { per } \\
\text { cent of } \\
\text { time }\end{array}$ & $\begin{array}{l}50 \text { per } \\
\text { cent of } \\
\text { time }\end{array}$ & $\begin{array}{l}90 \text { per } \\
\text { cent of } \\
\text { time }\end{array}$ & $\begin{array}{l}50 \text { per } \\
\text { cent of } \\
\text { time }\end{array}$ \\
\hline $\begin{array}{l}\text { Natural flow } \\
\text { Regulated flow } \\
\text { Regulated flow, } 1926 .\end{array}$ & $\begin{array}{r}825 \\
1,020 \\
757\end{array}$ & $\begin{array}{l}1,400 \\
1,280 \\
940\end{array}$ & $\begin{array}{l}19,100 \\
18,900 \\
17,400\end{array}$ & $\begin{array}{l}32,400 \\
32,400 \\
21,800\end{array}$ \\
\hline
\end{tabular}

\section{STEAMBOAT POWER SITE (12RB 10)}

The dam site for the Steamboat power project is at mile $1371 / 2,21 / 2$ miles above the mouth of Steamboat Creek. A concrete dam 190 feet high, which would raise the water level to an altitude of 1,375 feet, is proposed. (See pl. 21, $A$, and fig. 23.) The reservoir would help to smooth out the peak flow of floods, as a rise of 1 foot would store a flow of 4,300 second-feet for 1 hour.

At this site the river has cut through what appears to be a thick riabase sill intruded into volcanic agglomerate. The walls of the canyon are steep and rugged, and rock is well exposed. It strikes N. $72^{\circ} \mathrm{W}$. and dips $18^{\circ} \mathrm{NE}$. The diabase is a member of an old formation, probably of Eocene age. There are cnough joints to cause some seepage under and around the dam, hence it will probably pay to grout the foundations to prevent leakage. The rock is strong and forms a satisfactory dam site. As the seepage at this site will not affect the stability of the dam nor increase with time, it might even be disregarded with safety. The site is a considerable distance downstream from Illihe, the last large remnant of intracanyon basalt, hence there need be no fear of buried channels on either side of the river.

A dam 190 feet high would flood 365 acres, and by drawing down the water 75 feet 19,000 acre-feet of stored water would be obtained. This water could 
be used through an average head of 155 feet at the dam and a maximum head of 1,330 feet at all proposed plants on the river if there were no drawdown except at this site. The stored water would generate $2,000,000$ kilowatt-hours of energy at the dam and 18,000,000 kilowatt-hours at all proposed plants if there were no drawdown except at Steamboat. But owing to loss of head at this and other sites the net gain from the use of the stored water would amount to only about 11,000,000 kilowatt-hours, which would have been the net gain in 1926 . The loss of head at the dam due to the drawdown would average 35 feet, and the low flow in an average year with storage in Diamond Lake rould amount to
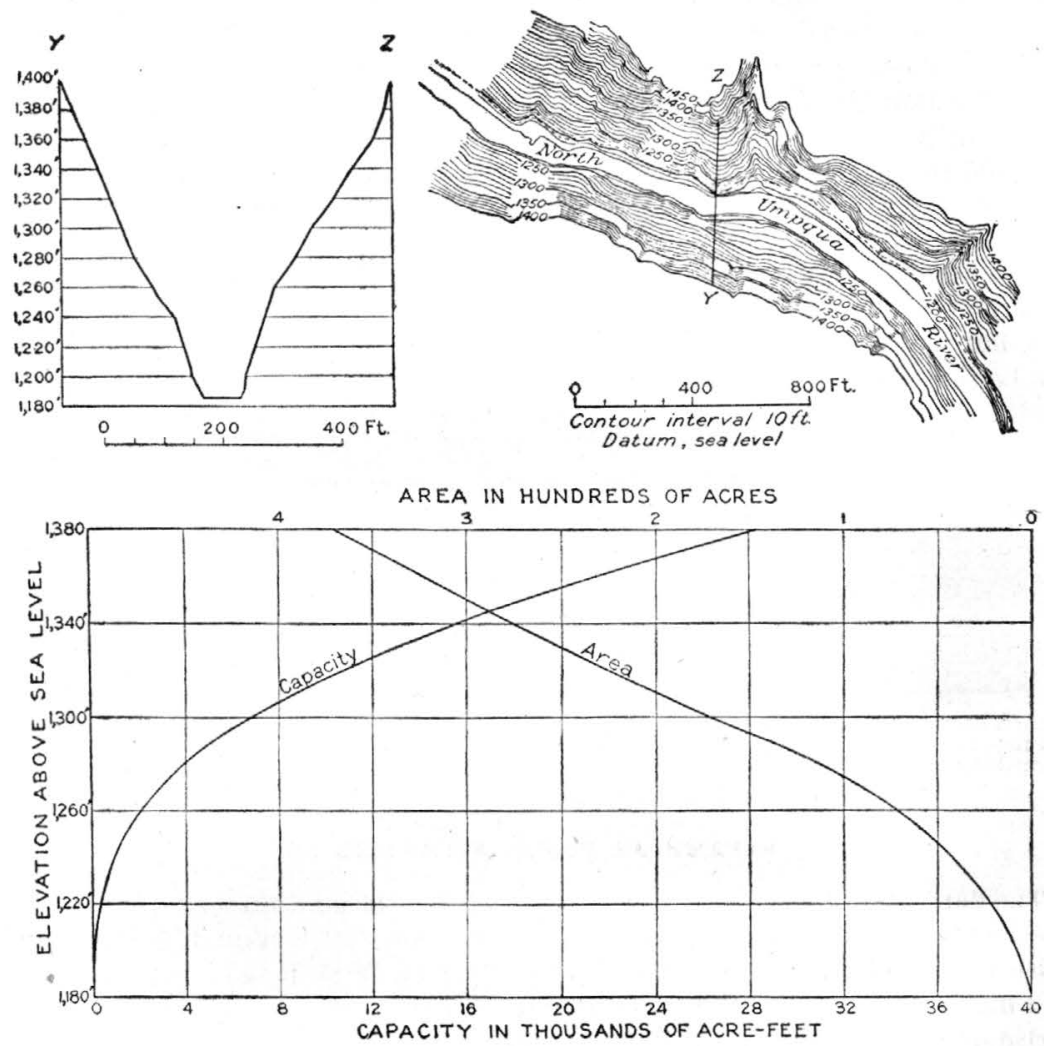

FIGURE 23.-Plan, cross section, and area and capacity curves, Steamboat dam site, Umpqua River Basin

about 900 second-feet. The loss of power due to loss of head would amount to 2,520 horsepower, which would equal the power obtained at the dam from stored water in 47 days. If there were no other plants below, the economical drawdown at this site would be less than 75 feet, probably around 40 feet. But other sites farther downstream will be developed before this site is utilized, and the value of the stored water will be proportionally increased. If the Boundary and Rock Creek sites were developed they would increase the value of stored water to such an extent that it probably would pay to draw the head down the full amount proposed. However, the question just how far the head could be economically drawn down is very complicated, and the answer would depend on the conditions at the time it was proposed. 
In computing the power available at this site with storage it is assumed that all sites above will have been developed and that the storage capacity at this site will be used to equalize the flow in August, September, October, and November.

Summary of potential power at site $12 \mathrm{RB} 10$

[Head without drawdown, 190 feet; assumed drawdown, 75 feet. Storage capacity, 19,000 acre-feet]

\begin{tabular}{|c|c|c|c|c|}
\hline \multirow[t]{2}{*}{. } & \multicolumn{2}{|c|}{ Flow in second-feet } & \multicolumn{2}{|c|}{ Horsepower } \\
\hline & $\begin{array}{l}90 \text { per } \\
\text { cent of } \\
\text { time }\end{array}$ & $\begin{array}{l}50 \text { per } \\
\text { cent of } \\
\text { time }\end{array}$ & $\begin{array}{l}90 \text { per } \\
\text { cent of } \\
\text { time }\end{array}$ & $\begin{array}{l}50 \text { per } \\
\text { cent of } \\
\text { time }\end{array}$ \\
\hline $\begin{array}{l}\text { Natural flow } \\
\text { Regulated flow } \\
\text { Regulated flow, } 1926 \text {. }\end{array}$ & $\begin{array}{r}850 \\
1,050 \\
767\end{array}$ & $\begin{array}{l}1,500 \\
1,320 \\
965\end{array}$ & $\begin{array}{l}12,900 \\
11,900 \\
11,700\end{array}$ & $\begin{array}{l}22,800 \\
20,100 \\
14,700\end{array}$ \\
\hline
\end{tabular}

BOUNDARY POWER SITE (12RB 11)

A dam 225 feet high is proposed at the Boundary site, which is near the west boundary of the Umpqua National Forest, 1 mile below Fall Creek, in the NW. 1/4 sec. 17, T. 26 S., R. 1 W., on the North Umpqua River. (See pl. 21, B.)

This dam site is in a canyon about 500 feet deep with nearly vertical cliffs of columnar-jointed lava rock 300 feet high. A specimen from this site was determined under the microscope by C. S. Ross, of the United States Geological Survey, to be andesite. It contains large crystals of glassy feldspar in a dark groundmass. It is very similar to the porphyritic andesite of the Rock Creek site. Not all the jointing in the canyon walls is vertical, for some of it is nearly horizontal or lies at intermediate angles.

Drilling by the California-Oregon Power Co. was in progress at this site in 1926, and Mr. E. C. Koppen furnished the available logs. Surprising as it may seem, the immense igneous mass that forms the canyon at this place has been nearly sawed through by the river. One drill hole 85 feet deep had been completed on the north bank of the river at the time of visit. This hole passed through the andesite in 28 feet and encountered a bed of gray basalt 27 feet thick, beneath which lay 23 feet of black shaly tuff and agglomerate. A hole inclined $45^{\circ}$ had just been started in the river bed. The log of the completed hole is given in the table below:

Log of hole No. 1 of Boundary dam site, North Umpqua River

\begin{tabular}{|c|c|c|}
\hline & Thickness & Depth \\
\hline $\begin{array}{l}\text { Columnar andesite. } \\
\text { Black shaly tuffe } \\
\text { Basalt } \\
\text { Shaly tuff (?) } \\
\text { Basalt } \\
\text { Hard black tuff } \\
\text { Agglomerate }\end{array}$ & Feet $\begin{array}{r} \\
28 \\
3 \\
2 \\
2 \\
27 \\
8 \\
15\end{array}$ & Feet \\
\hline
\end{tabular}

It is evident that the basalt between 35 and 62 feet in this hole is a sill and has been intruded into the sediments. The 2 -foot bed of basalt above it is probably a thin offshoot from this sill. The massive andesite that would form the abutments of the dam site is probably a sill also, although this 
fact was not determined by following it upstream. Regardless of the origin of the andesite, it is a strong and relatively impermeable mass and would form very satisfactory abutments. If this rock has been entirely removed in the bed of the river the dam will have to be founded on the basalt sill. Such a foundation will be satisfactory, and it is believed that seepage under such conditions will be small. Because the structure in the valley in general dips upstream it might be expedient to build at a site a few hundred feet upstream, where the andesite will form the foundation as well as the abutments of the proposed dam.

The following table shows the area and capacity of the reservoir that would be created by dams of different heights :

Area and capacity of Boundary reservoir

\begin{tabular}{|r|r|r||r|r|r|}
\hline $\begin{array}{c}\text { Altitude } \\
\text { above } \\
\text { sea level } \\
\text { (feet) }\end{array}$ & $\begin{array}{c}\text { Area } \\
\text { (acres) }\end{array}$ & $\begin{array}{c}\text { Capacity } \\
\text { (acre- } \\
\text { feet) }\end{array}$ & $\begin{array}{r}\text { Altitude } \\
\text { above } \\
\text { sea level } \\
\text { (feet) }\end{array}$ & $\begin{array}{c}\text { Area } \\
\text { (acres) }\end{array}$ & $\begin{array}{c}\text { Capacity } \\
\text { (acre- } \\
\text { feet) }\end{array}$ \\
\hline 957 & 0 & 0 & 1,060 & 245 & 10,270 \\
960 & 2 & 3 & 1,080 & 387 & 16,590 \\
980 & 28 & 303 & 1,100 & 475 & 25,210 \\
1,000 & 72 & 1,300 & 1,140 & 675 & 48,000 \\
1,020 & 110 & 3,120 & 1,180 & 890 & 79,000 \\
1,040 & 180 & 6,020 & & & \\
\hline
\end{tabular}

- Estimated.

A dam 225 feet high at this site would raise the water surface to 1,180 feet above sea level and flood 890 acres. By drawing down the water surface 100 feet, 62,000 acre-feet of stored water would be obtained. This water could be used through an average head of 182 feet at the dam and a total head at all plants of 1,132 feet. The stored water would generate $8,000,000$ kilowatthours at the dam and 51,000,000 kilowatt-hours at all sites if there were no drawdown at the sites below Boundary. In practice, of course, the water level would be drawn down at the lower sites, as well as at Boundary, and the net gain from the use of the stored water in 1926 would have been $36,000,000$ kilowatt-hours. The average loss of head at Boundary would amount to 43 feet, and the minimum flow with storage in Diamond Lake in an ordinary year would amount to about 1,000 second-feet. The average loss of power due to loss of head would amount to 3,440 horsepower, and in 132 days the loss of power due to loss of head would equal the gain in power at the dam site due to drawing down the reservoir. If there were no plants below, only the upper part of the reservoir would be drawn down for storage. A drawdown of 40 feet would provide 31,000 acre-feet of storage, and the average loss of head would be about 19 feet. The stored water would generate 258,000 horsepower-days of power at the Boundary power site, and here the average loss of power due to loss of head would be 1,520 horsepower. In 123 days the loss of power would amount to 187,000 horsepower-days. Thus the power output for the four summer months could be equalized and the net power output at the site increased 577 horsepower by drawing down the reservoir. With one or two additional plants below it would pay to draw down at least 80 feet. The principal value of this storage, in fact, would be at plants below, whether one or all were developed. If the Rock Creek site had been developed to a head of 115 feet 40,000 acre-feet released from Boundary would have increased the mean potential power 1,530 horsepower for the four low months of August to November, 1925, besides equalizing the output during those months. 
In 1926 the natural flow was lower, the loss of power at Boundary due to loss of head would have been less, and the net gain due to the use of the water stored in the upper 100 feet of the reservoir would have amounted to 725 horsepower. This gain assumes that no storage was available except at the Boundary site and that the stored water would have been used over a period of 135 days.

If this plant were operating as a single unit the reservoir would not be drawn down so low and the power output would be equalized over the low period rather than the stream flow. In estimating the potential power of the river it is assumed that the storage at Coles Valley will be used to equalize the power output of the system and that the stream flow at Boundary will be equalized for the period July to November. Ordinarily there will be a rise late in November or in December and no shortage of power in those months.

Summary of potential power at site 12RB 11

[Head without drawdown, 225 feet; assumed drawdown, 100 feet; storage capacity, 62,000 acre-feet]

\begin{tabular}{|c|c|c|c|c|}
\hline . & \multicolumn{2}{|c|}{ Flow in second-feet } & \multicolumn{2}{|c|}{ Horsepower } \\
\hline . & $\begin{array}{l}90 \text { per } \\
\text { cent of } \\
\text { time }\end{array}$ & $\begin{array}{l}50 \text { per } \\
\text { cent of } \\
\text { time }\end{array}$ & $\begin{array}{l}90 \text { per } \\
\text { cent of } \\
\text { time }\end{array}$ & $\begin{array}{l}50 \text { per } \\
\text { cent of } \\
\text { time }\end{array}$ \\
\hline $\begin{array}{l}\text { Natural flow } \\
\text { Regulated flow, } \\
\text { Regulated flow, } 1926\end{array}$ & $\begin{array}{r}890 \\
1,450 \\
1,120\end{array}$ & $\begin{array}{l}1,800 \\
1,950 \\
1,230\end{array}$ & $\begin{array}{l}16,000 \\
18,200 \\
14,800\end{array}$ & $\begin{array}{l}32,400 \\
32,400 \\
20,100\end{array}$ \\
\hline
\end{tabular}

\section{CLARK RANCH POWER SITE (12RB 12)}

An excellent dam site is found at the Clark ranch in the NE. $1 / 4$ sec. 21, T. 26 S., R. 2 W., at mile 1221/2. A dam 110 feet high would back water within 5 feet of the Boundary site above. (See pl. 22, $A$, and fig. 24.) It is possible that the dam at the Rock Creek site will be high enough to drown out this site. In that case a site might be found farther upstream, although there is no site as favorable as this one between it and the Boundary site. If a dam site could not be found the power could be developed by a conduit.

There are two possible locations for a dam at this place-an upper one on line $W-X$ (fig. 24) and a lower one on line $Y-Z$.

The geology of the two sites is shown in plan on Figure 24. The boundaries of the geologic formations are shown by dotted lines on the south side of the river, because the river could not be forded at the time of the examination, and hence the boundaries were sketched from the north side. The geology of the upper site is very simple, for massive, compact green volcanic agglomerate dipping upstream at an angle of $15^{\circ}$ crops out on both sides and lies at a shallow depth below the surface of the water. A hundred feet upstream from this site occurs a diabase dike 5 feet wide that dips $75^{\circ} \mathrm{S}$. Where it crosses the North Umpqua River it forms a riffle. The rock at this site is sufficiently strong to support the proposed 110-foot dam. It is relatively impermeable, so that no difficulty should be experienced with leakage under or around the dam. The nearly vertical dike 100 feet upstream is also an impermeable wall and absolutely cuts off leakage from the reservoir. The site is excellent and far better than those upstream from it. However, the lower dam site is even superior to the upper one. It is formed by the outcrop of a dense diabase sill about 70 feet thick intruded into the volcanic agglomerate. The diabase crops out on both banks and in the river bed and is a much more 

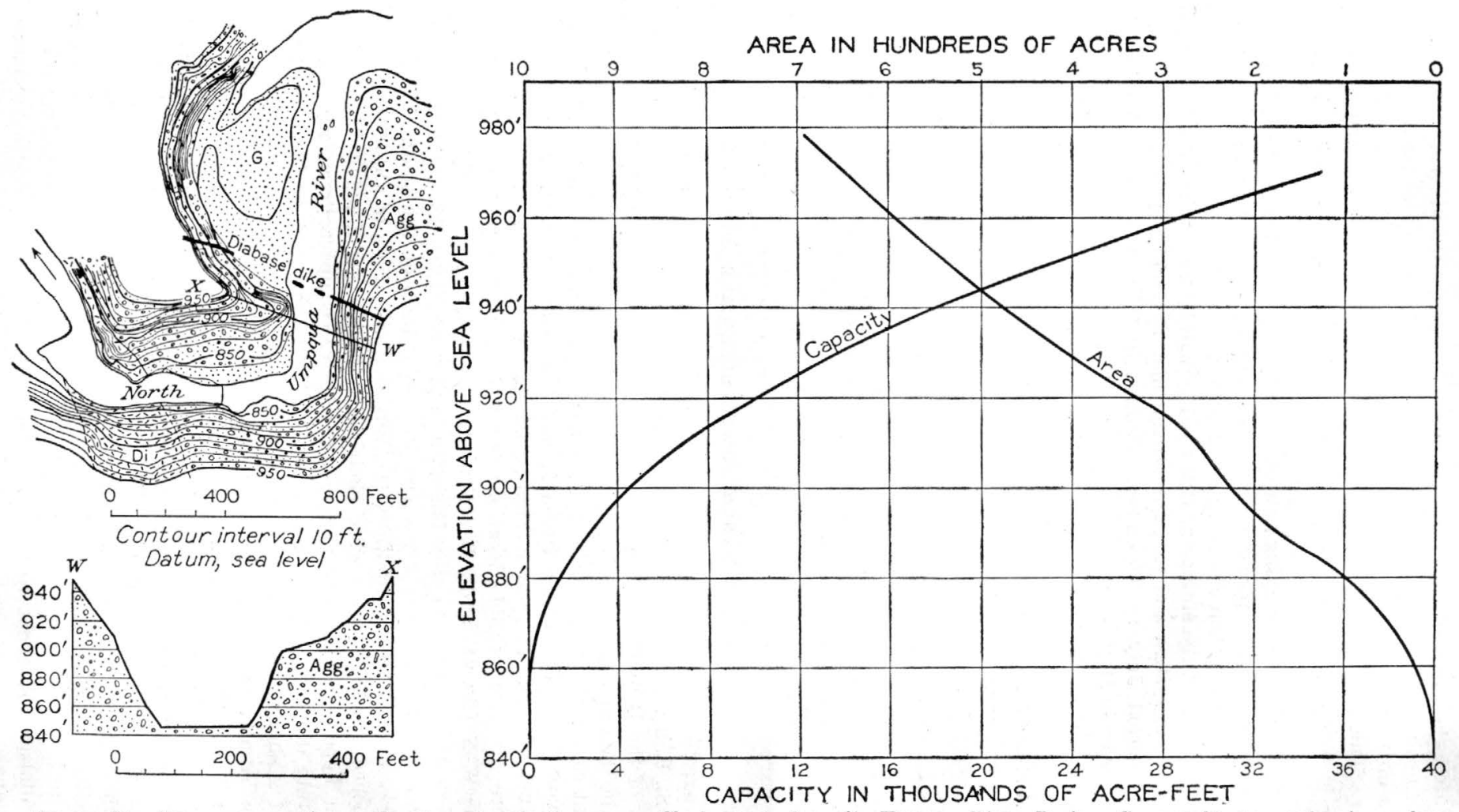


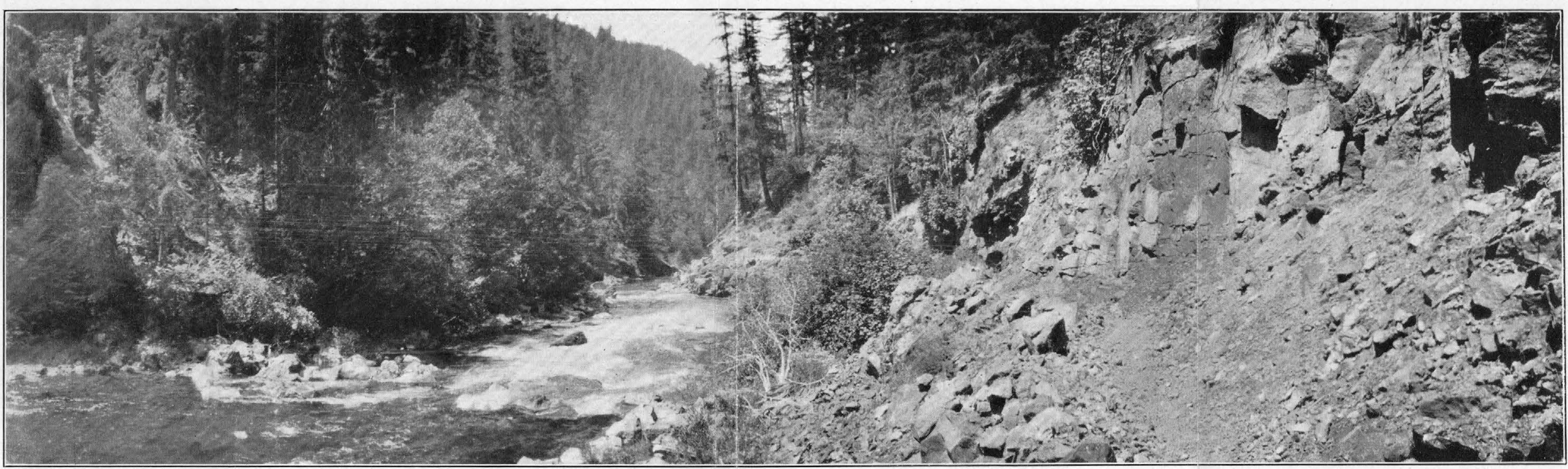

A. UPPER END OF STEAMBOAT DAM SITE, UMPQUA RIVER BASIN

Looking downstream.

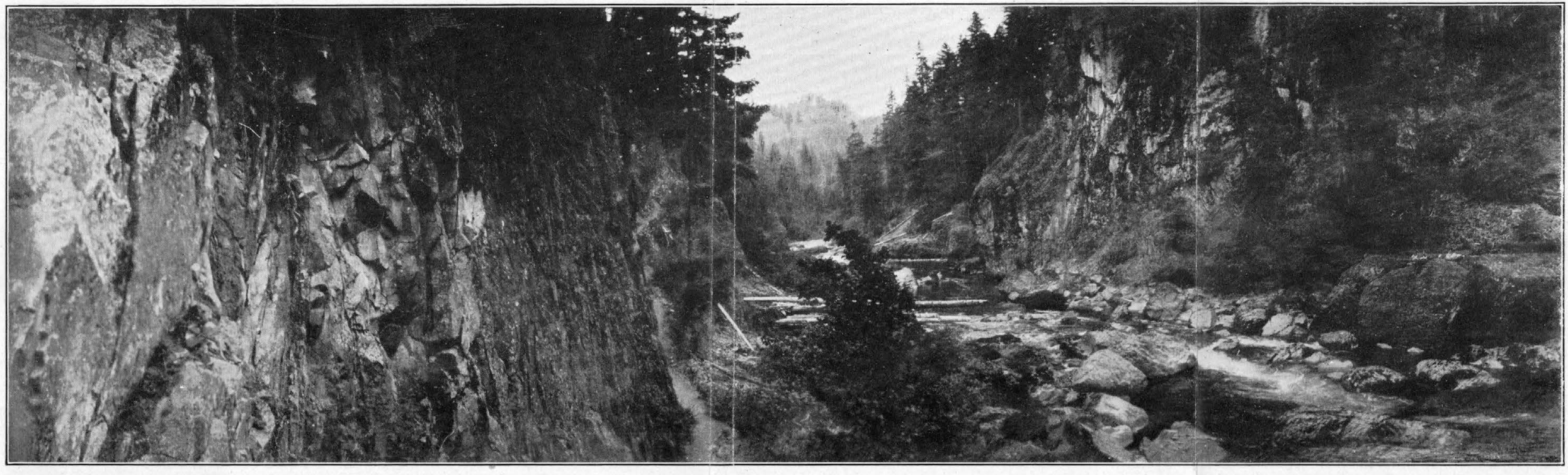

B. BOUNDARY DAM SITE, UMPQUA RIVER BASIN 


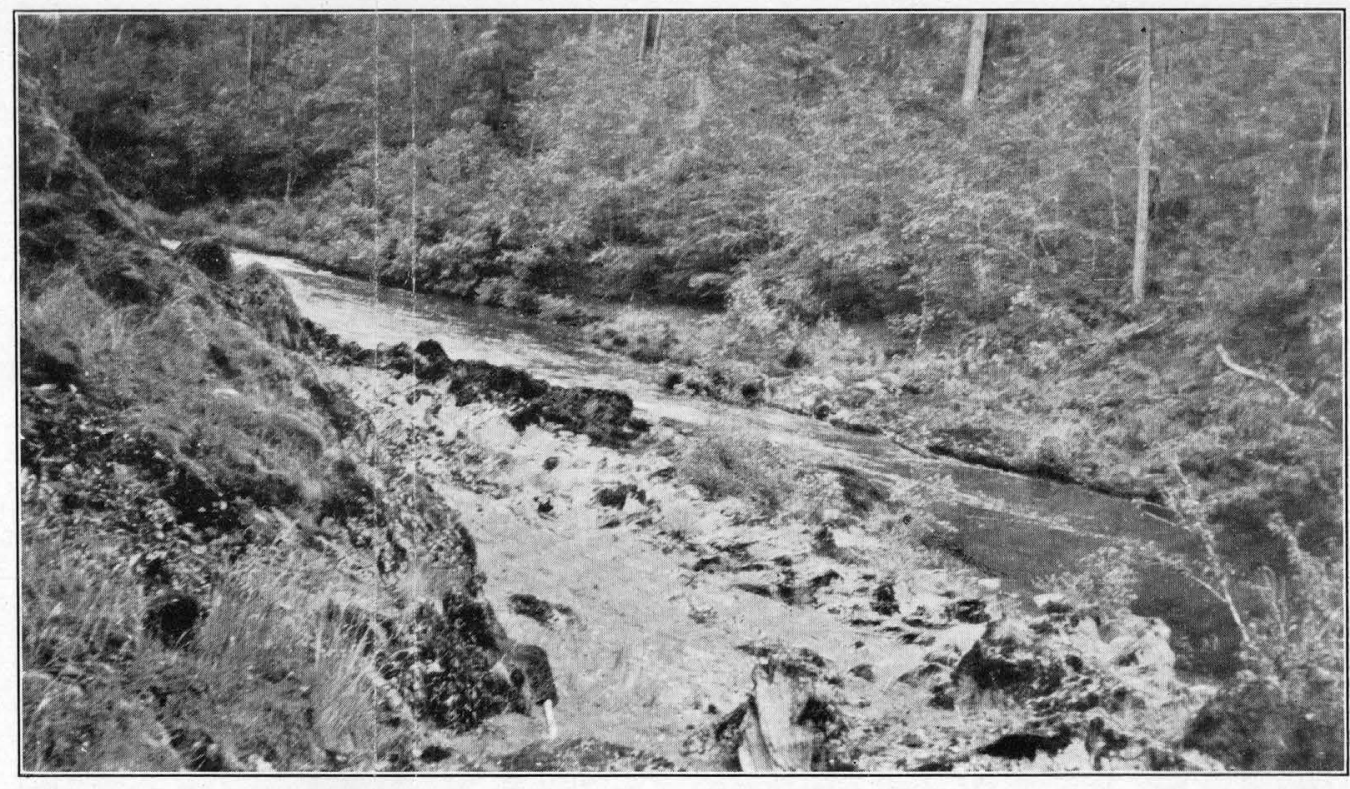

A. CLARK RANCH DAM SITE, UMPQUA RIVER BASIN

Looking upstream.

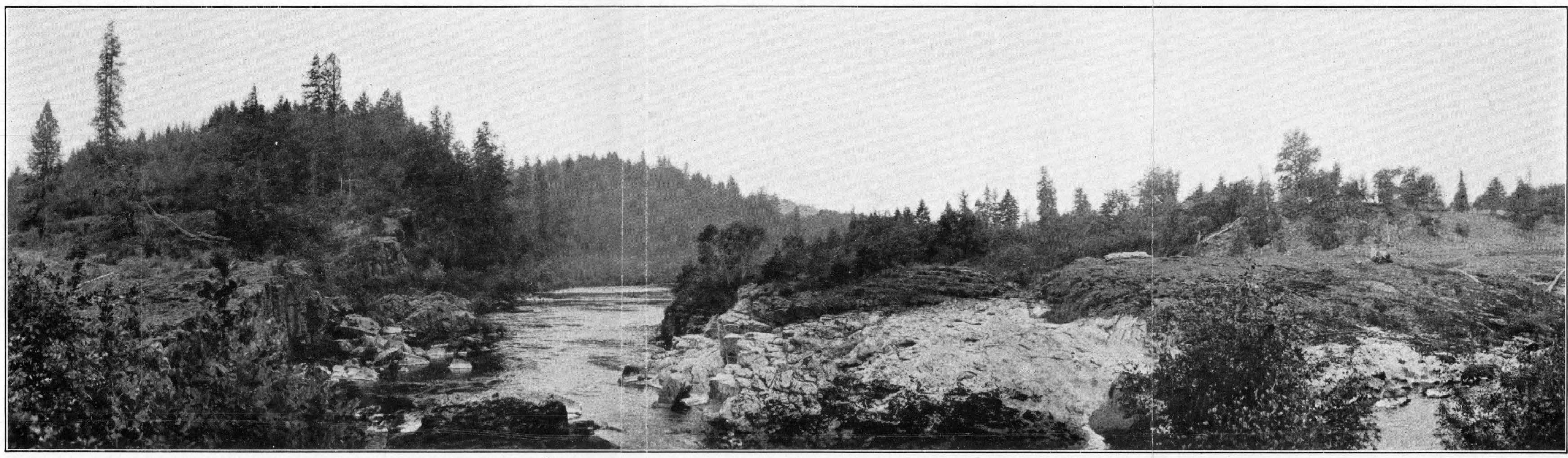

B. GLIDE DAM SITE, UMPQUA RIVER BASIN

Looking downstream. 




A. HORSESHOE BEND DAM SITE, UMPQUA RIVER BASIN

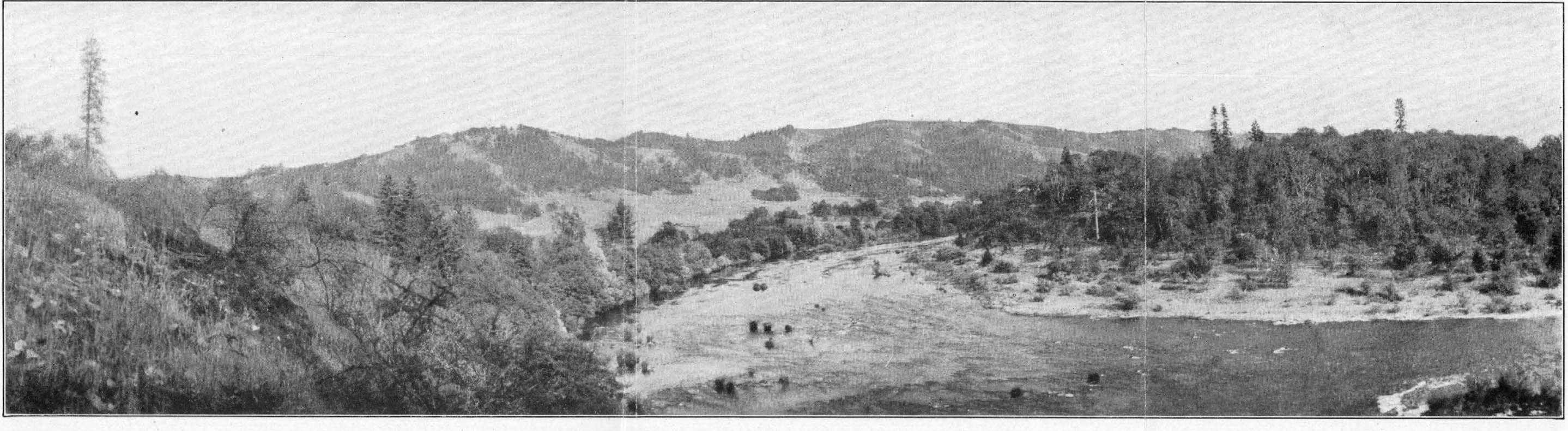

B. OAK CREEK DAM SITE, UMPQUA RIVER BASIN

View from right bank, looking upstream. 


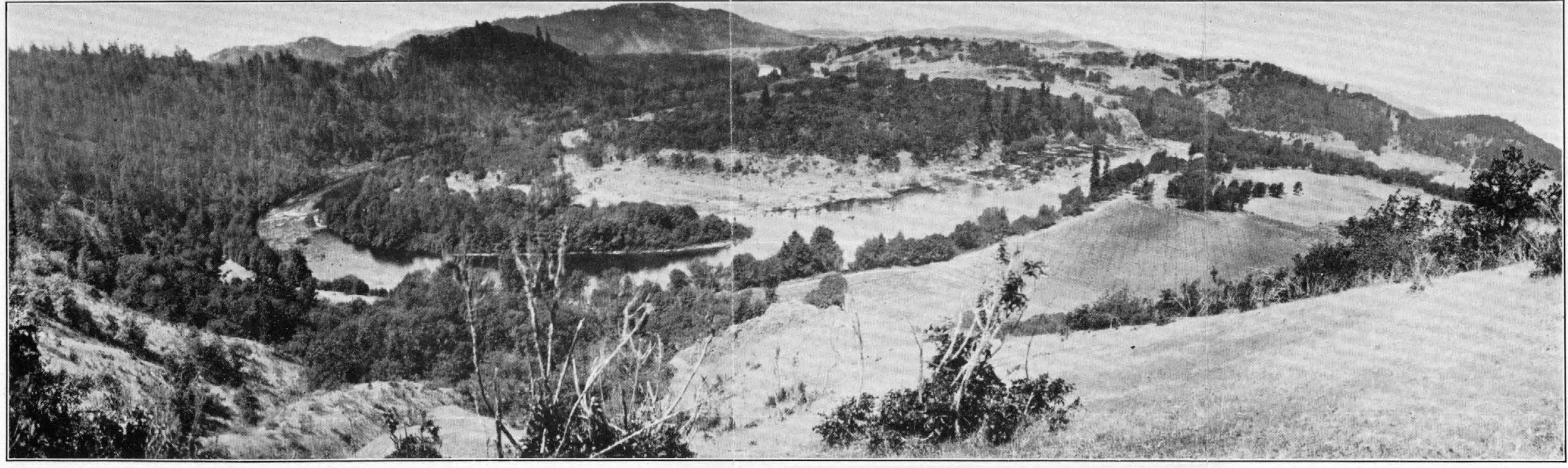

A. WINCHESTER DAM SITE, UMPQUA RIVER BASIN

Shows rock in river channel.

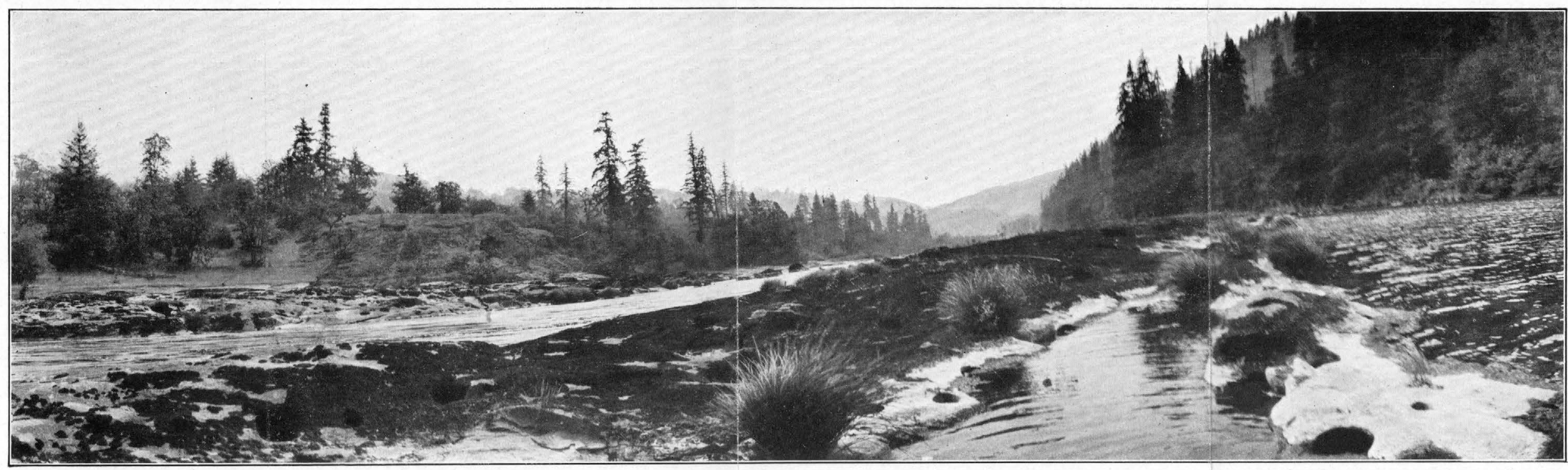

B. KELLOGG DAM SITE, UMPQUA RIVER BASIN View from left bank. 
satisfactory rock than the agglomerate to key in the proposed dam. It has a higher crushing strength, is a much firmer rock, and is less permeable. The agglomerate is a deposit of volcanic ash and ejectamenta consolidated by time, whereas the diabase is an intrusive rock. Moreover, the 5-foot dike upstream from the upper site would afford the same protection against seepage losses from a reservoir formed by a dam at the lower site. For these reasons it is recommended that the lower site be developed.

A dam about 110 feet high at this site would raise the water surface to an altitude of 955 feet and flood 565 acres. By drawing down the water surface 35 feet 16,000 acre-feet of stored water could be obtained. This water could be used through an average head of 95 feet at the dam and a total head of 935 feet at all proposed plants if there were no drawdown except at this site. Under these conditions the stored water would generate $1,000,000$ kilowatt-hours of power at the dam and 11,000,000 kilowatt-hours at all proposed sites; but owing to drawdown at other sites and loss of power due to loss of head at this site the net gain from the stored water in 1926 would have been about 7,000,000 kilowatt-hours, which is assumed to be a rough approximation of the value of this stored water. The loss of head due to drawing down the reservoir surface would amount to $15 \mathrm{feet}$, and the low-water flow with storage in Diamond Lake would amount to about 1,000 second-feet. The average loss of power due to loss of head would amount to 1,200 horsepower. This loss would equal the power obtained from the stored water at this site in $\mathbf{5 1}$ days, or less than two months. If no other sites were developed below, the reservoir capacity could be used to equalize the monthly flow and to increase the flow in a very dry month. If the river were completely developed it probably would not pay to draw down the head at this plant before September, because of the small amount of storage. It has been assumed that the stored water would be used during September, October, and November, but that ordinarily little water would be required in November.

Summary of potential power at site 12RB 12

[Head without drawdown, 110 feet; assumed drawdown, 35 feet; storage capacity, 16,000 acre-feet]

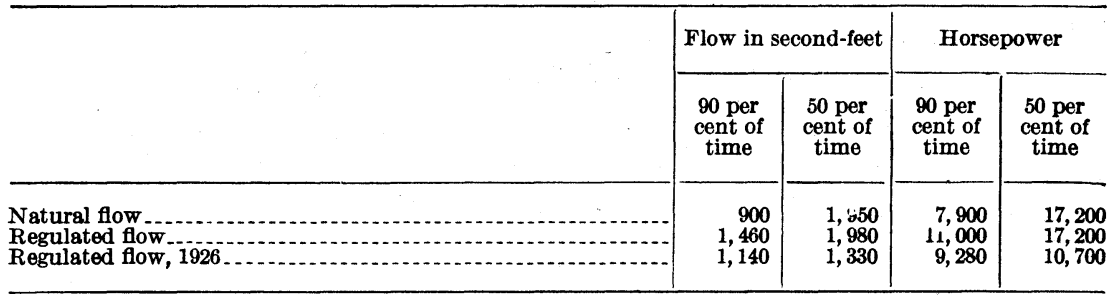

Owing to the loss of head caused by drawing down the water for storage, the potential power for 50 per cent of the time is the same for natural and regulated flow, although the estimated regulated flow is somewhat greater.

\section{ROCK CREEK POWER SITE (12RB 18)}

The Rock Creek dam site is about a mile above Rock Creek, in the vicinity of mile 119, in sec. 12, T. $26 \mathrm{~S}$., R. $3 \mathrm{~W}$. The dam proposed in this report would be 60 feet high, and a conduit through the bend in the river below would increase the head at the power house to 120 feet. It would not pay to draw down 
the head at this site except temporarily on account of load factor or in order to equalize small changes in daily discharge.

The following table shows the area which would be overflowed and the capacity of the reservoir for dams raised to different altitudes:

Area and capacity of Rock Oreek reservoir

\begin{tabular}{|c|c|c|c|c|c|}
\hline $\begin{array}{l}\text { Aliitude } \\
\text { above } \\
\text { sea level } \\
\text { (feet) }\end{array}$ & $\begin{array}{c}\text { Area } \\
\text { (acres) }\end{array}$ & $\begin{array}{l}\text { Capacity } \\
\text { (acre- } \\
\text { feet) }\end{array}$ & $\begin{array}{l}\text { Altitude } \\
\text { above } \\
\text { sea level } \\
\text { (feet) }\end{array}$ & $\begin{array}{c}\text { Area } \\
\text { (acres) }\end{array}$ & $\begin{array}{l}\text { Capacity } \\
\text { (acre- } \\
\text { feet) }\end{array}$ \\
\hline $\begin{array}{l}780 \\
800 \\
820\end{array}$ & $\begin{array}{r}0 \\
46 \\
93\end{array}$ & $\begin{array}{r}0 \\
480 \\
1,870\end{array}$ & $\begin{array}{l}840 \\
860 \\
880\end{array}$ & $\begin{array}{l}189 \\
304 \\
436\end{array}$ & $\begin{array}{r}4,690 \\
9,620 \\
17,000\end{array}$ \\
\hline
\end{tabular}

During the investigation of the geology at this site the California-Oregon Power Co. was testing the site by means of drill holes, and the details of the concealed rocks are known through the courtesy of Mr. E. C. Koppen, who permitted examination of the cores.

The river at low stages at the site flows in a narrow channel cut in a sill of gray igneous rock, which has been identified under the microscope by $C$. $s$. Ross, of the United States Geological Survey, as a porphyritic andesite. The sill was formed by the intrusion of the andesite into beds of volcanic tuff and agglomerate. The beds strike N. $22^{\circ}$ E. and dip $12^{\circ}$ SE. The dip is nearly upstream, hence leakage along bedding planes is not likely.

The andesite sill crops out all the way across the floor of the valley, except in the low-water channel, and disappears on both banks under a cover of agglomerate. It is about 65 feet thick, and a few hundred feet downstream from the site the contacts of the sill and the underlying beds are well exposed. The contacts are extremely tight and are so impermeable that seepage will not occur through them. The drill, however, did not penetrate any of the andesite in the river but encountered soft shale, which occurs beneath the sill. It so happens that the river has cut completely through the sill at this site.

Drill hole No. 1 is near the road on the north side of the river at the site, at an altitude of $\mathbf{7 8 4}$ feet above sea level. It is $\mathbf{1 1 8}$ feet deep and was started in the andesite sill about 15 feet above the river. The following log of this hole is based solely upon a megascopic examination of the core.

Log of hole No. 1 of Rock Creek dam site on North Umpqua River

[Altitude, 784 feet]

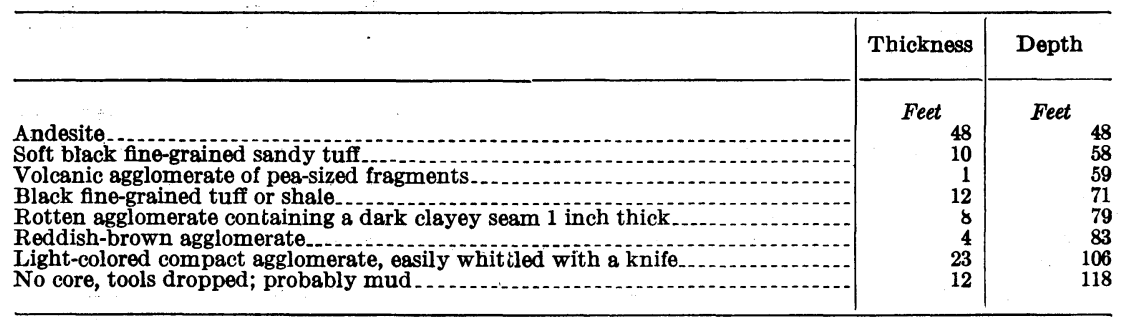

Hole No. 2 is in the river at the site, about 15 feet lower than hole No. 1. The core was not examined, but the record given was furnished by Mr. Koppen: 
Log of hole No. 2 of Rock Creek dam site on North Umpqua River

[Altitude, about 770 feet]

\begin{tabular}{|c|c|c|}
\hline & Thickness & Depth \\
\hline $\begin{array}{l}\text { Water } \\
\text { Boulders } \\
\text { Tund and agglomerate, similar to that in hole No } \\
\text { Hard black basalt. } \\
\text { Agglomerate. }\end{array}$ & Feet $\begin{array}{r} \\
21 \\
15 \\
10 \\
52 \\
3 \\
5\end{array}$ & Feet $\begin{array}{r} \\
21 \\
36 \\
46 \\
98 \\
101 \\
106\end{array}$ \\
\hline
\end{tabular}

About 500 feet upstream from hole No. 1, at an altitude of 779 feet above sea level, hole No. 3 was drilled. It is $\mathbf{8 6}$ feet deep and was drilled entirely in hard, coarse gray volcanic agglomerate. This hole did not penetrate the sill because it was not drilled deep enough. This same bed of hard agglomerate crops out on a massive ledge on both banks above the sill at the dam site.

Hole No. 4 was drilled in the river near hole No. 3 and penetrated the same rock. About 50 feet upstream from hole No. 3 another sill consisting of a ledge of basalt 25 feet thick and dipping upstream crops out and forms rapids in the river. A short distance above this sill is still another one, about $\mathbf{1 0 0}$ feet thick. A series of soft tuffs overlies this last sill. Evidently there is a series of beds of volcanic débris in this area, which contain a number of sills. The formation is relatively impermeable but of very unequal hardness.

Because the tuffs underlying the andesite sill at the lower end of the dam site are soft, and because these same soft beds lie directly below the channel alluvium, it is inadvisable to construct a dam at this lower site. The thick bed of coarse, hard agglomerate cropping out in the river bed 500 feet upstream forms a satisfactory foundation for a dam. A few joints in this bed would allow slight seepage here and there, but in amounts too small to be serious. The rock is not soluble in cold dilute hydrochloric acid, hence there is no danger of these joints enlarging by solution. The section is wider at this upper site than at the lower one, but the fact that bedrock occurs in the river offsets this disadvantage. The abutments are composed of massive conglomerate with an intercalated diabase sill and are covered with shallow soil. The upper site is entirely satisfactory for the proposed dam.

Summary of potential power at site $12 R B 13$

[Head, 120 feet]

\begin{tabular}{|c|c|c|c|c|}
\hline \multirow{2}{*}{$\cdot$} & \multicolumn{2}{|c|}{ Flow in second-feet } & \multicolumn{2}{|c|}{ Horsepower } \\
\hline & $\begin{array}{l}90 \text { per } \\
\text { cent of } \\
\text { time }\end{array}$ & $\begin{array}{l}50 \text { per } \\
\text { cent of } \\
\text { time }\end{array}$ & $\begin{array}{l}90 \text { per } \\
\text { cent of } \\
\text { time }\end{array}$ & $\begin{array}{l}50 \text { per } \\
\text { cent of } \\
\text { time }\end{array}$ \\
\hline $\begin{array}{l}\text { Natural flow } \\
\text { Regulated flow } \\
\text { Regulated flow, } 1926\end{array}$ & $\begin{array}{r}900 \\
1,460 \\
1,140\end{array}$ & $\begin{array}{r}2,000 \\
1,980 \\
1,330\end{array}$ & $\begin{array}{r}8,640 \\
14,000 \\
11,000\end{array}$ & $\begin{array}{l}19,200 \\
19,000 \\
12,700\end{array}$ \\
\hline
\end{tabular}

GIIDE POWER SITE (12RB 14)

There is an excellent dam site in sec. 19, T. 26 S., R. 3 W., at the mouth of the Little River at Glide. The only disadvantage of the site is the fact that the land which would be overflowed is largely in private ownership, and 

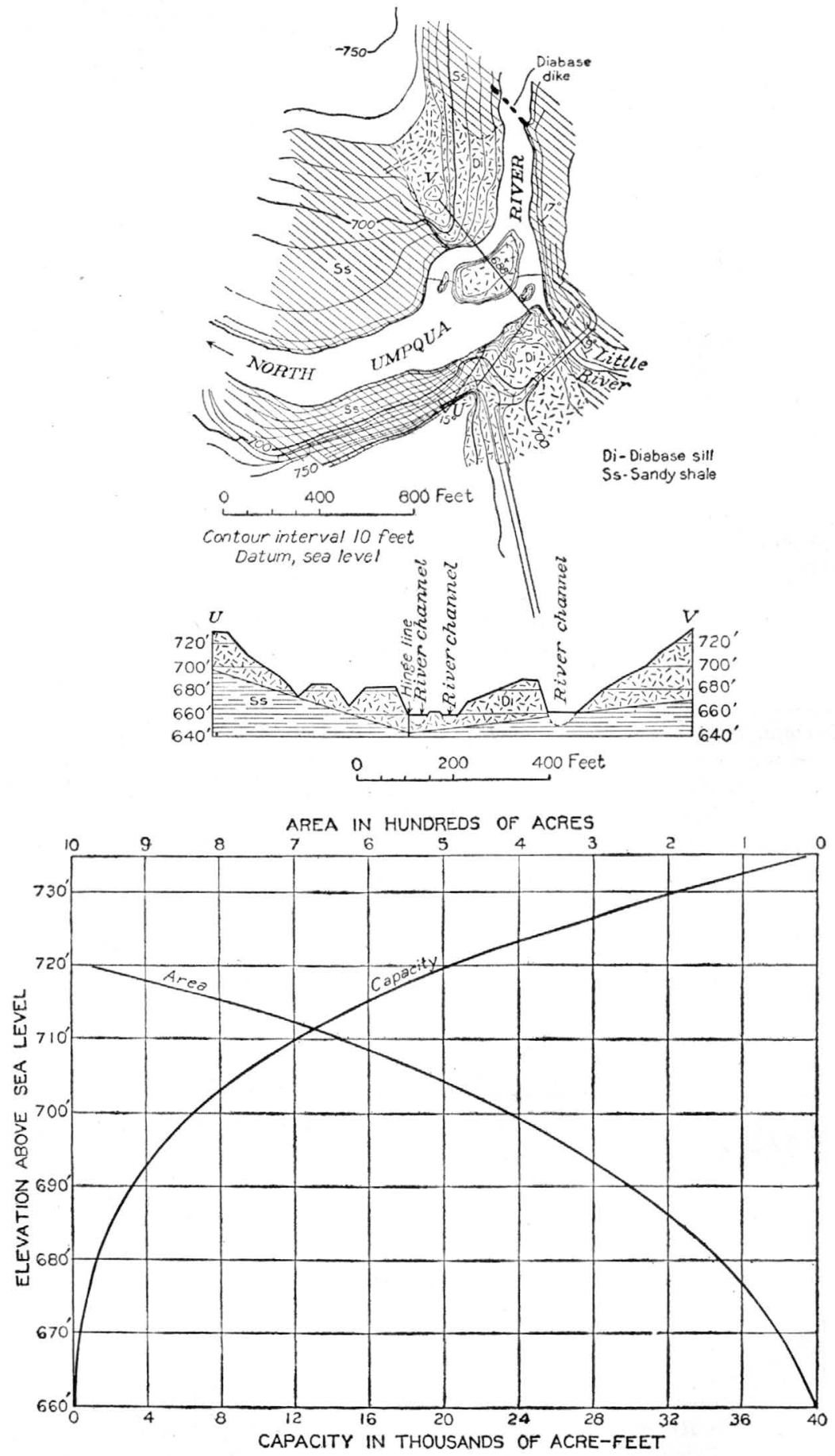

Figure 25,-Plan, cross section, and area and capacity curves, Glide dam site, Umpqua River Basin 
the damages would be considerable. A dam 60 feet high is proposed at this site. (See pl. 22, $B$, and fig. 25.)

It is feasible to build an open conduit from this dam site to the location of the proposed Horseshoe Bend power plant, thus increasing the head from 60 to 150 feet. The canal would be 7 miles long. The flow for 50 per cent of the time at this site is 2,400 second-feet, but it probably would not pay to build the canal to so large a capacity. As there is a fairly good dam site at Horseshoe Bend the head can probably be developed to best advantage by means of a dam.

The maximum recorded peak flow at the Oak Creek gaging station, not far below this site, was 90,000 second-feet, on November 23, 1909.

A detailed topographic survey, a geologic map, and a geologic cross section of the site are shown on Figure 25. The falls at the site are made by the outcrop of a diabase sill that is intruded into sandstone and shale of the Umpqua formation. ${ }^{2}$ A bed of fossils of Eocene age occurs in the sandstone under the highway bridge on the north bank of the Little River. The sill is about 25 feet thick where it crosses the road on the south bank and is underlain at this place by soft, black, sandy shale. The sill thickens on the north side of the river and finally disappears under sedimentary rock. The river, at the site probably flows on the shale underlying the diabase, although there may be a few feet of diabase in the river bed. About 500 feet upstream from the site a nearly vertical diabase dike about 3 feet thick, which is probably an offshoot from the sill, crosses the river and has the appearance of a partly destroyed dam.

Because of the occurrence of thin-bedded soft shale directly below the sill, and because the diabase has been nearly. if not entirely eroded away in the channel at the site, it is believed advisable if possible to build the dam 50 feet or more upstream to obtain a thicker diabase foundation. In this way the problem of the shale in the foundation would be overcome, and the dam would be more securely anchored and would be free from seepage through the adjacent rocks. The contact of the sill with the underlying and overlying sediments is tight wherever exposed, hence no leakage should occur along it. The site should be thoroughly drilled to determine the best location for the dam. It is not impossible that the sill thickens eastward, so that a shift of only a few feet would be required for the dam.

A dam 60 feet high would raise the water surface to an altitude of 720 feet and flood 980 acres. By drawing down the water surface 20 feet 14,000 acrefeet of stored water would be obtained. This water could be used through an average head of 53 feet at this site and a total head of 713 feet at all proposed plants if there were no drawdown except at this site. The stored water would generate 500,000 kilowatt-hours of power at the Glide site and $7,000,000$ kilowatt-hours at all proposed sites, if there were no drawdown except at Glide. But the loss of power due to loss of head at this site and the loss of head at lower sites due to drawdown for storage would reduce the net gain, so that in 1926 it would have amounted to $3,500,000$ kilowatt-hours, which is probably a fair estimate of the value of this storage with complete develop. ment of the river. The average loss of head would be 7 feet, and the low flow in an average year with storage in Diamond Lake would amount to about 1,050 second-feet. The average loss of power due to loss of head would be 588 horsepower, which would equal the power obtained from stored water at this site in 51 days. If this site were considered by itself the head should

Diller, J. S., U. S. Geol. Survey Geol. Atlas, Roseburg folio (No. 49), 1898.

$$
47154^{\circ}-30-19
$$


not be drawn down for much over a month at a time, as the loss of power due to loss of head would soon equal the gain due to the stored water. When operated in connection with the other plants on the river it probably would be best to use the stored water during October and November to reduce the period of loss of head.

Summary of potential power at site $12 R B 14$

[Head without drawdown, 60 feet; assumed drawdown, 20 feet; storage capacity, 14,000 acre-feet]

\begin{tabular}{|c|c|c|c|c|}
\hline \multirow[t]{2}{*}{. } & \multicolumn{2}{|c|}{ Flow in second-feet } & \multicolumn{2}{|c|}{ Horsepower } \\
\hline & $\begin{array}{l}90 \text { per } \\
\text { cent of } \\
\text { time }\end{array}$ & $\begin{array}{l}50 \text { per } \\
\text { cent of } \\
\text { time }\end{array}$ & $\begin{array}{l}90 \text { per } \\
\text { cent of } \\
\text { time }\end{array}$ & $\begin{array}{l}50 \text { per } \\
\text { cent of } \\
\text { time }\end{array}$ \\
\hline $\begin{array}{l}\text { Natural flow } \\
\text { Regulated flow } \\
\text { Regulated flow, } 1926 \mathrm{p}\end{array}$ & $\begin{array}{r}950 \\
1,520 \\
1,245\end{array}$ & $\begin{array}{l}2,400 \\
2,300 \\
1,560\end{array}$ & $\begin{array}{l}4,560 \\
7,200 \\
5,980\end{array}$ & $\begin{array}{r}11,500 \\
10,700 \\
6,910\end{array}$ \\
\hline
\end{tabular}

HORSESHOE BEND POWER SITE (12RB 16)

The Horseshoe Bend site is in the NW. 1/4 sec. 17, T. 26 S., R. 4 W., a little below mile 106. A dam 60 feet high is proposed with about half a mile of conduit across the neck of the bend nearly to the point where the 570-foot contour crosses the river, giving a total head of 90 feet. (See pl. 23, A, and fig. 26.)

The maximum recorded peak flow at this site was 90,000 second-feet, on November 23, 1909. With two or three sites developed higher up on the river the peak flow would be ironed out, and provision need be made only for the 24-hour flow.

The dam site is located in a mass of diabase that forms both abutments and crops out in the river bed. This diabase is shown by Diller ${ }^{3}$ to be part of the great intrusive body. About a quarter of a mile upstream from the site outcrops of spheroidal lava were found. These balls of lava have skins 1 to 4 inches thick composed of glass, and they suggest that this lava is a submarine basalt flow. Regardless of the origin of the diabase, it forms an excellent dam site, and although it is minutely jointed only insignificant seepage should occur.

A dam 60 feet high would raise the water surface to an altitude of 660 feet and flood 1,000 acres. A drawdown of 21 feet would make available 16,000 acre-feet of stored water. (See fig. 26.) This water could be used through an average head of 81 feet at the Horseshoe Bend plant and a total head of 651 feet at all plants proposed if there were no drawdown except at this site. The stored water would generate nearly $1,000,000$ kilowatt-hours of power at the Horseshoe Bend site and 7,500,000 kilowatt-hours at all proposed sites, if there were no drawdown at the other sites. But owing to loss of head at this site and sites below, because of drawdown for storage, the net gain from storage in 1926 would have been about 4,000,000 kilowatt-hours. The average loss of head at Horseshoe Bend would be 9 feet, and with an assumed regulated flow of $1,00 \mathrm{C}$ second-feet the loss of power due to loss of head would amount to 720 horsepower. It would require $\mathbf{7 3}$ days for the loss of power due to loss of head to equal the gain at Horseshoe Bend alone due to drawing down the reservoir. If this site were developed independently the storage capacity could be used to equalize the monthly discharge during the summer, and possibly it could be used to advantage during a month of very low flow, especially in October or

\footnotetext{
'Diller, J. S., op. cit.
} 

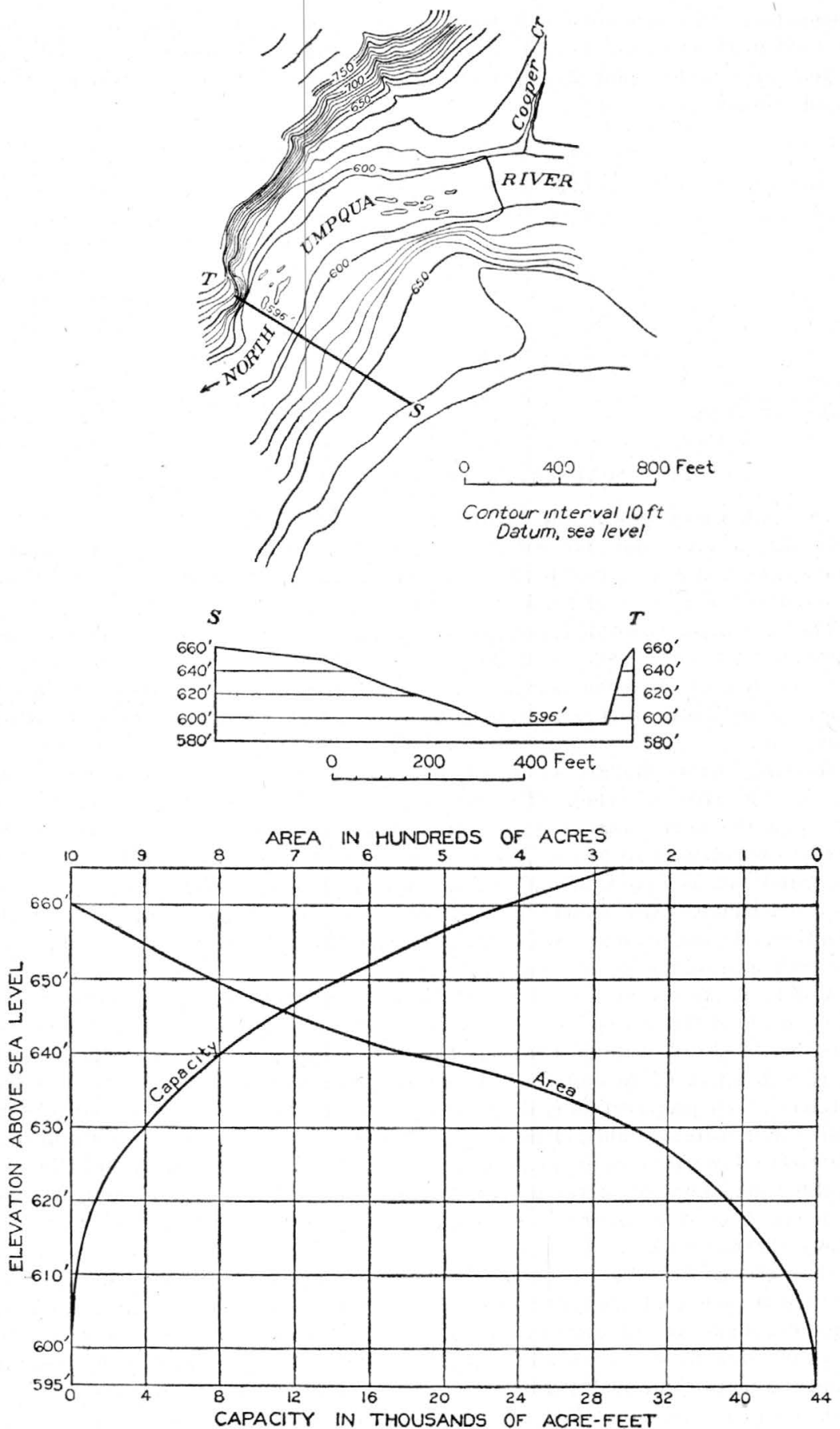

Figure 26.-Plan, cross section, and area and capacity curves, Horseshoe Bend dam site, Umpqua River Basin 
November. In connection with the other sites on the river the storage could be used in October and November, thus limiting the period of loss of head. In a year of very low flow it might be necessary to use the stored water earlier in the summer.

Summary of potential power at site 12RB 15

[Head without drawdown, 90 feet; assumed drawdown, 21 feet; storage capacity, 16,000 acre-feet] -

\begin{tabular}{|c|c|c|c|c|}
\hline \multirow[b]{2}{*}{. } & \multicolumn{2}{|c|}{ Flow in second-feet } & \multicolumn{2}{|c|}{ Horsepower } \\
\hline & $\begin{array}{l}90 \text { per } \\
\text { cent of } \\
\text { time }\end{array}$ & $\begin{array}{l}50 \text { per } \\
\text { cent of } \\
\text { time }\end{array}$ & $\begin{array}{l}90 \text { per } \\
\text { cent of } \\
\text { time }\end{array}$ & $\begin{array}{l}50 \text { per } \\
\text { cent of } \\
\text { time }\end{array}$ \\
\hline $\begin{array}{l}\text { Natural flow } \\
\text { Regulated flow } \\
\text { Regulated flow, } 1926.0\end{array}$ & $\begin{array}{r}950 \\
1,520 \\
1,245\end{array}$ & $\begin{array}{l}2,400 \\
2,400 \\
1,705\end{array}$ & $\begin{array}{r}6,830 \\
10,900 \\
8,950\end{array}$ & $\begin{array}{l}17,300 \\
16,200 \\
10,800\end{array}$ \\
\hline
\end{tabular}

OAK CREEK POWER SITE (12RB 16)

The Oak Creek power site is in the SW. $1 / 4$ sec. 11, T. 26 S., R. 5 W., at mile 97.8, where a dam 65 feet high is proposed. (See pl. 23, B, and fig. 27.) The power house would be built a short distance below the dam at an altitude of $\mathbf{5 0 0}$ feet, giving a total head of $\mathbf{7 0}$ feet.

The maximum recorded peak flow at this site is 90,000 second-feet, on November 23, 1909. The peak flow will be ironed out by dams that will be built farther up the river before this site is developed, and if there are many plants built above this one it may be safe to reduce the spillway capacity somewhat.

Massive, dense diabase of intrusive origin crops out on both abutments and in the river channel. The south side is almost entirely covered with soil, and the north side is composed of weathered diabase, hence at least a 10-foot excavation will be required to reach fresh rock. The diabase is minutely fractured but is amply strong for the proposed dam and not subject to excessive leakage. Any seepage at this site can easily be prevented by a little grouting. If not sealed, however, the cracks will not enlarge by seepage, for the rock is insoluble to percolating water.

A dam 65 feet high would raise the water surface to an altitude of $\mathbf{5 7 0}$ feet and flood 900 acres. A drawdown of 20 feet would make available 14,000 acre-feet of stored water. (See fig. 27.) This water could be used through an average head of 61 feet at the Oak Creek plant and through a total head of 561 feet at all proposed sites if there were no drawdown except at Oak Creek. The stored water would generate over 500,000 kilowatt-hours at this site and $5,500,000$ kilowatt-hours at all proposed sites if there were no drawdown except at this site. Loss of power due to loss of head at this site and loss of head - at lower sites due to drawdown would have reduced the total net gain in 1926 to $3,000,000$ kilowatt-hours, which is probably a fair estimate of the value of this storage when the river is completely developed. The loss of head would average 9 feet, and the low-water flow in an average year with storage in Diamond Lake would amount to about 1,050 second-feet. The average loss of power due to loss of head would be 755 horsepower and this loss would equal the power obtained at this site from the stored water in 46 days.

If the plant were operated independently this storage would be sufficient to equalize the monthly flow during periods of low water and to care for daily load fluctuation. As a part of a system embracing the whole river it probably 

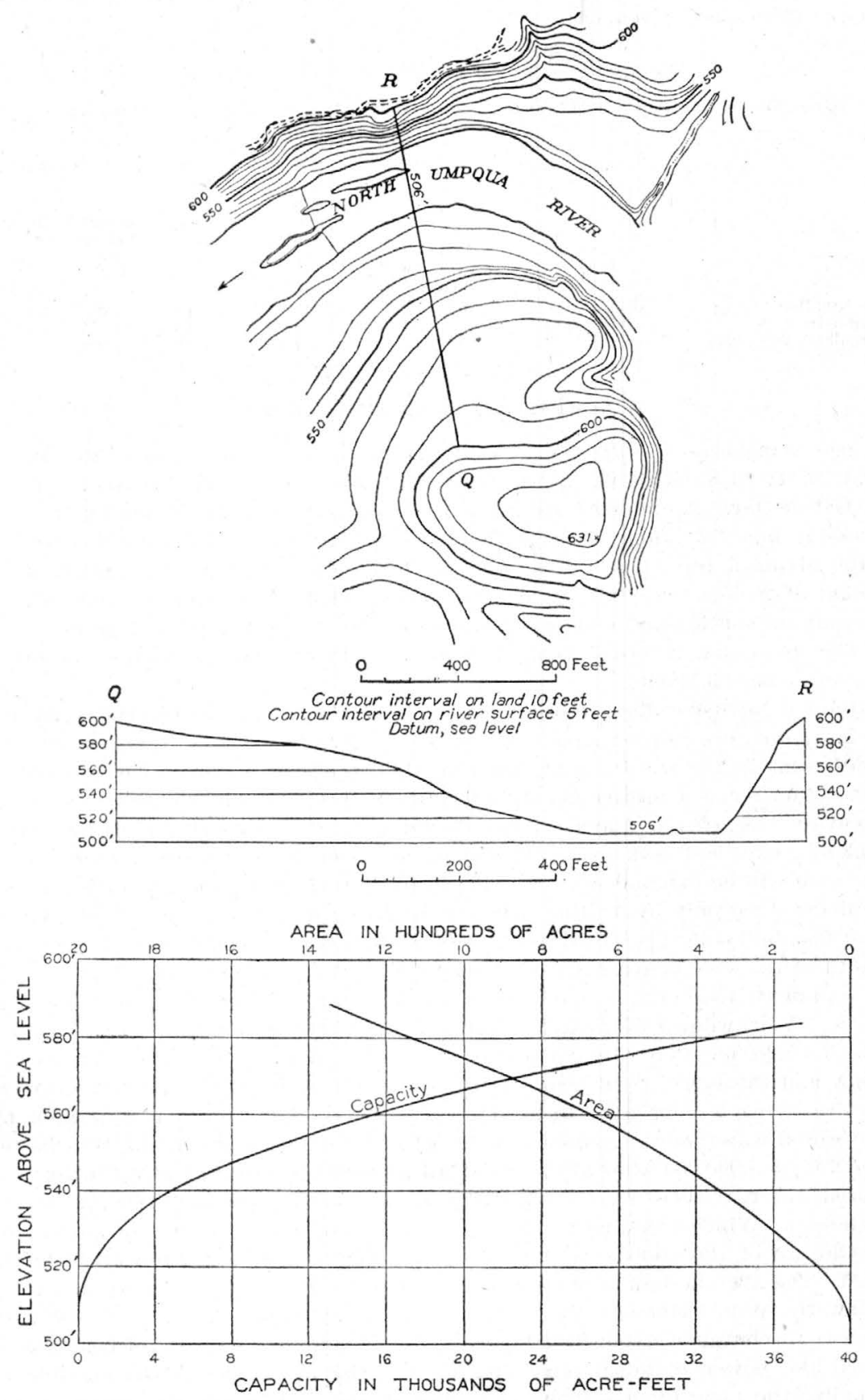

Figure 27.-Plan, cross section, and area and capacity curves, Oak Creek dam site, Umpqua River Basin 
would be best to regard this as storage to be held for emergeney use in a very dry October and November.

Summary of potential power at site $12 R B 16$

[Head without drawdown, 70 feet; assumed drawdown, 20 feet; storage capacity, 14,000 acre-feet]

\begin{tabular}{|c|c|c|c|c|}
\hline & \multicolumn{2}{|c|}{ Flow in second-feet } & \multicolumn{2}{|c|}{ Horsepower } \\
\hline & $\begin{array}{l}90 \text { per } \\
\text { cent of } \\
\text { time }\end{array}$ & $\begin{array}{l}50 \text { per } \\
\text { cent of } \\
\text { time }\end{array}$ & $\begin{array}{l}90 \text { per } \\
\text { cent of } \\
\text { time }\end{array}$ & $\begin{array}{l}50 \text { per } \\
\text { cent of } \\
\text { time }\end{array}$ \\
\hline $\begin{array}{l}\text { Natural flow } \\
\text { Regulated flow, } \\
\text { Regulated flow, } 1926 \text { - }\end{array}$ & $\begin{array}{r}955 \\
1,530 \\
1,250\end{array}$ & $\begin{array}{l}2,410 \\
2,470 \\
1,830\end{array}$ & $\begin{array}{l}5,350 \\
8,570 \\
6,990\end{array}$ & $\begin{array}{r}13,500 \\
12,800 \\
8,630\end{array}$ \\
\hline
\end{tabular}

\section{WINCHESTER POWER SITE (12RB 17)}

The Winchester power site is near the corner common to secs. 19, 20, 29, and 30 , T. 26 S., R. 5 W., about $1 \frac{11}{2}$ miles above the constructed power plant at Winchester. A dam 60 feet high is proposed. (See pl. 24, B, and fig. 28.) A pressure pipe line along the right bank would lead to a point near the present dam, giving a total head of 80 feet, or the present dam could be raised to a height of 20 feet to use the total head available below the proposed dam above, and an automatic plant could be installed at the site of the present plant.

The maximum recorded peak flow at this site, 92,000 second-feet, occurred on November 23, 1909.

Jointed intrusive diabase occurs on the north bank and in the river channel a short distance downstream from the site. This rock also crops out on the south bank at the water's edge, where it disappears under a soil-covered gravel bench that forms a terrace about 20 feet above the river. It will be necessary to excavate the gravel, which is unconsolidated. The underlying diabase will make an excellent rock to key in a dam, and seepage losses under and around the dam will be insignificant: The depth to bedrock under the gravel bench can be determined only by drilling, but it is probably not over 30 feet in any place. The feasibility of this site rests entirely upon economic conditions, because the width of the dam is great and the amount to be excavated is large.

A dam 60 feet high would raise the water level to 500 feet and flood 650 acres. A drawdown of 25 feet would provide 12,000 acre-feet of stored water, which could be used through an average head of 69 feet at the Winchester plant and through a total head of 489 feet at all proposed plants if there were no drawdown except at Winchester. The power that could be generated by the stored water would amount to over 500,000 kilowatt-hours at the Winchester site and to 4,000,000 kilowatt-hours at all proposed plants that could utilize the stored water, if there were no drawdown except at Winchester. Owing to loss of head at Winchester and at the sites lower down, the net gain in power due to the use of the storage would have amounted to 2,000,000 kilowatt-hours in 1926. The average loss of head would be 11 feet. If no plants were constructed below the Winchester site the value of this storage would be limited, for with a mean discharge of 1,000 second-feet the loss of power due to loss of head would equal the power obtained from storage in 38 days. It would be possible to equalize the monthly flow from this storage and to increase the output somewhat in the month of minimum flow. If all plants were developed below this one the power obtained from stored water would be considerably greater than the loss in power due to loss of head, and the total amount of storage could 

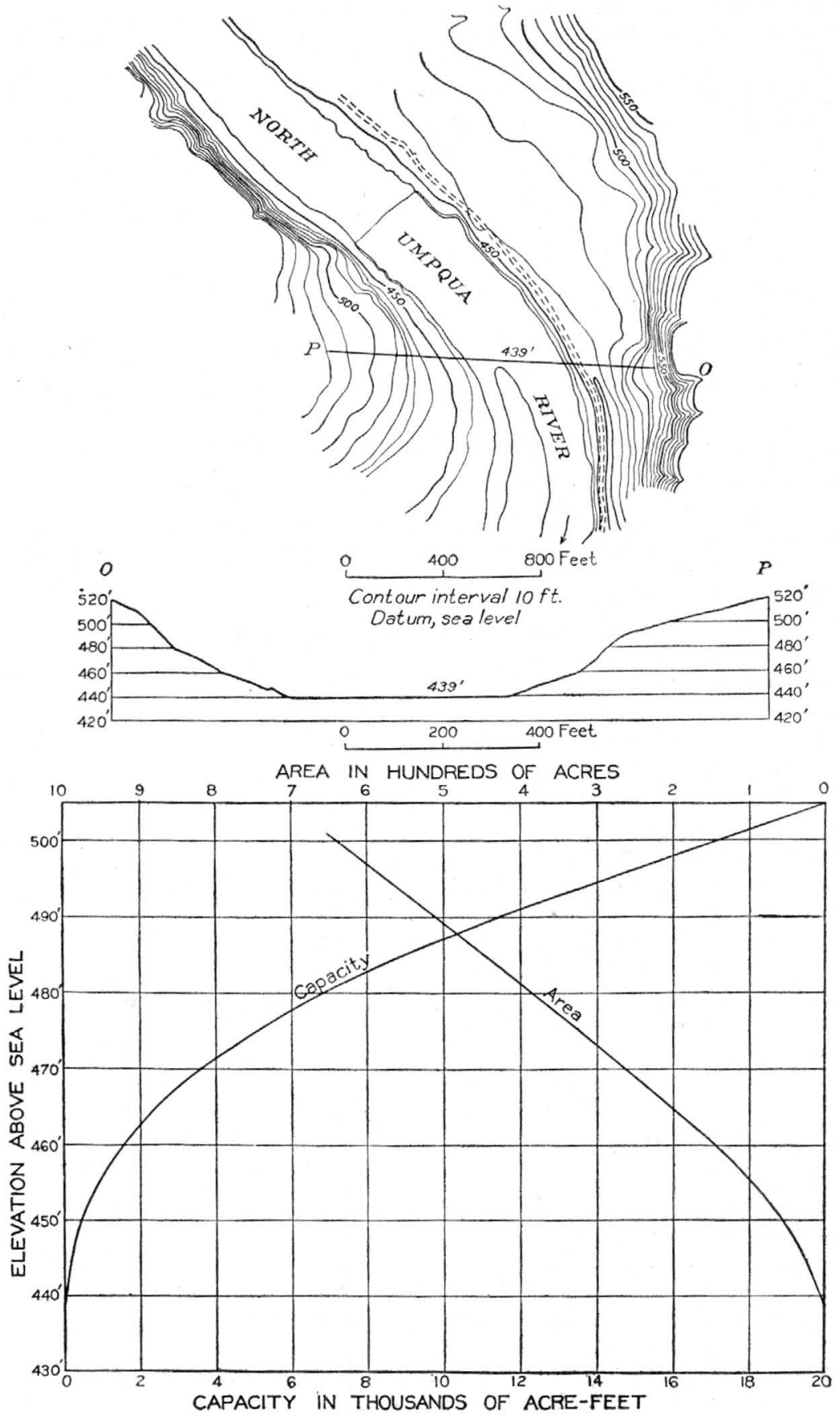

Figurk 28.-Plan, cross section, and area and capacity curves, Winchester dam site, Umpqua River Basin 
be used during the summer at whatever time would give the greatest net increase in power at all the points affected.

Summary of potential power at site $12 R B 17$

[Head without drawdown, 80 feet; assumed drawdown, 25 feet; storage capacity, 12,000 acre-feet.

\begin{tabular}{|c|c|c|c|c|}
\hline & \multicolumn{2}{|c|}{ Flow in second-feet } & \multicolumn{2}{|c|}{ Horsepower } \\
\hline ' & $\begin{array}{l}90 \text { per } \\
\text { cent of } \\
\text { time }\end{array}$ & $\begin{array}{l}50 \text { per } \\
\text { cent of } \\
\text { time }\end{array}$ & $\begin{array}{l}90 \text { per } \\
\text { cent of } \\
\text { time }\end{array}$ & $\begin{array}{l}50 \text { per } \\
\text { cent of } \\
\text { time }\end{array}$ \\
\hline $\begin{array}{l}\text { Natural flow... } \\
\text { Regulated flow } \\
\text { Regulated flow, } 1926.0\end{array}$ & $\begin{array}{r}960 \\
1,520 \\
1,250\end{array}$ & $\begin{array}{l}2,420 \\
2,570 \\
1,950\end{array}$ & $\begin{array}{l}6 ; 140 \\
9,700 \\
7,980\end{array}$ & $\begin{array}{l}15,500 \\
14,900 \\
10,100\end{array}$ \\
\hline
\end{tabular}

PACIFIC HIGHWAY POWER SITE (12RB 18)

The Pacific Highway project is proposed to develop the fall below the Winchester site in case the Wolf Creek or Coles Valley dam is not built to the 400-foot contour. A dam about 5 feet high would be built at the point where the 415 -foot contour crosses the river, in the NW. $1 / 4$ sec. 25 , T. 26 S., R. $6 \mathrm{~W}$. A tunnel a mile long would cross the bend to the little creek on the west side, and a conduit would extend downstream to the point where the 380-foot contour crosses the river, giving a total head of 40 feet. If, as is assumed in this report, a dam is built to flood Coles Valley to the 400 -foot contour, then a fall of 20 feet would be available between the Winchester power house and the backwater from Coles Valley. This head could be developed by a 10-foot dam at the point where the 410-foot contour crosses the river and a mile of open-cut canal. It might be possible to build a 20 -foot dam lower down, but the valley is wide at this point.

The maximum recorded peak flow was 92,000 second-feet. The flow at this site, both natural and regulated, would be the same as at the Winchester site.

Summary of potential power at site 12RB 18

[Head, 20 feet]

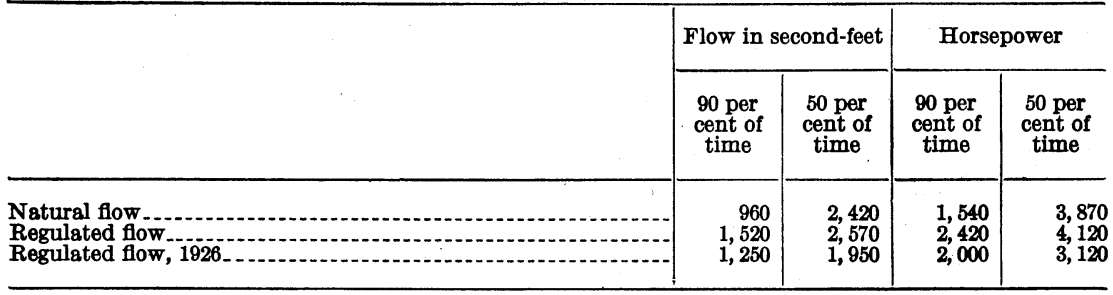

COLES VALIEY POWER SITE (12RB 19)

The Coles Valley site is an alternative dam site to be used in case conditions are not satisfactory at the Wolf Creek site. It is in the N. 1/2 sec. 16, T. $25 \mathrm{~S}$. R. $7 \mathrm{~W}$., at mile 69 . The principal value of this site is for a reservoir, and a dam at either the Wolf Creek or the Coles Valley site could be built to a height sufficient to flood Coles Valley. (See fig. 15.) The Wolf Creek site is believed preferable, and the power and reservoir possibilities are discussed in connection with it. The right abutment at Coles Valley would require considerable 
excavation; otherwise there is no apparent difficulty connected with building a dam at this site. The damages to lands and improvements that would be caused by a reservoir at this point are so great that it may be many years before the demand for power will be sufficient to justify the cost. The capacity of the reservoir would be greater if the dam is built at Wolf Creek. If the reservoir is not built to the full capacity the section of the river in the proposed reservoir site that is not occupied by the reservoir can be developed for power by means of low dams and conduits. A dam 110 feet high is proposed at this site. A reservoir covering 12,000 acres, or most of Coles Valley, would be formed by a dam of this height. Most of the reservoir floor is covered with soil, but exposures here and there indicate that it is underlain by thin-bedded green and black shales and sandstone of the Umpqua formation, all of which are sufficiently impermeable to form a water-tight reservoir. Near the dam site these thin beds give way to massive sandstone.

The left abutment is a cliff of massive light-colored sandstone with a dip of about $10^{\circ}$ upstream. Some of the beds exceed 10 feet in thickness. Sandstone is exposed also all the way across the river channel but disappears on the right abutment under the end of a soil-covered terrace that forms a bench about 20 feet above the river. It will be necessary to drill to determine the exact depth to bedrock at this abutment. Probably at least 15 feet of soil and partly weathered sandstone will have to be removed on this bank to anchor a dam properly. The massive sandstone forms an excellent dam site, and the fact that it dips upstream indicates that seepage through the joints and along the bedding planes will be small. Moreover, the reservoir site appears to be equally impermeable, hence the geology of both the dam site and the reservoir site is favorable to the proposed construction.

Estimates of the power in this section of the river are given on page 292.

\section{WOLF CREEK POWER SITE (12RB 20)}

The Wolf Creek Site is near the east quarter corner of sec. 6, T. 25 S., R. 7 W., at mile 62.8. A dam 145 feet high would raise the water surface to the 400 foot contour and afford a storage capacity of 422,000 acre-feet, with a drawdown of 80 feet. (See fig. 16.) The property damages are discussed under the Coles Valley and Wolf Creek reservoir sites. This dam site is preferable to the Coles Valley site, because of the greater capacity of the reservoir and the increased head at the dam for development of power. If the dam is not built to the full height the head not developed at the dam can be utilized by low dams and conduits. The maximum recorded peak at this site was 172,000 second-feet on February 21, 1927. If the reservoir were built to capacity the peak flow would be ironed out, but the 24-hour flow must be provided for.

Even-bedded, nearly horizontal sound yellow sandstone is exposed all the way across the river channel and up both abutments. The sandstone is sufficiently permeable to allow a small amount of seepage, but this could be prevented by grouting with cement. The foundation and abutments will require practically no excavation; hence this is an unusually fine site in that respect.

If the Wolf Creek Reservoir is built to full capacity the storage provided at sites downstream would not be so valuable, for the regulated flow under these conditions would be around 4,000 second-feet, and that means a loss of 320 horsepower for each foot of loss of head. A draw down of 10 feet for 60 days would mean a loss of 192,000 horsepower-days. It has been assumed that the stored water below Coles Valley would be utilized in November of a very dry year and that a chance would be taken on a rise in December. In an ordinary 
year the stored water at sites below the Coles Valley Reservoir would be reserved until December, and as a rule it would not be used.

Summary of potential power at site $12 R B 20$

[Head without drawdown, 145 feet; assumed drawdown, 80 feet; storage capacity, 422,000 acre-feet]

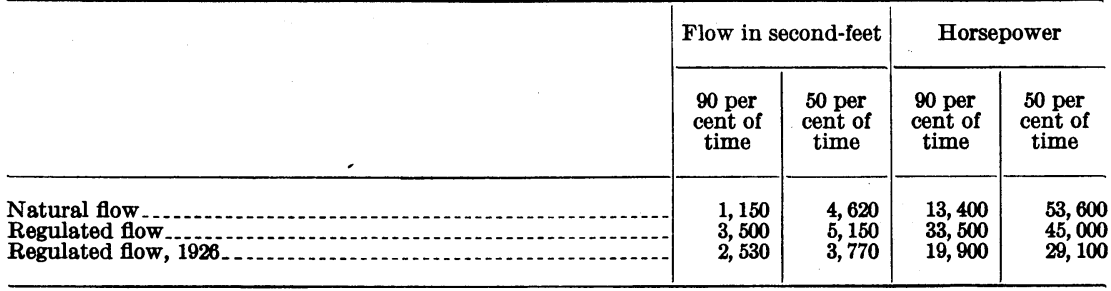

KELLOGG POWER SITE (12RB 21)

The Kellogg power site is in the NE. $1 / 4$ sec. 11, T. 24 S., R. 7 W., at mile 49.5, where it is proposed to build a dam 70 feet high. The conditions for a foundation at the dam site appear to be good, but the section is rather wide. (See pl. 24, $A$, and fig. 29.) The maximum recorded peak flow at this site was 172,000 second-feet on February 21, 1927. It probably would be economical to install machinery to use more than the Q50 flow at this site, in order to carry a large part of the system load in November and December, when water might be available on the lower river and not at the upper sites on the North Umpqua.

The right abutment at the site is formed by massive light-colored sandstone that strikes N. $4^{\circ} \mathrm{W}$. and dips $10^{\circ} \mathrm{W}$. Between some of the massive beds are thin layers of sandstone that contain fossil wood. The strata of sandstone in the river bed are 1 to 3 feet thick but strong and sound. The sandstone crosses the river and disappears under soil on the left abutment. The depth of the soil will have to be determined by test pits, but the rock is doubtless only a few feet below the surface. It is a good site so far as geologic conditions are concerned, although grouting of the bedding planes and joints of the sandstone will probably be necessary to prevent seepage under and around the dam.

A dam 70 feet high would raise the water to an altitude of 255 feet and flood 1,150 acres. A drawdown of 25 feet would provide 21,000 acre-feet of stored water. (See fig. 29.) This water could be used through an average head of 59 feet at the Kellogg site and a total head of 244 feet at all proposed sites if there were no drawdown except at Kellogg. The power that could be generated by the stored water at the Kellogg site would amount to nearly 1,000,000 kilowatt-hours, and at all proposed sites to 3,500,000 kilowatt-hours if there were no drawdown below Kellogg.

If the Wolf Creek reservior site were developed it probably would not be profitable to draw down the head at this site until late in the season, after all water had been used in the reservoir, and usually it would not be drawn down at all. In a very dry year it could probably be drawn down to advantage in November or December. With an assumed mean regulated flow of 1,500 second-feet at low water without the Wolf Creek or Coles Valley Reservoir, the loss of power due to loss of head would amount to 1,320 horsepower a day and would equal the power obtained at this site from the stored water in $3 \mathrm{~s}$ days. If all sites below were developed the flow for the four low-water months could be regulated to give a uniform power output, and the total power could 

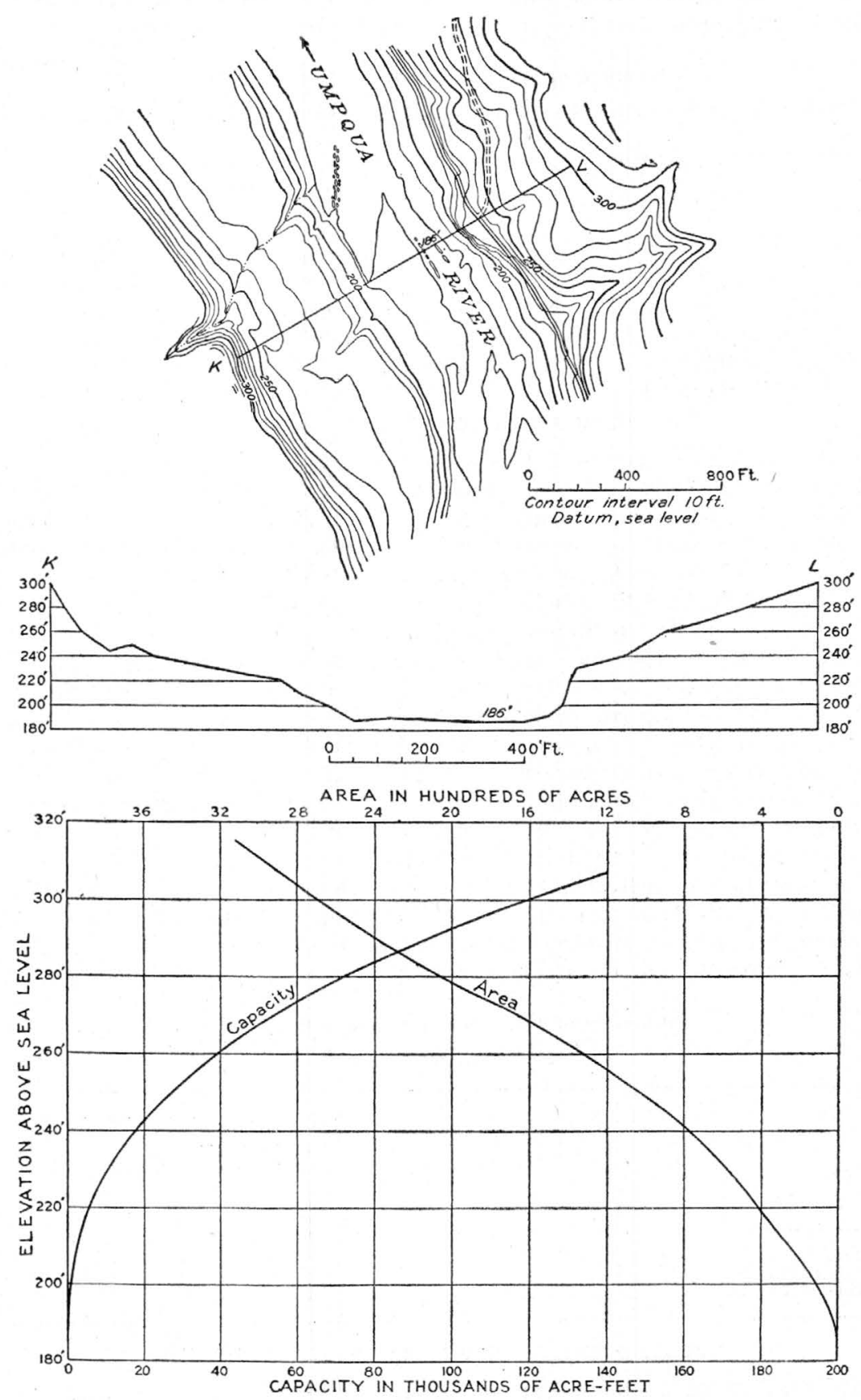

FIgURE 29.-Plan, cross section, and area and capacity curves, Kellogg dam site, Umpqua River Basin 
be increased 750,000 kilowatt-hours if the drawdown covered a period of 123 days and the mean flow entering the reservoir was 1,500 second-feet.

Summary of potential power at site 12RB 21

[Head without drawdown, 70 feet; assumed drawdown, 25 feet; storage capacity, , 21,000 acre-feet ]

\begin{tabular}{|c|c|c|c|c|}
\hline & \multicolumn{2}{|c|}{ Flow in second-feet } & \multicolumn{2}{|c|}{ Horsepower } \\
\hline & $\begin{array}{l}90 \text { per } \\
\text { cent of } \\
\text { time }\end{array}$ & $\begin{array}{l}50 \text { per } \\
\text { cent of } \\
\text { time }\end{array}$ & $\begin{array}{l}90 \text { per } \\
\text { cent of } \\
\text { time }\end{array}$ & $\begin{array}{l}50 \text { per } \\
\text { cent of } \\
\text { time }\end{array}$ \\
\hline $\begin{array}{l}\text { Natural flow } \\
\text { Regulated flow } \\
\text { Regulated flow, } 1926\end{array}$ & $\begin{array}{l}1,150 \\
3,500 \\
2,530\end{array}$ & $\begin{array}{l}4,620 \\
4,910 \\
3,770\end{array}$ & $\begin{array}{r}6,440 \\
19,600 \\
14,200\end{array}$ & $\begin{array}{l}25,900 \\
25,800 \\
19,500\end{array}$ \\
\hline
\end{tabular}

SMITH FERRY POWER SITE (12RB 22)

The dam site for the Smith Ferry project is in the SE. $1 / 4$, sec. 30, T. 23 S., R. $7 \mathrm{~W}$., at mile 44.6. (See fig. 30.) A dam to raise the water level 20 feet would be required to back water to the Kellogg site. A dam of that height would be 1,100 feet long. A canal about $3 \frac{1}{2}$ miles in length and three-fourths of a mile of tunnel would carry the water to the power-house site in the SE. $1 / 4$, sec. 12, T. 23 S., R. 8 W., where a head of 94 feet would be obtained. This is an alternative project to Kelley's Smith Ferry site, and that site is preferable because of the storage which can be obtained and because the cost of the high dam would probably be less than that of the low dam and conduit combined. The flood flow at this site would not greatly exceed that at the gaging station above Elkton, where the maximum recorded peak flow is 172,000 second-feet.

A ledge of massive sandstone is exposed on the right abutment at the dam site above a narrow alluvial bench, which can easily be excavated with a steam shovel. A few outcrops of rock occur in the river bed, but the left abutment is covered with soil. The steep slope of this abutment suggests that the sandstone underlies the soil at a shallow depth. The sandstone strikes N. $22^{\circ} \mathbf{E}$. and dips $5^{\circ}$ E. This dam site is not so desirable as most of those on the Umpqua, because very little rock is exposed as compared to the others, yet it is a perfectly feasible site for a dam, and the rock exposed is solid and strong.

Summary of potential power at site $12 R B 22$

[Head, 94 feet]

\begin{tabular}{|c|c|c|c|c|}
\hline \multirow[b]{2}{*}{ V } & \multicolumn{2}{|c|}{ Flow in second-feet } & \multicolumn{2}{|c|}{ Horsepower } \\
\hline & $\begin{array}{l}90 \text { per } \\
\text { cent of } \\
\text { time }\end{array}$ & $\begin{array}{l}50 \text { per } \\
\text { cent of } \\
\text { time }\end{array}$ & $\begin{array}{l}90 \text { per } \\
\text { cent of } \\
\text { time }\end{array}$ & $\begin{array}{l}50 \text { per } \\
\text { cent of } \\
\text { time }\end{array}$ \\
\hline $\begin{array}{l}\text { Natural flow } \\
\text { Regulated flow, } \\
\text { Regulated flow, } 1926\end{array}$ & $\begin{array}{l}1,150 \\
3,500 \\
2,530\end{array}$ & $\begin{array}{l}4,620 \\
4,910 \\
3,770\end{array}$ & $\begin{array}{r}8,640 \\
26,300 \\
19,000\end{array}$ & $\begin{array}{l}34,700 \\
36,900 \\
28,400\end{array}$ \\
\hline
\end{tabular}

\section{KELIEY'S SMITH FERRY POWER SITE (12RB 23)}

The best site on the lower Umpqua River is in the SE. $1 / 4$ sec. 5 and NE. $1 / 4$ sec. 8, T. 23 S., R. 7 W., at mile 29.5, half a mile above Smith Ferry, and is called Kelley's Smith Ferry site. A masonry dam 85 feet high is proposed at this site. (See pl. 25, $A$, and fig. 31.) The flood discharge there would not 


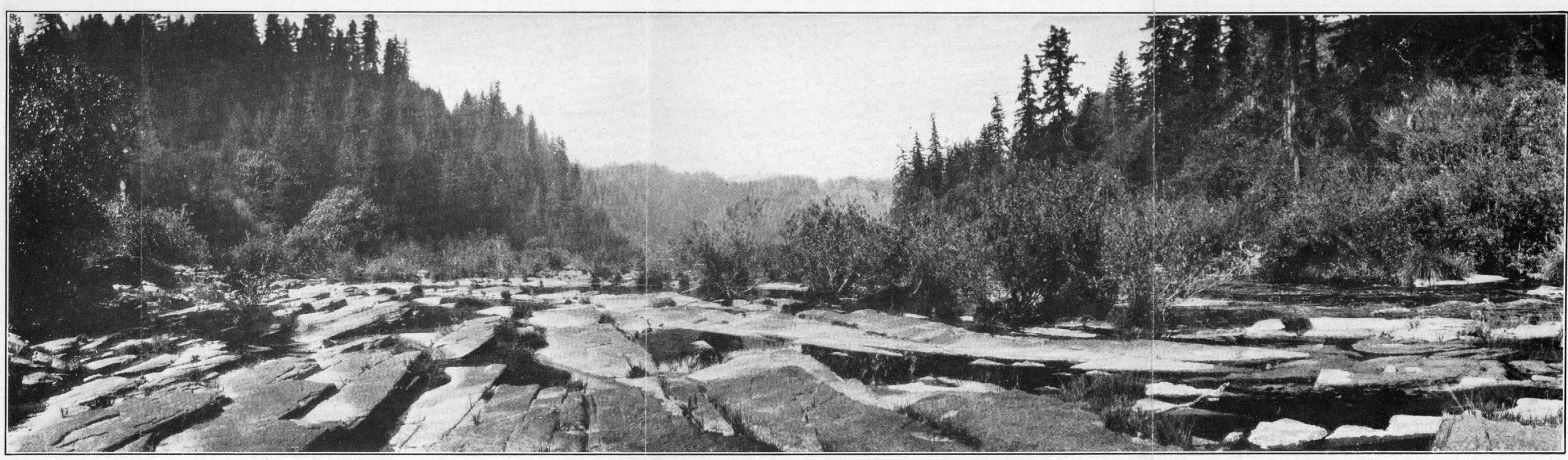

4. BED OF STREAM AT KELLEY'S SMITH FERRY DAM SITE, UMPQUA RIVER BASIN

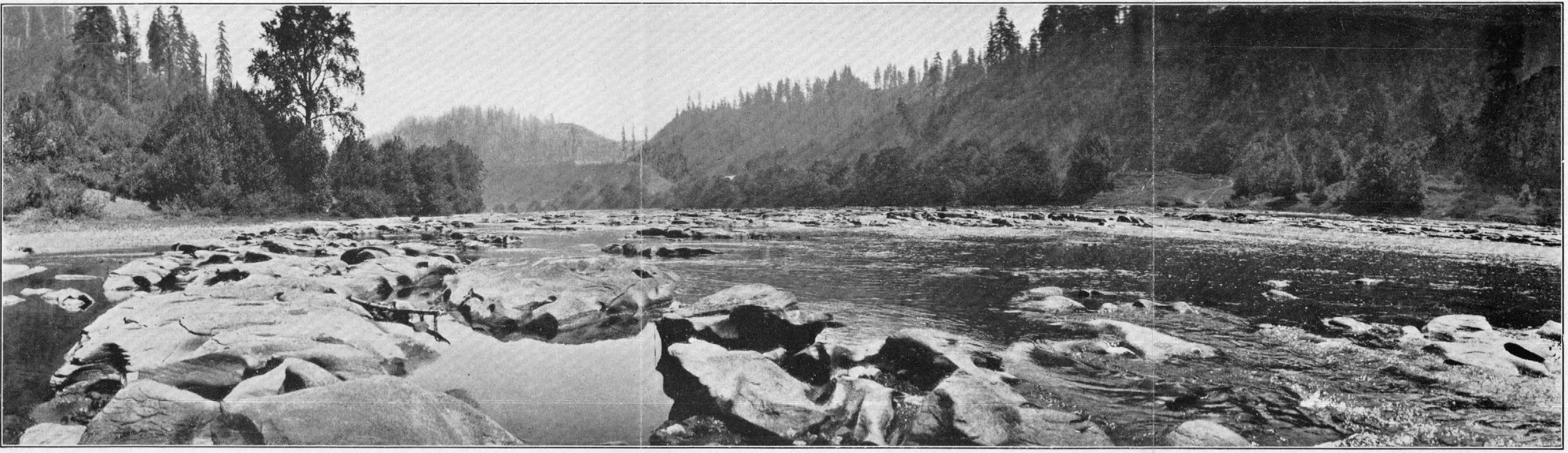

B. SCOTTSBURG LOWER DAM SITE, UMPQUA RIVER BASIN 
greatly exceed the flow at the gaging station above Elkton, where the maximum recorded peak flow was 172,000 second-feet, on February 21, 1927.

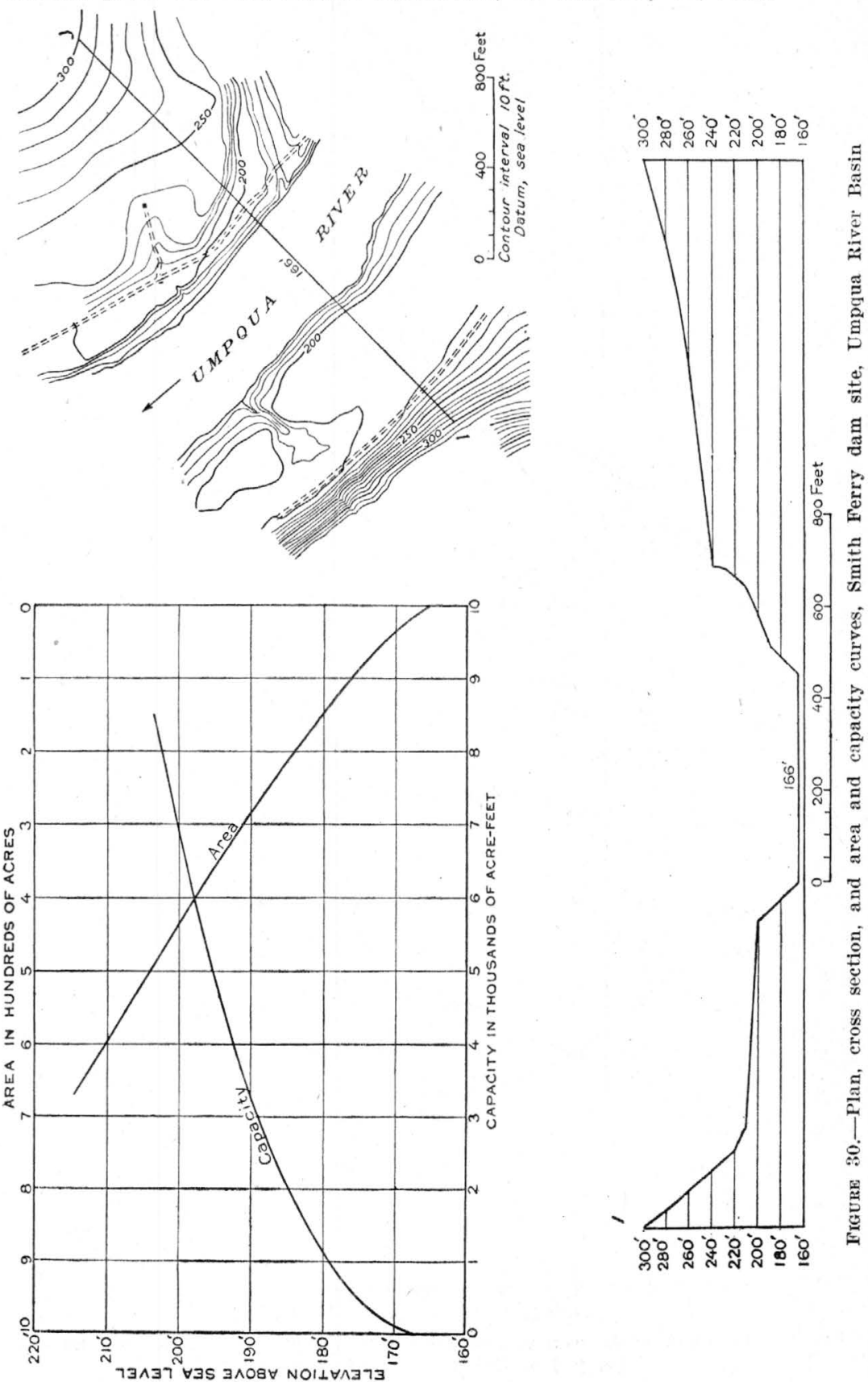

The proposed dam will be keyed into Eocene sandstone. Thin and thick bedded yellow sandstone crops out continuously in the river channel and ex- 

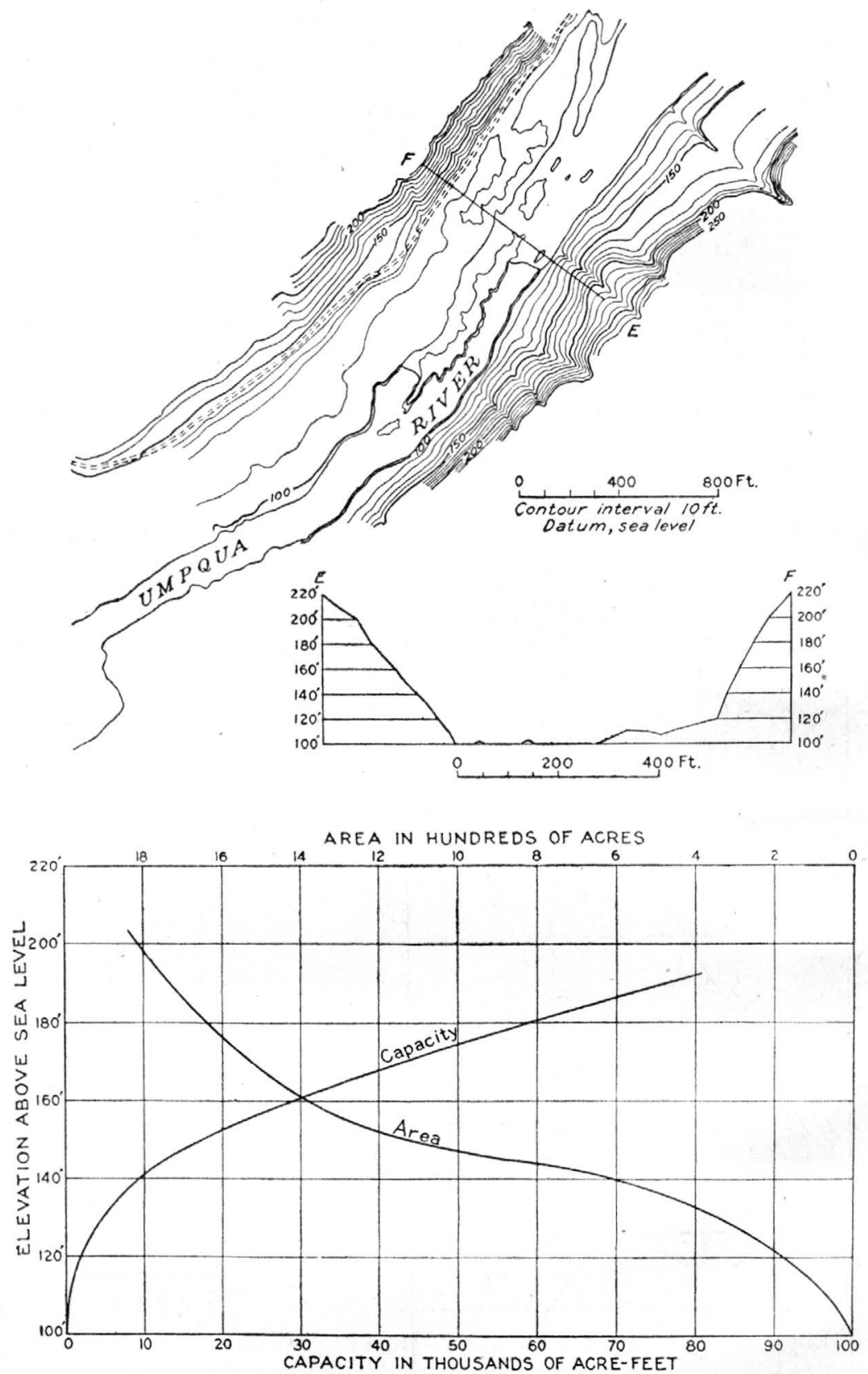

Figure 31.--Plan, cross section, and area and capacity curves, Kelley's Smith Ferry dam site, Umpqua River Basin 
tends half a mile up and downstream from the site, forming a solid rock bed for the river. The sandstone strikes N. $22^{\circ}$ E. and dips $10^{\circ} \mathrm{NW}$. Both abutments consist of the same material and have only small patches of soil covering. As the dip is downstream there will be slight seepage under and around the dam unless the seams are grouted. Nevertheless, this is a magnificent site for a dam and is superior to any of the others on the river.

A dam 85 feet high would raise the water surface to an altitude of 185 feet and flood 1,700 acres. A drawdown of 45 feet would provide 58,000 acrefeet of storage. (See fig. 31.) This amount of stored water could be used through an average head of 65 feet at Kelley's power site and through a total head of $\mathbf{1 6 5}$ feet at this site, Sawyer Rapids, and Scottsburg if there were no drawdown at the lowęr sites. The stored water would generate nearly 3,000,000 kilowatt-hours at this site and 7,500,000 kilowatt-hours at this site and the two others below. If the Wolf Creek Reservoir were developed to full capacity the Kelley's Smith Ferry Reservoir would not be drawn down until the upper reservoir was empty and would remain drawn down ordinarily only one or two months. The net gain from the storage would probably be from $2,000,000$ to 4,000,000 kilowatt-hours. The average loss of head due to drawdown would be 20 feet, and with an assumed minimum flow due to storage above of 1,500 second-feet, if the Wolf Creek Reservoir were not built to full capacity, the loss of power due to loss of head would be 2,400 horsepower a day. In 64 days this loss would equal the power obtained from storage at Kelley's Smith Ferry site. But if all three sites at which the stored water could be used were developed, the net gain, due to drawing down the reservoir, would amount to about 2,000,000 kilowatt-hours, if the period of drawdown lasted not more than four months.

If this unit is considered by itself the stored water could be used in months of very low flow and to equalize the monthly flows. In a year like 1926 it could be used to advantage in July, August, and September. But with considerable storage at sites farther up, especially if the Coles Valley Reservoir were constructed, the storage at this site could be used to advantage only for a month or two, in November and December. In estimating the useful power that could be developed with regulation it is assumed that all sites will have been developed above, including the Wolf Creek Reservoir.

Summary of potential power at site $12 \mathrm{RB} 23$

[Head without drawdown, 85 feet; assumed drawdown, 45 feet; storage capacity, 58,000 acre-feet ]

\begin{tabular}{|c|c|c|c|c|}
\hline & \multicolumn{2}{|c|}{ Flow in second-feet } & \multicolumn{2}{|c|}{ Horsepower } \\
\hline & $\begin{array}{l}90 \text { per } \\
\text { cent of } \\
\text { time }\end{array}$ & $\begin{array}{l}50 \text { per } \\
\text { cent of } \\
\text { time }\end{array}$ & $\begin{array}{l}90 \text { per } \\
\text { cent of } \\
\text { time }\end{array}$ & $\begin{array}{l}50 \text { per } \\
\text { cent of } \\
\text { time }\end{array}$ \\
\hline $\begin{array}{l}\text { Natural flow } \\
\text { Regulated flow } \\
\text { Regulated flow, } 1926 \text {. }\end{array}$ & $\begin{array}{l}1,150 \\
3,500 \\
2,530\end{array}$ & $\begin{array}{l}4,620 \\
5,950 \\
3,770\end{array}$ & $\begin{array}{r}7,820 \\
23,800 \\
17,200\end{array}$ & $\begin{array}{l}31,400 \\
30,900 \\
21,900\end{array}$ \\
\hline
\end{tabular}

SAWYER RAPIDS POWER SITE (12RB '24)

The Sawyer Rapids site is in sec. 4, T. 22 S., R. 8 W., at mile 11.4, about 1 mile below Paradise Creek. (See fig. 32.) This section is rather wide, and a dam to raise the water level 59 feet would be 2,000 feet long on top. Ample 

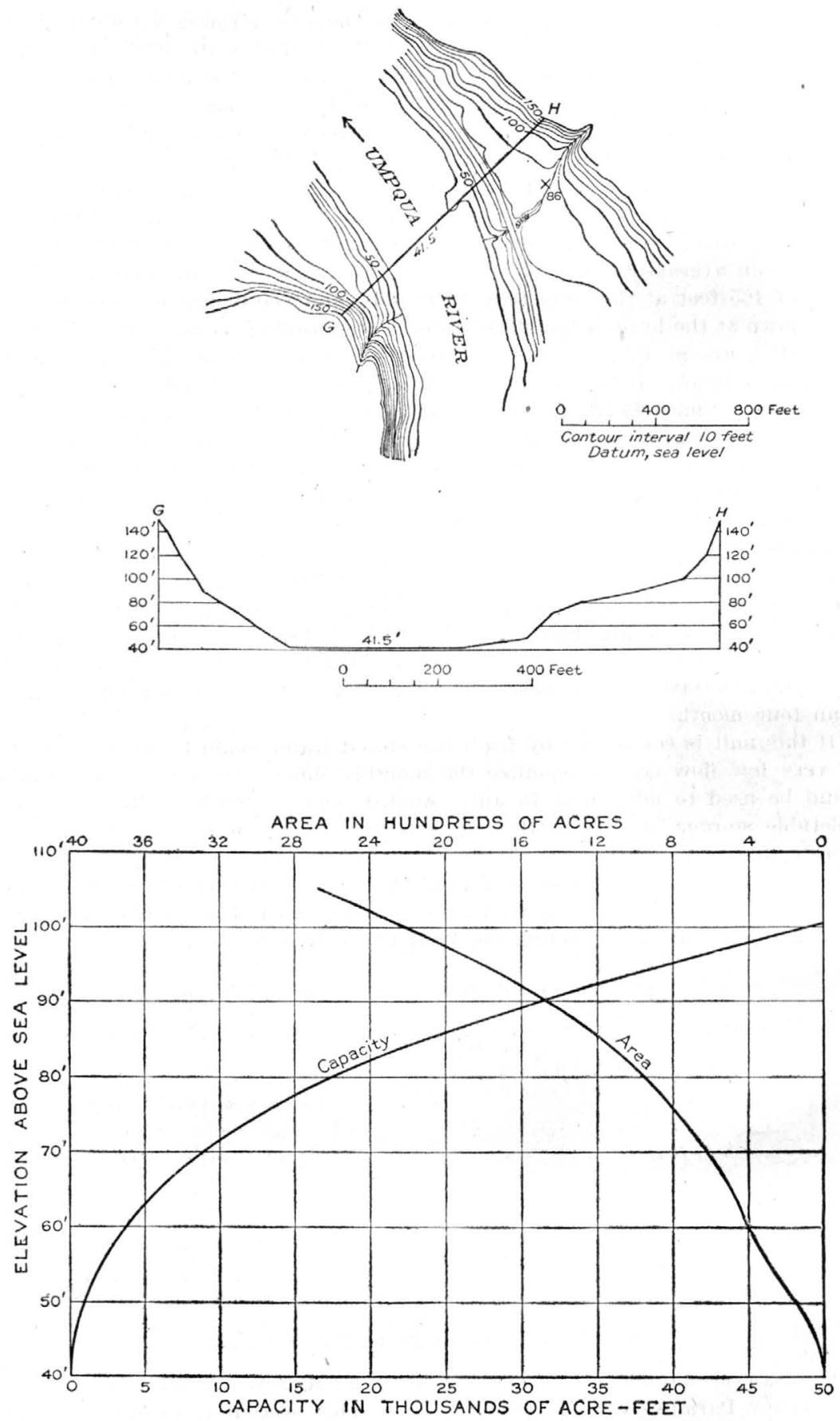

Figure 32.-Plan, cross section, and area and capacity curves, Sawyer Rapids dam site, Umpqua River Basin 
spillway capacity could be provided for the flood flow, which at the gaging station above Elkton has reached a maximum recorded peak flow of 172,000 second-feet, to which must be added the flood flow of Elk Creek.

The left abutment of this site consists of massive sandstone. The right abutment is similar, except for a small alluvial terrace at its foot that will have to be excavated. Massive sandstone with a few thin beds forms a reef in the river. The beds strike N. $62^{\circ}$ E. and dip $10^{\circ} \mathrm{SE}$. No difficulty should be experienced with seepage, for the sandstone dips upstream. The geologic conditions are good at this site.

A dam 59 feet high would raise the water surface to an altitude of 100 feet and flood 2,200 acres. A drawdown of 25 feet would provide 36,500 acre-feet of stored water. (See fig. 32.) This water could be used through an average head of 48 feet at Sawyer Rapids and a total head of 89 feet at Sawyer Rapids and Scottsburg.

The power that could be obtained from stored water would amount to more than 1,500,000 kilowatt-hours, if used through the average head of 48 feet at the dam, and to $3,000,000$ kilowatt-hours, if used through a total head of 89 feet at Sawyer Rapids and Scottsburg. If the Wolf Creek Reservoir were developed to full capacity the head at this site would not be drawn down until late in the year, after the reservoir had been emptied, and in ordinary years it would not be drawn down at all. If the Wolf Creek Reservoir were developed only to a small capacity this site would be drawn upon earlier in the season. The loss of power due to loss of 11 feet head, if the mean flow were 1,500 second-feet, would amount to 1,320 horsepower and would equal the power obtained from stored water at this site in about 68 days and at this site and Scottsburg in 125 days. If this head were all developed at Scottsburg the net gain due to drawdown would be $3,500,000$ kilowatt-hours, even if spread over a period of four months and with a mean flow without storage of 1,500 second-feet. A single dam at Scottsburg would overflow an area 2,300 acres greater than that overflowed by the two dams, so that detailed estimates of cost and of the value of the power from the stored water would be necessary to determine which would be the more feasible scheme. In this report it is assumed that the Scottsburg dam will be built to an altitude of 100 feet, drowning out the Sawyer Rapids site. This will increase the storage available, allow the installation of larger units, and necessitate the building and operation of only one plant. The disadvantage lies in the additional land overflowed.

The following estimates of regulated flow and potential power with regulation are based on the assumption that all sites on the river above have been developed and that the head at Sawyer Rapids is not drawn down for storage.

\section{Summary of potential power at site $12 R B 24$}

[Head, 59 feet]

\begin{tabular}{|c|c|c|c|c|}
\hline \multirow[t]{2}{*}{$*$} & \multicolumn{2}{|c|}{ Flow in second-feet } & \multicolumn{2}{|c|}{ Horsepower } \\
\hline & $\begin{array}{l}90 \text { per } \\
\text { cent of } \\
\text { time }\end{array}$ & $\begin{array}{l}50 \text { per } \\
\text { cent of } \\
\text { time }\end{array}$ & $\begin{array}{l}90 \text { per } \\
\text { cent of } \\
\text { time }\end{array}$ & $\begin{array}{l}50 \text { per } \\
\text { cent of } \\
\text { time }\end{array}$ \\
\hline $\begin{array}{l}\text { Natural flow } \\
\text { Regulated flow } \\
\text { Regulated flow, } 1926\end{array}$ & $\begin{array}{l}1,160 \\
3,500 \\
2,530\end{array}$ & $\begin{array}{l}4,750 \\
5,950 \\
3,770\end{array}$ & $\begin{array}{r}5,480 \\
16,500 \\
11,900\end{array}$ & $\begin{array}{l}22,400 \\
28,100 \\
17,800\end{array}$ \\
\hline
\end{tabular}




\section{SCOTTSBURG POWER SITE (12RB 25)}

Near Scottsburg, just above tidewater, there are two possible sites for a dam about a mile apart. The lower site is in the SE. 1/4 sec. 18, T. 22 S., R. 9 W., at mile 0.9, just above the limits of Scottsburg. (See pl. 25, B, and figs. 33 and 34.) Rock is exposed across the bed of the stream a few feet below the surface and in both abutments. The dam required would be about 600 feet longer at this site than at the upper site, but conditions for the foundation appear so much better at this site that it probably would be preferred. The upper site is in the SE. $1 / 4$ sec. 7 , T. 22 S., R. 9 W., at mile 1.9 . There is about 6 feet of fall in the river between the two sites. A dam to raise the water level to 100 feet is proposed.

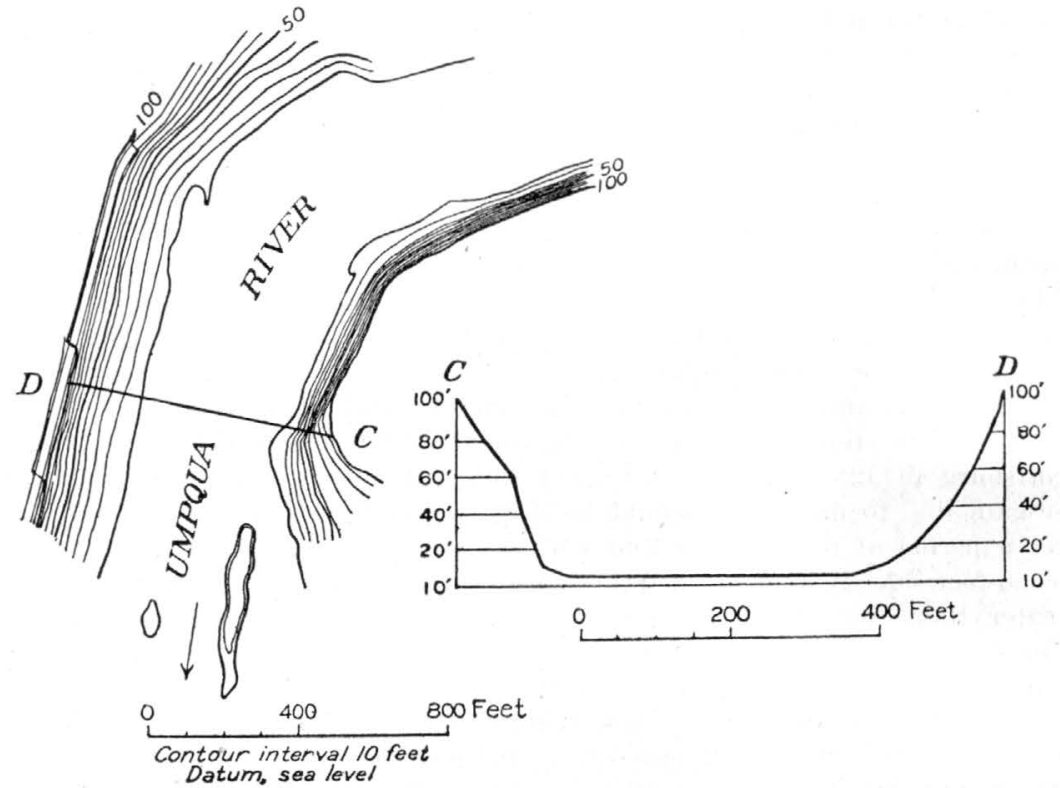

Figurn 33.-Plan and cross section, Scottsburg upper dam site, Umpqua River Basin

The flood flow at this site is probably considerably greater than at the gaging station above Elkton, where the maximum recorded peak flow was 172,000 second-feet, on February 21, 1927.

At the upper site thin-bedded sandstone crops out halfway across the river channel, where the river flows down the strike of the beds. The left or east bank appears to be a marine terrace formed on shale. No rock is exposed in the entire abutment. Sandstone is exposed in the right bank for about 20 feet above the water surface. Above this sandstone is landslide material, consisting of soil inclosing blocks of weathered black shale. This abutment could probably be excavated to the sandstone with little expense. The sandstone at the river's edge at the site strikes N. $12^{\circ}$ E. and dips $14^{\circ}$ SE. It is believed that the black shale above the sandstone on the right abutment has a dip sufficiently steep to bring it under the terrace on the left abutment. If so, the left side of the dam would have to be tied into soft shale. It is advisable to drill a hole in 

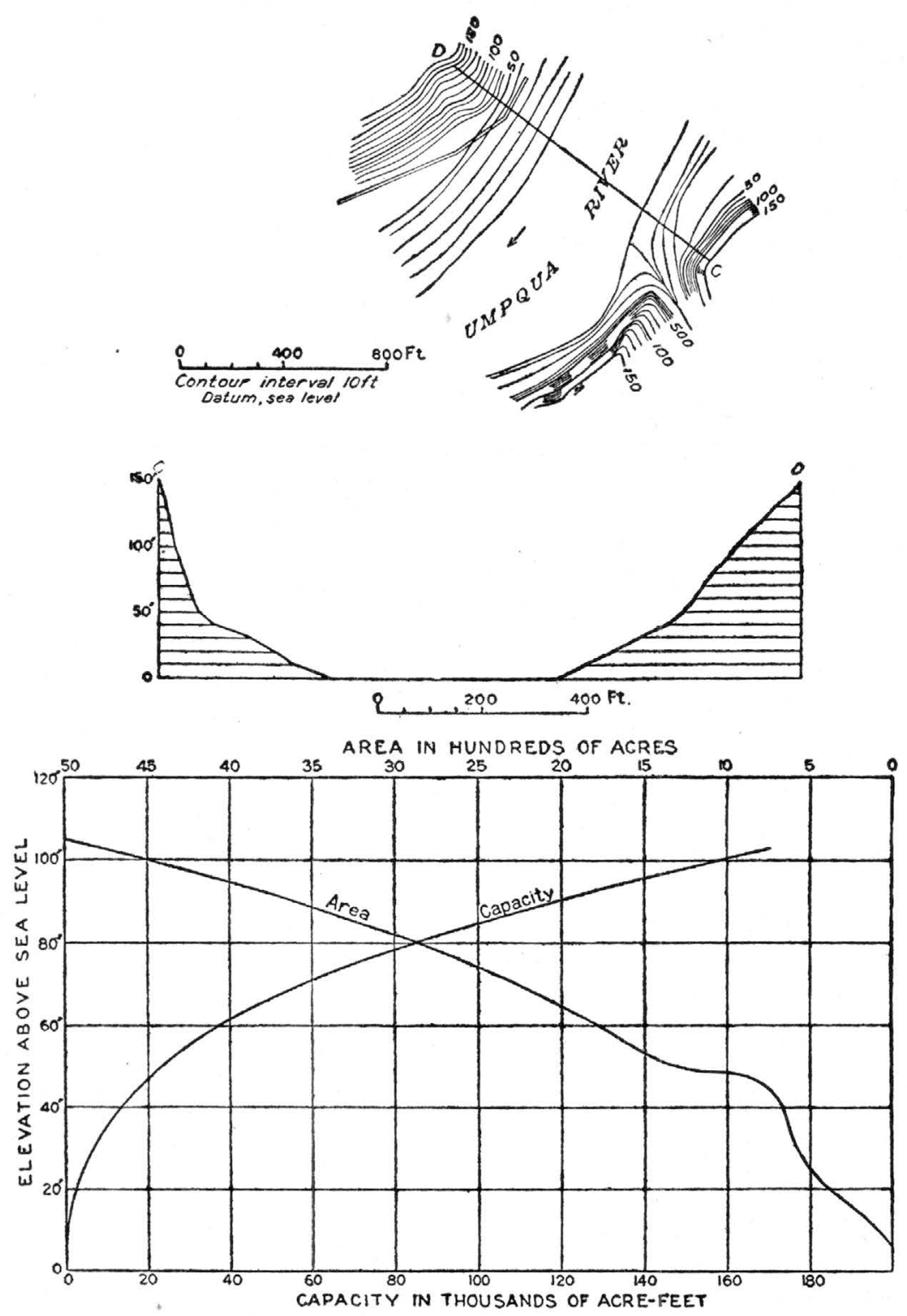

FIGURE 34,-Plan, cross section, and area and capacity curves, Scottsburg lower dam site, Umpqua River Basin 
the left abutment to determine the character of the material in the bench. If it is found to be solid sandstone, and not soft shale, this site will be better than the lower site because it has a narrower section.

At the lower site massive sandstone crops out on the left bank and in the river. The right bank has a small, narrow alluvial bench and a soil-covered slope. Massive sandstone similar to that which occurs in the left abutment lies at shallow depths. The sandstone on the left bank strikes $\mathrm{N}$. $37^{\circ} \mathrm{E}$. and dips $13^{\circ} \mathrm{SE}$. The section is wide at the site but is satisfactory for the proposed 100-foot dam. Because springs are rare in this region it is believed that the sandstone and shale along the Umpqua are poor water bearers and hence not likely to cause leakage from impounded water. Geologically this dam site is preferable to the Scottsburg upper dam site.

The amount of storage available at this site depends on whether the Sawyer Rapids site is developed or all the head is utilized at Scottsburg. If a dam is built at the Sawyer Rapids site then the dam at Scottsburg would be limited to an altitude of $\mathbf{4 1}$ feet above sea level. At this altitude the area of the reservoir would be 650 acres, and the total storage would amount to 15,000 acre-feet. It probably would not pay to draw down the reservoir for this small amount of storage, except in an emergency. But a dam could be built at Scottsburg to an altitude of $\mathbf{1 0 0}$ feet, thus destroying the Sawyer Rapids site and flooding 4,500 acres. With a dam of this height a drawdown of $\mathbf{4 0}$ feet would provide 120,000 acre-feet of storage. This large storage capacity would be valuable if rhe site were developed as an independent unit. (See figs. 33 and 34.) The stored water could be used through an average head of 84 feet and would generate $\mathbf{7 , 0 0 0 , 0 0 0}$ kilowatt-hours. The net power would be considerably less than this, depending on the length of time the head was drawn down and the mean flow of the stream during the period of drawdown, including stored water released at reservoirs upstream. If the Wolf Creek Reservoir were not constructed the regulated low-water flow at Scottsburg probably would not exceed 1,500 second-feet. The mean loss of head due to a drawdown of 40 feet would be 16 feet, and the loss of power due to loss of head if this drawdown were spread over a period of four months would be $3,000,000$ kilowatt-hours. The net gain due to drawing down the reservoir would be $4,000,000$ kilowatt-hours, or an average of 1,800 horsepower for a period of four months. If the Wolf Creek Reservoir were built the period of drawdown at Scottsburg could be confined to about one month at the end of the low-water season, thus decreasing the loss of power due to loss of head.

Summary of potential power at site 12RB 25

[Head without drawdown, 100 feet; assumed drawdown, 40 feet; storage capacity, 120,000 acre-feet]

\begin{tabular}{|c|c|c|c|c|}
\hline \multirow{2}{*}{. } & \multicolumn{2}{|c|}{ Flow in second-feet } & \multicolumn{2}{|c|}{ Horsepower } \\
\hline & $\begin{array}{l}90 \text { per } \\
\text { cont of } \\
\text { time }\end{array}$ & $\begin{array}{l}50 \text { per } \\
\text { cent of } \\
\text { time }\end{array}$ & $\begin{array}{l}90 \text { per } \\
\text { cent of } \\
\text { time }\end{array}$ & $\begin{array}{l}50 \text { per } \\
\text { cent of } \\
\text { time }\end{array}$ \\
\hline $\begin{array}{l}\text { Natural flow } \\
\text { Regulated flow } \\
\text { Regulated flow, } 1926 .\end{array}$ & $\begin{array}{l}1,160 \\
3,530 \\
2,570\end{array}$ & $\begin{array}{l}4,800 \\
6,210 \\
3,800\end{array}$ & $\begin{array}{r}9,270 \\
23,700 \\
20,500\end{array}$ & $\begin{array}{l}38,400 \\
43,000 \\
30,400\end{array}$ \\
\hline
\end{tabular}




\section{LAKE CREEK BASIN}

\section{GENERAL FEATURES}

Lake Creek extends from Diamond Lake, of which it is the outlet, to the North Umpqua River, a distance of $121 / 2$ miles, with a fall of 1,080 feet, or 86 feet to the mile. Records are not available for the winter flow, but from the summer discharge the Q50 flow is estimated roughly at 45 second-feet and the Q90 flow at 23 secondfeet. If Diamond Lake is used for storage, the creek would be dry most of the year, and the flow would be correspondingly larger during the low-water months. In that case plants on Lake Creek would take the place of a steam stand-by, and it is questionable whether they could generate power as cheaply as steam. As the country on both sides of Lake Creek is covered with volcanic ash any conduit would have to be lined. With $31 / 2$ miles of conduit and $21 / 2$ miles of pressure pipe it would be possible to obtain a head of 1,180 feet between Diamond Lake and Lava Creek. The water would then be used through the Clearwater plant, which would have 200 feet less head than the plants on the North Umpqua River above the Clearwater River. For certain kinds of manufacturing load this might be a good combination. Water could be stored in Diamond Lake at night and over Sunday. Then during an 8-hour working day it could be used through a head of 1,180 feet at the Lava Creek plant and 1,400 feet just below, on the Clearwater River. For the purpose of estimating the potential power of Lake Creek it has been assumed that the power will be developed in three units in order to avoid long pressure-pipe lines. These units have been designated Lake Creek Nos. 1, 2, and 3, beginning at Diamond Lake.

The Skyline Trail, a good dirt road, runs down Lake Creek, and except for a steep climb from Medford to Diamond Lake transportation would not be difficult.

\section{LAKE CREEK NO, 1 POWER SITE (12RB 26)}

The Lake Creek No. 1 site includes that section of Lake Creek extending from the outlet of Diamond Lake to the 4,700-foot contour crossing, a distance of 4 miles, with a fall of 480 feet. A conduit $2 \frac{1}{2}$ miles long would be required along the left bank, and because of volcanic ash soil the conduit would have to be lined. A pressure pipe about a mile long would lead to a power house at mile 8.4. The discharge of Lake Creek does not ordinarily fall below 20 second-feet except perhaps during the winter, and a Q90 flow of 20 second-feet and a Q50 flow of 45 second-feet have been assumed for this site. With a head of 480 feet 768 horsepower could be developed for 90 per cent of the time and 1,730 horsepower for 50 per cent of the time. If Diamond Lake were used as a reservoir, both the $Q 90$ flow and the Q50 flow would be zero, but during three or four months of low natural flow the discharge would be correspondingly 
increased. An estimate of the potential power, with the flow regulated for the plant at Toketee Falls, is given in the following tables:

Potential power at site 12RB 26 with flow regulated for plants on North Umpqua River

\begin{tabular}{|c|c|c|c|c|}
\hline \multirow[b]{2}{*}{ Month } & \multicolumn{2}{|c|}{ Average year } & \multicolumn{2}{|c|}{ Year of very low flow } \\
\hline & $\begin{array}{l}\text { Flow in } \\
\text { second- } \\
\text { feet }\end{array}$ & $\begin{array}{l}\text { Horse- } \\
\text { power }\end{array}$ & $\begin{array}{l}\text { Flow in } \\
\text { second- } \\
\text { feet }\end{array}$ & $\begin{array}{l}\text { Horse- } \\
\text { power }\end{array}$ \\
\hline $\begin{array}{l}\text { June. } \\
\text { July } \\
\text { August } \\
\text { September } \\
\text { October } \\
\text { November }\end{array}$ & $\begin{array}{r}0 \\
39 \\
111 \\
150 \\
175 \\
150\end{array}$ & $\begin{array}{r}0 \\
1,500 \\
4,260 \\
5,760 \\
6,720 \\
5,760\end{array}$ & $\begin{array}{r}15 \\
110 \\
140 \\
142 \\
150\end{array}$ & $\begin{array}{r}576 \\
4,220 \\
5,380 \\
5,460 \\
5,760 \\
\end{array}$ \\
\hline
\end{tabular}

IAKE CREEK NO. 2 POWER SITE (12RB 27)

The conduit for the plant at Lake Creek No. 2 site would divert the water at the 4,700-foot contour and follow the right bank to a point above Thielsen Creek, where a pressure pipe would lead to a power house on Lake Creek at an altitude of about 4,475 feet, at mile 6.1. The conduit would be $2 \frac{1}{2}$ miles long, with 0.8 mile of pressure pipe. The head obtained would be 225 feet. The stream flow would be slightly greater than at the mouth of Diamond Lake, as Sheep Creek could be diverted into the conduit.

The natural Q90 flow is estimated at 22 second-feet and the Q50 flow at 50 second-feet. With a head of 225 feet 396 horsepower could be developed for 90 per cent of the time and 900 horsepower for 50 per cent of the time.

Potential power at site 12RB 27 with flow regulated for plants on North Umpqua River

\begin{tabular}{|c|c|c|c|c|}
\hline \multirow[b]{2}{*}{ Month } & \multicolumn{2}{|c|}{ Average year } & \multicolumn{2}{|c|}{ Year of very low flow } \\
\hline & $\begin{array}{l}\text { Flow in } \\
\text { second- } \\
\text { foet }\end{array}$ & $\begin{array}{l}\text { Horse- } \\
\text { power }\end{array}$ & $\begin{array}{l}\text { Flow in } \\
\text { second- } \\
\text { feet }\end{array}$ & $\begin{array}{l}\text { Horse- } \\
\text { power }\end{array}$ \\
\hline 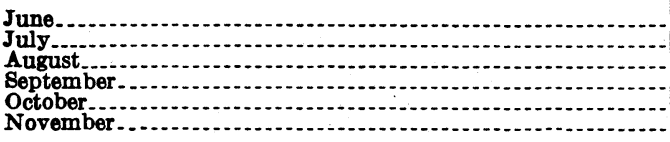 & $\begin{array}{r}0 \\
42 \\
113 \\
152 \\
177 \\
153\end{array}$ & $\begin{array}{r}0 \\
756 \\
2,040 \\
2,740 \\
3,190 \\
2,750\end{array}$ & $\begin{array}{r}17 \\
113 \\
142 \\
144 \\
153 \\
\end{array}$ & $\begin{array}{r}306 \\
2,040 \\
2,560 \\
2,590 \\
2,750\end{array}$ \\
\hline
\end{tabular}

\section{IAKE CREEK NO. 8 POWER SITE (12RB 28)}

The conduit for the Lake Creek No. 3 site would take out just below plant No. 2 at an altitude of 4,475 feet and follow the 4,475-foot contour along the left bank for 3 miles and then pass through three-fourths of a mile of pressure pipe to a power house at an altitude of about 4,150 feet. Thielsen Creek could be diverted into Lake Creek above the headworks and would increase the low flow about 5 second-feet.

The natural Q90 flow is estimated at 27 second-feet and the Q50 flow at 60 second-feet. With a head of 325 feet, 702 horsepower could be developed for 90 per cent of the time, and 1,560 horsepower for 50 per cent of the time. 
Potential power at site $12 \mathrm{RB} 28$ with flow regulated for plants on North Umpqua River

\begin{tabular}{|c|c|c|c|c|c|}
\hline \multirow[b]{2}{*}{ • } & \multirow[b]{2}{*}{ Month } & \multicolumn{2}{|c|}{ Average year } & \multicolumn{2}{|c|}{$\begin{array}{l}\text { Year of very low } \\
\text { flow }\end{array}$} \\
\hline & & $\begin{array}{c}\text { Flow } \\
\text { in second- } \\
\text { feet }\end{array}$ & $\begin{array}{l}\text { Horse- } \\
\text { power }\end{array}$ & $\begin{array}{c}\text { Flow } \\
\text { in second- } \\
\text { feet }\end{array}$ & $\begin{array}{l}\text { Horse- } \\
\text { power }\end{array}$ \\
\hline $\begin{array}{l}\text { June } \\
\text { July } \\
\text { Aug } \\
\text { Sept } \\
\text { Octo } \\
\text { Nov }\end{array}$ & & $\begin{array}{r}10 \\
50 \\
120 \\
160 \\
185 \\
160\end{array}$ & $\begin{array}{r}260 \\
1,300 \\
3,120 \\
4,170 \\
4,820 \\
4,160\end{array}$ & $\begin{array}{r}27 \\
125 \\
165 \\
164 \\
163\end{array}$ & $\begin{array}{r}703 \\
3,250 \\
4,300 \\
4,270 \\
4,240\end{array}$ \\
\hline
\end{tabular}

CLEARWATER RIVER AND FISH CREEK BASINS

The drainage basins of the Clearwater River and Fish Creek are adjacent, and both areas are small, so they probably receive about the same average precipitation, but the low-water flow of the Clearwater River is much larger. This may be due partly to the nature of the soil on the two basins, the Clearwater Basin affording more underground storage, but the principal cause is probably the nature of the underground drainage. The whole county is covered with volcanic ash, through which the precipitation readily sinks until it reaches the old ground surface, and then it follows old drainage channels of whose existence the present topography affords no clue. Both streams have a large amount of fall, but the Clearwater River is more valuable for the development of power, because of its well-sustained flow.

\section{LAVA CREEK POWER SITE (12RB 29)}

The Lava Creek site is an alternative site that would take the place of the three plants on Lake Creek. A conduit would follow the 5,180-foot contour from Diamond Lake for $3 \frac{1}{2}$ miles along the west side and then drop down through $2 \frac{1}{2}$ miles of pressure pipe to the 4,000-foot contour on Lava Creek. Such a development might be desirable if it were decided that because of its scenic or recreational value the Lemolo Falls.site on the North Umpqua River could not be developed. This scheme would make the Diamond Lake water available to the Clearwater River plant. It probably would be found advantageous to divert Bear Creek to this plant, bringing it around on the 5,180-foot contour and using the same pressure pipe. No information on the flow of Bear Creek is available, but it receives about one-third of the run-off from Mount Bailey. It has been assumed in estimating the potential capacity of this site that Bear Creek will be diverted and used at the Lava Creek plant.

The Q90 flow of Bear Creek is estimated at 5 second-feet and the Q50 flow at 15 second-feet, but these figures are probably low. The natural Q90 flow at the Lava Creek site, including Bear Creek water, is estimated at 25 secondfeet and the Q50 flow at 60 second-feet. With a head of 1,180 feet 2,360 horsepower could be developed for 90 per cent of the time and 5,660 horsepower for 50 per cent of the time. 
Potential power at site 12RB 29 with flow regulated for North Umpqua River at Toketee Falls

\begin{tabular}{|c|c|c|c|c|}
\hline \multirow{2}{*}{ Month } & \multicolumn{2}{|c|}{ A verage year } & \multicolumn{2}{|c|}{$\begin{array}{c}\text { Year of very low } \\
\text { flow }\end{array}$} \\
\hline & $\begin{array}{c}\text { Flow } \\
\text { in second- } \\
\text { feet }\end{array}$ & $\begin{array}{l}\text { Horse- } \\
\text { power }\end{array}$ & $\begin{array}{c}\text { Flow } \\
\text { in second- } \\
\text { feet }\end{array}$ & $\begin{array}{l}\text { Horse- } \\
\text { power }\end{array}$ \\
\hline $\begin{array}{l}\text { June- } \\
\text { July } \\
\text { August } \\
\text { September } \\
\text { Oetober- } \\
\text { November }-. .1\end{array}$ & $\begin{array}{r}15 \\
49 \\
116 \\
158 \\
185 \\
165\end{array}$ & $\begin{array}{r}1,410 \\
4,620 \\
10,900 \\
14,900 \\
17,400 \\
15,600\end{array}$ & $\begin{array}{r}30 \\
125 \\
150 \\
165 \\
165\end{array}$ & $\begin{array}{r}2,830 \\
11,800 \\
14,100 \\
15,600 \\
15,600\end{array}$ \\
\hline
\end{tabular}

CLEARWATER RIVER POWER SITE (12RB 30)

The point of diversion for the Clearwater site would be near the mouth of Trap Creek, where the road crosses the Clearwater River. Topography is shown to the 3,700-foot contour on the plan of the Umpqua River, sheet E, but it is probable that the conduit could be built on the 3,800 -foot contour at little additional cost. From the proposed point of diversion to Mowich Creek the construction of an open canal would not be difficult. From Mowich Creek a tunnel less than 3 miles long would lead to a small forebay, from which penstocks $1 \frac{1}{2}$ miles long would drop to the power house. Trap Creek would be diverted into the Clearwater River above the point of diversion. The conduit would be about 6 miles in length, including the 3 miles of tunnel. It is possible to build an open-lined conduit all the way with a few short tunnels, but an open conduit on high hillsides might be difficult to maintain in winter. Construction would not be difficult, but it would be necessary to build 10 miles of road. No good records of the flow of the Clearwater River above Trap Creek are available, but a gaging. station was established there in October, 1927. The following miscellaneous measurements give some idea of the flow:

Miscellaneous discharge measurements of Clearwater River above and below Trap Creek

\begin{tabular}{|c|c|c|}
\hline Date & Location & Discharge \\
\hline $\begin{array}{l}\text { Aug. } 28,1915 \\
\text { Aug. 18, } 1924 \\
\text { Oct. 18, } 1924,19 \\
\text { Aug. 14, } 1925\end{array}$ & $\begin{array}{c}\text { Below Trap Creek } \\
\text { Above Trap Creek }\end{array}$ & $\begin{array}{r}\text { Second-feet } \\
172 \\
113 \\
112 \\
154\end{array}$ \\
\hline
\end{tabular}

These measurements and daily discharge records for October 5 to December 8 and March 24 to September 30, 1928, indicate a Q90 discharge of about 135 second-feet and a Q50 discharge of 185 second-feet in a normal year.

If Diamond Lake were used as a reservoir and the water used to equalize the flow of the North Umpqua River at Toketee Falls, and if the water of Lake Creek and Diamond Lake were diverted to the Clearwater River, the Q90 flow would probably be increased to 165 second-feet, the low period coming before or after the stored water was released. The Q50 flow would remain unchanged. This procedure would increase the value of this site more than is indicated by these figures, however, as the period of low flow and low power 
would then come at a time when the power at other sites was not at a minimum.

This is one of the cheapest sites in the Umpqua River Basin, probably ranking next to the sites at Lemolo Falls and Toketee Falls.

The head assumed in the following estimates is 1,420 feet, which is equivalent to that obtained by diverting the river at the 3,800 -foot contour.

Summary of potential power at site 12RB 30

[Head, 1,420 feet]

\begin{tabular}{|c|c|c|c|c|}
\hline & \multicolumn{2}{|c|}{ Flow in second-feet } & \multicolumn{2}{|c|}{ Horsepower } \\
\hline & $\begin{array}{c}90 \text { per } \\
\text { cent of } \\
\text { time }\end{array}$ & $\begin{array}{l}50 \text { per } \\
\text { cent of } \\
\text { time }\end{array}$ & $\begin{array}{l}90 \text { per } \\
\text { cent of } \\
\text { time }\end{array}$ & $\begin{array}{l}50 \text { per } \\
\text { cent of } \\
\text { time }\end{array}$ \\
\hline $\begin{array}{l}\text { Natural flow- } \\
\text { With storage }\end{array}$ & $\begin{array}{l}135 \\
165\end{array}$ & $\begin{array}{l}185 \\
185\end{array}$ & $\begin{array}{l}15,400 \\
18,800\end{array}$ & $\begin{array}{l}21,000 \\
21,000\end{array}$ \\
\hline
\end{tabular}

FISH CREEK POWER SITE (12RB 31)

The point of diversion for the Fish Creek site would be the 3,100-foot contour where it crosses Fish Creek, just above Slipper Creek. Slipper Creek could be diverted into Fish Creek above the dam. A conduit would then follow the contour across the Fish Creek Desert and down to the Bradley power-house site, which would have a Fish Creek unit. The total head would be 1,060 feet. As the Fish Creek Desert has a surface composed of loose volcanic ash, the 5 miles of conduit would require lining. Only very meager records of the flow of Fish Creek are available. In 1924, a year of extremely low flow, records were obtained at a point just below Camas Creek from June 18 to October 14 . During this period the flow was under 25 second-feet at only one reading. The Q90 flow at the point of diversion is estimated from these records at 28 second-feet and the Q50 flow at 60 second-feet. With a head of 1,060 feet 2,370 horsepower could be developed for 90 per cent of the time and 5,080 horsepower for 50 per cent of the time. No good storage sites are available on this creek.

\section{STEAMBOAT CREEK}

Steamboat Creek drains a comparatively large area, but this area does not have the porous soil that serves as an underground reservoir for the upper North Umpqua River. As a consequence the flow is low for a long period during the summer, and as there are no good reservoir sites on the creek its power value is not great. There is a good dam site at the bend below Singe Creek, but it would not pay to build a high dam because of the low flow. The creek has been divided into three sections for the purpose of estimating its potential power value. None of the sites are attractive, as compared with those on the North Umpqua River, and none will be financially feasible for many years, if ever. The average fall from the mouth of Little Rock Creek to Steamboat ranger station was found by aneroid observation to be 46 feet to the mile. The flow below the mouth of Little Rock Creek was found to be 5 second-feet on July 
13, 1924, and the potential power per mile for this section during low water is less than 20 horsepower. The creek is not considered valuable for power above Johnson Creek.

\section{UPPER STEAMBOAT CREEK POWER SITE (12RB 82)}

The point of diversion for the Upper Steamboat Creek site is near the mouth of Johnson Creek, at an altitude of 1,575 feet. Water would be carried by a conduit along the right bank for about $2 \frac{1}{2}$ miles to a power house at mile 7.3 , where a head of $\mathbf{1 0 0}$ feet could be obtained. The flow at Steamboat Creek ranger station, in sec. 8, T. 25 S., R. 2 E., on July 12, 1924, was 22.2 second-feet, and on the same day the flow at the temporary station above the mouth of Canton Creek was 25.8 second-feet. In 1924 the Q90 flow at this site was about 16 second-feet, but that was an unusually dry year, and ordinarily the Q90 flow would be nearer 20 second-feet. The Q50 flow is roughly estimated at 100 second-feet, which makes a ratio of Q50 to Q90 of 5 to 1, but on the South Umpqua River, which is a somewhat similar stream, the corresponding ratio is 7 to 1 . The estimate of the Q90 flow is believed to be fairly accurate; the estimate of the Q50 flow is little more than a guess but is more likely to be too low than too high. With a head of 100 feet 160 horsepower could be developed for 90 per cent of the time and 800 horsepower for 50 per cent of the time.

\section{STEAMBOAT FALLS POWER SITE (12RB 83)}

A dam 25 feet high is proposed to be built at mile 6.8 on Steamboat Creek, above Steamboat Falls, which would raise the water surface to an altitude of 1,475 feet. About a mile of open conduit and tunnel would carry the water to the mouth of Steelhead Creek, where a head of 105 feet would be obtained. The Q90 flow would be about 21 second-feet, or 1 second-foot greater than that at the upper Steamboat Creek site, and the Q50 flow would be perhaps 105 second-feet, or 5 second-feet greater than at the upper site. With a head of 105 feet $\mathbf{1 7 6}$ horsepower could be developed for 90 per cent of the time and 882 horsepower for 50 per cent of the time. This is the best site on the river, and it does not appear to be very valuable.

\section{LOWER STEAMBOAT CREEK POWER SITE (12RB 34)}

Water for the lower Steamboat Creek site would be diverted from Steamboat Creek at the mouth of Steelhead Creek and carried by tunnel or pipe line to mile 1.7, where the altitude of the tailrace would be 1,180 feet, or just above the backwater from the Boundary power site. The distance is about 4 miles, and the fall is 190 feet. The discharge would be only slightly greater than that at the upper Steamboat Creek power site, 22 second-feet for the Q90 flow and 110 second-feet for the Q50 flow. With a head of 190 feet 334 horsepower could be developed for 90 per cent of the time and 1,670 horsepower for 50 per cent of the time.

\section{ROCK CREEK}

A measurement of Rock Creek at the mouth on September 5, 1924, showed a discharge of 18 second-feet. On September 18 of that year the flow of Steamboat Creek above Canton Creek was 25 secondfeet. The conditions of flow of these creeks are about the same, and the fall of Rock Creek is believed to be about the same as that on Steamboat Creek. During the summer very little power therefore 
is available on Rock Creek. 'For 50 per cent of the time the potential power will probably average 400 horsepower to the mile, but this is secondary power and is not sufficiently valuable to justify development for many years to come.

\section{LITILE RIVER}

The discharge of the Little River at the mouth was 17 secondfeet on September 5, 1924, or 1 second-foot less than that of Rock Creek. The lower end of the Little River was surveyed for $31 / 2$ miles because of possible backwater from the Glide power site, and the fall was found to average about 25 feet to the mile. The Q90 discharge is estimated at 25 second-feet and the Q50 discharge at 200 second-feet. The potential power, therefore, is 50 horsepower to the mile for 90 per cent of the time and 400 horsepower to the mile for 50 per cent of the time. This amount is not sufficient to justify development under present conditions and probably not for many years to come.

\section{SOUTH UMPQUA RIVER}

The South Umpqua River drains an area south of the North Umpqua in which the precipitation is much less than that of the North Umpqua. Its upper basin is rocky, so that there is little underground storage, and the flow in summer drops to a point that precludes power development without storage. Two possible reservoir sites exist on the South Umpqua River, but power obtained through their use would be more expensive than that from the sites on the North Umpqua River, and development is a long way in the future. Some water is pumped from the South Umpqua River to irrigate orchards, but the amount is not great. Water in tributaries is diverted and used for irrigation, reducing the summer flow at the gaging station at Brockway. But the Umpqua Valley is not sufficiently dry to become much of an irrigated section, and the proposed large reservoirs at Days Creek and Perdue probably will not be built for irrigation alone.

\section{FISH LAKE POWER SITE (12RB 85)}

Fish Creek, tributary to the South Umpqua River, heads in Fish Lake, in unsurveyed sec. 6; T. 29 S., R. 3 E. (See pl. 15 and profile of South Umpqua River.) Fish Lake has an area of $\mathbf{1 0 0}$ acres, and it is estimated that a 40 foot dam would furnish sufficient storage to regulate the discharge to a minimum of 15 second-feet. (See Fish Lake reservoir site, p. 251.) Fish Creek has a fall, as determined by aneroid readings, of 1,264 feet in a distance of $4 \frac{1}{2}$ miles. It probably would be necessary to use a pressure pipe as a conduit in utilizing this head. The nearest point to this site on a road is about 20 miles away. This is a fairly good small power site, but it will not be developed for many years because of its remote location. 
Summary of potential power at undeveloped site 12RB 35

[Head, 1,264 feet]

Natural flow

Regulated flow

\begin{tabular}{|c|c|c|c|}
\hline \multicolumn{2}{|c|}{ Flow in second-feet } & \multicolumn{2}{|c|}{ Horsepower } \\
\hline $\begin{array}{l}90 \text { per } \\
\text { cent of } \\
\text { time }\end{array}$ & $\begin{array}{l}50 \text { per } \\
\text { cent of } \\
\text { time }\end{array}$ & $\begin{array}{l}90 \text { per } \\
\text { cent of } \\
\text { time }\end{array}$ & $\begin{array}{l}50 \text { per } \\
\text { cent of } \\
\text { time }\end{array}$ \\
\hline 1.5 & $\begin{array}{l}10 \\
15\end{array}$ & $\begin{array}{r}152 \\
1,520\end{array}$ & $\begin{array}{l}1,010 \\
1,520\end{array}$ \\
\hline
\end{tabular}

BLACK ROOK POWER SITE (12RB 86)

The Black Rock site includes a stretch of the South Umpqua River 11/4 miles long, between the mouths of Fish Creek and Black Rock Creek. (See pl. 15.) The power would probably be developed by a conduit. The total head is 67 feet, and the estimated Q50 flow of 51 second-feet gives a potential power capacity of 273 horsepower. This is 218 horsepower to the mile for 50 per cent of the time without storage. With storage in Fish Lake the potential power for 50 per cent of the time would be 240 horsepower to the mile. So even under the best conditions this site is of little value.

Sumonary of potential power at undevelopeal site $12 R B \quad 36$

[Head, 67 feet]

\begin{tabular}{|c|c|c|c|c|}
\hline & \multicolumn{2}{|c|}{ Flow in second-feet } & \multicolumn{2}{|c|}{ Horsepower } \\
\hline & $\begin{array}{l}90 \text { per } \\
\text { cent of } \\
\text { time }\end{array}$ & $\begin{array}{l}50 \text { per } \\
\text { cent of } \\
\text { time }\end{array}$ & $\begin{array}{l}90 \text { per } \\
\text { cent of } \\
\text { time }\end{array}$ & $\begin{array}{l}50 \text { per } \\
\text { cent of } \\
\text { time }\end{array}$ \\
\hline $\begin{array}{l}\text { Natural flow } \\
\text { Regulated flow }\end{array}$ & $\begin{array}{l}10 \\
23\end{array}$ & $\begin{array}{l}51 \\
56\end{array}$ & $\begin{array}{r}54 \\
123\end{array}$ & $\begin{array}{l}273 \\
300\end{array}$ \\
\hline
\end{tabular}

SOUTH UMPQUA FALIS POWER SITE (12RB 87)

The South Umpqua Falls site embraces a 5-mile stretch of the South Umpqua River, extending from Black Rock Creek to a point below South Umpqua Falls. (See pl. 15.) The falls are only 18 feet in height. The total fall in the stretch of river is $\mathbf{3 4 7}$ feet, as determined by aneroid readings, and this head would be developed by a low diversion dam and conduit. There is a good dam site about a mile above the falls, with bedrock exposed in the center of the river and on both banks, but it would not be feasible to construct a dam to create head on a stream of so much slope and so little flow. The only storage would be that in the Fish Lake Reservoir.

Summary of potential power at undeveloped site 12RB 37

[Head, 347 feet]

\begin{tabular}{|c|c|c|c|c|}
\hline & \multicolumn{2}{|c|}{ Flow in second-feet } & \multicolumn{2}{|c|}{ Horsepower } \\
\hline & $\begin{array}{l}90 \text { per } \\
\text { cent of } \\
\text { time }\end{array}$ & $\begin{array}{l}50 \text { per } \\
\text { cent of } \\
\text { time }\end{array}$ & $\begin{array}{l}90 \text { per } \\
\text { cent of } \\
\text { time }\end{array}$ & $\begin{array}{l}50 \text { per } \\
\text { cent of } \\
\text { time }\end{array}$ \\
\hline $\begin{array}{l}\text { Natural flow } \\
\text { Regulated flow }\end{array}$ & $\underset{33}{20}$ & $\begin{array}{l}104 \\
109\end{array}$ & $\begin{array}{l}556 \\
917\end{array}$ & $\begin{array}{l}2,890 \\
3,020\end{array}$ \\
\hline
\end{tabular}


BOULDER CREEK POWER SITE (12RB 38)

The Boulder Creek site involves a 6-mile stretch of the South Umpqua River, reaching from a point below the falls to Boulder Creek. (See pl. 15.) The total fall, as determined by aneroid barometer, is 195 feet, or 32 feet to the mile. The head available would be developed by conduit. The nearest road is about 8 miles below Boulder Creek, but the road will probably be extended up the South Umpqua River long before the demand for power is sufficient to justify the development of this site.

Summary of potential power at undeveloped site 12RB 38

[Head, 195 feet]

\begin{tabular}{|c|c|c|c|c|}
\hline \multirow[t]{2}{*}{. } & \multicolumn{2}{|c|}{ Flow in second-feet } & \multicolumn{2}{|c|}{ Horsepower } \\
\hline & $\begin{array}{l}90 \text { per } \\
\text { cent of } \\
\text { time }\end{array}$ & $\begin{array}{l}50 \text { per } \\
\text { cent of } \\
\text { time }\end{array}$ & $\begin{array}{l}90 \text { per } \\
\text { cent of } \\
\text { time }\end{array}$ & $\begin{array}{l}50 \text { per } \\
\text { cent of } \\
\text { time }\end{array}$ \\
\hline $\begin{array}{l}\text { Natural flow } \\
\text { Regulated flow }\end{array}$ & $\begin{array}{l}25 \\
35\end{array}$ & $\begin{array}{l}146 \\
150\end{array}$ & $\begin{array}{l}390 \\
546\end{array}$ & $\begin{array}{l}2,280 \\
2,320\end{array}$ \\
\hline
\end{tabular}

DUMONT POWER SITE (12RB 39)

The head of 65 feet at the Dumont site, which includes the South Umpqua River from Boulder Creek to Dumont Creek, could be utilized by means of a dam at a site a quarter of a mile below Dumont Creek. (See pl. 15.) But it would probably be much cheaper to construct 2 miles of pipe line, which would make the same head available. There is a small mine near this site, and the owner said that he planned to develop the power for use in the mine. It probably would be more economical to build about 12 miles of transmission line to reach the line of the California-Oregon Power Co. and buy power from that company. The dam site is fairly good, but the potential power is not sufficient to justify a dam.

Summary of potential power at undeveloped site 12RB 39

[Head, 65 feet]

\begin{tabular}{|c|c|c|c|c|}
\hline & \multicolumn{2}{|c|}{ Flow in second-feet } & \multicolumn{2}{|c|}{ Horsepower } \\
\hline . & $\begin{array}{l}90 \text { per } \\
\text { cent of } \\
\text { time }\end{array}$ & $\begin{array}{l}50 \text { per } \\
\text { cent of } \\
\text { time }\end{array}$ & $\begin{array}{l}90 \text { per } \\
\text { cent of } \\
\text { time }\end{array}$ & $\begin{array}{l}50 \text { per } \\
\text { cent of } \\
\text { time }\end{array}$ \\
\hline $\begin{array}{l}\text { Natural flow } \\
\text { Regulated flow }\end{array}$ & $\begin{array}{l}38 \\
48\end{array}$ & $\begin{array}{r}250 \\
250\end{array}$ & $\begin{array}{l}198 \\
250\end{array}$ & $\begin{array}{l}1,300 \\
1,300\end{array}$ \\
\hline
\end{tabular}

\section{DEADMAN CREEK POWER SITE (12RB 40)}

The Deadman Creek site comprises a stretch of 6 miles of the South Umpqua River from the Dumont dam site to Deadman Creek. (See pl. 15.) The fall is 175 feet, as determined by aneroid barometer. Development would be effected by an open conduit or a pressure pipe line. Like all the other sites on the South Umpqua River, this one offers nothing very attractive. It is reached by road from Tiller. 
Summary of potential power at undeveloped site, 12RB 40

[Head, 175 feet]

\begin{tabular}{|c|c|c|c|c|}
\hline & \multicolumn{2}{|c|}{ Flow in second-feet } & \multicolumn{2}{|c|}{ Horsepower } \\
\hline & $\begin{array}{l}90 \text { per } \\
\text { cent of } \\
\text { time }\end{array}$ & $\begin{array}{l}50 \text { per } \\
\text { cent of } \\
\text { time }\end{array}$ & $\begin{array}{l}90 \text { per } \\
\text { cent of } \\
\text { time }\end{array}$ & $\begin{array}{l}50 \text { per } \\
\text { cent of } \\
\text { time }\end{array}$ \\
\hline $\begin{array}{l}\text { Natural flow } \\
\text { Regulated flow }\end{array}$ & $\begin{array}{l}45 \\
55\end{array}$ & $\begin{array}{l}300 \\
300\end{array}$ & $\begin{array}{l}630 \\
770\end{array}$ & $\begin{array}{l}4,200 \\
4,200\end{array}$ \\
\hline
\end{tabular}

\section{TILIER POWER SITE (12RB 41)}

A low diversion dam at the mouth of the South Fork of the South Umpqua River would back the water up to Deadman Creek. (See pl. 15.) A conduit 5 miles long would reach the mouth of Elk Creek at Tiller, where a head of 160 feet would be obtained. This fall is based on aneroid readings. A gaging station was maintained above Elk Creek near Tiller from November, 1910, to November, 1911. The Q90 flow for this period was 74 second-feet and the Q50 flow 625 second-feet. The corresponding figures at Brockway for that year were 126 and 1,080 second-feet. A 7-year record shows that the Q90 discharge at Brockway is 141 second-feet and the Q50 discharge 1,000 second-feet. The Q90 discharge above Elk Creek has been assumed to be 75 second-feet and the Q50 discharge 600 second-feet. There are good roads leading to Tiller, which is reached by the California-Oregon Power Co.'s transmission lines, but the potential power at this site is not sufficient to justify development for many years.

Summary of potential power at undeveloped site, 12RB 41

[Head, 160 feet]

\begin{tabular}{|c|c|c|c|c|}
\hline \multirow{2}{*}{. } & \multicolumn{2}{|c|}{ Flow in second-feet } & \multicolumn{2}{|c|}{ Horsepower } \\
\hline & $\begin{array}{l}90 \text { per } \\
\text { cent of } \\
\text { time }\end{array}$ & $\begin{array}{l}50 \text { per } \\
\text { cent of } \\
\text { time }\end{array}$ & $\begin{array}{l}90 \text { per } \\
\text { cent of } \\
\text { time }\end{array}$ & $\begin{array}{l}50 \text { per } \\
\text { cent of } \\
\text { time }\end{array}$ \\
\hline $\begin{array}{l}\text { Natural flow } \\
\text { Regulated flow }\end{array}$ & $\begin{array}{r}75 \\
85\end{array}$ & $\begin{array}{l}600 \\
600\end{array}$ & $\begin{array}{r}960 \\
1,090\end{array}$ & $\begin{array}{l}7,680 \\
7,680\end{array}$ \\
\hline
\end{tabular}

\section{COFFEE OREEK POWER SITE (12RB 42)}

The Coffee Creek site is a 3-mile stretch of the South Umpqua River between Tiller and the backwater from Perdue reservoir. (See pl. 15.) The total fall is 80 feet, or less than 27 feet to the mile. The Q50 flow is fairly high for this site, but at present such secondary power is not very valuable, and at low water the potential power is less than 200 horsepower to the mile. The site probably will not be developed until all the secondary power can be used, which will be many years in the future. 
Summary of potential power at undeveloped site $12 R B$

[Head, 80 feet]

\begin{tabular}{|c|c|c|c|c|}
\hline & \multicolumn{2}{|c|}{ Flow in second-feet } & \multicolumn{2}{|c|}{ Horsepower } \\
\hline & $\begin{array}{c}90 \text { per } \\
\text { cent of } \\
\text { time }\end{array}$ & $\begin{array}{l}50 \text { per } \\
\text { cent of } \\
\text { time }\end{array}$ & $\begin{array}{l}90 \text { per } \\
\text { cent of } \\
\text { time }\end{array}$ & $\begin{array}{c}50 \text { per } \\
\text { cent of } \\
\text { time }\end{array}$ \\
\hline $\begin{array}{l}\text { Natural flow } \\
\text { Regulated flow }\end{array}$ & $\begin{array}{l}80 \\
80\end{array}$ & $\begin{array}{l}650 \\
650\end{array}$ & $\begin{array}{l}512 \\
576\end{array}$ & $\begin{array}{l}4,160 \\
4,160\end{array}$ \\
\hline
\end{tabular}

PERDUE POWER SITE (18RB 48)

The Perdue site is a combined reservoir and power site. The dam site, which is just below Perdue post office, reservoir possibilities, and regulated flow are discussed in connection with the Perdue reservoir site. (See p. 252.) The average head with a dam 100 feet high and 80 feet of drawdown is estimated at 65 feet. The head for 90 per cent of the time is estimated at 40 feet and for 50 per cent of the time at 100 feet. The storage would probably be used to give a uniform flow rather than a uniform power output, because of the power sites below. From records for 1911 above Elk Creek, near Tiller, and from seven years of records at Brockway, the regulated Q90 flow is estimated at 250 second-feet with storage. This is a fairly feasible reservoir and power site when considered as auxiliary to the sites on the main Umpqua River.

Summary of potential power at undeveloped site 12RB 43

[Head without drawdown, 100 feet; assumed drawdown, 80 feet; storage capacity, 37,600 acre-feet ]

\begin{tabular}{|c|c|c|c|c|}
\hline \multirow[b]{2}{*}{ 冫 } & \multicolumn{2}{|c|}{ Flow in second-feet } & \multicolumn{2}{|c|}{ Horsepower } \\
\hline & $\begin{array}{l}90 \text { per } \\
\text { cent of } \\
\text { time }\end{array}$ & $\begin{array}{l}50 \text { per } \\
\text { cent of } \\
\text { time }\end{array}$ & $\begin{array}{l}90 \text { per } \\
\text { cent of } \\
\text { time }\end{array}$ & $\begin{array}{l}50 \text { per } \\
\text { cent of } \\
\text { time }\end{array}$ \\
\hline $\begin{array}{l}\text { Natural flow } \\
\text { Regulated flow }\end{array}$ & $\begin{array}{r}85 \\
250\end{array}$ & $\begin{array}{l}700 \\
700\end{array}$ & $\begin{array}{r}680 \\
.800\end{array}$ & $\begin{array}{l}5,600 \\
5,600\end{array}$ \\
\hline
\end{tabular}

a Estimated head 40 feet.

\section{DAYS CREEK POWER BITE (18RB 44)}

The Days Creek site is a combined reservoir and power site. The dam site, which is $1 \frac{1}{2}$ miles above the mouth of the creek, the plan of storage, and the regulated flow are discussed in connection with the Days Creek reservoir site (p. 253). The average head, with a dam 100 feet high and an 80-foot drawdown, is estimated at 65 feet. The head for 90 per cent of the time is estimated at 40 feet and for 50 per cent of the time at 100 feet. The regulated flow is estimated from the records for 1911 above Elk Creek, near Tiller, and from seven years' records at Brockway. This site will probably be feasible only in connection with sites on the Umpqua River and will not be built until all those sites are utilized, so its construction is a long way in the future. Some 
water is pumped from the South Umpqua River for irrigation, but it is doubtful if the requirements will exceed the natural flow. Pumping is expensive, and there is ordinarily sufficient precipitation for the prune orchards, which are the principal users of water, so the reservoir will not be built for irrigation.

\section{Summary of potential power at undeveloped site 12RB 44}

[Head without drawdown, 100 feet; assumed drawdown, 80 feet; storage capacity, 60,000 acre-feet]

\begin{tabular}{|c|c|c|c|c|}
\hline \multirow{2}{*}{, } & \multicolumn{2}{|c|}{ Flow in second-feet } & \multicolumn{2}{|c|}{ Horsepower } \\
\hline & $\begin{array}{l}90 \text { per } \\
\text { cent of } \\
\text { time }\end{array}$ & $\begin{array}{l}50 \text { per } \\
\text { cent of } \\
\text { time }\end{array}$ & $\begin{array}{l}90 \text { per } \\
\text { cent of } \\
\text { time }\end{array}$ & $\begin{array}{l}50 \text { per } \\
\text { cent of } \\
\text { time }\end{array}$ \\
\hline $\begin{array}{l}\text { Natural flow } \\
\text { Regulated flow }\end{array}$ & $\begin{array}{r}90 \\
425\end{array}$ & $\begin{array}{l}750 \\
750\end{array}$ & $\begin{array}{r}720 \\
\times 1,360\end{array}$ & $\begin{array}{l}6,000 \\
6,000\end{array}$ \\
\hline
\end{tabular}

- Estimated head $\mathbf{4 0}$ feet.

\section{RIDDLE POWER SITE (12RB 45)}

The Riddle site comprises the stretch of the South Umpqua River from the Days Creek dam site to a point in the NE. $1 / 4$ sec. 19, T. 30 S., R. 5 W., near the town of Riddle. A dam about 20 feet high is proposed at a point a little below Days Creek, with a conduit along the right bank to the power house. The total fall is 125 feet, and the distance by river from the dam site to the proposed power house site is 13 miles. It might be more economical to develop the head by a series of dams 20 or 25 feet high. The Pacific Highway parallels the river along the lower part of this stretch, and the Southern Pacific Railroad passes through Riddle.

Summary of potential power at undeveloped site 12RB 45

[Head, 125 feet]

\begin{tabular}{|c|c|c|c|c|}
\hline & \multicolumn{2}{|c|}{ Flow in second-feet } & \multicolumn{2}{|c|}{ Horsepower } \\
\hline & $\begin{array}{l}90 \text { per } \\
\text { cent of } \\
\text { time }\end{array}$ & $\begin{array}{l}50 \text { per } \\
\text { cent of } \\
\text { time }\end{array}$ & $\begin{array}{l}90 \text { per } \\
\text { cent of } \\
\text { time }\end{array}$ & $\begin{array}{l}50 \text { per } \\
\text { cent of } \\
\text { time }\end{array}$ \\
\hline $\begin{array}{l}\text { Natural flow } \\
\text { Regulated flow }\end{array}$ & $\begin{array}{l}100 \\
430\end{array}$ & $\therefore 775$ & $\begin{array}{l}1,000 \\
4,300\end{array}$ & $\begin{array}{l}7,750 \\
7,750\end{array}$ \\
\hline
\end{tabular}

MYRTLE CREEK POWER SITE (12RB 46)

The Myrtle Creek site comprises the 7-mile stretch of the South Umpqua River from the Riddle power-house site to the town of Myrtle Creek. The fall is $\mathbf{7 0}$ feet. The power would probably be developed by low dams combined with conduits. The site possesses considerable power value for half the year, but at present the power has little value. Under present conditions the development of this site is dependent on the previous construction of the Perdue and Days Creek Reservoirs. The cost of construction would not be excessive if there were a larger low-water flow in the river. The site is paralleled by the Pacific Highway and the Southern Pacific Railroad. 
Summary of potential power at undeveloped site 12RB 46

[Head, 70 feet]

\begin{tabular}{|c|c|c|c|c|}
\hline & \multicolumn{2}{|c|}{ Flow in second-feet } & \multicolumn{2}{|c|}{ Horsepower } \\
\hline & $\begin{array}{l}90 \text { per } \\
\text { cent of } \\
\text { time }\end{array}$ & $\begin{array}{l}50 \text { per } \\
\text { cent of } \\
\text { time }\end{array}$ & $\begin{array}{l}90 \text { per } \\
\text { cent of } \\
\text { time }\end{array}$ & $\begin{array}{l}50 \text { per } \\
\text { cent of } \\
\text { time }\end{array}$ \\
\hline $\begin{array}{l}\text { Natural flow } \\
\text { Regulated flow }\end{array}$ & $\begin{array}{l}125 \\
435\end{array}$ & $\begin{array}{l}925 \\
925\end{array}$ & $\begin{array}{r}700 \\
2,430\end{array}$ & $\begin{array}{l}5,180 \\
5,180\end{array}$ \\
\hline
\end{tabular}

\section{RUCKLES POWER SITE (12RB 47)}

The Ruckles site includes a 9-mile stretch of the South Umpqua River from Myrtle Creek to a point 3 miles above Dillard. The total fall is 50 leet, so it would be necessary to develop the head by a series of low dams, as a 50-foot dam would flood the Southern Pacific Railroad and the Pacific Highway. The value of this site is not great under present conditions, and development is a long way in the future.

Sites similar to this one are feasible without storage only if so located that all the power can be used to take the place of steam power in some large market. If the Days Creek and Perdue Reservoirs are ever constructed this would probably be developed.

Summary of potential power at undeveloped site $12 R B \quad 47$

[Head, 50 feet]

\begin{tabular}{|c|c|c|c|c|}
\hline & \multicolumn{2}{|c|}{ Flow in second-feet } & \multicolumn{2}{|c|}{ Horsepower } \\
\hline & $\begin{array}{l}90 \text { per } \\
\text { cent of } \\
\text { time }\end{array}$ & $\begin{array}{l}50 \text { per } \\
\text { cent of } \\
\text { time }\end{array}$ & $\begin{array}{l}90 \text { per } \\
\text { cent of } \\
\text { time }\end{array}$ & $\begin{array}{l}50 \text { per } \\
\text { cent of } \\
\text { time }\end{array}$ \\
\hline $\begin{array}{l}\text { Natural flow } \\
\text { Regulated flow }\end{array}$ & $\begin{array}{l}130 \\
440\end{array}$ & $\begin{array}{l}940 \\
940\end{array}$ & $\begin{array}{r}520 \\
1,760\end{array}$ & $\begin{array}{l}3,760 \\
3,760\end{array}$ \\
\hline
\end{tabular}

\section{DILLARD POWER SITE (12RB 48)}

The Dillard site comprises an 11-mile stretch of the South Umpqua River from a point 3 miles above Dillard to a point 5 miles above Roseburg. The total fall is 60 feet, and the power would probably be developed by a series of low dams 15 or 20 feet high rather than by a conduit. The cost of construction would not be great, but without regulation the potential power is low during the summer. This site probably will not be utilized for 25 years or more.

Summary of potential power at undeveloped site $12 R B 48$

[Head, 60 feet]

\begin{tabular}{|c|c|c|c|c|}
\hline \multirow[b]{2}{*}{ ' } & \multicolumn{2}{|c|}{ Flow in second-feet } & \multicolumn{2}{|c|}{ Horsepower } \\
\hline & $\begin{array}{c}90 \text { per } \\
\text { cent of } \\
\text { time }\end{array}$ & $\begin{array}{l}50 \text { per } \\
\text { cent of } \\
\text { time }\end{array}$ & $\begin{array}{l}90 \text { per } \\
\text { cent of } \\
\text { time }\end{array}$ & $\begin{array}{l}50 \text { per } \\
\text { cent of } \\
\text { time }\end{array}$ \\
\hline $\begin{array}{l}\text { Natural flow } \\
\text { Regulated flow }\end{array}$ & $\begin{array}{l}141 \\
450\end{array}$ & $\begin{array}{l}1,000 \\
1,000\end{array}$ & $\begin{array}{r}677 \\
2,160\end{array}$ & $\begin{array}{l}4,800 \\
4,800\end{array}$ \\
\hline
\end{tabular}


ROSEBURG POWER SITE (12RB 49)

The Roseburg site comprises a 7-mile stretch of the South Umpqua River, with its lower end about 2 miles below Roseburg. The total head is a little uncertain, as the river survey of the Umpqua River indicates that the 400 -foot contour line crosses the South Umpqua about 2 miles below Roseburg, giving the lower end of the site an altitude about 50 feet less than that indicated by the topographic map of the Roseburg quadrangle, on which the 400 -foot contour line crosses the Umpqua River below the mouth of the South Umpqua. The total fall at this site is assumed to be 50 feet. The Roseburg site would be developed by two or three dams, with automatic controls at the power stations. If Oregon becomes a great manufacturing center, or if a method of cheap storage of electricity or cheap transmission over very long distances is discovered, this site will be feasible. Under present conditions it will not be developed.

Summary of potential power at undeveloped site 12RB 49

[Head, 50 feet]

\begin{tabular}{|c|c|c|c|c|}
\hline & \multicolumn{2}{|c|}{ Flow in second-feet } & \multicolumn{2}{|c|}{ Horsepower } \\
\hline$\cdot$ & $\begin{array}{l}90 \text { per } \\
\text { cent of } \\
\text { time }\end{array}$ & $\begin{array}{l}50 \text { per } \\
\text { cent of } \\
\text { time }\end{array}$ & $\begin{array}{l}90 \mathrm{per} \\
\text { cent of } \\
\text { time }\end{array}$ & $\begin{array}{l}50 \text { per } \\
\text { cent of } \\
\text { time }\end{array}$ \\
\hline $\begin{array}{l}\text { Natural flow } \\
\text { Regulated flow }\end{array}$ & $\begin{array}{l}141 \\
450\end{array}$ & $\begin{array}{l}1,000 \\
1,000\end{array}$ & $\begin{array}{r}564 \\
1,700\end{array}$ & $\begin{array}{l}4,000 \\
4,000\end{array}$ \\
\hline
\end{tabular}

\section{COW CREEK}

Cow Creek (see pl. 15) was measured on July 21, 1924, at a point in sec. 21 , T. 32 S., R. $5 \mathrm{~W}$., and the discharge was found to be 3.9 second-feet. Most of the summer flow is used for irrigation, the fall of the creek is not great, and the potential power is negligible.

\section{ELK CREEK}

Elk Creek, which is tributary to the Umpqua River at Elkton, has a fall of 13 to 15 feet to the mile for the 16 miles between Drain and the mouth, as determined by aneroid readings. On July 7, 1924, the flow at Drain was 5 second-feet and at Elkton 8 second-feet. The Q90 discharge is assumed to be 8 second-feet and the Q50 discharge 80 second-feet. The potential power per mile for 50 per cent of the time, based on these assumptions and a fall of 15 feet to the mile, would be 96 horsepower. This stream has no potential power value without storage. Storage for use on Elk Creek would not be feasible because of the low flow and little fall. A dam on the Ump- 
qua River to raise the water to an altitude of 100 feet would back water up Elk Creek for a distance of 4 miles. Above this point the stream has little value for power.

\section{MISCELLANEOUS SITES}

\section{LOON LAKE POWER SITE (12RB 50)}

The Loon Lake project involves the construction of a dam 80 feet high and storage at the Loon Lake reservoir site of 100,000 acre-feet, which is sufficient to equalize the ordinary annual flow. A pressure conduit $1 \frac{1}{2}$ miles long, including a short tunnel, would lead to the power house in the NE. $1 / 4$ SW. $1 / 4$ sec. 35, T. 22 S., R. 10 W., where a mean head of about 360 feet would be obtained. The stream flow and storage possibilities at this site are discussed in connection with the Loon Lake and Lake Creek reservoir sites (p. 254). The minimum regulated flow in the five years for which the records are available would have been 263 second-feet. One of the principal costs of this project would be the lands at the reservoir site. An alternative plan would be the construction of the Lake Creek reservoir at a point farther up the creek, where land values are lower. Under this plan Loon Lake would be used as a small regulating reservoir and would be drawn down about 5 feet to increase the storage capacity. With 45,000 acre-feet of storage in the Lake Creek reservoir, a Q90 flow of 150 second-feet could be obtained at Loon Lake. If it is economically feasible to build a higher dam at the Lake Creek site to increase the storage capacity to 75,000 acre-feet the $Q 90$ flow can be increased to 220 second-feet.

The Loon Lake dam site is on the crest of a great landslide that dammed Mill Creek, forming Loon Lake. The place of origin of the slide is a reentrant in a cliff about three-quarters of a mile west of the site. The slide at the creek is about half a mile wide and is covered with a dense growth of ferns and pines. Blocks of sandstone, some of which are 50 feet in diameter, are visible through the vegetation. Great pine trees growing on the slide indicate that it originated more than 200 years ago, and consequently the materials have had plenty of time to settle. Thus there is little danger of the slide being washed out during flood periods. The absence of springs on the downstream end indicates that it is fairly impermeable. Furthermore, driftwood along the shore shows that the slide holds when the lake is $\mathbf{1 0}$ feet higher than it was at the time of visit.

The east abutment consists of loose blocks of sandstone near the creek, and sandstone crops out a few feet up the bank. It is believed that an 80-foot rockfill dam would be successful, so far as leakage is concerned, although the engineering problem of providing a suitable core properly anchored in the slide will be the chief difficulty. The huge sandstone blocks in the slide, however, will help to solve this problem. Loon Lake occupies a narrow V-shaped valley underlain by Tertiary shale and sandstone, and there should be practically no leakage through these rocks.

The following table shows the potential power at this site in connection with the Loon Lake and Lake Creek Reservoirs. 
Summary of potential power at undeveloped site $12 R B 50$

Storage 100,000 acre-feet in Loon Lake Reservoir

[Head without drawdown, 385 feet; assumed drawdown, 71 feet. Head, with natural flow without dam, 314 feet]

\begin{tabular}{|c|c|c|c|c|}
\hline & \multicolumn{2}{|c|}{ Flow in second-feet } & \multicolumn{2}{|c|}{ Horsepower } \\
\hline & $\begin{array}{l}90 \text { per } \\
\text { cent of } \\
\text { time }\end{array}$ & $\begin{array}{l}50 \text { per } \\
\text { cent of } \\
\text { time }\end{array}$ & $\begin{array}{l}90 \text { per } \\
\text { cent of } \\
\text { time }\end{array}$ & $\begin{array}{l}50 \text { per } \\
\text { cent of } \\
\text { time }\end{array}$ \\
\hline $\begin{array}{l}\text { Natural flow } \\
\text { Regulated flow }\end{array}$ & $\begin{array}{r}6 \\
263\end{array}$ & $\begin{array}{l}117 \\
277\end{array}$ & $\begin{array}{r}151 \\
7,570\end{array}$ & $\begin{array}{l}2,940 \\
7,980\end{array}$ \\
\hline
\end{tabular}

Storage 45,000 acre-feet at Lake Creek site

[Head, 309 feet]

\begin{tabular}{ll|r|r|r|r}
\hline Regulated flow & 150 & 185 & 3,700 & 4,570 \\
\hline
\end{tabular}

This would be a valuable plant in any large system, because of the storage, and this site will undoubtedly be utilized in the next 25 years, water being stored either at this site or at the Lake Creek Reservoir site.

\section{MILL CREEK POWER SITE (12RB 51)}

The Mill Creek site would utilize the lower portion of Mill Creek, where there is a fall of 85 feet in a distance requiring a little over 4 miles of conduit. This site would be feasible only if the flow of Mill Creek were regulated by the construction of the Loon Lake or Lake Creek Reservoir. The conduit would probably follow the right bank, with one or two short tunnels across sharp bends. The stream flow at this site would be slightly greater than at the Loon Lake site because of the inflow of Camp Creek.

Summary of potential power at undeveloped site 12RB 51

[Head, 85 feet]

\begin{tabular}{|c|c|c|c|c|}
\hline & \multicolumn{2}{|c|}{ Flow in second-feet } & \multicolumn{2}{|c|}{ Horsepower } \\
\hline & $\begin{array}{l}90 \text { per } \\
\text { cent of } \\
\text { time }\end{array}$ & $\begin{array}{l}50 \text { per } \\
\text { cent of } \\
\text { time }\end{array}$ & $\begin{array}{l}90 \text { per } \\
\text { cent of } \\
\text { time }\end{array}$ & $\begin{array}{l}50 \text { per } \\
\text { cent of } \\
\text { time }\end{array}$ \\
\hline $\begin{array}{l}\text { Natural flow } \\
\text { Regulated flow, Loon Lake Reservoir, 100,000 acre-feet. } \\
\text { Regulated flow, Lake Creek Reservoir, 45,000 acre-feet }\end{array}$ & $\begin{array}{r}10 \\
267 \\
154\end{array}$ & $\begin{array}{l}200 \\
360 \\
268\end{array}$ & $\begin{array}{r}68 \\
1,810 \\
1,050\end{array}$ & $\begin{array}{l}1,360 \\
2,440 \\
1,820\end{array}$ \\
\hline
\end{tabular}

\section{LAKE CREEK POWER SITE (12RB 52)}

The Lake Creek project depends on the construction of the Lake Creek Reservoir, which would be used primarily to regulate the flow of Lake Creek at the Loon Lake power site. However, a minimum head of 50 feet and a mean head of 95 feet could be obtained at the Lake Creek dam. By operating the plant at the Lake Creek Reservoir in connection with the proposed Loon Lake plant from 900 to 1,500 horsepower could be obtained during the low-water season. The storage in Loon Lake could be used for the purpose of regulating the daily discharge for the Loon Lake plant. With regard to physical con- 
ditions alone, the Loon Lake reservoir and power project is preferable to a combination of the Loon Lake and Lake Creek sites. But the complications involved in flooding a large area of agricultural land may be prohibitive, whereas the Lake Creek site contains no buildings of any kind, and the only damage would be to timber; so, as a practical power project, a combination of the Lake Creek and Loon Lake sites may be most feasible.

The Lake Creek site was not examined by a geologist. The rock at the dam site is sandstone, which is exposed in the bed of the stream and on both banks. It is exposed on the left abutment to a height of about 75 feet and on the right abutment to a height of possibly 50 feet. There is a ridge extending down to the ijght abutment, with a small stream just below it. At the dam site the ridge is narrow at the top but gradually increases in width back from the stream. The ridge is sufficiently wide to serve as a base for an earth-fill dam 25 feet high if a dam higher than 125 feet were desired in the stream itself.

Potential power at site 12RB 52

[Head without drawdown, 127 feet; assumed drawdown, 75 feet; storage capacity, 45,000 acre-feet]

\begin{tabular}{|c|c|c|c|c|}
\hline & \multicolumn{2}{|c|}{ Flow in second-feet } & \multicolumn{2}{|c|}{ Horsepower } \\
\hline . & $\begin{array}{l}90 \text { per } \\
\text { cent of } \\
\text { time }\end{array}$ & $\begin{array}{l}50 \text { per } \\
\text { cent of } \\
\text { time }\end{array}$ & $\begin{array}{l}90 \text { per } \\
\text { cent of } \\
\text { time }\end{array}$ & $\begin{array}{l}50 \text { per } \\
\text { cent of } \\
\text { time }\end{array}$ \\
\hline $\begin{array}{l}\text { Natural flow } \\
\text { Regulated flow }\end{array}$ & $\begin{array}{r}3 \\
124\end{array}$ & $\begin{array}{r}58 \\
162\end{array}$ & $\begin{array}{r}30 \\
894\end{array}$ & $\begin{array}{r}590 \\
1,460\end{array}$ \\
\hline
\end{tabular}

The survey at this dam site was carried to a height of 125 feet above the water surface, which gives a storage capacity of 45,000 acre-feet. Adding 25 feet to the height of the dam would necessitate a dike about 1,000 to 1,500 feet long and 25 feet high, but it would add 30,000 acre-feet to the storage capacity and 1,730 horsepower to the power available at Loon Lake. It therefore seems probable that the extra height would be justified.

\section{MARKET}

There is only a small market for power at present in the basin of the Umpqua River. Transmission lines, however, are already built north to Portland and south to San Francisco, and power can be transmitted from the Rogue River to both places, so the time of development of the Umpqua River sites depends on the rate of growth of the market for power in Oregon and California, and the relative cost of developing the water-power sites in the Umpqua River Basin compared with the cost of sites nearer those markets. Between 1920 and 1926 the production of electricity by public-utility plants in California and Oregon increased from 4,212,000,000 to $7,729,000,000$ kilowatt-hours, an increase of 88 per cent in 6 years. At the end of 1926 the installed capacity of water-power plants in California was 1,917,000 horsepower and in Oregon 242,000 horsepower. From 1921 to 1926 the capacity of developed power plants in California increased 768,000 horsepower. The water-power re- 
sources of California are estimated at 4,603,000 horsepower for 90 per cent of the time and 6,674,000 horsepower for 50 per cent of the time. The corresponding figures for Oregon are 3,665,000 and 6,715,000 horsepower. Thus California has only 25 per cent more potential power at low water and no more potential power for 50 per cent of the time, and yet the installed capacity of its water-power plants is eight times that of plants in Oregon.

The figures show that a large amount of undeveloped power is still available in California but that most of the cheaper and more easily developed sites have undoubtedly been utilized. In Oregon so far there has been comparatively little development, and there are many sites which can be developed at a low cost. As California uses about eight times as much power as Oregon and has already utilized about eight times as much of its resources, it is probable that the cost of new plants in California will soon exceed the cost of development in Oregon plus the added cost of transmission. The most accessible rivers in Oregon to the California markets are the Klamath, the Rogue, and the Umpqua. The Klamath River in Oregon will soon be completely developed, and most of its power goes to California. The Rogue River would probably supply the market for Oregon power in California for several years, but as the sites on the Umpqua River are somewhat cheaper to develop than most of those on the Rogue River, it is probable that some of the power on the Umpqua River will be required within 10 years and that in the not very distant future there will be a market sufficient to absorb all the cheaper power on the North Umpqua River that can be developed at sites above. Winchester. In time there will be a market in Oregon and California for practically all the power available on the North Umpqua and Umpqua Rivers.

In addition to the California market there is a growing demand for power in southwestern Oregon which is now supplied by plants on the Klamath, Rogue and Umpqua Rivers. Very possibly some power will be required to the north, in Eugene, Salem, Albany, and Portland. 


\section{INDEX}

A

Acknowledgments for aid

- 16, 46-47, 102-103, 170-171

Almond, Calif., monthly discharge of Temescal Creek near

Alpine, Calif., monthly discharge of South Fork of Cuyamaca Water Co.'s flume near

monthly discharge of South Fork of San Diego River near

Arnold Meadow, Calif., monthly discharge of Chiquito Creek near.

Arrowhead Springs, Calif., monthly discharge of Strawberry Creek near-

monthly discharge of Waterman Canyon Creek near.

Arroyo Seco (Los Angeles Basin), Calif., monthly discharge at station on.

Arroyo Seco (Salinas Basin), Calif., monthly discharge at station on ...........-

Avery, Calif., monthly discharge of Middle Fork of Stanislaus River near...

monthly discharge of North Fork of Stanislaus River near

Utica Gold Mining Co.'s canal near.

Azusa, Calif., monthly discharge of Rogers Creek near.

monthly discharge of San Gabriel River and canals near

Southern California Edison Co.'s canal near. 208-209

tunnel diversion near.............. 210

\section{B}

Baker Station, Calif., monthly discharge of Relief Creek near...................

Bakersfield, Calif., monthly discharge of Kern River near

Barre, Vt., Main Street in, after peak of flood
of 1927
Barrows, H. K., quoted

Barre, Vt., Main Street in, after peak of flood
of 1927
Barrows, H. K., quoted

Barre, Vt., Main Street in, after peak of flood
of 1927.... Plate 3
Barrows, H. K., quoted....

Basin Creek, Calif., monthly dischąrge at

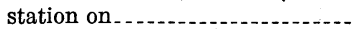

Bear Creek (Mokelumne Basin), Calif., monthly discharge at stations on.

Bear Creek (San Joaquin Basin), Calif., monthly discharge at station on.

Bear Creek (Tule Basin), Calif., monthly discharge at station on

Bellows Falls, Vt., flood of 1927 on Connecticut River at Plate 7

Bernardo, Calif., monthly discharge of San Dieguito River at and near.... 193-194
Big Creek, Calif., monthly discharge of Big Creek near - . . . monthly discharge of Pitman Creek at.-

Big Creek (King Basin), Calif., monthly discharge at station on ...............

Big Creek (San Joaquin Basin), Calif., monthly discharge at station on. monthly discharge of San Joaquin River above.

Black Canyon Creek, Calif., monthly discharge at station on

Black Rock power site, Oreg., description of - 310 Boulder Creek, Calif., monthly discharge at stations on

Boulder Creek power site, Oreg., description of

Boundary dam site, Oreg.,view of........... Plate 21

Boundary power site, Oreg., description of - 275-277

Bonsall, Calif., monthly discharge of San Luis Rey River at..................... 196

Borel Canal, Calif., monthly discharge at station on ........... 127

Bradley, Calif., monthly discharge of Nacimiento River near................ 218

Bradley power site, Oreg., description of... 267-268

Bridge power site, Oreg., description of...- 265-266

Bright Angel Creek, Ariz., analyses of water of

Bryson, Calif., monthly discharge of Nacimiento River near................ 217

Buchanan reservoir site, Calif., monthly discharge of Chowchilla River near.

Buck Meadows, Calif., monthly discharge of Middle Fork of Tuolumne River near.

monthly discharge of South Fork of Tuolumne River near......... 155

Tuolumne River near................ 151

Cajon Creek, Calif., monthly discharge at station on

Calabasas, Calif., monthly discharge of Malibu Creek near............... 215 monthly discharge of Triunfo Creek near. $\quad 215$ Calaveras River, Calif., description of....... $\quad 119$ monthly discharge at stations on ........ 162

California, Great Valley of, geography of... 103-104 origin of present surface of

Camp Creek, Calif., monthly discharge at stations on - 168

Carrizo Creek, Calif., monthly discharge at station on.......................... 197 
Page

Cattle Mountain, Calif., monthly discharge of East Fork of Granite Creek near.

monthly discharge of Granite Creek near.

Middle Fork of Granite Creek near.

Checker House Bridge, Vt., after flood of 1927 . . . . . . 13

Cherry Creek, Calif., monthly discharge at stations on

Chiquito Creek, Calif., monthly discharge at stations on

Chowchilla River, Calif., monthly discharge at station on ........

City Creek, Calif., monthly discharge at station on.

City Creek Water Co.'s canal, Calif., monthly discharge at station on . ...........

Claremont, Calif., monthly discharge of San Antonio Creek near........... monthly discharge of Southern California Edison Co.'s canal near ......... 207, 208

Clark, G. G., McNary, J. V., and Jarvis, C. S., New England floods and highways 90-100

Clark, W. O., quoted.

Clark ranch dam site, Oreg., view of ...... Plate 22 Clark ranch power site, Oreg., description of 277-279 Clearwater River Basin, Oreg., power sites in

Clearwater River power site, Oreg., description of

Clements, Calif., monthly discharge of Bear Creek near..................... 163

monthly discharge of Mokelumne River near-............................ 164

Cliff Camp, Calif., monthly discharge of North Fork of Kings River near

Coffee Creek power site, Oreg., description of - .

Coles Valley power site, Oreg., description of - .

Coles Valley reservoir site, Oreg., description of - . - . 250-251

Colorado River, bed load of

26

sampler used in collection of silt samples from

silt samples from, collection of suspended matter in ................. 29-40 suspended matter in, annual load of .... 24-26 previous investigations of........... 16-17 quantity of, determination of ........ 19-20 variation in ..... 20-24 recent investigations of . . . . reservoir space required for $\ldots . . . . . . .-27-28$ water of, analysis of . . . chloride in

collection of samples.

composition of ........... 3-6

methods of analysis................... 2-3 suspended matter in utilization of . . . . .

water samples from, collection of....... 17-18

suspended matter in ................... 41-44

Colton, Calif., monthly discharge of Meeks \& Daley Canal near........... 203, 206 monthly discharge of Warm Creek near.- 203
Connecticut River, N. H., after flood of

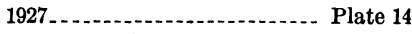

Connecticut River, Vt.-Mass., flood of 1927 on

Connecticut River, peak flood stages of, during flood of 1927 , graph showing -

Plate 8

principal floods of. $87-90$

Copeland Creek dam site, Oreg., right bank at . . .

Copeland power site, Oreg., description of - 271-273

Cosumnes River, Calif., description of ....... 120

monthly discharge at station on . ....... 168

North Fork of, monthly discharge at stations on

Cottonwood Creek, Calif., monthly discharge at station on

Cow Creek, Oreg., undeveloped power on..- 316

Crafton headworks, Calif., monthly discharge of Mill Creek at...........

Craftonville, Calif., monthly discharge of Mill Creek and canals near.... 201, 202

Cuyamaca Water Co.'s flume, Calif., monthly discharge at stations on

South Fork of, monthly discharge at station on.................................

\section{D}

Dalton Creek, Calif., monthly discharge at station on .........................

Dalton diversion, Calif., monthly discharge at station on

Days Creek power site, Oreg., description of

Days Creek reservoir site, Oreg., description of . . .

Deadman Creek power site, Oreg., descrip-

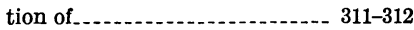

Deer Creek, Calif., monthly discharge at stations on ........ 129, 137

Dehesa, Calif., monthly discharge of Sweetwater River near...................

Del Mar, Calif., monthly discharge of San Dieguito River near.............. 194

Deluz Station, Calif., monthly discharge of Santa Margarita River near.....

Descanso, Calif., monthly discharge of Sweetwater River near....................

Devil Canyon Creek, Calif., monthly discharge at station on

Diamond Lake, Oreg., plan of.............. Plate 18

Diamond Lake and Mount Thielsen, Oreg., view of ......................... Plate 16

Diamond Lake reservoir site, Oreg., descrip-

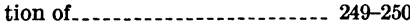

Dillard power site, Oreg., description of ..... 315

Dinkey Creek, Calif., monthly discharge at stations on ..........................

monthly discharge of North Fork of Kings River above...............

Dinkey Meadows, Calif., monthly discharge

Dry Creek, Calif., monthly discharge at stations on 
Duarte, Calif., monthly discharge of Fish Creek near . . ........................

Dulzura, Calif., monthly discharge of Cottonwood Creek near. -

monthly discharge of Dulzura conduit near

Pine Valley Creek near

Dulzura conduit, Calif., monthly discharge at station on ...........................

Dumont power site, Oreg., description of -..-

\section{E}

East Fork, Calif., monthly discharge of Deer Creek below...............

East Highlands, Calif., monthly discharge of Plunge Creek near.

East San Pasqual ditch, Calif., monthly discharge at station on

Eaton Creek, Calif., monthly discharge at station on

El Dorado, Calif., monthly discharge of North Fork of Cosumnes River near

Eleanor Creek, Calif., monthly discharge at stations on -....

Eleanor Trail Crossing, Calif., monthly discharge of Cherry Creek at........ monthly discharge of Eleanor Creek at.-

Electra, Calif., monthly discharge of Mokelumne River at.............. 163

Elk Creek, Oreg., undeveloped power on _. 316-317

Elsinore, Calif., monthly discharge of San Jacinto River near.

monthly discharge of Temescal Creek near.

Temescal Water Co.'s diversion near-

Enosburg Falls, Vt., highway bridge damaged by flood of 1927 at......... Plate 4

Erskine Creek, Calif., monthly discharge at station on -

Escondido, Calif., monthly discharge of East San Pasqual ditch near

monthly discharge of Guejito Creek near.

Santa Ysabel Creek near. ..........

West San Pasqual ditch near......

Escondido Mutual Water Co.'s canal, Calif., monthly discharge at station on.

Exchequer, Calif., monthly discharge of Merced River at

F

Fallbrook, Calif., monthly discharge of Santa Margarita River near.

Falls Creek, Calif., monthly discharge at station on

Farmington, Calif., monthly discharge of South Channel of Littlejohns Creek at.

Fillmore, Calif., monthly discharge of Santa Clara River at

Fish Creek, Calif., monthly discharge at station on Fish Creek power site, Oreg., description of - 307 Fish Lake power site, Oreg., description of. 309-310
Fish Lake Reservoir site, Oreg., description of

Floods in New England, probability of recurrence of

Fontana, Calif., monthly discharge of Fontana pipe line near.

monthly discharge of Lytle Creek near ... $\quad 205$

Fontana pipe line, Calif., monthly discharge at station on .................... 205

Forest Home, Calif., monthly discharge of Mill Creek at and near...........

Foster, Calif., monthly discharge of San Vicente Creek at.

Fresno Flume \& Lumber Co.'s upper and lower flumes, Calif., monthly discharge at stations on............ 144

Fresno River, Calif., description of . ....... 117

monthly discharge at station of ........ 144-145

Friant, Calif., monthly discharge of San Joaquin River near.............. 139

Fullers Meadow, Calif., monthly discharge of Jackass Creek near.

monthly discharge of West Fork of Jackass Creek near

\section{G}

Galt, Calif., monthly discharge of Dry Creek near.................................

Gila River, Ariz., water of, analyses of Glendora, Calif., monthly discharge of Dalton Creek near.

monthly discharge of Dalton diversion

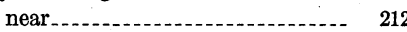

Glide dam site, Oreg., view of . ............ Plate 22

Glide power site, Oreg., description of . .-.- 281-284 Golden Rock ditch, Calif., monthly discharge at station on

Gorham, N. H., effects of flood of 1927 at.-. Plate 7

Grand Canyon, Ariz., suspended matter in Colorado River near........ 29-35, 41-42

Granite Creek, East Fork of, Calif., monthly discharge at station on ............ 142

Middle Fork of, monthly discharge at station on . . .

monthly discharge at station on ........-

West Fork of, monthly discharge at station on -

Greenspot pipe line, Calif., monthly discharge at station on (n)

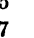
42

Guejito Creek, Calif., monthly discharge at station on . .................................

\section{$\mathrm{H}$}

Haines Creek, Calif., monthly discharge at stations on ................... 213

Haverhill, N. H., flood of 1927 near...... Plate 12

Havilah, Calif., monthly discharge of Basin Creek near.................. 128

Helm Creek, Calif., monthly discharge at station on . .

Hernandez, Calif., monthly discharge of McCoy Creek near................

monthly discharge of San Benito River at.

Herndon, Calif., monthly discharge of San Joaquin River at. ..................

\section{1}

9

3

43


Hetch Hetchy, Calif., monthly discharge of Cherry Creek near............. monthly discharge of Eleanor Creek near. Falls Creek near

Tuolumne River near.

Highland, Calif., monthly discharge of City Creek near.

monthly discharge of City Creek Water Co.'s canal near.

Hoffman Meadows, Calif., monthly discharge of South Fork of San Joaquin River near.

Holyoke, Mass., flood of 1927 passing over Holyoke Dam at............. Plate 9

Horseshoe Bend, Calif., monthly discharge of Merced River at................ 146

Horseshoe Bend dam site, Oreg., view of-- Plate 23 Horseshoe Bend power site, Oreg., description of ........... 284-286

Hot Springs, Calif., monthly discharge of Deer Creek at.................. monthly discharge of Tyler Creek near.White River near.

oward, C. S , ang

Quality of water of the Colorado River in 1926-1928

Suspended matter in the Colorado River

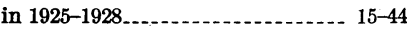

Hume, Calif., monthly discharge of Kings River near

\section{I}

Illilouette Creek, Calif., monthly discharge at station on

Ione, Calif., monthly discharge of Dry Creek near

Iron Creek, Calif., monthly discharge at station on

monthly discharge of North Fork of San Joaquin River below

Isabella, Calif., monthly discharge of Erskine Creek near.

monthly discharge of Kern River at.....

\section{J}

Jackass Creek, Calif., monthly discharge at stations on -

West Fork of, monthly discharge at station on.

Jackass Meadow, Calif., monthly discharge of Jackass Creek near...........

Jacksonville, Calif., monthly discharge of Tuolumne River near...........

monthly discharge of Woods Creek near -

Jarvis, C. S., with Clark, G. G. and McNary, J. V., New England floods and highways

Jenny Lind, Calif., monthly discharge of Calaveras River at...............

Jolon, Calif., monthly discharge of San Antonio River near..............

Jones, B. E., and Stearns, H. T., Waterpower resources of the Umpqua River and its tributaries, Oregon.

Julian, Calif., monthly discharge of Boulder Creek near
$\mathbf{K}$

Page

Kaweah, Calif., monthly discharge of North Fork of Kaweah River at........ 133

Kaweah River, Calif., description of....-...-. 116 monthly discharge at station on

North Fork of, monthly discharge at station on

South Fork of, monthly discharge at station on

Keenbrook, Calif., monthly discharge of Cajon Creek near...............

monthly discharge of Lone Pine Creek near.

Kelley's Smith Ferry dam site, Oreg., bed of stream at

Kelley's Smith Ferry power site, Oreg., description of . . . 294-297

Kellogg dam site, Oreg., view of ........... Plate 24

Kellogg power site, Oreg., description of -- 292-294

Kelsay power site, Oreg., description of ...... 263

Kelsay Valley reservoir site, Oreg., description of

Kern and Tulare Lake Basins, Calif., description of

Kern River, Calif., description of -........ 114-116 monthly discharge at stations on . ..... 125-127

South Fork of, monthly discharge at station on -

Kern River No. 3 Canal, Calif., monthly discharge at station on

Kern River Power Co.'s canal, Calif., monthly discharge at station on .- 127

Kernville, Calif., monthly discharge of Kern River at and near.............. 125, 127

monthly discharge of Kern River Power Co.'s canals at.................... 127

Salmon Creek near.

Kings City, Calif., monthly discharge of San Lorenzo Creek near............... 218

Kings River, Calif., description of ........... 117 monthly discharge at stations on ...... 134-135

North Fork of, monthly discharge of stations on . . 135-136

Kingsburg, Calif., monthly discharge of Kings River at. .....................

Kinnison, H. B., The New England flood of November, 1927 . . . .

Knights Ferry, Cadif., monthly discharge of Oakdale Canal near............. 161

monthly discharge of South San Joaquin Canal near. ...................... 161

Stanislaus \& San Joaquin Water Co.'s canal at........................... 162

Stanislaus River at and near....... 158-159

Knowles, Calif., monthly discharge of Fresno River near

$144-145$

L

La Grange, Calif., monthly discharge of Modesto Canal near............. monthly discharge of Sierra \& San Francisco Power Co.'s canal near-..-. 156

Tuolumne River above.............. 151

Tuolumne River and canals near.-.- 152

$\begin{array}{rr}221- & \text { Turlock Canal near-157 } \\ 320 & \text { Lake Creek Basin, Oreg., power sites in.-.- 303-305 }\end{array}$

Lake Creek No. 1 power site, Oreg., description of 


\section{Page}

Lake Creek No. 3 power site, Oreg., description of - . - 304-305

Lake Creek No. 2 power site, Oreg., description of

Lake Creek power site, Oreg., description of

Lake Creek Reservoir site, Oreg., description of

Lake Florence, Calif., monthly discharge of South Fork of San Joaquin River near.

Lakeside, Calif., monthly discharge of Boulder Creek near. monthly discharge of Cuyamaca Water Co.'s flume near................. 191-192

San Diego River and flume near.-... $\quad 190$

San Diego River at and near. ..... 189-190

Lancha Plana, Calif., monthly discharge of Mokelumne River near..........

Lathrop, Calif., monthly discharge of San Joaquin River at. .................

Lava Creek power site, Oreg., description of - 305-306

Lemolo Falls, Oreg., view of -............ Plate 20

Lemolo Falls power site, Oreg., description of - 264

Lemon Cove, Calif., monthly discharge of Kaweah River near

Little Colorado River, Ariz., analyses of

water of ................................

Little River, Oreg., undeveloped power on..

Little Santa Anita Creek, Calif., monthly discharge at station on

Littlejohns Creek, South Channel of, Calif., monthly discharge at station on.

Livingston, Calif., monthly-discharge of Merced River near.............

Loafer Creek power site, Oreg., description of

Lockeford, Calif., monthly discharge of Bear Creek near ..................

Lompoc, Calif., monthly discharge of Santa Ynez River near.......................

Lone Pine Creek, Calif., monthly discharge at station on ......... 206

Loon Lake, Oreg., view of ............. Plate 19

Loon Lake power site, Oreg., description of - 317-318

Loon Lake reservoir site, Oreg., description of - . -

Los Angeles River Basin, Calif., description of - 179

Love, S. K., analyses by . ............ 13, 14, 43, 44

Lower Steamboat Creek power site, Oreg., description of

Lytle Creek, Calif., monthly discharge at stations on - . - . 204-205

Lytle Creek Canals, Calif., monthly discharge at intake of

M

McCoy Creek, Calif., monthly dischärge at station on.

McGlashan, H. D., Surface water supply of Pacific slope basins in southern California, 1894-1927........... 169-219

Surface water supply of San Joaquin River Basin, Calif., 1895-1927 . . 101-168
McNary, J. V., with Clark, G. G., and Jarvis, C. S., New England floods and

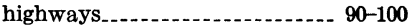

Malibu Creek, Calif., monthly discharge at station on ..........................

Malibu Creek Basin, Calif., description of -..

Matagual Creek, Calif., monthly discharge at station on ..........................

Mather, Calif., monthly discharge of Middle Fork of Tuolumne River near.-

Meadowbrook, Calif., monthly discharge of North Fork of Kings River below

Page

Meeks \& Daley Canal, Calif., monthly discharge at station on . ........... 203, 206

Mendon Road near Rutland, Vt., before and after flood of 1927 ................ Plate 6

Mentone, Calif., monthly discharge of Greenspot pipe line near.......... 200

monthly discharge of Santa Ana River and canals near.................... 199

Santa Ana River near................ 198-199

Southern California Edison Co.'s canal near

Merced Falls, Calif., monthly discharge of Merced River near............. $\quad 147$

Merced River, Calif., description of . ...... 117-118 monthly discharge at stations on . ..... 145-148

South Fork of, monthly discharge at station on -......................... 149

Mesa Grande, Calif., monthly discharge of Black Canyon Creek near.......-

monthly discharge of San Luis Rey River near

Santa Ysabel Creek near............. 193

Michigan Bar, Calif., monthly discharge of Cosumnes River at...............

Mill Creek, Calif., monthly discharge at stations on - 201-202

Mill Creek power canals, Calif., monthly discharge at stations on

Mill Creek power site, Oreg., description of.- 318

Miller Bridge, Calif., monthly discharge of Middle Fork of San Joaquin River at.......................... 141

Missisquoi River, Vt., flood of 1927 on....- Plate 4

Modesto, Calif., monthly discharge of Tuolumne River at....................

Modesto Canal, Calif., monthly discharge at station on

Mokelumne River, Calif., description of -..-.

Licking Fork of, monthly discharge at station on

Middle Fork of, monthly discharge at station on - .

monthly discharge at stations on . ..... 163-165

North Fork of, monthly discharge at stations on.

163

South Fork of, monthly discharge at station on.....

Mono Creek (San Joaquin Basin), Calif., monthly discharge at station on.-

Mono Creek (Santa Ynez Basin), Calif., monthly discharge at station on..

monthly discharge of Santa Ynez River above 
Monrovia, Calif., monthly discharge of Monrovia pipe line near.

monthly discharge of Sawpit Creek near.

Monrovia pipe line, Calif., monthly discharge at station on . .

Montpelier, Vt., Main Street in, after peak of flood in 1927

Moore Creek, Calif., monthly discharge of North Fork of Mokelumne River above

Mugler Meadow, Calif., monthly discharge of Chiquito Creek near.

Myrtle Creek power site, Oreg., description of .

$\mathrm{N}$

Nacimiento River, Calif., monthly discharge at stations on

Nellie, Calif., monthly discharge of Escondido Mutual Water Co.'s canal near..monthly discharge of Pauma Creek near.

San Luis Rey River near.............

West Fork of San Luis Rey River near.

Nestor, Calif., monthly discharge of Tia Juana River near...................

New England, map of, showing rainfall for storms of October, 1869, and November, 1927................... Plate 2

spillways in, necessity for 96-97

New England flood of November, 1927, cost of repairs and replacements of roads and bridges damaged by _- 92-93

damage caused by .................... 82-83 effect of reservoirs on flood flow during -- 80-81 extent of -

general features of . .

maximum discharge of

methods used in determining flood flows for

$68-71$

paved highways, superiority of, during -- 95-96 relation of highway damage to total damage caused by

reopening roeds to traffic ofter structures lost during survey of flood damages to highways and bridges during................... 91-92

New England floods and highways.......... 90-100

New England highways and bridges, survey of flood damage to............... 91-92

New England storm of November, 1927,

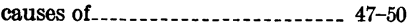

intensity and distribution of rainfall during

$55-60$

rainfall records for 50-55

storms, severe, prior to.

Newman, Calif., monthly discharge of San Joaquin River near

North Fork, Calif., monthly discharge of Kings River above..................

North Umpqua River, Oreg., power sites on

profile of, showing location of dam sites............................ Plate 17

variation in flow of . ................. 238

North Umpqua River Basin, Oreg., records at temporary gaging station in. 241-242
O

Page

Oak Creek dam site, Oreg., view of........ Plate 23

Oak Creek power site, Oreg., description of - 286-288

Oakdale, Calif., monthly discharge of Stanislaus River at

Oakdale Canal, Calif., monthly discharge at station on .............................

Oakland Recreation Camp, Calif., monthly discharge of South Fork of Tuolumne River near................

Oceanside, Calif., monthly discharge of San Luis Rey River near.............

Ockenden, Calif., monthly discharge of Dinkey Creek near...............

Ojai, Calif., monthly discharge of Ventura River near. . 216

Olivarian Brook, N. H., flood of 1927 on.. Flate 12 Onyx, Calif., monthly discharge of South Fork of Kern River near. . ...... 128

Oregon, map of southwestern part of......- Plate 15

Orford, N. H., bridge at, during flood of 1927 . . . . . Plate 10

Otter Creek, Vt., flood of 1927 on........... Plate 5

$\mathbf{P}$

Pacific Highway power site, Oreg., description of

Pacific slope basins of southern California, gaging stations in

maximum and minimum discharges in. 186-187 measurement of the flow of streams in . 169-170 monthly discharge at stations in ....... 188-219 reports containing records of flow of streams in

Pacoima Creek, Calif., monthly discharge at station on . . .

Pajaro River, Calif., monthly discharge at station on ................ 219

Pajaro River Basin, Calif., description of . - 182-183 Pala, Calif., monthly discharge of San Luis Rey River at and near........-

Park, Calif., monthly discharge of Sly Park Creek at.

196

Pasadena, Calif., monthly discharge of Arroyo Seco near.

monthly discharge of Eaton Creek near.-

Precipice Canyon Water Co.'s diversion near ......................

Pauma Creek, Calif., monthly discharge at stations on . .

Peabody River, N. H., after flood of 1927 .. Plate 7

Perdue power site, Oreg., description of .... 313

Perdue reservoir site, Oreg., description of_. 252-253

Piedra, Calif., monthly discharge of Kings

River at....................... 134-135

Pierce, C. H., quoted..................... 89, 90

Piermont, N. H., site of bridge at, after flood of 1927 ................... Plate 14

Pine Valley Creek, Calif., monthly discharge of station on.

188

Piru, Calif., monthly discharge of Piru Creek near.

Pitman Creek, Calif., monthly discharge at station on.

Pleasant Valley, Calif., monthly discharge of Camp Creek near.............

monthly discharge of North Fork of Cosumnes River near. 
Pleyto, Calif., monthly discharge of San Antonio River at

Plunge Creek, Calif., monthly discharge at station on

Porterville, Calif., monthly discharge of South Fork of Tule River near..-

monthly discharge of Tule River near -..

Potter Creek power site, Oreg., description of - .

Prado, Calif., monthly discharge of Santa Ana River near.

Precipice Canyon Water Co.'s diversion, Calif., monthly discharge at station on. 214

Proctor, Vt., flood of 1927 at . .

Public lands, classification and use of -..... 222-223 reports on development of water power on 223-224

\section{R}

Railroad Flat, Calif., monthly discharge of Licking Fork of Mokelumne River near...............................

monthly discharge of South Fork of Mokelumne River near

Ramona, Calif., monthly discharge of Santa Maria Creek near.

monthly discharge of Santa Ysabel Creek near.

Rancheria Creek, Calif., monthly discharge of Kings River below

Relief Creek, Calif., monthly discharge at station on.

Rialto Canals, head gates of, Calif., monthly discharge of Lytle Creek at...-.. 205

Richford, Vt., flood scene in 1927 in

Richmond, Vt., Checker House Bridge near, after flood of 1927 . .............. Plate 13

highway in use soon after flood of 1927 near............................ Plate 14

Riddle power site, Oreg., description of.... 314

Rock Creek, Oreg., undeveloped power on - 308-309

Rock Creek power site, Oreg., description of - 2 - 279-281

Rogers Creek, Calif., monthly discharge at station on - .

Roseburg power site, Oreg., description of-- 316 Ruckles power site, Oreg., description of..... 315 Rutland, Vt., Mendon Road near, before and after flood of 1927 .............. Plate 6

Salinas, Calif., monthly discharge of Salinas River near . .......................

Salinas River, Calif., monthly discharge at stations on Salmon Creek, Calif., monthly discharge at station on

Sampler used in collection of silt samples.- Plate 1

San Antonio Creek, Calif., monthly discharge at stations on

San Antonio River, Calif., monthly discharge at stations on

San Benito River, Calif., monthly discharge at stations on
San Bernardino, Calif., monthly discharge of Devil Canyon Creek near........monthly discharge of Lytle Creek near

San Diego, Calif., monthly discharge of San Diego River at.

San Diego River, Calif., monthly discharge at stations on

South Fork of, monthly discharge at station on - 192

San Diego River Basin, Calif., description of _ $\quad 173$ San Dieguito River, Calif., monthly discharge at station on ............ 193-194

San Dieguito River Basin, Calif., description of - . .

San Dimas, Calif., monthly discharge of San Dimas Creek near.............. 212

San Emigdio Creek, Calif., monthly discharge at station on . . .........

San Emigdio ranch house, Calif., monthly discharge of San Emigdio Creek at. .

San Fernando, Calif., monthly discharge of Pacoima Creek near

San Gabriel River, Calif., monthly discharge at stations on

San Gabriel River, Basin, Calif., description of -

San Jacinto, Calif., monthly discharge of San Jacinto River near............. 206

San Joaquin River, Calif., description of.-- 111-112

Middle Fork of, monthly discharge at station on ........................ 141

monthly discharge at stations on ..... 138-140

North Fork of, monthly discharge at station on.

South Fork of, monthly discharge at stations on.

San Joaquin River Basin, Calif., gaging sta-

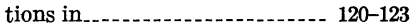

geography of . . maximum and minimum discharges in. 123-124 measurement of the flow of streams in - 101-102 monthly discharge at stations in ....... 125-168 precipitation in reports containing record of flow of streams in

San Joaquin Valley, Calif., description of - 104-105 geology of . . - 105-107

soils of

San Juan River, Utah, water of, analyses of.- 11 San Lorenzo Creek, Calif., monthly discharge at station on

San Luis Rey River, Calif., monthly discharge at stations on...-...-... 195-196

West Fork of, monthly discharge at stations on . . . . 196-197

San Luis Rey River Basin, Calif., description of - . - .

San Vicente Creek, Calif., monthly discharge at station on

Sand Meadows, Calif., monthly discharge of Helm Creek at................

Santa Ana, Calif., monthly discharge of Santa Ana River at.....................

Santa Ana River, Calif., monthly discharge at 192 stations on 
Santa Ana River Basin, Calif., description Page of . . . Basin, Calf., description

Santa Anita Creek, Calif., monthly discharge at station on

Santa Barbara, Calif., monthly discharge of Mono Creek near

monthly discharge of Santa Ynez River near

Santa Clara River, Calif., monthly discharge at station on.

Santa Clara River Basin, Calif., description of - 179-180

Santa Paula, Calif., monthly discharge of Santa Paula Creek near ..........

Santa Margarita, Calif., monthly discharge of Salinas River near............

Santa Margarita River, Calif., monthly discharge at stations on

Santa Margarita River Basin, Calif., description of.

Santa Maria, Calif., monthly discharge of Santa Maria River near ...........

Santa Maria Creek, Calif., monthly discharge at station on

Santa Maria River, Calif., monthly discharge at station on

Santa Maria River Basin, Calif., description of - - .

Santa Ynez River, Calif., monthly discharge at stations on

Santa Ynez River Basin, Calif., description of . . . 180-181

Santa Ysabel, Calif., monthly discharge of Santa Ysabel Creek near.......

Santa Ysabel Creek, Calif., monthly discharge at stations on ............ 192-193

Santee, Calif., monthly discharge of San Diego River near.

Santiago Creek, Calif., monthly discharge at

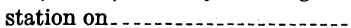

Sawpit Creek, Calif., monthly discharge at station on.

Sawyer Rapids power site, Oreg., description of

Sequoia, Calif., monthly discharge of Golden Rock ditch near....................

monthly discharge of South Fork of Tuolumne River near

Serrano \& Carpenter Canal, Calif., monthly discharge at station on ...........

Sespe, Calif., monthly discharge of Sespe Creek at and near.

Shaver, Calif., monthly discharge of Fresno Flume \& Lumber Co.'s upper and lower flumes at.

monthly discharge of Southern California Edison Co.'s flume at. ...........

Stevenson Creek at . . .................

Scottsburg lower dam site, Oreg., view of

Plate 25

Scottsburg power site, Oreg., description of - 300-302 Sierra \& San Francisco Power Co.'s canal, Calif., monthly discharge at station on
Sierra Madre, Calif., monthly discharge of Little Santa Anita Creek near... monthly discharge of Santa Anita Creek near

Sly Park, Calif., monthly discharge of Camp Creek near ................... 168

Sly Park Creek, Calif., monthly discharge at station on....................... 168

Smith Ferry power site, Oreg., description of - 294 Smith Meadow, Calif., Rancheria Creek

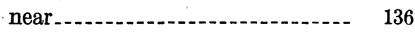

Soda Springs dam site, Oreg., view of.-..- Plate 19 Soda Springs power site, Oreg., description

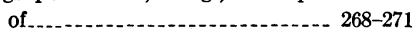

Soledad, Calif., monthly discharge of Arroyo Seco near.................... 218

South Royalton, Vt., bridge at, during flood of 1927 . . . . 10

South San Joaquin Canal, Calif., monthly discharge at station on ........... 161

South Umpqua Falls power site, Oreg., description of .................... 310

South Umpqua River, Oreg., power sites on

variation in flow of

Southern California Edison Co.'s canal, Calif., monthly discharge at stations on . . . .

Southern California Edison Co.'s flume, Calif., monthly discharge at station on

Springville, Calif., monthly discharge of Bear Creek near................ 131

monthly discharge of North Fork of Middle Fork of Tule River near....

South Fork of Middle Fork of Tule River near.........................

Stanislaus \& San Joaquin Water Co.'s canal, Calif., monthly discharge at station on.

Stanislaus River, Calif., description of......

Middle Fork of, monthly discharge at station on . .

monthly discharge at stations on...... 158-159

North Fork of, monthly discharge at station on

South Fork of, monthly discharge at station on ............ 161

Steamboat Creek, Oreg., power sites on -. 307-308 Steamboat dam site, Oreg., view of...... Plate 21 Steamboat Falls power site, Oreg., description of

'Steamboat power site, Oreg., description of. 273-275

Stearns, H. T.; with Jones, B. E., Waterpower resources of the Umpqua River and its tributaries, Oregon

Stevenson Creek, Calif., monthly discharge at station on

Stockton, Calif., monthly discharge of Calaveras River near..................

Stockton-Mokelumne Canal, Calif., monthly discharge at station on............ 
Page

Strawberry, Calif., monthly discharge of South Fork of Stanislaus River

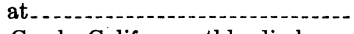

Strawberry Creek, Calif., monthly discharge at station on

Sunland, Calif., monthly discharge of $\mathrm{Tu}$ junga Creek near -

Susanna Creek, Calif., monthly discharge at station on . . . .

Sutter Creek, Calif., monthly discharge of Sutter Creek at

Sutter Creek, Calif. monthly discharge at stations on ...................... 166-167

Sweetwater Reservoir, Calif., monthly discharge of Sweetwater River at.-

Sweetwater River, Calif., monthly discharge at stations on

Sweetwater River Basin, Calif., description of

$\mathrm{T}$

Tejon House Creek, Calif., monthly discharge at station on . ..........-

Tejon ranch house, Calif., monthly discharge of Tejon House Creek at.........-

Temecula, Calif., monthly discharge of Temecula Creek near

Temescal Creek, Calif., monthly discharge at station on .

Temescal Water Co.'s diversion, Calif., monthly discharge at station on.-

Tenaya Creek, Calif., monthly discharge at station on

Thornton, Calif., monthly discharge of Mokelumne River near.

Three Rivers, Calif., monthly discharge of Kaweah River near..........-.

monthly discharge of South Fork of Kaweah River near.

Tia Juana River, Calif., monthly discharge at station on

198

206 -149 165 132 133 188

Tia Juana River Basin, Calif., description of

Tiller power site, Oreg., descript ion of ....... 312

Tilley Creek, Calif., monthly discharge of Borel Canal at................-...

Timber Knob, Calif., monthly discharge of West Fork of Granite Creek near_ 142

Toketee Falls, Oreg., view of............. Plate 20

Toketee Falls power site, Oreg., description of

Toketee Falls reservoir site, Oreg., description

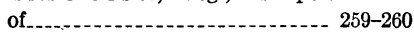

Tollhouse, Calif., monthly discharge of Big Creek near..........................

Topock, Ariz., suspended matter in Colorado River near........... 36-40, 42-44

Tres Pinos, Calif., monthly discharge of San Benito River near...............

monthly discharge of Tres Pinos Creek near.

Triunfo Creek, Calif., monthly discharge at station on ...........................

Tujunga, Calif., monthly discharge of Haines Creek near.
Tujunga Creek, Calif., monthly discharge at station on

Tulare and Kern Lake Basins, Calif., description of - . - 112

Tulare Lake, Calif., description of.......... 113-114

Tule River, Calif., description of ............ 116

monthly discharge at station on ........ 130

North Fork of Middle Fork of, monthly discharge at station on ..........- 130

South Fork of, monthly discharge at station on.

South Fork of Middle Fork of, monthly discharge at station on

Tuolumne River, Calif., description of -...... 118

Middle Fork of, monthly discharge at stations on .

monthly discharge at stations on ...... 150-152

South Fork of, monthly discharge at

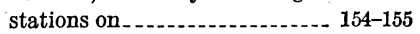

Turlock Canal, Calif., monthly discharge at station on ................ 157

Tyler Creek, Calif., monthly discharge at station on . 129

\section{U}

Umpqua River, Oreg., power sites on -...- 263-290 profile of, showing location of dam sites Plate 17 sources of information on variation in flow of ................. 235-239

Umpqua River Basin,Oreg.,annualyield and minimum flow of streams in.. 239-243

climate of

discharge measurements in . . ........... 242-243

floods in gaging stations in

geography of

geology of - ........... 232-233

hydraulic structures in, factors afiecting 234-235 map showing proposed power sites in. Plate 15 market for water power in ............. 319-320 prior water rights in requlation of flow in ..............-. 245-246 storage sites, undeveloped in summary of the report on water power, developed, in ....... 225, 260-261 water power, undeveloped, in - 225-229, 261-319

Upland, Calif., monthly discharge of San Antonio Creek near............. 207

Upper Steamboat Creek power site, Oreg., description of -

Utica Gold Mining Co.'s canal, Calif., monthly discharge at station on.-

\section{$\mathrm{V}$}

Ventura, Calif., monthly discharge of Ventura River near...-...-.....-.

Ventura River, Calif., monthly discharge at stations on - 216

Ventura River Basin, Calif., description of.- 180

Vermilion Valley, Calif., monthly discharge of Bear Creek near.......-

monthly discharge of Mono Creek near.-

Vernalis, Calif., monthly discharge of San Joaquin River near 
Villa Park, Calif., monthly discharge of Santiago Creek near. monthly discharge of Serrano \& Carpenter Canal near

Volcano, Calif., monthly discharge of Sutter Creek near.

\section{W}

Warm Creek, Calif., monthly discharge at station on

Warner Springs, Calif., monthly discharge of Carrizo Creek near

monthly discharge of Matagual Creek near.

San Luis Rey River near

Susanna Creek near near ................................

Waterbury, Vt., débris from flood of 1927 at_. Plate 5 Waterman Canyon Creek, Calif., monthly discharge at station on

Watsonville, Calif., monthly discharge of Pajaro River at

Wawona, Calif., monthly discharge of South Fork of Merced River near

West Point, Calif., monthly discharge of Middle Fork of Mokelumne River at.

monthly discharge of North Fork of Mokelumne River near

West San Pasqual ditch, Calif., monthly discharge at station on
Page 208
White River, Calif., monthly discharge at

station on of 1927 .................. Plate 10

Winchester dam site, Oreg., view of........ Plate24

Winchester power site, Oreg., description of_ 261,

Winooski, Vt., pontoon bridge at, aerial 288-290 view of

Plate 11

Winooski River, Vt., débris left by flood on- Plate 5 flood of 1927 on

Winooski Valley, Vt., Federal aid project 68 in, after flood of 1927........... Plate 13

Wolf Creek power site, Oreg., description of. 291-292

Wolf Creek reservoir site, Oreg. See Coles Valley reservoir site.

Woodbridge, Calif., monthly discharge of Mokelumne River at.

monthly discharge of Stockton-Mokelumne Canal at

Woods Creek, Calif., monthly discharge at station on

Y

Yosemite, Calif., monthly discharge of Illilouette Creek near............ 148

monthly discharge of Merced River at and near.

Tenaya Creek near ............... 148-149

Yosemite Creek at............... 149

Ysidora, Calif., monthly discharge of Santa Margarita River near........... 108 